\author{
2. To: (Receiving Organization) \\ Characterization Project \\ 5. Proj./Prog./Dept./Div.: \\ Characterization
}

\section{Originator Remarks:}

This report documents the formal design review conducted (01/27/97 to $03 / 27 / 98$ ) on portable exhausters used with Rotary Mode Core Sampling (RMCS) of Hanford waste tanks in order to meet primarily flammable gas contract requirements.

11. Receiver Remarks: $11 \mathrm{~A}$. Design Baseline Document? $\square$ Yes $\triangle$ No

\author{
3. From: (Originating Organization) \\ Characterization Engineering \\ 6. Design Authority/Design Agent/Cog. Engr.: \\ GP Janicek
}

4. Related EDT No.:

N/A

7. Purchase Order No.:

$\mathrm{N} / \mathrm{A}$

9. Equip./Component No.:

$N / A$

10. System/Bidg./Facility:

$200 \mathrm{G}$

12. Major Assm. Dwg. No.:

$\mathrm{N} / \mathrm{A}$

13. Permit/Permit Application No.:

$N / A$

14. Required Response Date:

$\mathrm{N} / \mathrm{A}$

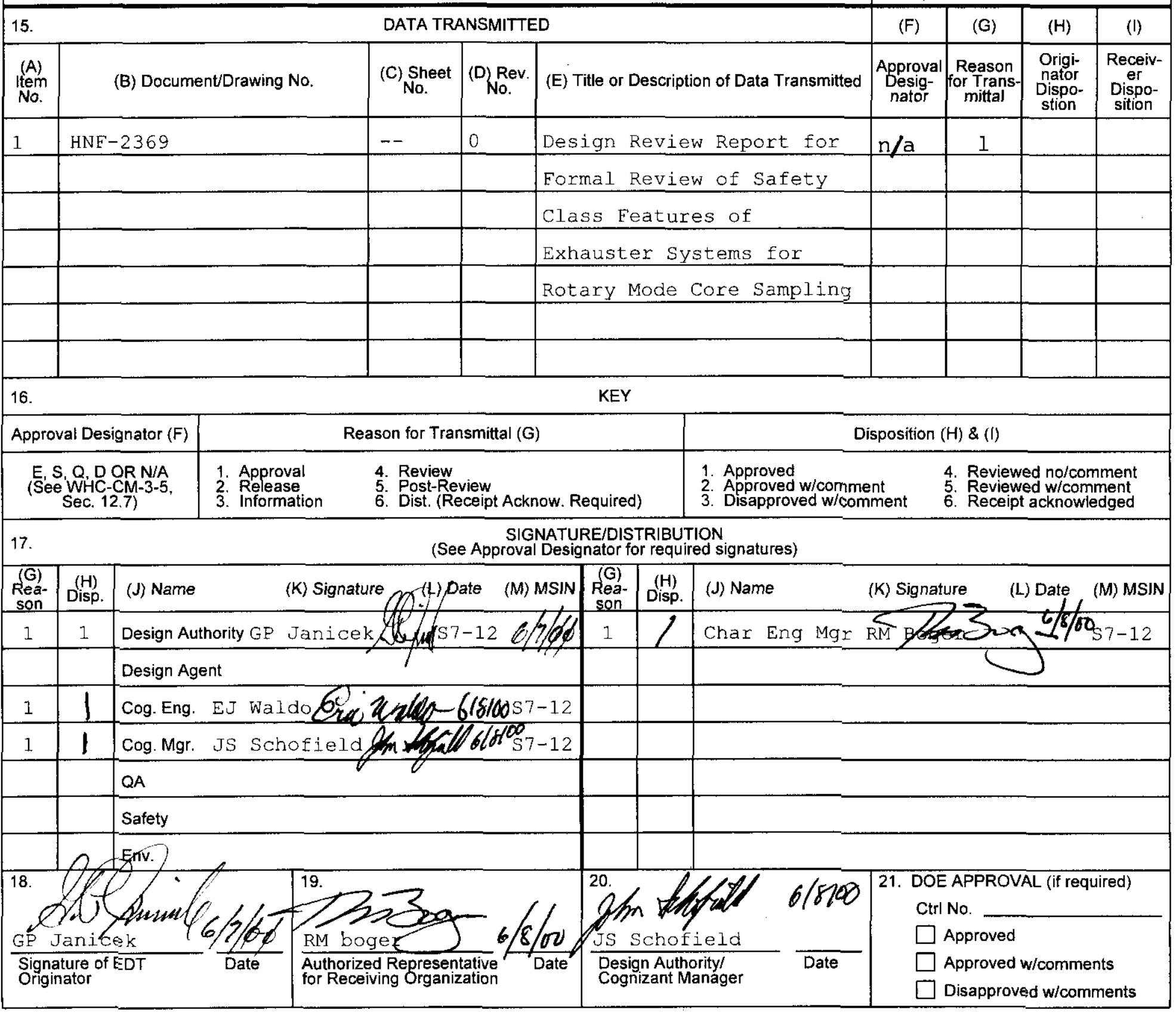




\title{
DESIGN REVIEW REPORT FOR FORMAL REVIEW OF SAFETY CLASS FEATURES OF EXHAUSTER SYSTEM FOR ROTARY MODE CORE SAMPLING
}

\author{
G. P. JANICEK \\ CH2M HILL HANFORD GROUP, INC \\ Richland, WA 99352 \\ U.S. Department of Energy Contract DE-AC06-99RL14047

$\begin{array}{lll}\text { EDT/ECN: } & 628749 & \text { UC: } 2000 \\ \text { Cost Center: } 74900 & \text { Charge Code: } 102250 \\ \text { B\&R Code: } & \text { EW3130000 } & \text { Total Pages: } \mathbf{1 7 2}\end{array}$

Key Words: Core Sampling, Exhauster, RMCS, Flammable Gas Modifications, Design Review Report

\begin{abstract}
Report documenting Formal Design Review conducted on portable exhausters used to support rotary mode core sampling of Hanford underground radioactive waste tanks with focus on Safety Class design features and control requirements for flammable gas environment operation and air discharge permitting compliance.
\end{abstract}

TRADEMARK DISCLAIMER. Reference herein to any specific commercial product, process, or service by trade name, trademark, manufacturer, or otherwise, does not necessarily constitute or imply its endorsement, recommendation, or favoring by the United States Government or any agency thereof or its contractors or subcontractors.

Printed in the United States of America. To obtain copies of this document, contact: Document Control Services, P.O. Box 950, Mailstop H6-08, Richland WA 99352, Phone (509) 372-2420; Fax (509) 376-4989.
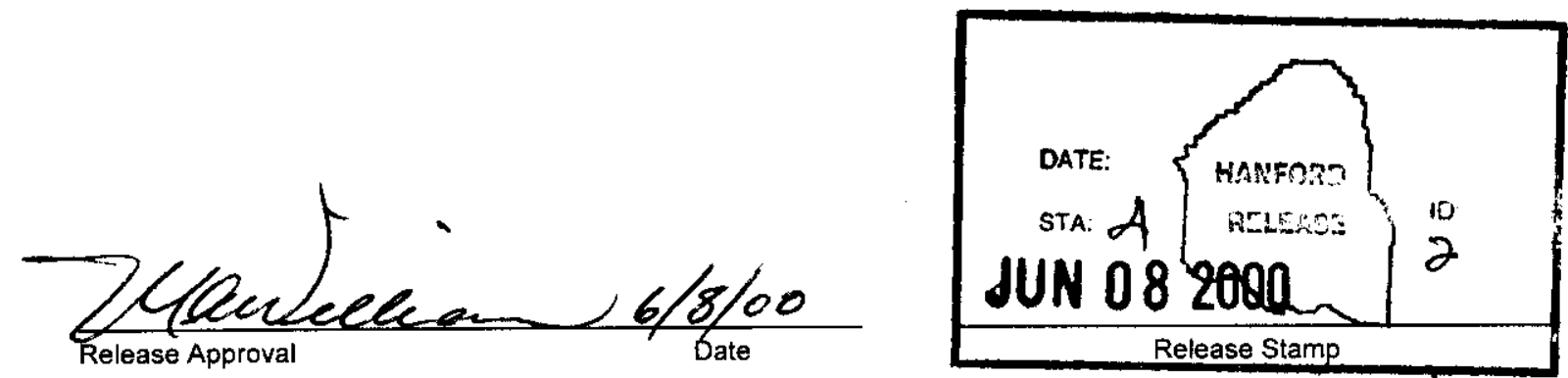

Approved For Public Release 
G. P. Janicek

CH2M HILL Hanford Group, Inc.

Richland, WA

June 2000 


\section{Table of Contents}

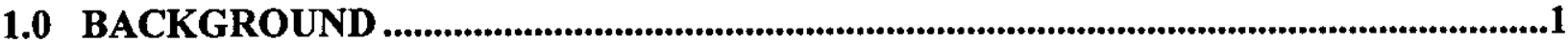

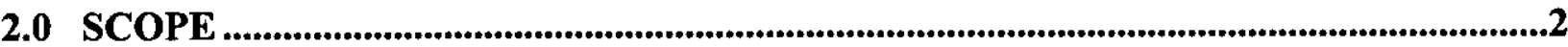

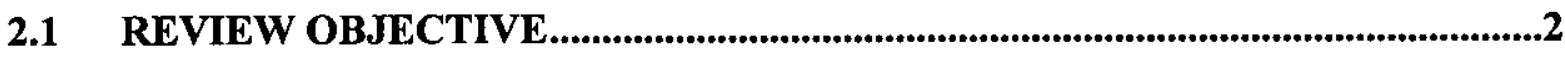

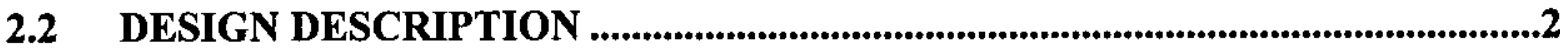

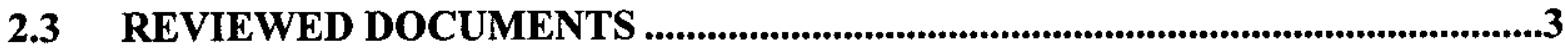

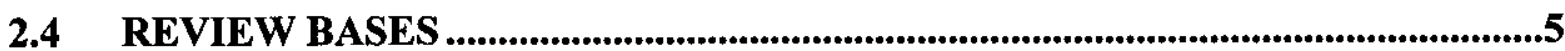

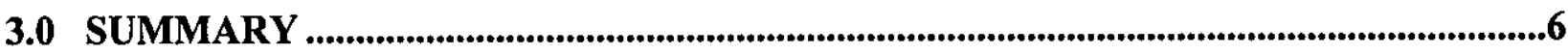

3.1 REVIEW DESCRIPTION

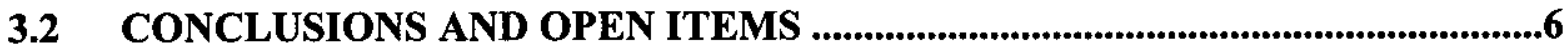

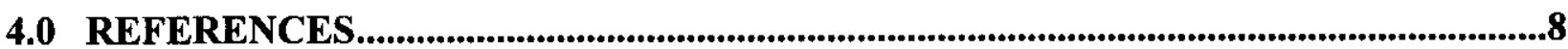

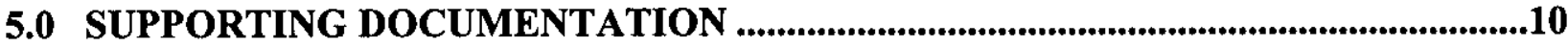

5.1 DRAFT DESIGN COMPLIANCE MATRIX (DESIGN REVIEW CHECKLIST) ....................................................................................... 1

5.2 DRAFT DESIGN COMPLIANCE MATRIX PUNCHLIST W/CLOSURE

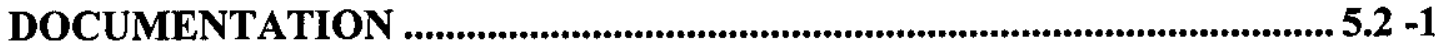

5.3 DESIGN REVIEW COMMITTEE MEMBERSHIP/CHARTER................. 5.3 - 1

5.4 REVIEW COMMENT RECORD (RCR) FORMS ....................................... 5.4 - 1

5.5 DESIGN REVIEW COMMITTEE MEETING AGENDAS........................ 5.5 - 1

5.6 DESIGN REVIEW COMMITTEE MEETING MINUTES............................ 5.6 - 1

5.7 DESIGN REVIEW CLOSURE CORRESPONDENCE W/BACKUP DATA5.7 -1 
HNF-2369

Rev. 0

\section{DESIGN REVIEW REPORT FOR FORMAL REVIEW OF SAFETY CLASS FEATURES OF EXHAUSTER SYSTEM FOR ROTARY MODE CORE SAMPLING}

\subsection{BACKGROUND}

This report documents the completion of a formal design review conducted on the portable exhauster(s) used to support Rotary Mode Core Sampling (RMCS) operations in Hanford waste tanks. The review commenced on January 21,1997 , and was formally closed, in its entirety, on March 27, 1998. A number of actions occurred between these dates that changed the scope and bases of the review, resulting in the extended duration of the review and the need to document a certain portion of this formal design review in a separate report (Corbett 1997).

The review initially focused on "selected modifications" of the exhauster system being implemented in order to comply with waste tank flammable gas control requirements then governed by the RMCS system-specific safety basis (WHC,1996a). These "selected modifications" had previously undergone a formal design review in 1996 (WHC 1996b), but because of a newly discovered safety system inadequacy in the design (documented in Thomson 1997), the manager of Characterization Engineering requested that a second, formal design review, be performed. This second review covered six separate review packages, DRC-97-001 through DRC-97-006. Except for DRC-97-004 and -006, all packages were reviewed, closed, and documented in Corbett 1997. This report documents formal design review closure on review package DRC-97-004 and its five supplementary packages, DRC-97-004a through DRC-97004e, as well as DRC-97-006.

Review package DRC-97-004 was first distributed for review at a design review briefing on February 3, 1997. Initially, the scope of this package included exhauster adjunct equipment designed to attach to a tank riser (to which the exhauster itself is attached), monitor flammable gas parameters, and cause shutdown of sampling operations if certain parameter limits were exceeded. This adjunct equipment was dubbed the Hydrogen Exhauster Interlock System (HEIS). Shortly thereafter, by request of the Manager of Characterization Engineering (R E. Raymond), the scope of the review was expanded to include a re-review of all Safety Class (SC) structures, systems, and components (SSCs) associated with the complete exhauster system. In March 1997, before the review was complete, the Characterization Project decided to replace (in anticipation of actual replacement approved in August 1997) the flammable gas controls derived from the original, and primary, Authorization Basis (AB) document for RMCS (WHC 1996a) with those derived from the Justification for Continuing Operation (JCO) being used to govern the remainder of tank farm operations (LMHC 1997a). The net result of this decision was twofold: (1) it negated the entire review scope documented in the earlier design review report (Corbett, 1997), and the adjunct equipment portion (original HEIS scope) of review package DRC-97-004, as well as all of DRC-97-006, and (2) it necessitated that additional modifications be made to the exhauster skid itself. Formal review of the resultant remaining and added review scope of the exhauster system was completed in August 1997 and the formal 
design review was officially (and initially) declared closed. However, the review had to be extended when it was determined that the current Notice of Construction (NOC) (DOE/RL 1995) for the portable exhauster systems was being revised by the Washington State Department of Health (WDOH), imposing additional requirements (WDOH 1997). Thus it wasn't until March 1998, concurrent with final NOC approval by WDOH, that open items remaining from the extended review and a reconciliation with changes still being made to the exhauster system allowed definitive closure of the formal design review.

\section{$2.0 \quad$ SCOPE}

\subsection{REVIEW OBJECTIVE}

The commissioned objective of the formal design review was to perform design verification of all exhauster system SC SSCs. This included a re-verification of original and remaining (unmodified) SC SSCs as well as those SC SSCs added during exhauster modifications. The Design Review Committee (DRC), of its own accord, elected to comment on and require satisfactory disposition of other technical inadequacies, of an obvious nature, discovered during the review.

\subsection{DESIGN DESCRIPTION}

The RMCS exhauster is an electrically operated, portable, single train, skid-mounted unit used in conjunction with rotary mode core sampling of passively vented, single-shell waste tanks. Its primary purpose is to maintain the waste tank internal airspace at or below local atmospheric pressure by overcoming the purge gas volumetric flow being added to the tank as a necessary part of core sampling operations. Secondarily, it must comply with other requirements and controls. Most notable, with respect to this review, are those that cause portions of the exhauster to be classified as SC. The exhauster is connected to a riser of the waste tank by a flexible duct. Tank vapors and gases are drawn from the tank, through the flexible duct, then through the exhauster train by an inline, direct-driven, $200 \mathrm{scfm}$, exhaust fan before being vented to the atmosphere through a 4-inch diameter, 15 foot high exhaust stack. The exhauster train between the fan and the flexible duct consists of a heater section, a prefilter section, and a high efficiency particulate air (HEPA) filter set of sections. The heater section is a tubular heat exchanger supplied with an electrically heated and circulated glycol/water solution. The purpose of the heater section is to maintain the airstream temperature above its dewpoint sufficient to prevent downstream condensation of airstream-entrained water vapor. The purpose of the prefilter section is to filter the airstream of gross particulate matter and protect the HEPA filters immediately downstream. The HEPA filter set of sections consists of two stages of HEPAs in series, with each stage separately testable (includes a test section) and monitored for differential pressure across the filter media. The purpose of the HEPAs is to ensure against release of unacceptable radiological emissions to the immediate atmosphere/environment.

Exhauster operating conditions are monitored and recorded on a datalogger located in the exhauster instrument/control cabinet. The exhauster is designed to shut down automatically when waste tank pressure falls below -3 inches water gage, when exhauster stack flow rises above $250 \mathrm{scfm}$ or falls below $150 \mathrm{scfm}$, or when differential pressure across the HEPA filter 
section exceeds a predetermined value. The exhauster is equipped with an electrical interlock circuit that will cause shutdown of RMCS truck (with purge gas) operation if the exhauster itself shuts down.

\subsection{REVIEWED DOCUMENTS}

The following design review packages, with associated reference documentation, were reviewed and approved (as applicable), as part of the formal design review [Note: documents preceded by an asterisk are those negated by the switch in the $\mathrm{AB}$ for flammable gas controls, and thus, are not representative of the exhauster system final configuration:

DRC-97-004 containing the following released drawings and released ECNs and predicated on the initial, and primary, AB document (WHC 1996a) for flammable gas waste tank operation:

*H-14-100519, 520, sheets 1-3 each, (9/96 released drawings), FGAS Exhauster Interlock Elementary Diagram, for carts 2205 and 2206, respectively.

${ }^{*} \mathrm{H}-14-100521$, sheets 1-16, (9/96 released drawing), FGAS Exhauster Interlock Cart 2205/2206 Assemblies.

${ }^{*} \mathrm{H}-14-100522$, sheets 1-4, (9/96 released drawing), FGAS Exhauster Cable Arrangement and Assemblies.

${ }^{*} \mathrm{H}-14-100523$, sheets 1-3, (9/96 released drawing), Combination Sampler Spool Piece Installation.

${ }^{*} \mathrm{H}-14-100524$, sheets 1-9, (9/96 released drawing), Combination Sampler Spool Piece (Assembly).

${ }^{*} \mathrm{H}-14-100530$, sheets 1-5, (9/96 released drawing), FGAS Exhauster Interlock Power Distribution Skid.

${ }^{*} \mathrm{H}-14-100531,532$, sheets 1-3 each, (9/96 released drawings), Exhauster Interlock Cart Interconnection Diagram, for carts 2205 and 2206; respectively.

H-14-100739, sheets 1-2, (9/96 released drawing), RMCS Exhauster Heater Assembly. ${ }^{*} \mathrm{H}-14-100741$, sheet 1/1, (9/96 released drawing), RMCS FGAS Exhauster Regulator Assembly.

H-14-100742, sheets 1-3, (9/96 released drawing), Breather Vent Stack Assembly.

${ }^{*} \mathrm{H}-14-100771$, sheet 1/1, FGAS Exhauster Interlock Loop Diagram.

H-2-821455, sheets 1-5, (6/95 released drawing), RMCS Exhauster Assembly II.

H-2-821456, sheets 1-2, (6/95 released drawing) RMCS Exhauster Skid Assembly II.

*ECN 636516, (released 9/20/96), to drawings H-14-100519, 520, 521, 531, 532.

${ }^{*}$ ECN 636576, (released 10/22/96), to drawings H-14-100523, 524.

ECN 628744, (released 5/31/96), to drawing H-2-821455.

ECN 630002, (released 11/12/96), to drawing H-2-821455.

ECN 632390, (released 5/31/96), to drawings H-14-030122.

ECN 632406, (released 5/31/96), to drawing H-2-821456.

ECN 634030, (released 7/17/96), to drawings H-14-030122, H-2-821455, 456.

ECN 634031, (released 9/20/96), to drawings H-14-030122, H-2-821455.

ECN 634083, (released 8/12/96), to drawing H-14-030122.

ECN 636502, (released 8/29/96), to drawing H-2-821456. 
ECN 636503, (released 9/20/96), to drawing H-2-821455.

ECN 636513, (released 9/18/96), to drawing H-14-100740.

ECN 636515, (released 12/4/96), to drawing H-14-100740.

ECN 636940, (released 12/4/96), to drawing H-14-100740.

ECN 639170, (released 12/20/96), to drawing H-14-100742.

DRC-97-006 containing the initial draft ECN resulting from DRC-97-004:

*ECN 631342, (drafted 3/3/97), to drawings H-14-100519, 520, 521, 523, 524, 531, 532, 771, and H-14-030122. Added flammable gas sampling vacuum pump automatic shutdown capability. [Note: this ECN was subsequently cancelled.]

DRC-97-004a containing only those documents remaining from DRC-97-004 after the switch to the JCO as the Authorization Basis for flammable gas waste tank operation:

H-14-100739, sheets 1-2, (9/96 released drawing), RMCS Exhauster Heater Assembly. H-14-100741, sheet 1/1, (9/96 released drawing), RMCS FGAS Exhauster Regulator Assembly.

H-14-100742, sheets 1-3, (9/96 released drawing), Breather Vent Stack Assembly. H-2-821455, sheets 1-5, (6/95 released drawing), RMCS Exhauster Assembly II. H-2-821456, sheets 1-2, (6/95 released drawing) RMCS Exhauster Skid Assembly II. ECN 628744, (released 5/31/96), to drawing H-2-821455.

ECN 630002, (released 11/12/96), to drawing H-2-821455.

ECN 632390, (released 5/31/96), to drawings H-14-030122.

ECN 632406, (released 5/31/96), to drawing H-2-821456.

ECN 634030, (released 7/17/96), to drawings H-14-030122, H-2-821455, 456.

ECN 634031, (released 9/20/96), to drawings H-14-030122, H-2-821455.

ECN 634083, (released 8/12/96), to drawing H-14-030122.

ECN 636502, (released 8/29/96), to drawing H-2-821456.

ECN 636503, (released 9/20/96), to drawing H-2-821455.

ECN 636513, (released 9/18/96), to drawing H-14-100740.

ECN 636515, (released 12/4/96), to drawing H-14-100740.

ECN 636940, (released 12/4/96), to drawing H-14-100740.

ECN 639170, (released 12/20/96), to drawing H-14-100742.

DRC-97-004b containing new ECNs designed to allow RMCS flammable gas waste tank operation with active ventilation systems as opposed to using a portable exhauster system:

ECN 642940, (released 7/15/97), to drawing H-2-690071, ties in pressure switch shutdown to RMCS truck control console. [Note: this was initially issued as a temporary ECN and was then made a permanent change by ECN 640484 released 3/4/98.] ECN 642941, (released 7/15/97), to drawing H-2-690127, adds a portable pressure switch to be used in lieu of portable exhauster shutdown capabilities when deployed in tanks with active ventilation. 
HNF-2369

Rev. 0

DRC-97-004c containing new ECNs modifying exhauster due to new criteria:

ECN 631344, (released 9/18/97), to drawing H-2-821455, adds 2nd stage testable HEPA unit and exhauster emissions monitoring capability per revised air operating permit. ECN 631345, (released 9/17/97), to drawing H-2-821456, modifies exhauster skid and relocates heater.

ECN 631346, (released 9/18/97), to drawing 821455, details addition of differential pressure monitoring equipment to HEPA train.

DRC-97-004d containing new ECN to address additional improvements for ECN 642941 reviewed by DRC-97-004b:

ECN 640442, (replaces draft ECN 642911 for review), (released 9/16/97), to drawing H-2-690127, adds a weather resistant pressure switch assembly.

DRC-97-004e containing new ECN to address "major stack" designation of exhauster air discharge stack:

ECN 642928, (released 11/14/97), to drawings H-2-821455, 828083, 829086, 829087, 829108,829110 , adds beta particle continuous air monitor.

\subsection{REVIEW BASES}

The initial bases for conducting the formal design review (predicated on using the HEIS) were requirements derived from the then current revisions of; the Functional Design Criteria, with outstanding ECNs (WHC 1995a); the Safety Analysis document, Rev. 0-a, (WHC, 1996a); and the governing Safety Equipment List (SEL) (Smalley 1996), itself derived from the same Safety Analysis, and the JCO. Initially design review checklists were generated by the DRC modeled after the generic format for such a checklist given in the Engineering Practices Guidelines, WHC-IP-1026, EPG-4-1 (see Section 5.1). Subsequently, and for finally completing the review, the DRC developed an exhauster system-specific Design Compliance Matrix (DCM) which took the place of the generic checklist. The concept of a DCM was born out of an internal review of Characterization Engineering which was critical of the lack of formal documentation of requirements for existing equipment when performing design modification work to that equipment. Characterization took the concept a step further in formatting the DCM to include "design requirements," "design solution," and "design verification" sections. The DRC reviewed the documents listed above, as well as other criteria documents (LMHC 1997b) (LMHC 1995b), that represented the full exhauster system design review scope and gleaned from them the requirements used to populate the "design requirements" section of the DCM. The DRC then used this listing to verify that the "design solution," as presented, fulfilled the requirements. It should be noted that the DCM was a comprehensive listing, but that only those requirements specific to SC SSCs were within the DRC's purview. The final DCM used for the design review is included in Section 5.1 of this report. It should be noted, also, that this activity was itself a review of the DCM that was subsequently approved and issued as a Supporting Document " 1. (Rev. 0) in December 1997 (LMHC 1997c). 


\subsection{SUMMARY}

\subsection{REVIEW DESCRIPTION}

The DRC was initially composed of seven members. The DRC chairman was appointed by the Characterization Engineering Manager and the Chairman selected the remaining six members in accordance with TWRS procedure HNF-PRO-445, "Design Verification Requirements". Over the time period involved for the review, but at different times, two members (Corbett, Frater) left the DRC because of other opportunities, and three members (Frater, Kriskovich, Dormant) were added. The DRC members and their areas of responsibility are identified in Section 5.3 documentation.

Design review meetings (briefings, comment input, comment resolution, checklist (DCM) generation, etc.) were held as required and included issuance of agendas and meeting minutes, which are included in Sections 5.5 and 5.6 documentation, respectively.

The DRC, as a body, conducted a review of the material presented in Section 2.3 over twenty meetings. The first meeting was held on February 3, 1997, and the last on October 23, 1997. Additional one-on-one meetings were held between the Chairman and certain DRC members to close RCR comments and open items or to perform reconciliation checks.

A Flammable Gas Equipment Advisory Board (FGEAB) had been established to rule on adherence to flammable gas requirements resulting from JCO controls, or equivalency in meeting those requirements. A ruling on certain components of the exhauster system meeting those requirements was given by the FGEAB and is documented in a report, FGEAB-97-029, included in Section 5.7 of this report.

\subsection{CONCLUSIONS AND OPEN ITEMS}

The formal design review was initially thought closed, except for four punchlist items, and a DSI to this effect (see Section 5.7), was sent to D.H. Shuford on August 8, 1997.

Punchlist items 1 and 4 required reconciliation between the draft DCM (used to conduct the design review) and the final, approved version. This was accomplished by subsequent review, and issuance, of the DCM in December 1997 (see Section 5.2).

Item 3 required reconciliation between the draft $\mathrm{DCM}$ and its requirements source documents (FDC, SEL, and AB transition). DRC assignments in this regard were made at a meeting held on August 14, 1997, and closure was obtained during a series of subsequent meetings held shortly thereafter. However, formal closure could not be stated until FDC revision (LMHC 1997d), SEL revision (LMHC 1998), and the DCM was approved and issued (as was necessary for items 1 and 4).

Item 2 required compliance with both the DCM and the NOC. It was the NOC that drove the design review activity to reopen. The NOC was formally approved within this same time frame, but the WDOH added 18 new conditions. One of these conditions stipulated upgrading the 
exhauster to a "major stack" designation. This necessitated additional modifications to the exhauster. ECN 642928 for the modifications was reviewed at a DRC meeting on October 23, 1997, and approved and released on November 14, 1997 (see Section 5.7). The actual modifications were work completed on March 5, 1998.

The design review was finally declared closed on March 27,1998 , in a DSI to D. H. Shuford (see Section 5.7). A remaining part of punchlist item 3 , ensuring that the exhauster operating procedure incorporates the actual controls called for by the $\mathrm{AB}$, was closed by transferring it to the exhauster startup readiness checklist. 


\subsection{REFERENCES}

Corbett, J. E., 1997, "Design Review Report for Modifications to RMCS Safety Class Equipment," HNF-SD-WM-DRR-062, Rev. 0, Lockheed Martin Hanford Corporation, Richland, Washington.

DOE/RL 1995, "Radioactive Air Emissions Program NOC for the Rotary Mode Core-Sampling Systems Three and Four," DOE/RL-94-118, Rev. 1, U.S. Department of Energy, Richland Operations Office, Richland, Washington.

LMHC 1997a, "Flammable Gas/Slurry Growth Unreviewed Safety Question: Justification for Continued Operation of the Tank Farms at the Hanford Site," WHC-SD-WM-JCO-007, Rev. 1, Lockheed Martin Hanford Corporation, Richland, Washington.

LMHC 1997b, "Functional Design Criteria for the Rotary Mode Core Sampling Exhauster," HNF-SD-WM-FDC-025, Rev. 1, Lockheed Martin Hanford Corporation, Richland, Washington.

LMHC 1997c, "Baseline Design Compliance Matrix for the RMCS System," HNF-SD-WM-CR-062, Rev. 0, Lockheed Martin Hanford Corporation, Richland, Washington.

LMHC 1997d, "Functional Design Criteria for the Rotary Mode Core Sampling Exhauster," HNF-SD-WM-FDC-025, Rev. 2, Lockheed Martin Hanford Corporation, Richland, Washington.

LMHC 1998, "A Safety Equipment List for Rotary Mode Core Sampling Systems Operation in Single Shell Flammable Gas Tanks," HNF-SD-WM-SEL-044, Rev. 1, Lockheed Martin Hanford Corporation, Richland, Washington.

Smalley, J. L., 1996, "Rotary Mode Core Sampling Safety Equipment List," WHC-SD-WM-FDC-032, Rev. 1 (with ECNs 636964 and 636966), Lockheed Martin Hanford Corporation, Richland, Washington.

Thomson, J. D. 1997, "Review of Characterization Engineering Hydrogen Exhauster Interlock System Design Process," Letter Report for R. E. Raymond, Anttonen Lucas Associates, Inc., Richland, Washington.

WDOH 1997, Letter, A. W. Conklin to J. E. Rasmussen (DOR/RL), "Notice of Construction, DOE/RL-94-118, Rev. 1," \#AIR 97-901, dated September 3, 1997, State of Washington Department of Health, Olympia, Washington. 
WHC 1995a, "Flammable Gas Detection and Shutdown System Functional Design Criteria," WHC-SD-WM-FDC-045, Rev. 0, Westinghouse Hanford Company, Richland, Washington.

WHC 1995b, "Functional Design Criteria for Core Sampling in Flammable Gas Watchlist Tanks," WHC-SD-WM-FDC-048, Rev. 0, Westinghouse Hanford Company, Richland, Washington.

WHC 1996a, "A Safety Assessment of Rotary-Mode Core Sampling in Flammable-Gas SingleShell Tanks: Hanford Site, Richland, Washington," WHC-SD-WM-SAD-035, Rev. 0a, Westinghouse Hanford Company, Richland, Washington.

WHC 1996b, "Final Design Review Report for the RMCS Flammable Gas Detector Interlock," WHC-SD-WM-DRR-051, Rev. 0, Westinghouse Hanford Company, Richland, Washington. 
HNF-2369

Rev. 0

\subsection{SUPPORTING DOCUMENTATION}

The remainder of this report, Sections 5.1 through 5.7, provides supporting documentation to the formal design review and is referenced in the foregoing body of the report. 
HNF-2369

Rev. 0

5.1 DRAFT DESIGN COMPLIANCE MATRIX (DESIGN REVIEW CHECKLIST)

Page $5.1-1$ 
HNF-2369

Rev. 0

DON'T SAY IT -..- Write It!

TO:

JM Dormant

GT Frater

GP Janicek

TD Jarecki

JR Kriskovich

ML McEiroy

NJ Milliken

JA Ranschau

CC Scaief
DATE: $08 / 04 / 97$

FROM: GP Janicek

Telephone: $376-2225$
$\mathrm{Kg}-46$

$57-12$

S7-03

Rl-56

S7-07

$\mathrm{R} 1-43$

S7 -07

RI-56

cc: RE Raymond S7-12

SUBJECT: Exhauster Design Compliance Matrix

Attached is the subject DCM for which we are to complete the verification section. Recall that the scope of our review as the Design Review Committee (DRC) was to encompass all Safety SSCs.

Please do two things preparatory to our Thursday meeting $(08 / 07 / 97)$ to assist coming to closure on the DCM verification.

1. Review the previous copy of the DCM you have, which was based on the old authorization basis, and be prepared to verify the same particular, or category of, requirements for which you were assigned responsibility previously.

2. Review your new RCR comments, which were re-generated from your prior RCR comments, subsequently dispositioned, and then approved by you based on an understanding (verbally conveyed) of what the new authorization basis was to be, to see if they are still valid or whether any changes are necessitated.

Assuming all other supporting activities go as planned, e.g., $A B$ amendment process, the DCM verification will close our design review of the Exhauster system and system modifications for flammable gas operation.

Need anything? Let me know.

Thanks,

George 
HNF-2369

Rev. 0

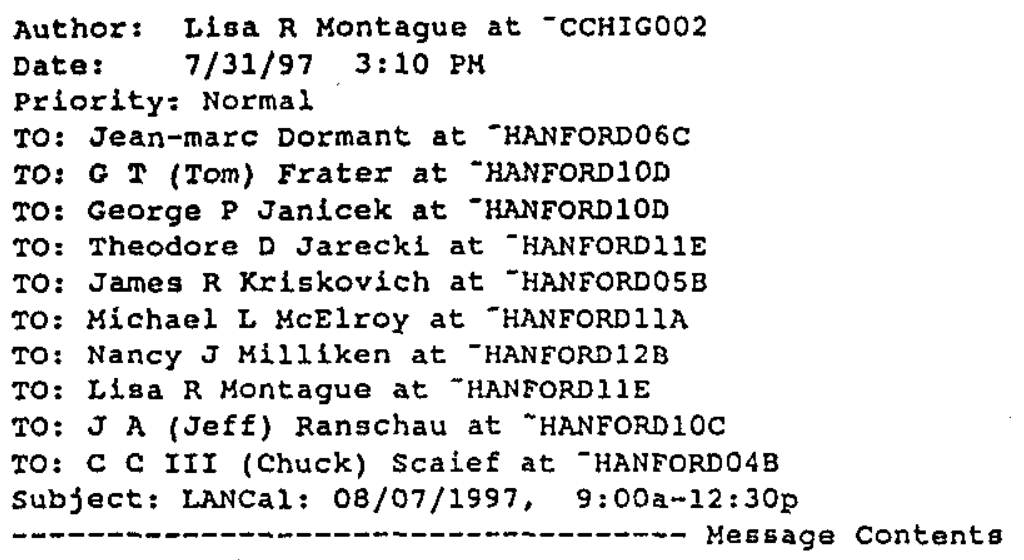

Meeting Time: Thursday August 7, 1997, 9:00am-12:30pm

Description: DESIGN REVIEW COMMITTEE MTG FOR EXHAUSTER

DESIGN COMPLIANCE MATRIX VERIFICATION

2704HV/G108A POC:George 6-2225/Lisa 3-5508

Scheduled by: Montague, Lisa R

July 31, 1997, 3:09pm

Attendees: Dormant, Jean-marc

Frater, G T (Tom)

Janicek, George $P$

Jarecki, Theodore $D$

Kriskovich, James $R$

MeElroy, Michael L

Milliken, wancy J

Montague, Lisa $R$

Ranechau, J A (Jeff)

Scaief, C C III (Chuck)

Page 5.1-3 
DON'T SAY IT ... Write It!

TO:

GP Janicek

$57-12$

cc:

$57-12$
DATE: August 4, 1997

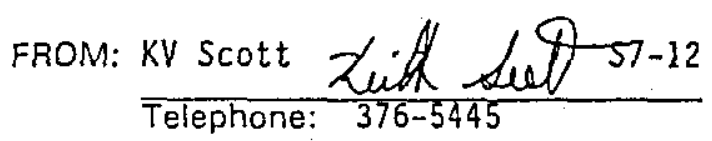

S7-12

$57-12$

S7-12

SUBJECT: RMCS EXHAUSTER DESIGN COMPLIANCE MATRIX

Attached please find 10 copies of the subject Design Compliance Hatrix (DCM) for distribution to the Design Review Team.

Please note that these tables will become a part of an overall DCH for the RMCS system. The other sections for tnis wili roilow, but as agreed, this exhauster portion is requiicus to complete the Design Review for deployment to the field.

If you have any questions on this please call me on 376-5445. 
HNF-2369

Rev. 0

HNF-SD-WHS-CR-062, Rev. 0

\section{TABLE 1} BASIC FUNCTIONAL CHARACTERISTICS AND CONSTRAINTS FOR THE RMCS EXHAUSTER
DESIGN

है

FUNCTIONAL CHARACTERISTICS

Performance and External Interface Requirements

- The exhauster shall maintain the tank vapor space below atmospheric pressure during rotary mode core sampling by removing potentially flarmable vapor while the drill string nitrogen puroe is adding nitrogen to the tank

- The exhauster shall be moved from tank to tank to support RMCS operations

- The exhauster shall function in the Kanford climate

- The exhauster materials shall be compatible with the Hanford environnent and tank vapor stream

The exhauster shall interface with the RMCS truck (iruck:s 3 and 4 ), a power supply, the tank riser, and aerosol testing equipment

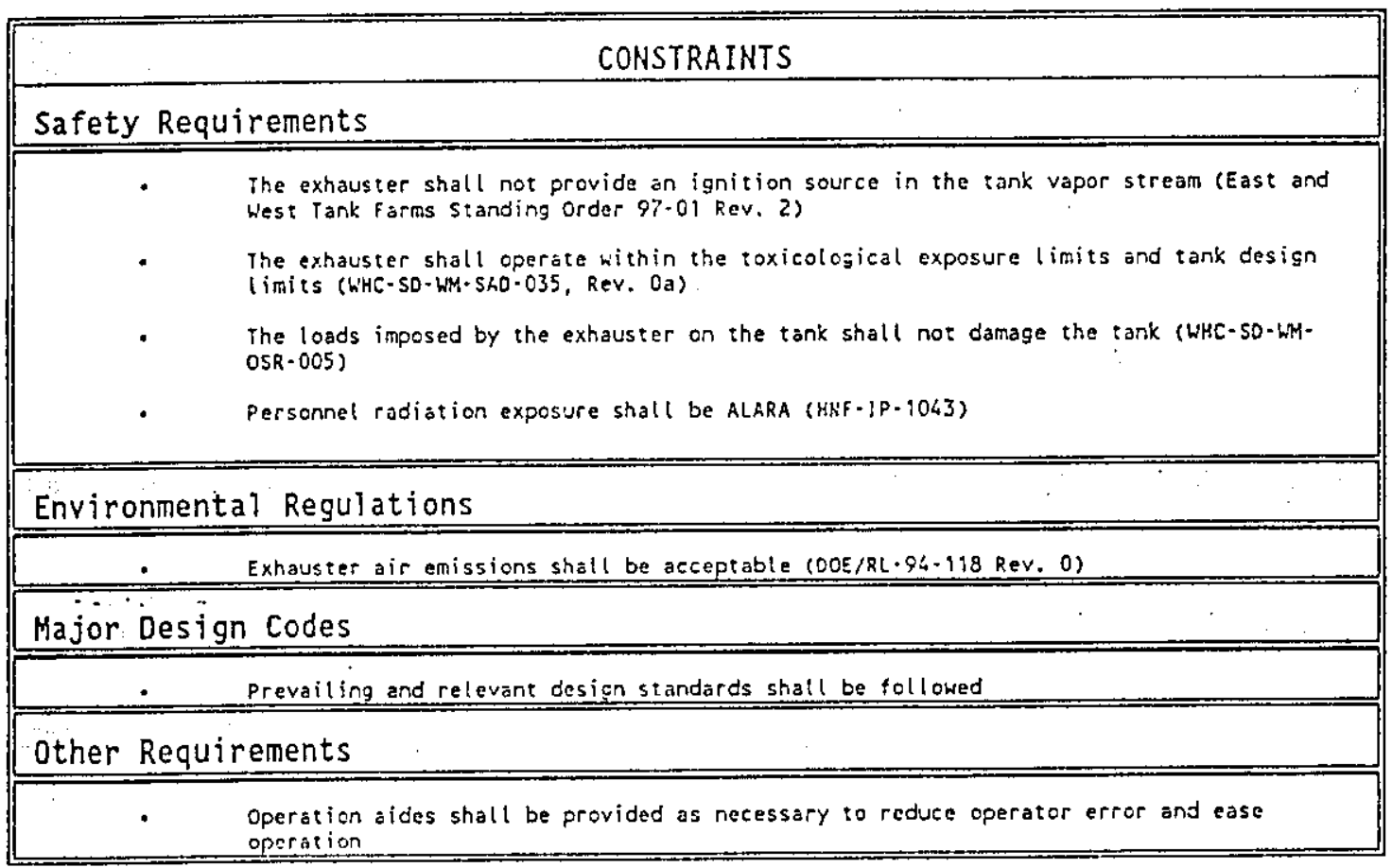

Page 8

Page 5.1 - 5 


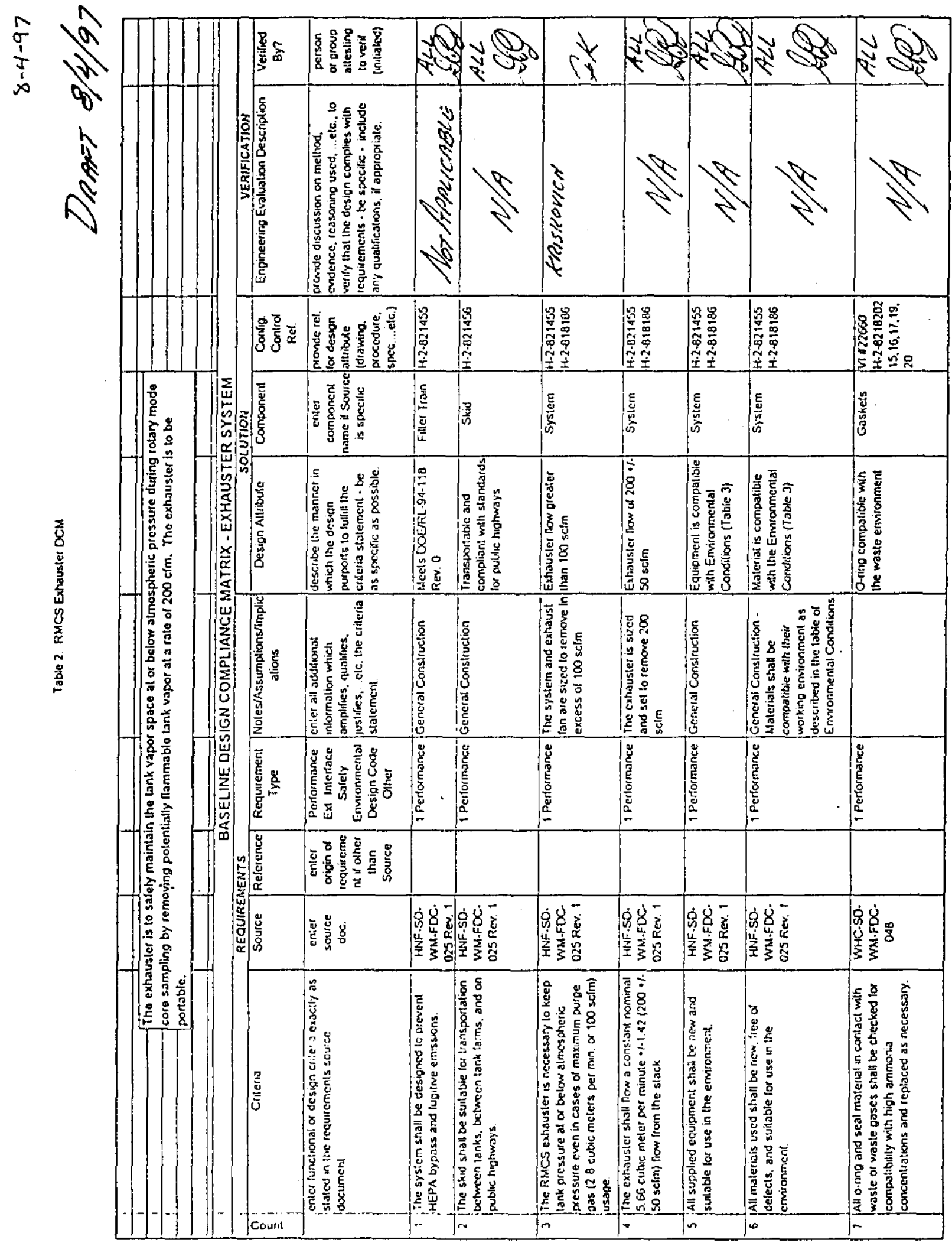

Page 5.1- 6 
HNF-2369

Rev. 0

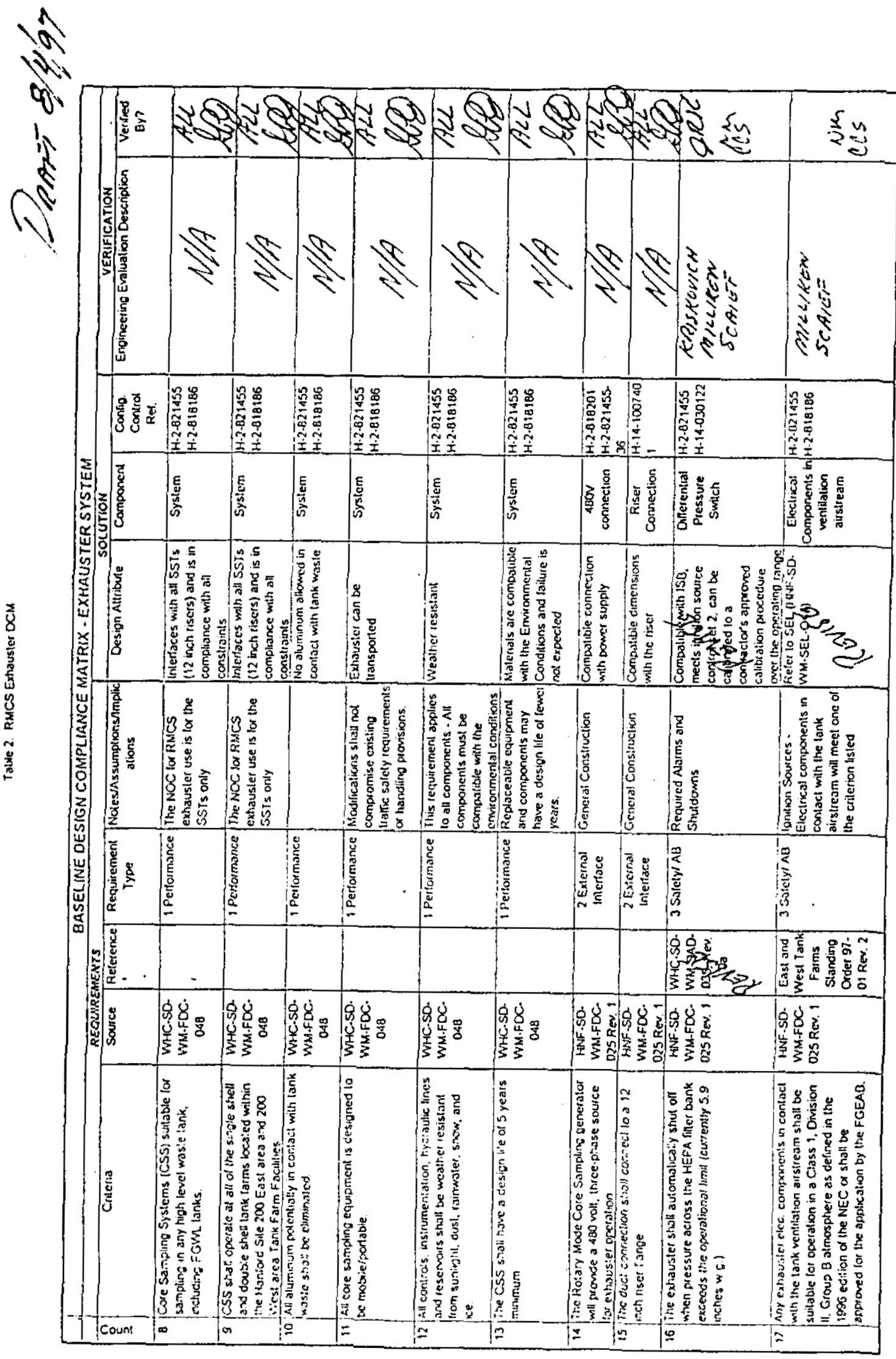

Page $5.1-7$ 


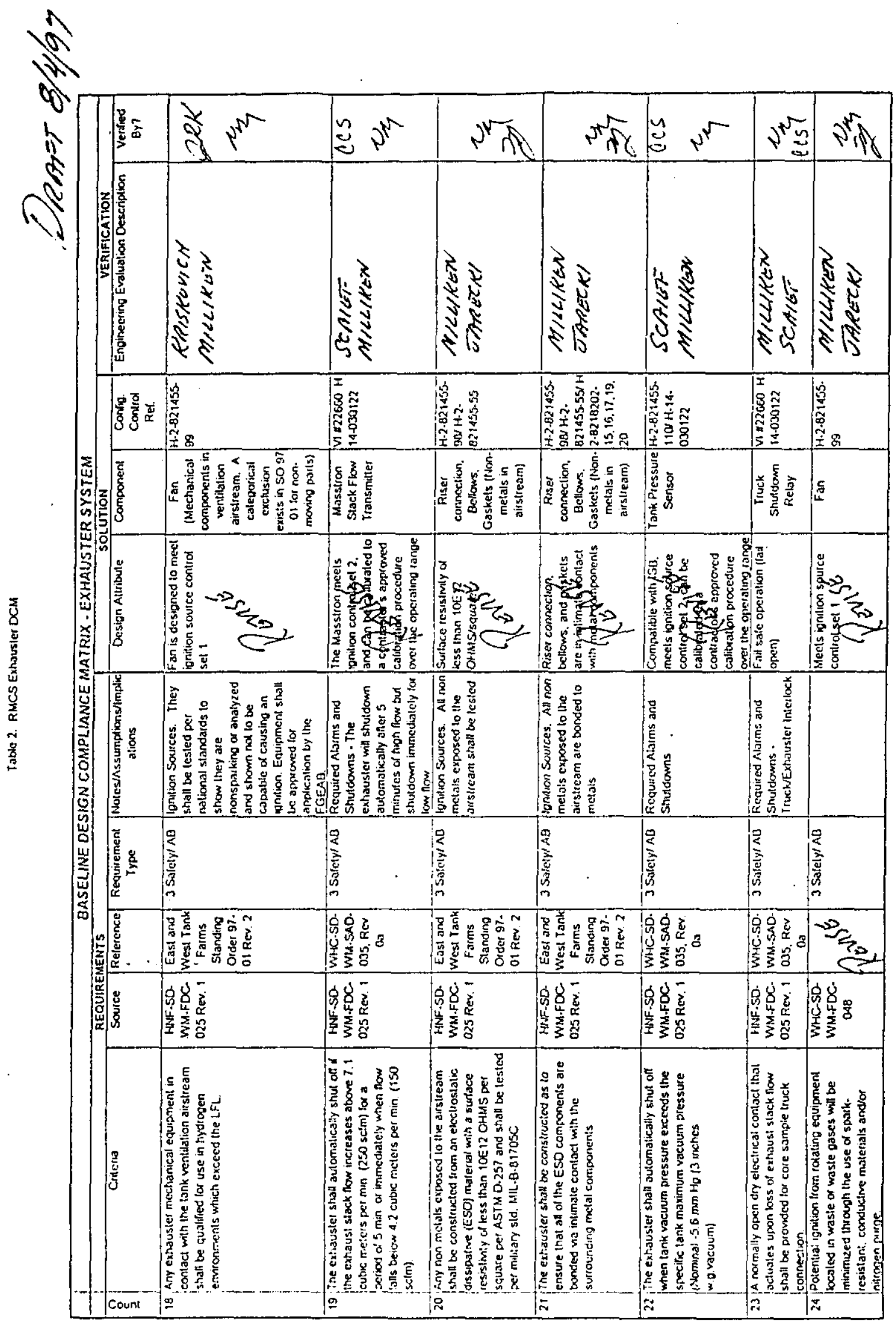

Page 5.1- 8 


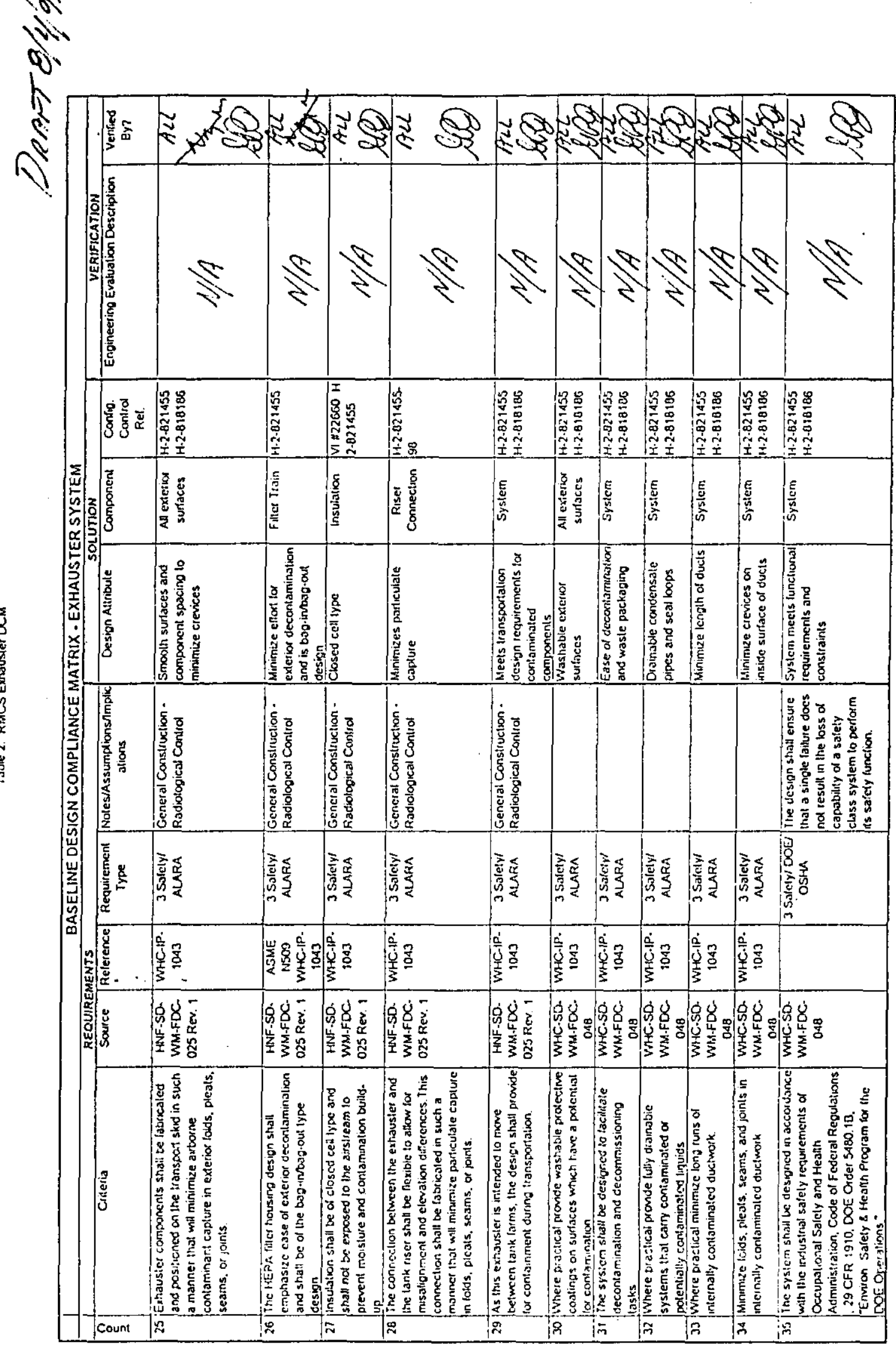

Page 5.1 - 9 


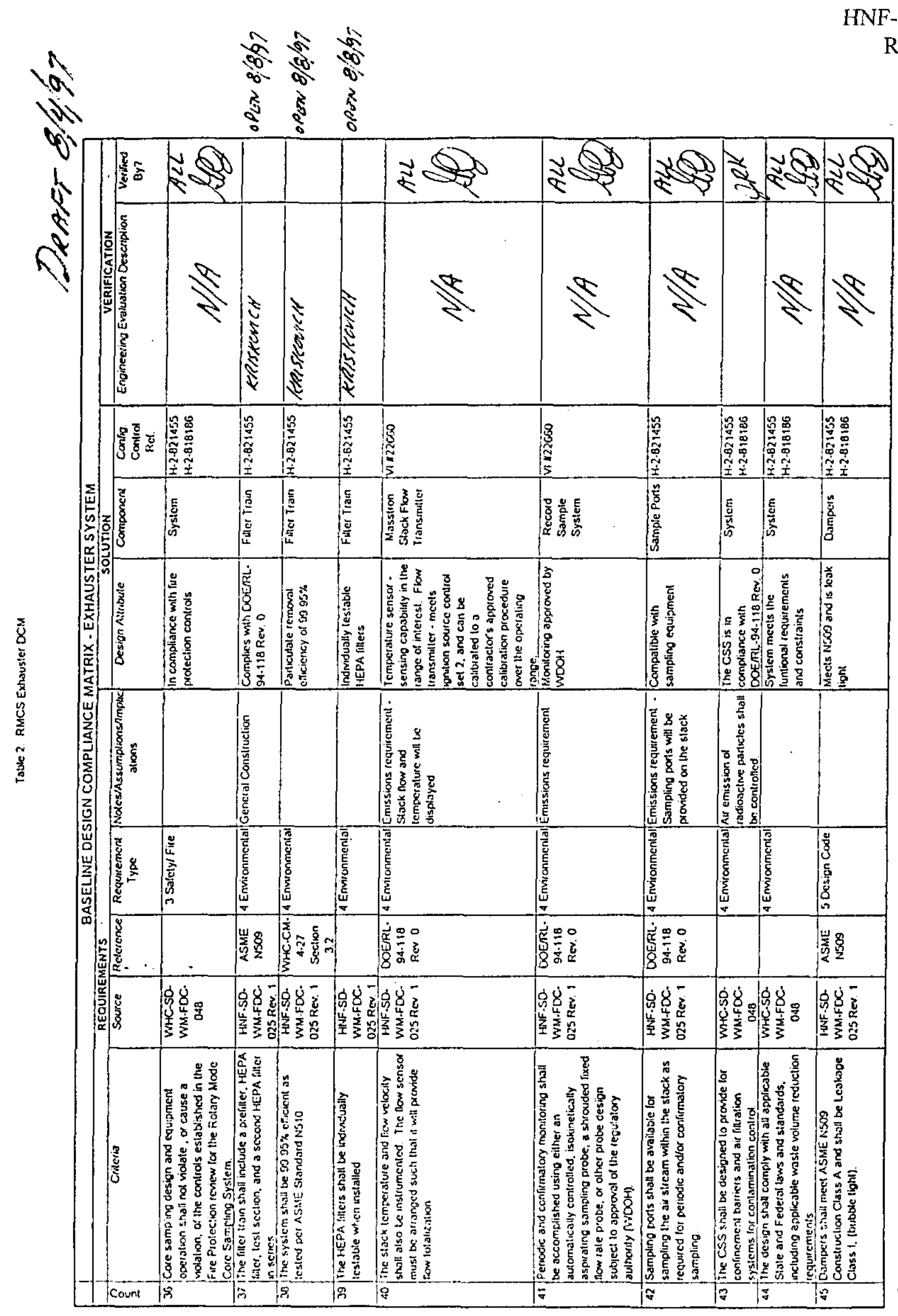

$\stackrel{n}{a}$

Page $5.1-10$ 
HNF-2369

Rev. 0

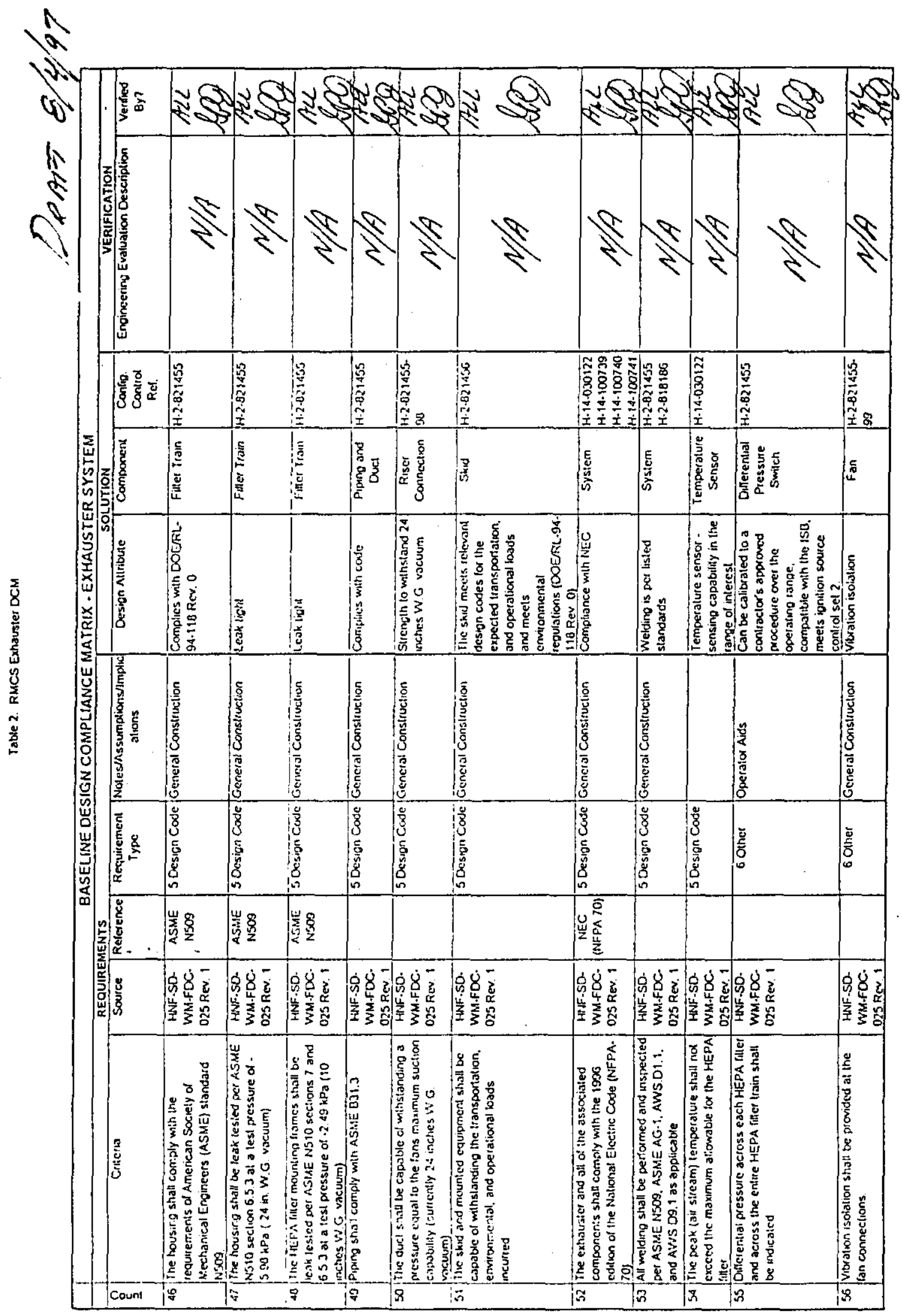

Page 5.1 - 11 


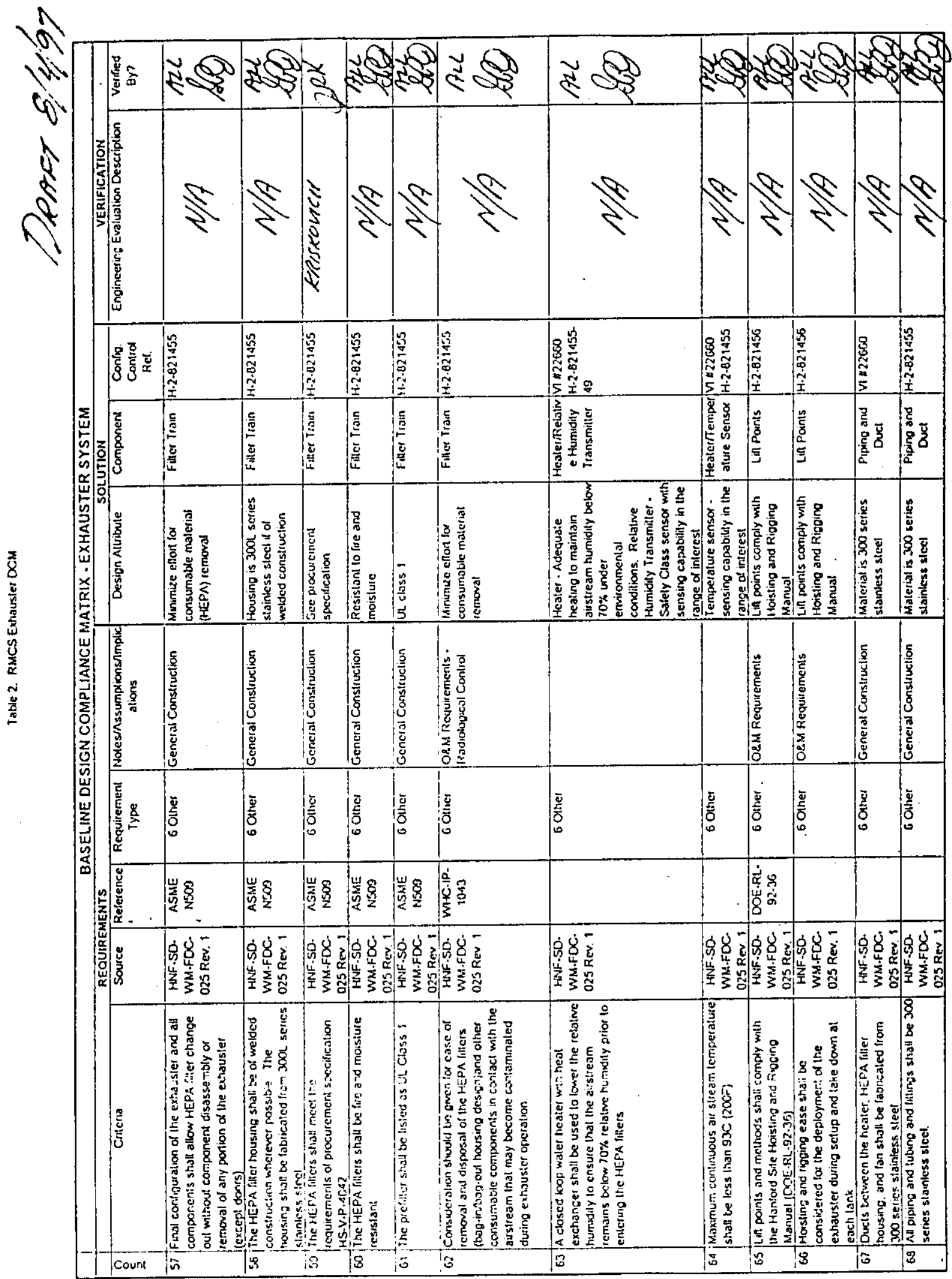




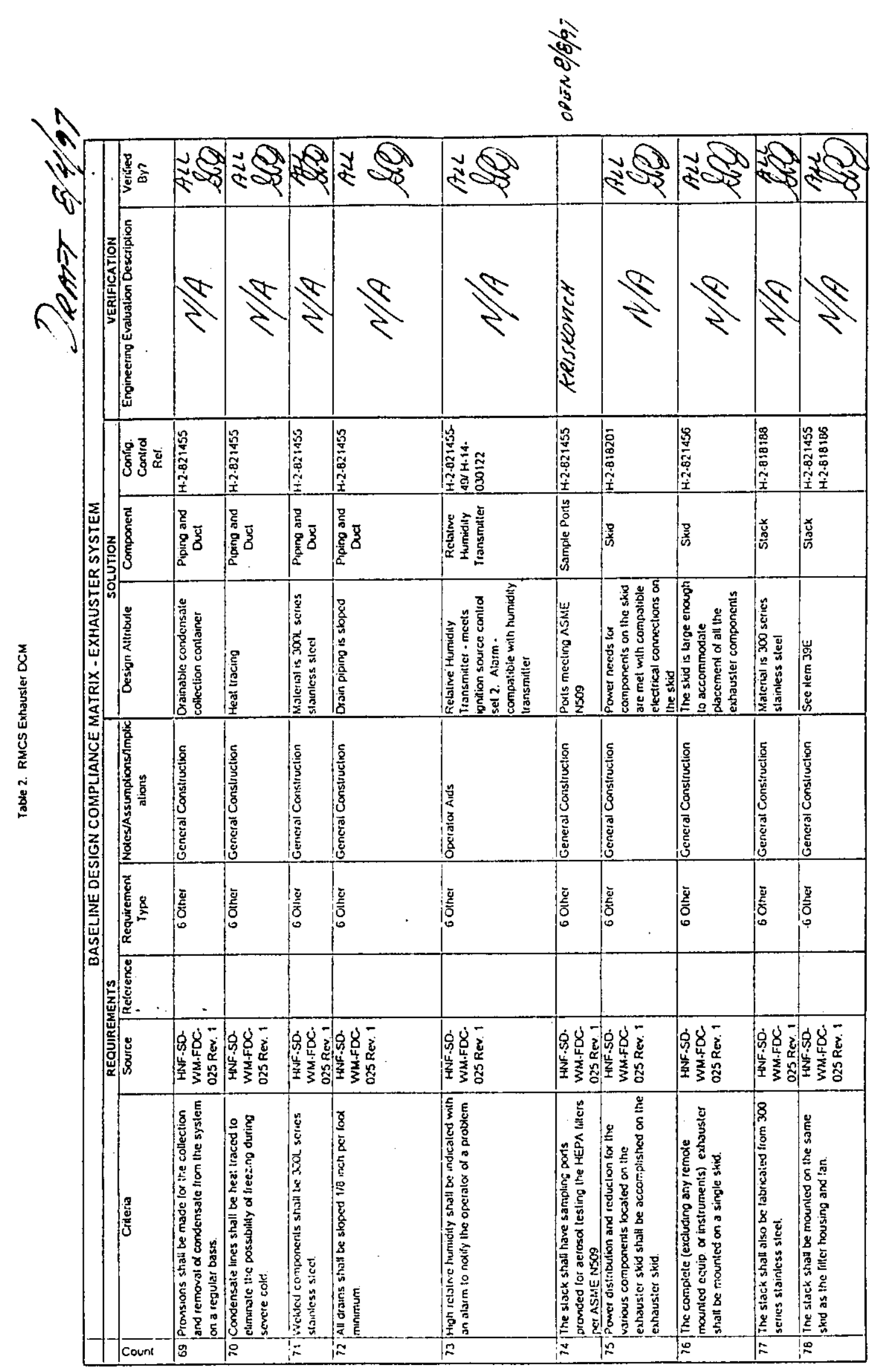

HNF-2369

Rev. 0 
HNF-2369

Rev. 0

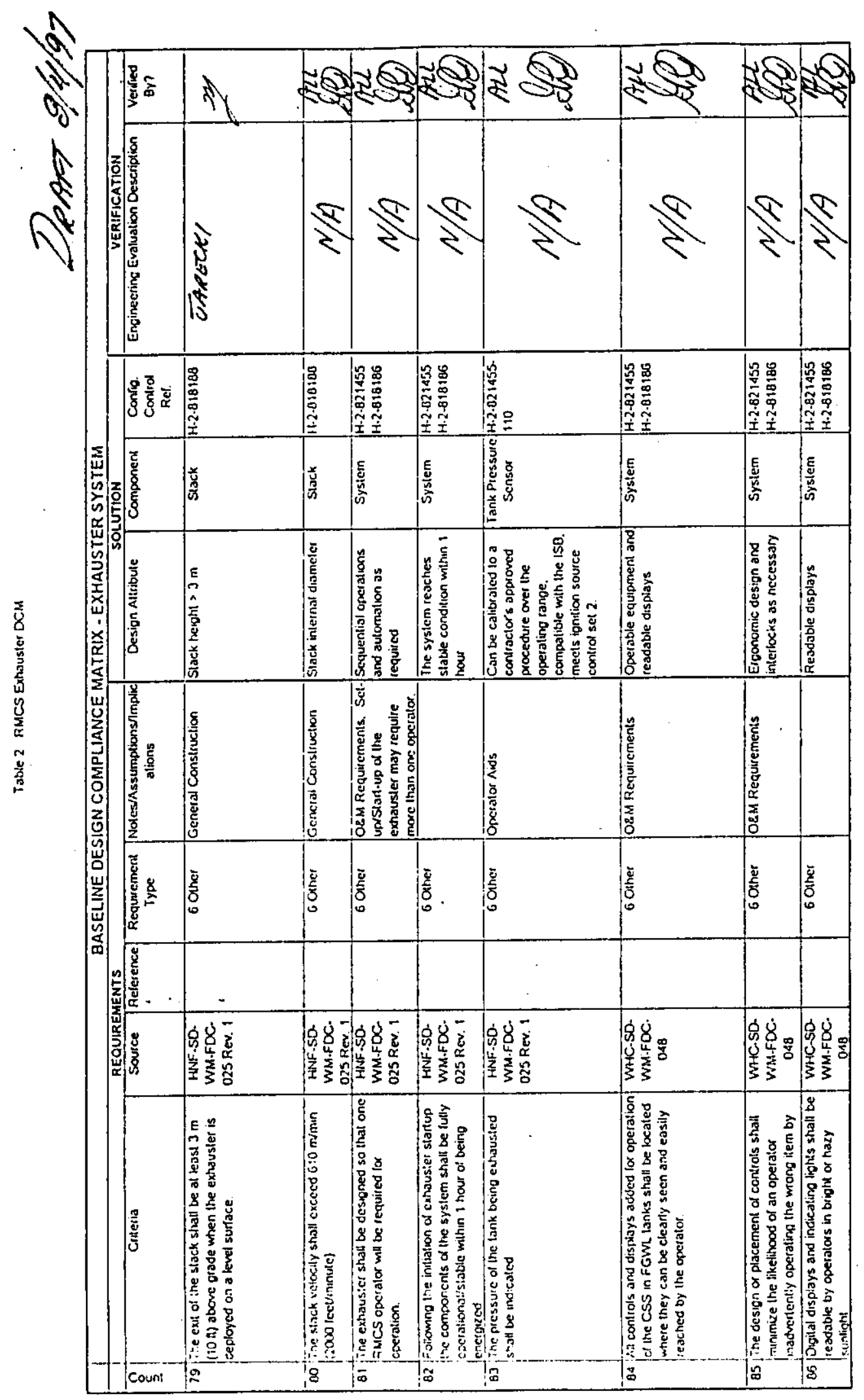

Page 5.1 - 14 
HNF-2369

Rev. 0

HINF-SD-WM-CR-062, Rev. 0

TABLE 3

ENVIRONMENTAL CONDITIONS

\begin{tabular}{|c|c|}
\hline \multirow[t]{8}{*}{ Climate and Natural Phenomenon } & $\begin{array}{l}\text { The weinher which is experienced on the Hanford } \\
\text { Site includes sun, snow, rain, blowing dust and } \\
\text { extreme temperatures. }\end{array}$ \\
\hline & $\begin{array}{l}\text { The maxinum wind speed is } 120 \text { knllhour ( } 80 \mathrm{MPH}) \\
\text { and may be acconpanied by snow, rain or blowing } \\
\text { dust. }\end{array}$ \\
\hline & $\begin{array}{l}\text { The exhauster shall be capable of operation under } \\
\text { the Hanford enviromental condition with } \\
\text { tentperature extremes of }-7 \text { to } 43^{\circ} \mathrm{C}\left(20 \text { to } 110^{\circ} \mathrm{F}\right) \text {. } \\
\text { sustained wind up to } 32 \mathrm{~km} / \mathrm{hr}(20 \mathrm{MPH}) \text {. }\end{array}$ \\
\hline & $\begin{array}{l}\text { The tenperatures range from }-23^{\circ} \mathrm{C} \text { to } 43^{\circ} \mathrm{C} \text {, (- } \\
\left.10^{\circ} \mathrm{F} \text { to } 110^{\circ} \mathrm{F}\right)\end{array}$ \\
\hline & The ground snow load is . $7 \mathrm{kPa}$ (15 psf). \\
\hline & $\begin{array}{l}\text { Consideration should be given for operation in } \\
\text { direct sunight, rain and snow loads. }\end{array}$ \\
\hline & $\begin{array}{l}\text { The exhususter shall not be danjaged if stored } \\
\text { outdoors within the temperatures of }-29 \text { and } 49^{\circ} \mathrm{C}(- \\
\left.20 \text { and } 120^{\circ} \mathrm{F}\right) \text {, during rain, snow load, direct } \\
\text { sunlight, and sustained high winds of up to } \\
112 \mathrm{hun} / \mathrm{br} \text { (SOMPH). }\end{array}$ \\
\hline & $\begin{array}{l}\text { The fitter housing shall be seismically qualified for } \\
\text { use at the DOE Hanford Washington State site, by } \\
\text { dynanic antlysis based on a free field horizontal } \\
\text { acc. of .12g. a free-fitld vertical acc. of } .08 \mathrm{~g} \text { and } \\
5 \% \text { critical damping. }\end{array}$ \\
\hline \multirow[t]{3}{*}{ Tanik Vapor: } & $\begin{array}{l}\text { The underground storage tanks are within the } \\
\text { temperature range of } 0 \text { and } 71^{\circ} \mathrm{C}\left(32 \text { and } 160^{\circ} \mathrm{F}\right) \\
\text { and the dirstrean at the top of the tank riser sliall be } \\
\text { assumed to be within the same range. }\end{array}$ \\
\hline & $\begin{array}{l}\text { The airstrean which will be exhausted from the } \\
\text { tank is expected to range hetween } 15 \% \text { and } 100 \% \\
\text { selative liumidity. }\end{array}$ \\
\hline & $\begin{array}{l}\text { The moisture within the air strean is expected to } \\
\text { lave a pH factor between } 12 \text { and } 14 \text {. }\end{array}$ \\
\hline
\end{tabular}

Page 16

Page 5.1 - 15 
5.2 DRAFT DESIGN COMPLIANCE MATRIX PUNCHLIST W/CLOSURE DOCUMENTATION

Page $5.2-1$ 


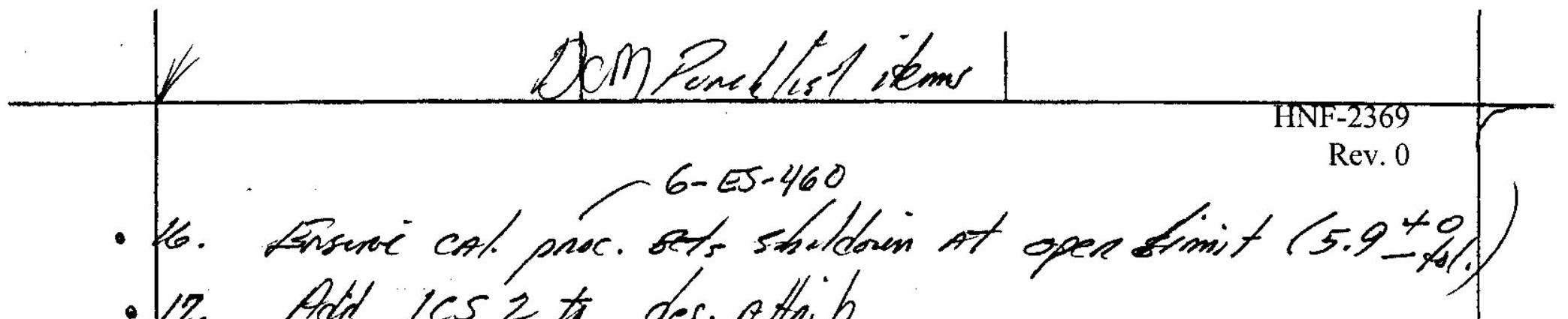

- ja. Aad leszt des. athib

18. Change des. atfrib to les 2

19. Thke out 1CS 2

Adid shildoun sttrubite

Chech if shutdoin occuns custhin 5 min peniod

20. Add 1052 b athil

$21 . " 4 "$

22. Remane iCSz to Atfib -6-ES-460

Add Shot dorm sunnt to nthub (Cheeh CAl. proc.)

24 Changet 1052 (moti)

Add solo in net evli

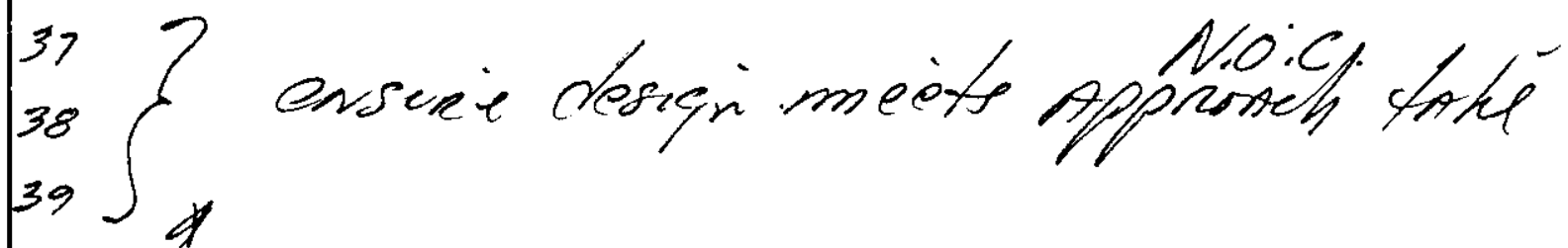

74.

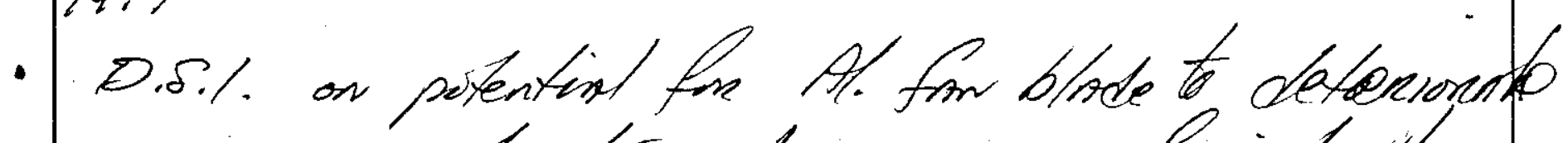
cue to condensic rizpons frim trivle.

$\underset{\substack{\text { ToNS } \\ 35500}}{\cos }$

Page 5.2 - 2 
HNF-2369

Rev. 0

\title{
COMMENTS ON THE EXHAUSTER DESIGN COMPLIANCE MATRIX
} CC Scaief III

\section{Environmental Limits:}

\author{
Operating Temperature: $\quad 10^{\circ} \mathrm{F}$ to $110^{\circ} \mathrm{F}$ \\ Maximum Ambient (storage): $\quad-20^{\circ} \mathrm{F}$ to $120^{\circ} \mathrm{F}$ \\ Relative Humidity: \\ $15 \%$ to $100 \%$ \\ $\mathrm{pH}$ of exhaust stream moisture: 12 to 14
}

Item 16

Shutdown exhauster on excessive HEPA DP (5.9 inWG)

This requirement is achieved with a Dwyer Model 1950-10 differential pressure switch. The contacts (NC) from the pressure switch are wired into the Variable Frequency Drive (VFD) for the fan motor and provide a shutdown interlock. The pressure switch contacts open upon detection of excessive DP.

The pressure switch is rated for operation from $-40^{\circ} \mathrm{F}$ to $140^{\circ} \mathrm{F}$. The switch is connected across the filter using static pressure lines that are exposed to the ambient environment. Per FDC-025, the tank vapor stream maximum temperature is $160^{\circ} \mathrm{F}$. If the tank vapor were at $160^{\circ} \mathrm{F}$, it is inconceivable that the static pressure lines could transmit enough heat to place the switch out of its recommended operating temperature range. No relative humidity range was specified, however, the enclosure is rated as weatherproof.

The VFD is specified to operate from $0^{\circ} \mathrm{C}$ to $50^{\circ} \mathrm{C}\left(32^{\circ} \mathrm{F}\right.$ to $\left.122^{\circ} \mathrm{F}\right)$. The storage temperature range is $-40^{\circ} \mathrm{C}$ to $85^{\circ} \mathrm{C}\left(-40^{\circ} \mathrm{F}\right.$ to $\left.185^{\circ} \mathrm{F}\right)$. An RCR comment (\#5) was submitted by $\mathrm{J}$. Dormant regarding the temperature range. The manufacturer's response to questions (per JD Criddle Jr) regarding performance at lower temperatures was that it will probably operate at the lower temperature and if it won't, it simply will not run. It is doubtful that the lower temperature would affect the shutdown function (my comment). The VFD is in a weatherproof enclosure.

Item 17

Any exhauster electrical components exposed to the air stream meet Standing order 97-01.

The equipment in the gas sample monitoring cabinet has been reviewed by the FGEAB, Report number FGEAB-97-029. Other equipment such as the pressure switches, temperature sensor, and the humidity sensor are approved for use in a Class I, Division 2 location as a minimum. The pressure switches use an Intrinsic Safety Barrier (Crouse-Hinds GHG12230) to achieve compliance. These barriers are located within the sample monitoring cabinet that is environmentally controlled. As such, they will meet the temperature and humidity requirements. No attempt has been made to assess the effect of temperature and humidity on the ability of the other components to meet the ignition requirements of Standing order 97-01. These devices were approved by the $F G E A B$ based on their non-sparking operation under normal conditions. This is not expected to be altered by the temperature and humidity ranges they will encounter. 
HNF-2369

Rev. 0

\section{Item 19}

Shutdown exhauster on $h \mathrm{i}$ and low flow.

This is accomplished using the Masstron flow monitor and a Yokogawa controller. The controller provides outputs to Relays $K 5$ and $K 6$ which are used to shut down the VFD. These relay contacts are in the same shutdown circuit as the DP switch (Item 16). These components are all located in the air sampling cabinet which is environmentally controlled.

Item 22

Shutdown exhauster when vacuum exceeds 3 inWG.

This is accomplished with a Dwyer pressure switch, Model 1950-05 and operates in an identical fashion to the DP switch with an interlock to the VFD. The discussion above (Item 16 ) regarding all the components is identical.

pH Requirement The $\mathrm{pH}$ of the moisture within the air stream is not expected to have any immediate effect on any of the instrumentation exposed to the air stream. The caustic nature of any condensed moisture might have a long term effect on some components, however, any degradation is expected to be determined through normal calibration and operational checks. 
HNF-2369

Rev. 0

DON'T SAY IT -..- Write It!

TO: G. P. Janicek

$\$ /-12$

cc:
R. M. Boger
K. V. Scott
File/LB CEH
$57-12$
$57-12$

DATE: December 12. 1997

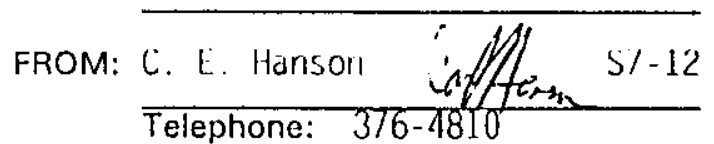

SUBJECT: REVIEW COMMENT RECORDS ON THE DESIGN COMPLIANCE MATRIX FOR THE RMCS, HNF-SO-WM-CR-062, REV. O

The completed review comment records for the subject report are attached. All comments were resolved, and the reviewers approved the report.

If you have any questions. please contact me at the number above or Keith Scott at 376-5445.

meg

Attachment 
HNF-2369

Rev. 0

Attachment to DSI

REVIEW COMMENT RECORDS ON

THE DESIGN COMPLIANCE MATRIX FOR

THE RMCS. HNF-SO-WM-CR-062. REV. 0

Consisting of 12 Pages

(including cover page)

Page 5.2 - 6 
HNF-2369

Rev. 0

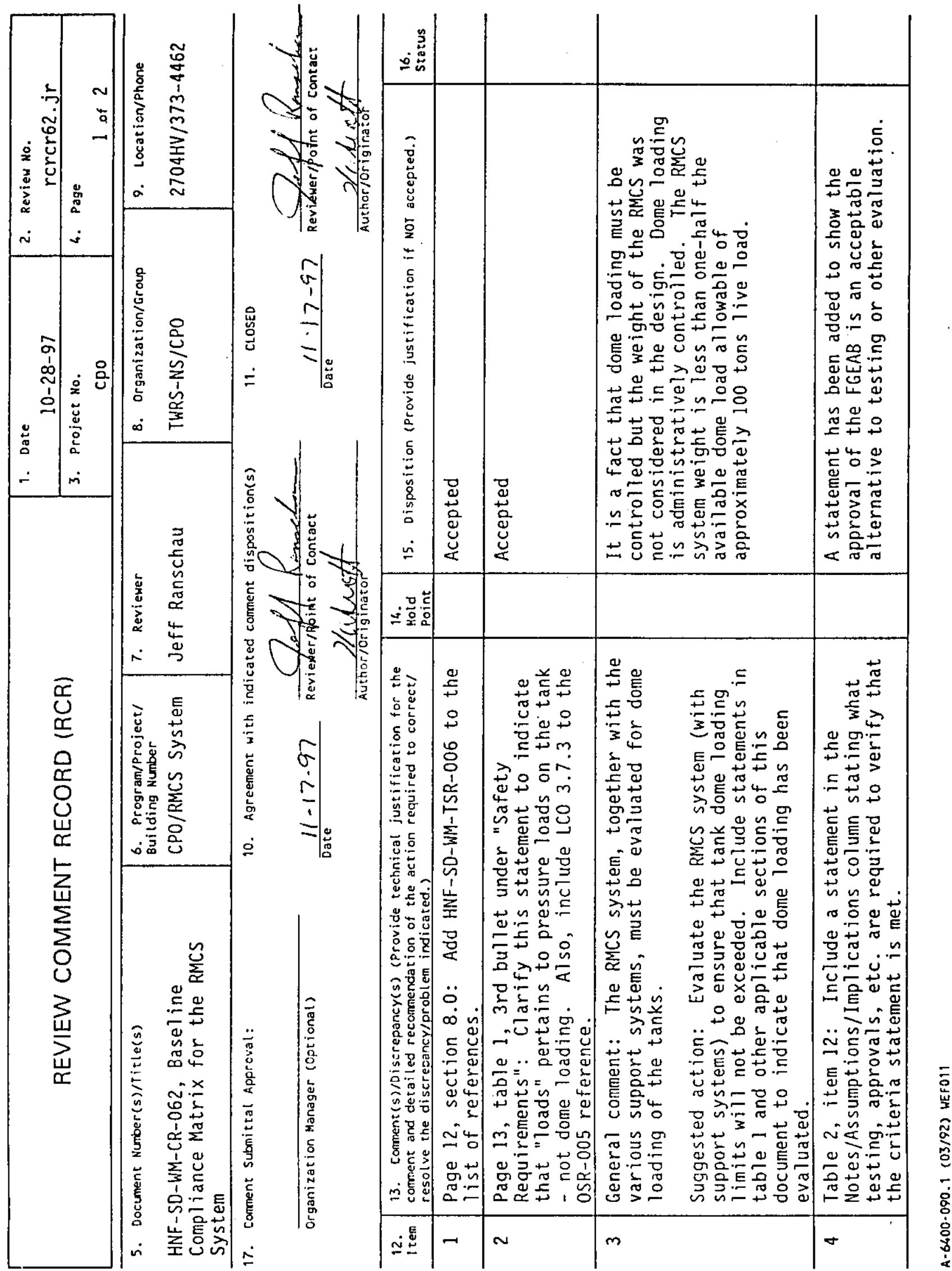

Page 5.2 - 7 
HNF-2369

Rev. 0

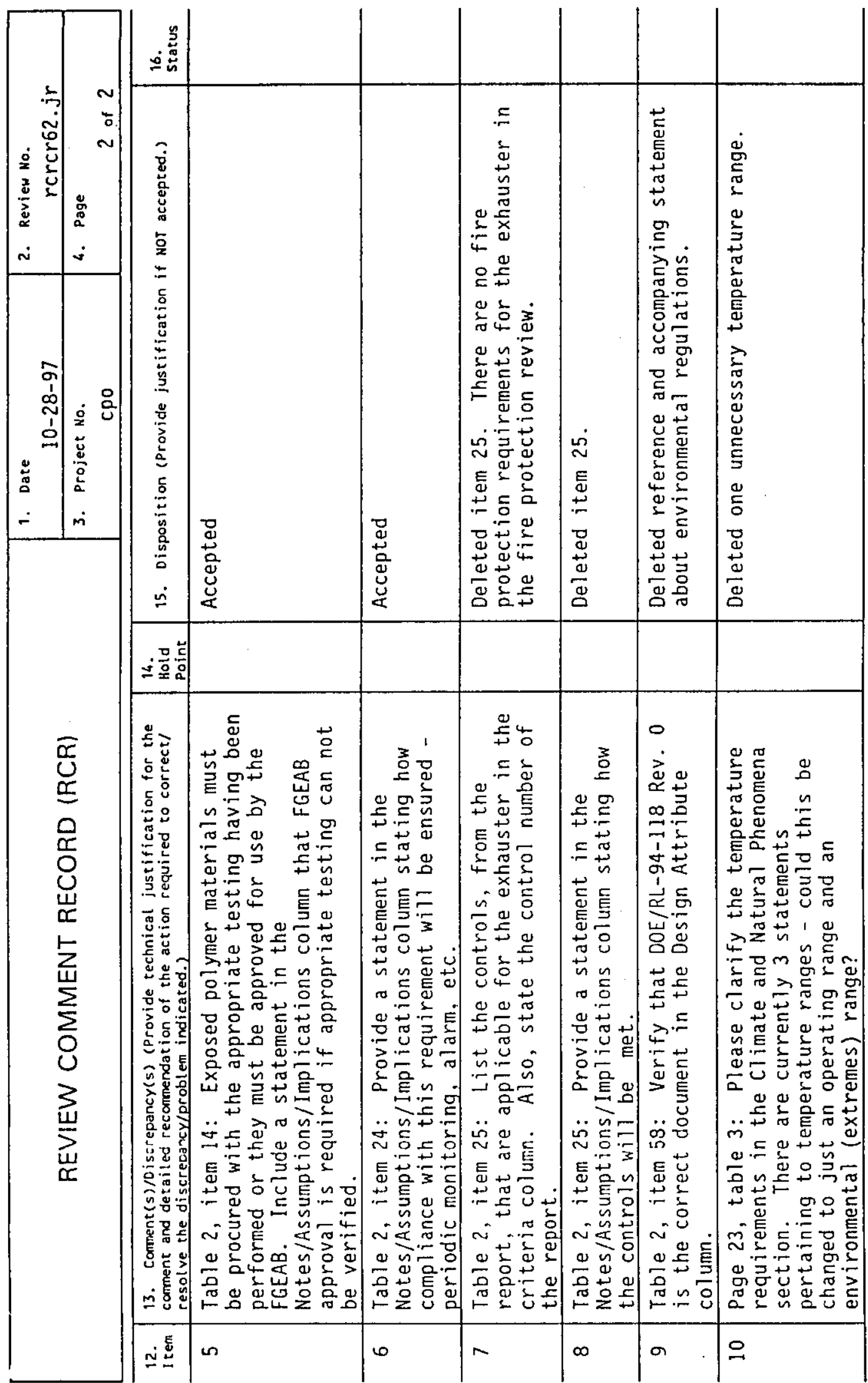

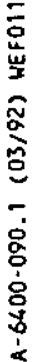

Page 5.2 - 8 
HNF-2369

Rev. 0

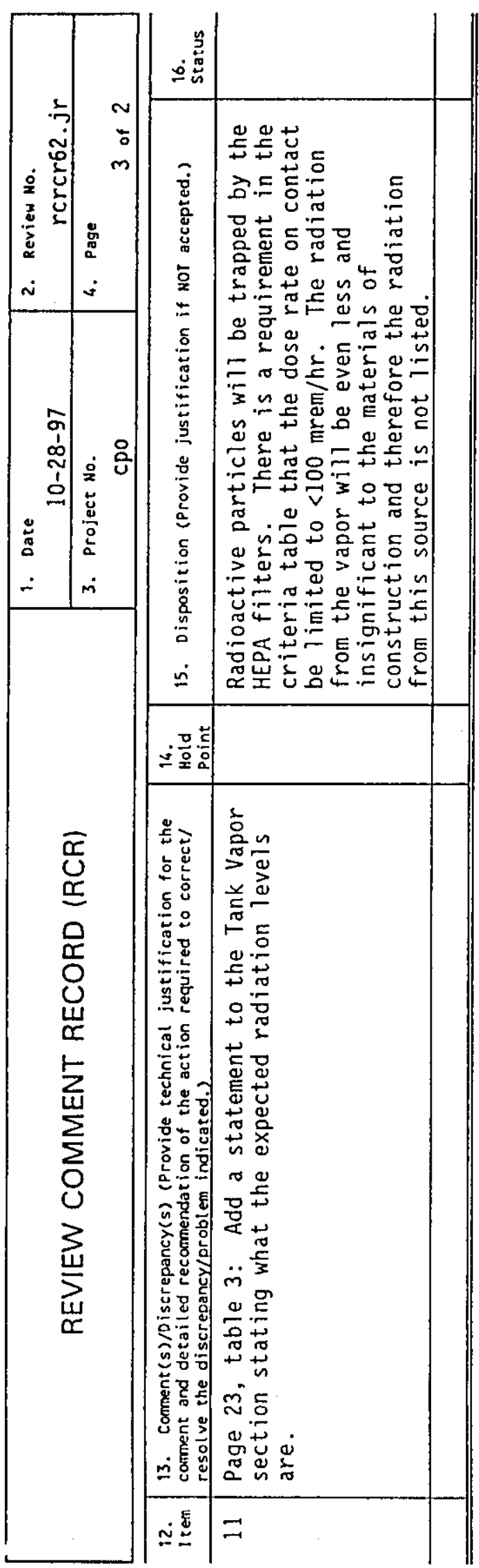

Page 5.2 - 9 


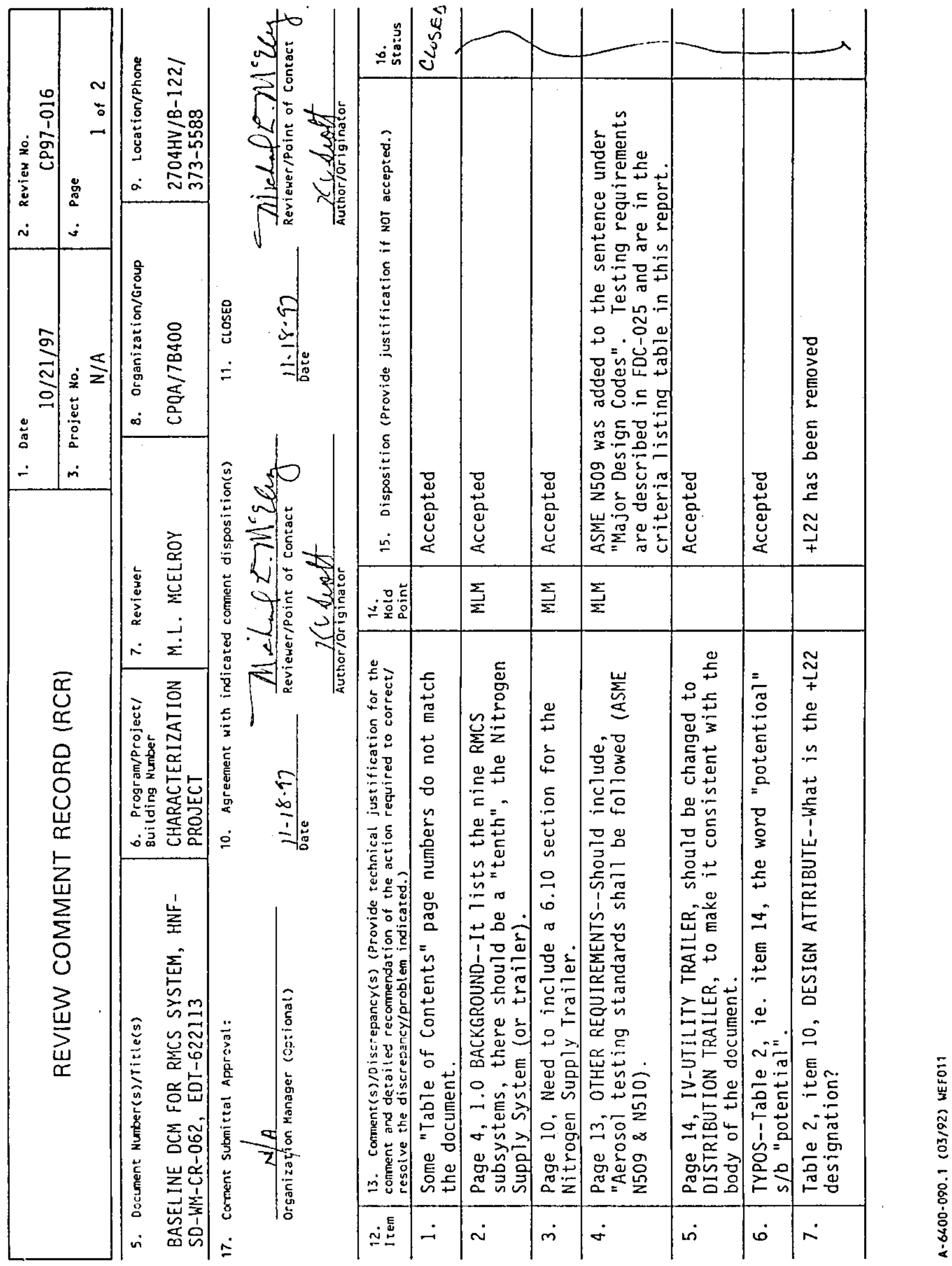

Page $5.2-10$ 
HNF-2369

Rev. 0

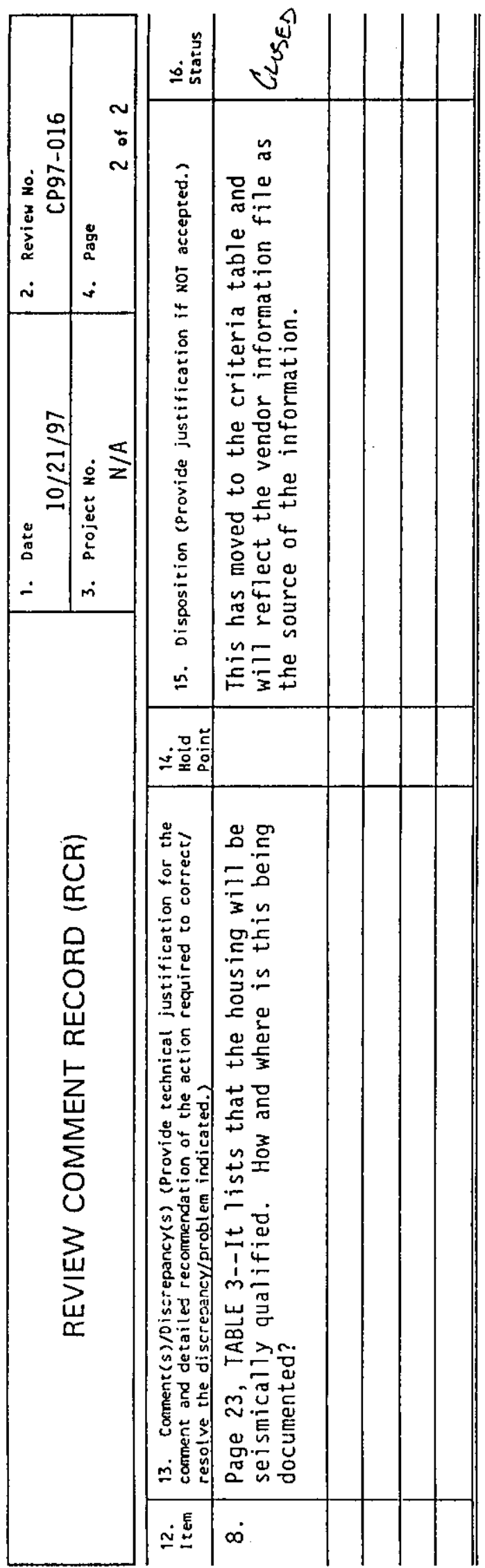


HNF-2369

Rev. 0

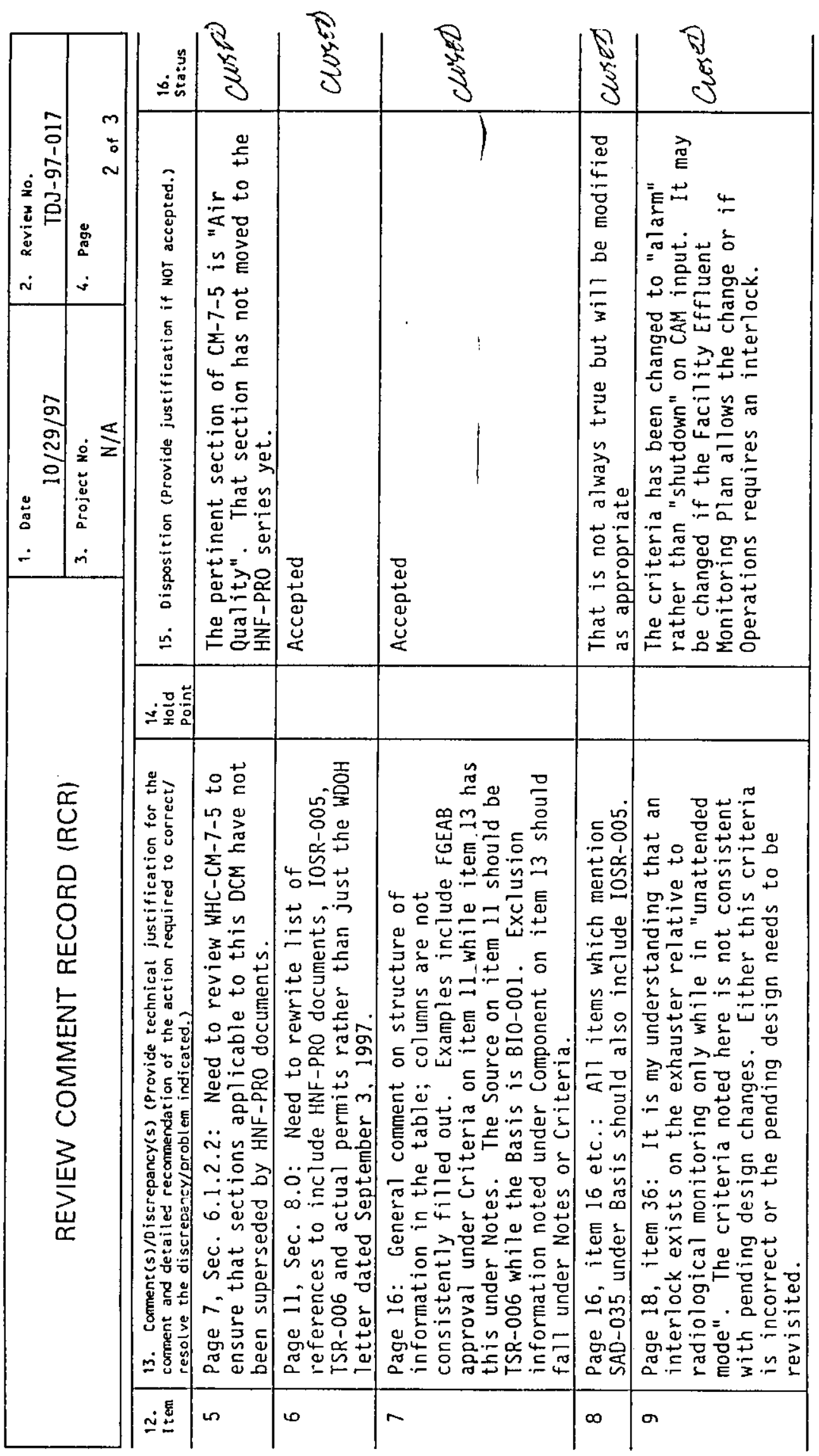

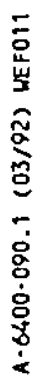

Page $5.2-13$ 


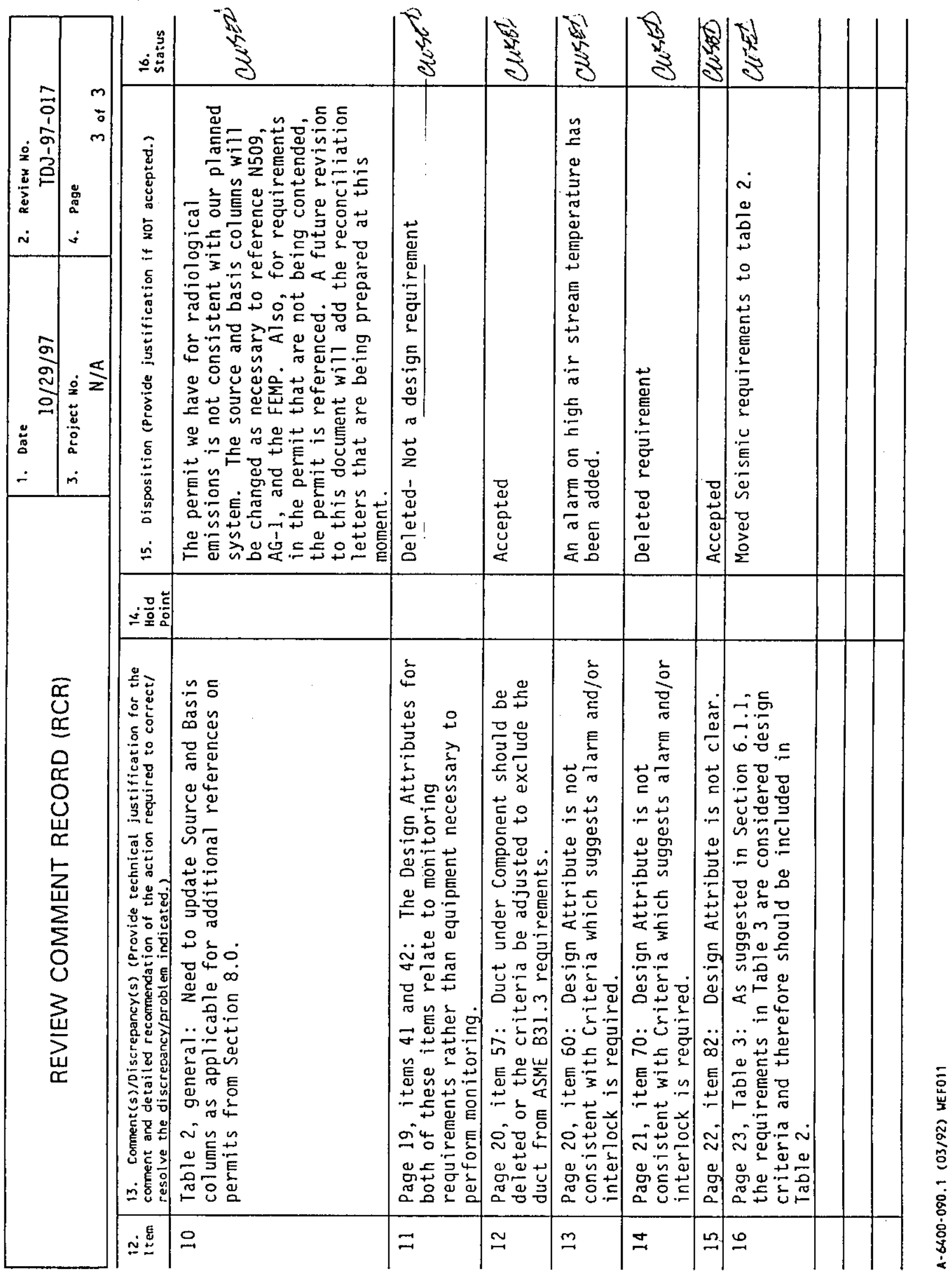




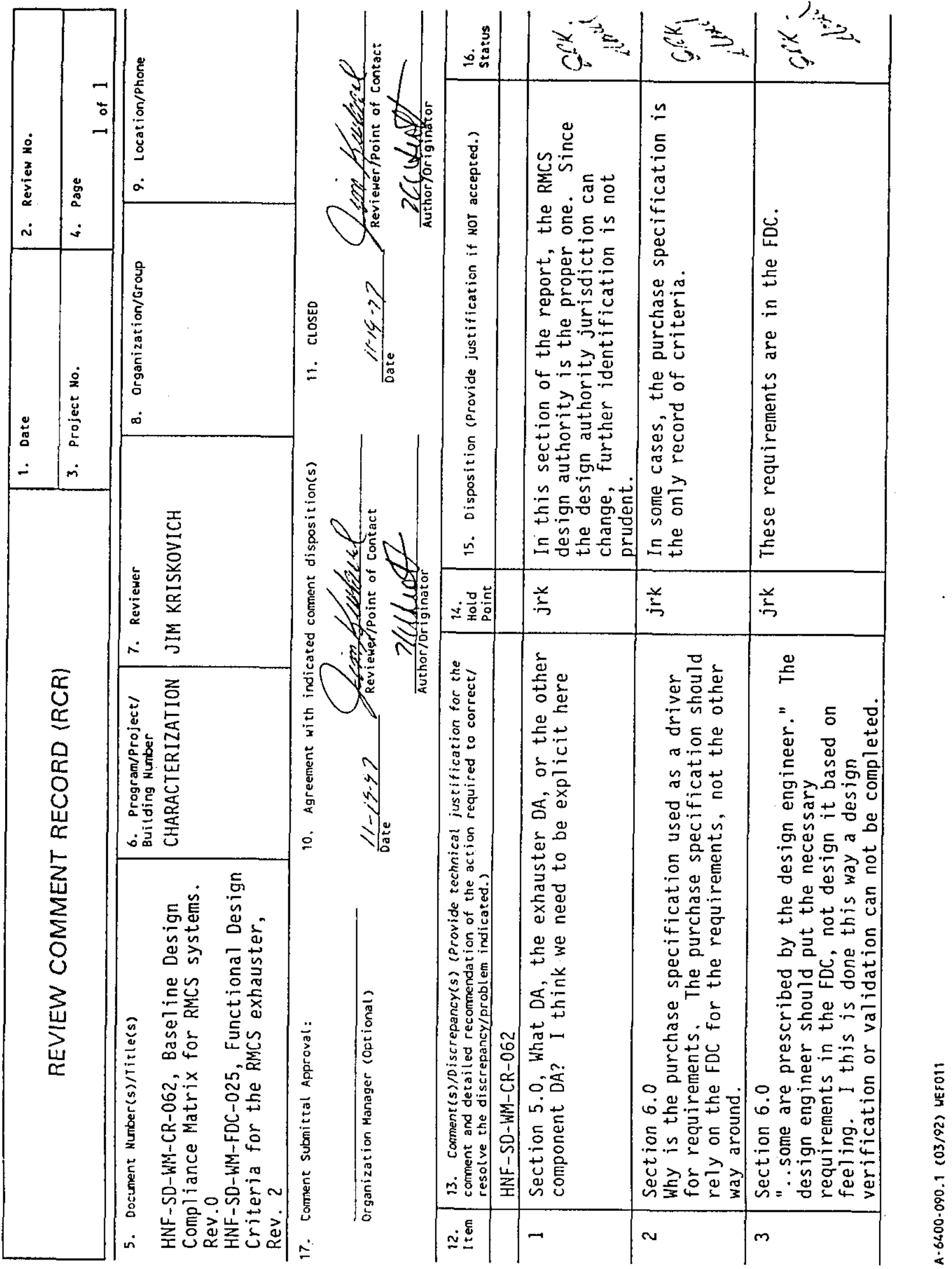

Page $5.2-15$ 


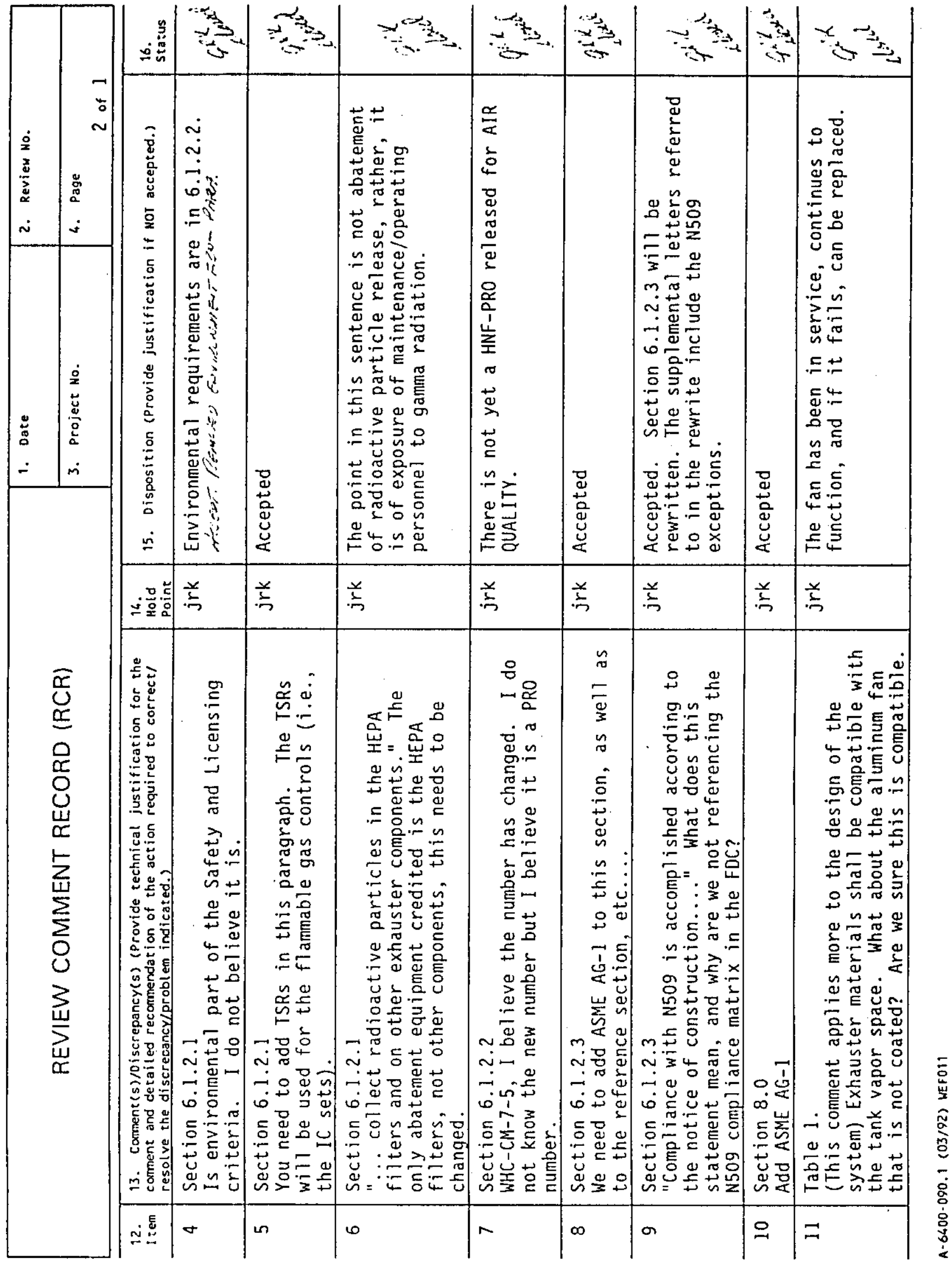




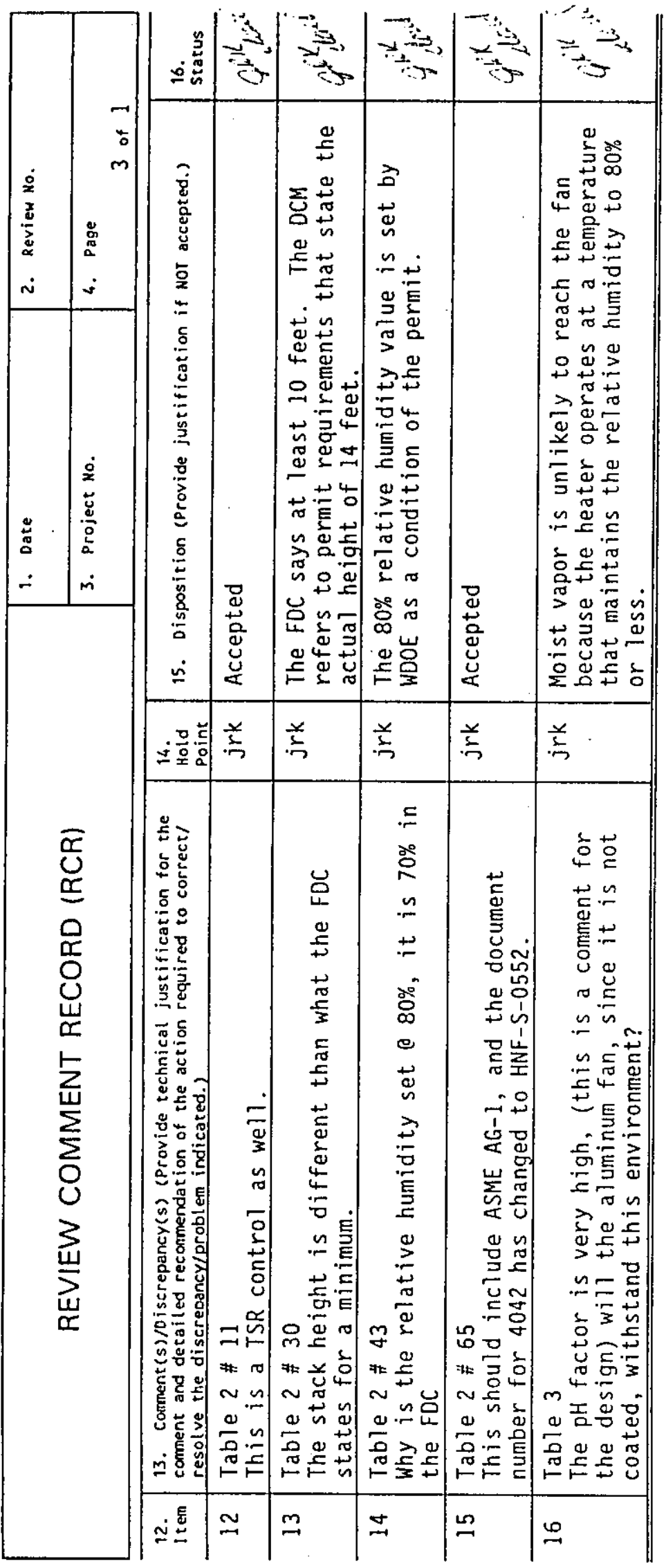


HNF-2369

Rev. 0

\subsection{DESIGN REVIEW COMMITTEE MEMBERSHIP/CHARTER}

Page $5.3-1$ 
HNF-2369

Rev. 0

Subject: CHARACTERIZATION PROJECT - DESIGNATION OF DESIGN REVIEW CONMITTEE FOR DESIGN VERIFICATION OF CHARACTERIZATION EQUIPMENT SAFETY CLASS DESICN BASELIINE DOCUMENTATION

Reference: IHF-CM-6-1, Standard Enginecring Practices, Section EP-4.1, Design Verification Requirements.

The purpose of this memo is to re-establish a Characterization Project Design Review Committee (DRC) for conducting Formal Design Reviews in accordance with reference 1. The scope of DRC activities will address changes to Characterization Equipment Engineering design baseline(s). Particularly, elements classified as Safety Class Systems, Structures, and Components (SSCS). It is intended that this ORC remain together as a Team to address ongoing and future changes to the design baseline as might be required. This action is taken to compensate for the loss of qualified individuals (due to retirements, organizational changes,...etc.) from the previous DRC tasked for this purpose.

The Design Review Committee members and their primary areas of responsibility are listed below. The chairman was selected by the Project Manager, Characterization Equipment Engineering Projects, R. E. Raymond. The conunittee members were selected by the chairman with input from the Manager, Remote Sensing and Sampling Equipment Enginecring, C. E. Hanson. Additional, ad hoc, members with specific expertise will be asked to participate in certain reviews as the need for their expertise arises.

\section{DESIGN REVIEW COMMITTEE}

G. P. Janicek

J. E. Corbett

T. D. Jarecki

N. J. Milliken

C. C. Scaief

L. F. Hill (alternate)

M. L. McEIroy

D. C. Board (a]ternate)

J. A. Ranschau

J. A. Harvey (alternate)
Design Review Chairman (Design Authority)

Design Review Secretary (Mechanical Eng.)

Characterization Operations (Mech. Des. Eng.)

Safety Analysis Engineering

TWRS Equipment Engineering (Elec./I\&C Eng.)

G. P. Janicek, Design Authority

Design Review Chairman

Characterization Project Design Authority

Concurrence: R. E. Raymond, Project Manager Characterization Equipment Engineering Projects

Page $5.3-2$ 
HNF-2369

Rev. 0

Janicek, George P

From:

Gcorge P Janicck

Sent:

Monday, January 20, 1997 4:16 PM

To:

Donald C Board: John E Corbelt; Jerry A Harvey; Lowell F Hill; George P Janicek; Theodore

Cc: D Jarecki; Michael L McElroy; Nancy J Milliken; J A (Jeff) Ranschau: C C IIl (Chuck) Scaicf

Subject: Carl E Hanson; Richard E Raymond; James A Robinson; Eric J Waldo

DRC Design Revicw Briefing - RMCS Exhausler System

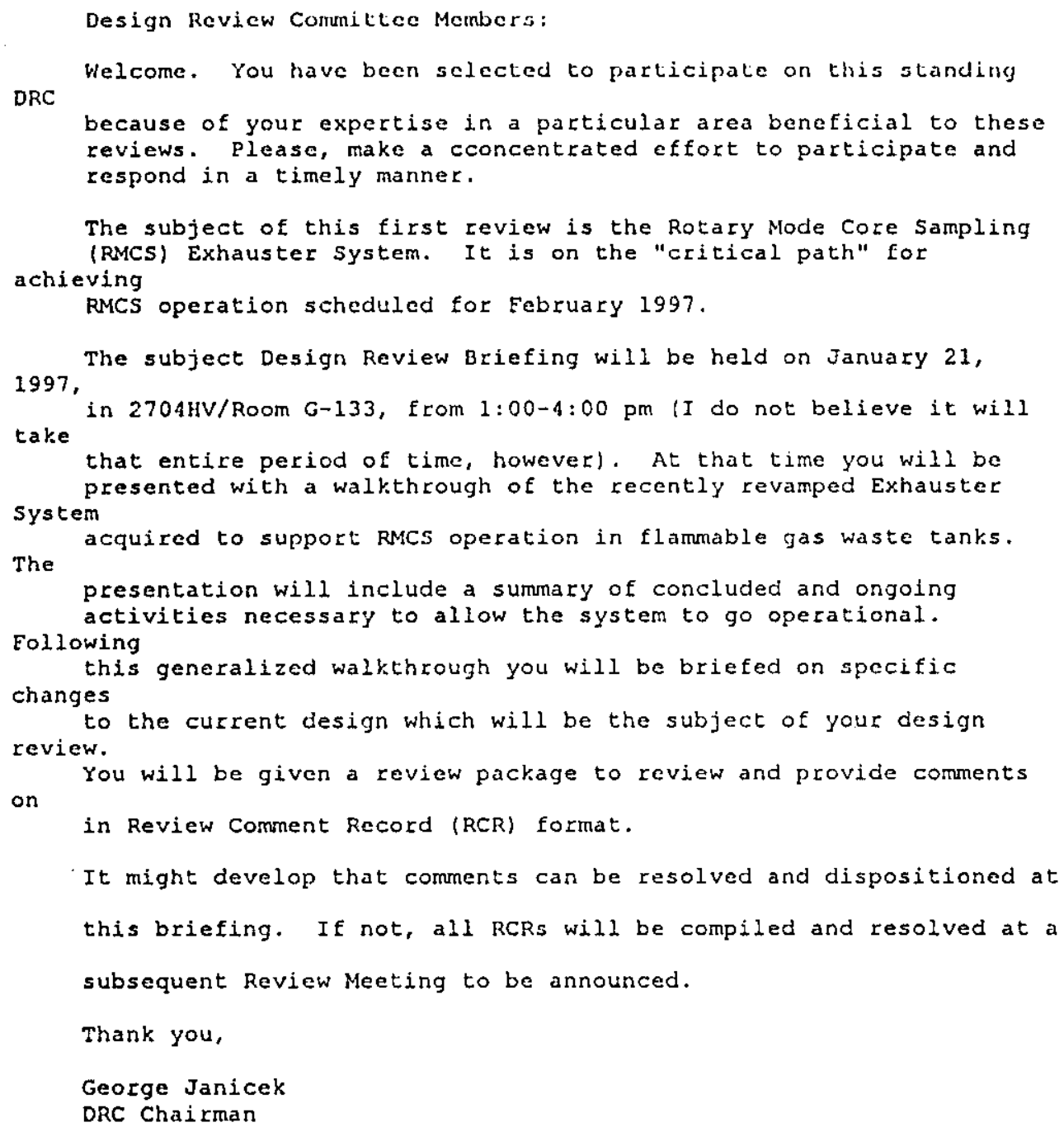


HNF-2369

Rev. 0

The purpose of this memo is to document a revision to the Design Review Committee (DRC) previously established by Reference 1. Reference 1. allowed for this as the need arose for additional expertisc in performing the design verification process. Reference 2. expanded the charter of the DRC from one of only reviewing "changes to the Exhauster Interlock System" to also reviewing the "entire design of both the Exhauster and Exhauster Interlock System" while specifically focusing only on safety structures, systems, and components (safety SSCS).

The DRC is herewith revised as follows:

J. E. Corbett will leave the DRC as regards activities associated with the DRC's expanded scope. He will be replaced as Design Review Secretary and reviewer member of the DRC by G. T. Frater.

J. R. Kriskovich, currently Ventilation Systems Design Authority and member of the Flammable Gas Board, is added to the DRC as a reviewer member.

J. M. Dormant, a member of the Team that recently performed a critical review of Characterization Equipment Engineering's design process (along with DRC members Frater and Scaief), is added to the DRC in an advisory capacity.

The composition of the DESIGN REVIEW COMMITTEE is thus: 
HNF-2369

Rev. 0

Subject: DRC INDIVIDUAL RESPONSIBILITIES FOR PERFORMING OESIGN VERIFICATION OF EXHAUSTER \& EXHIAUSTER INTERLOCK SYSTEM SAFETY SSC DESIGN.

\section{DESIGN REVIEW COMMITTEE}

G. P. Janicek

G. T. Frater

T. D. Jarecki

N. J. Milliken

C. C. Scaief

L. F. Hill (alternate)

M. L. McElroy

D. C. Board (alternate)

J. A. Ranschau

J. R. Kriskovich

J. M. Dormanl
Design Review Chairman (Characterization Design Authority) - Overall review, adherence to all requirements, proper documentation, maintenance of configuration control, design authority purview.

Design Review Secretary (Electrical Eng.) adherence to design verification process, review of electrical power/distribution portions of design.

Characterization Operations (Mech. Des. Eng.) review of design from operability and maintainability perspectives, human factors, normal and abnormal conditions, worker safety.

Safety Analysis Engineering - review of design for adherence to $S A$ requirements, maintenance of safety functionality and reliability of that functionality, ensuring no degradation of safety functionality relied on for safe operation.

TWRS Equipment Engineering (I\&C Design Authority) - review of I\&C portions of the design, including both hardware and software, flamiable gas requirements pertinent to same.

Quality Assurance - overall review of design as pertinent to all areas of QA purview.

Safety - overall review of design as pertinent to all areas of Safety purview, including, radiological, toxicological potential releases and immediate worker exposure to same.

TWRS Equipment Engineering (Ventilation Systems Design Authority) - overall review of exhauster system for adherence to ventilation requirements, flammable gas requirements, primarily mechanical and process portions.

Characlerizalion Projecl - overall review of design for proper interfacing with other portions of sampling system. 
HNF-2369

Rev. 0

Janicok, Goorgo P

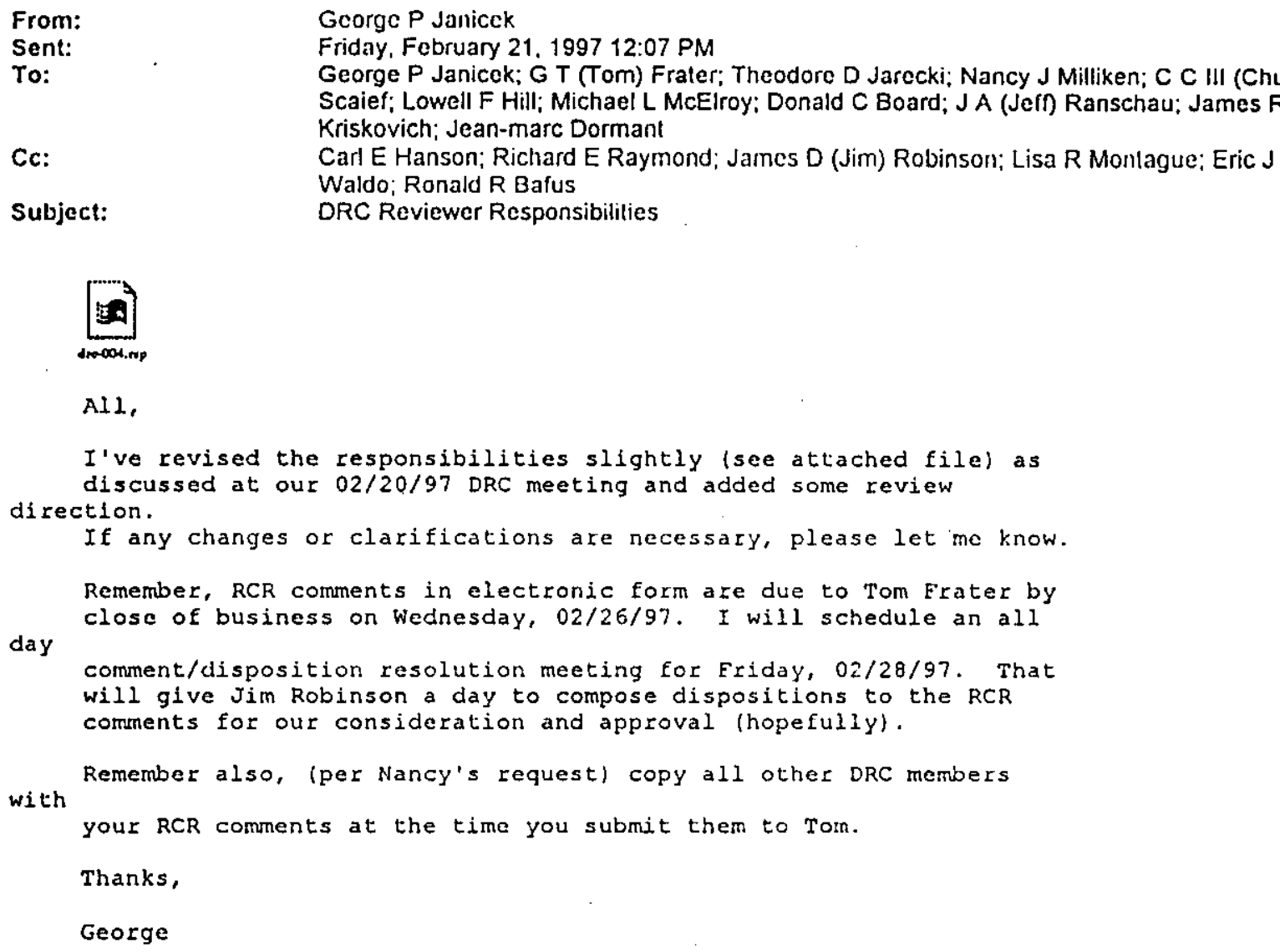


HNF-2369

Rev. 0

-File: DRC-004.RSP

Subject: DRC INOIVIDUAL RESPONSIBILITIES FOR PERFORMING DESIGN VERIFICATION OF EXHAUSTER \& EXHAUSTER INTERLOCK SYSTEM SAFETY SSC DESIGN.

\section{DESIGN REVIEW CONMITTEE}

G. P. Janicek

Design Review Chaiman (Characterization Design Authority) - Overall review. adherence to. all requirements. proper documentation. maintenance of configuration control, design authority purview. mechanical design (prime).

G. T. Frater

Design Review Secretary (Electrical Eng.) - adherence to design verification process. review of electrical power/distribution portions of design. including grounding/bonding.

T. D. Jarecki

Characterization Operations (Mech. Des. Eng.) review of design from operability and

maintainability perspectives, human factors, normal and abnormal conditions. worker safety, mechanical design.

N. J. Milliken

Safety Analysis Engineering - review of design for adherence to SA requirements, maintenance of safety functionality and reliability of that functionality. ensuring no degradation of safety functionality relied on for safe operation.

C. C. Scaief

L. F. Hill (alternate)

M. L. MCElroy

J. A. Ranschau
WWS Equipment Engineering (I\&C Design

Authority) - reviow of I\&C portions of the design. including both hardware and software. flammable gas requirements pertinent to same.

Quality Assurance - overall review of design as D.

C. Board (alternate) pertinent to all areas of QA purview per WHC-CM-4-2. Quality Assurance Manual.

Safety - overall review of design as pertinent to all areas of Safety purview. including. radiological. toxicological potential releases and immediate worker exposure to same. 
J. R. Kriskovich

J. Dormant
TWRS Equipment Engineering (Ventilation Systems Design Authority) - overall revicw of exhauster system for adherence to ventilation requirements. flamable gas requirements. primarily mechanical and process portions.

TWRS Projects - advisor to design process, review of environmental qualification of design and equipment specification.

\section{DESIGN REVIEW DIRECTION}

Review of the design shall be conducted as if the design media we've been given represented a brand new design receiving final design verification. That is. all we have before us are design requirements and the design media purported to satisfy those requirements. We have no other knowledge or infomation. Nothing has been specified. procured, fabricated. or tested. as far as we know. The only exception to this is the software for the interlock System PLC. Design verification for the software shall consist of review of the test plan. test procedure. and test results of the Qualification Testing performed in this regard. We will not review the software logic documentation as was done for the ECN changes recently reviewed by the DRC.

Each individual shall include interfaces with other SSCS as part of their review and area of responsibility (e.g. electrical. mechenical. I\&C....etc.). as required.

Remember. the review is to concentrate only on safety SSCS. This not only includes all things inherent to a particular safety SSC required for it to reliably perform its safety function. but also. all other SSCs (and/or conditions. e.g., environmental) which could impact a particular safety SSC and/or its safety function.

If any reviewer picks up a deserving comment. which is not their imediate responsibility. pass it along electronically to the responsible individual (as a minimum) and make a note to ensure that it is captured at our conment resolution meet ing( $s$ ). 
HNF-2369

Rev. 0

G. P. Janicek, Chairman, Design Review Committee Characterization Equipment Engineering Lockheed Mart in Hanford Corporation P.0. Box 1500 MSIN S7-12

Richland, Washington 99352

Dear Mr. Janicek:

CHARACTERIZATION ENGINEERING DESIGN REVIEW OF THE EXHAUSTER INTERLOCK SYSTEM

References: 1) Internal lilemo, G. P. Janicek, L MHC, to Distribution, "Characterization Project - Designation of Design Review Committee for Design Verification of Characterization Equipment Safety Class Design Baseline Documentation," 74740-97-002, dated January 20, 1997.

2) WHC-SD-WH-FDC-045, Rev. 0, "Functional Design Criteria for Flammable Gas Detection and Shutdown System."

3) WHC-SO-WM-SAD-035, Rev. 0-a, "A Safety Assessment for Rotary Mode Core Sampling in Flammable Gas Single Shell Tanks, Hanford Site, Richland, Washington."

I am requesting that the Design Review Committee (DRC), (Reference 1), expand its charter by conducting a second formal design verification process on the entire existing design of the Exhauster Interlock System.

Recent activities have revealed that environmental factors were not adequately evaluated in the specification and deployment of some components of this system. This demonstrates that performance requirements for this system, as specified in Reference 2, or as relied on in the Safety Assessment, (Reference 3), are not being universally met. It is imperative that all safety design related problems be identified, and that all requirements of the system are fully met before field deployment of the equipment.

Please expand the DRC charter to include review of the Exhauster Interlock System, with particular emphasis on Safety Class systems, structures, and components and their performance requirements. If necessary, supplement the membership of the ORC for accomplishing this task. 
HNF-2369

Rev. 0

G. P. Janicek

NHC -9750857

(7) Page 2

January 31, 1997

This task must be completed as soon as possible, consistent with full rigor,

to support completion of all engineering work before February 12, 1997. If

you require my assistance in any manner, please see me personaliy or you may contact me on 373-3647.

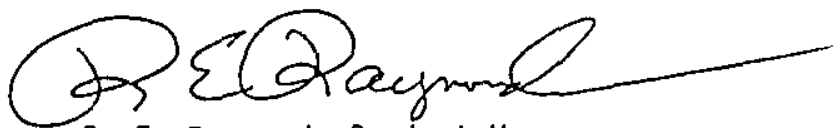

R. E. Raymond, Project Manager

Characterization Equipment Engineering Projects

Tank Waste Remediation Systems

Irm 
HNF-2369

Rev. 0

\subsection{REVIEW COMMENT RECORD (RCR) FORMS}

Page 5.4 - 1 
HNF-2369

Rev. 0

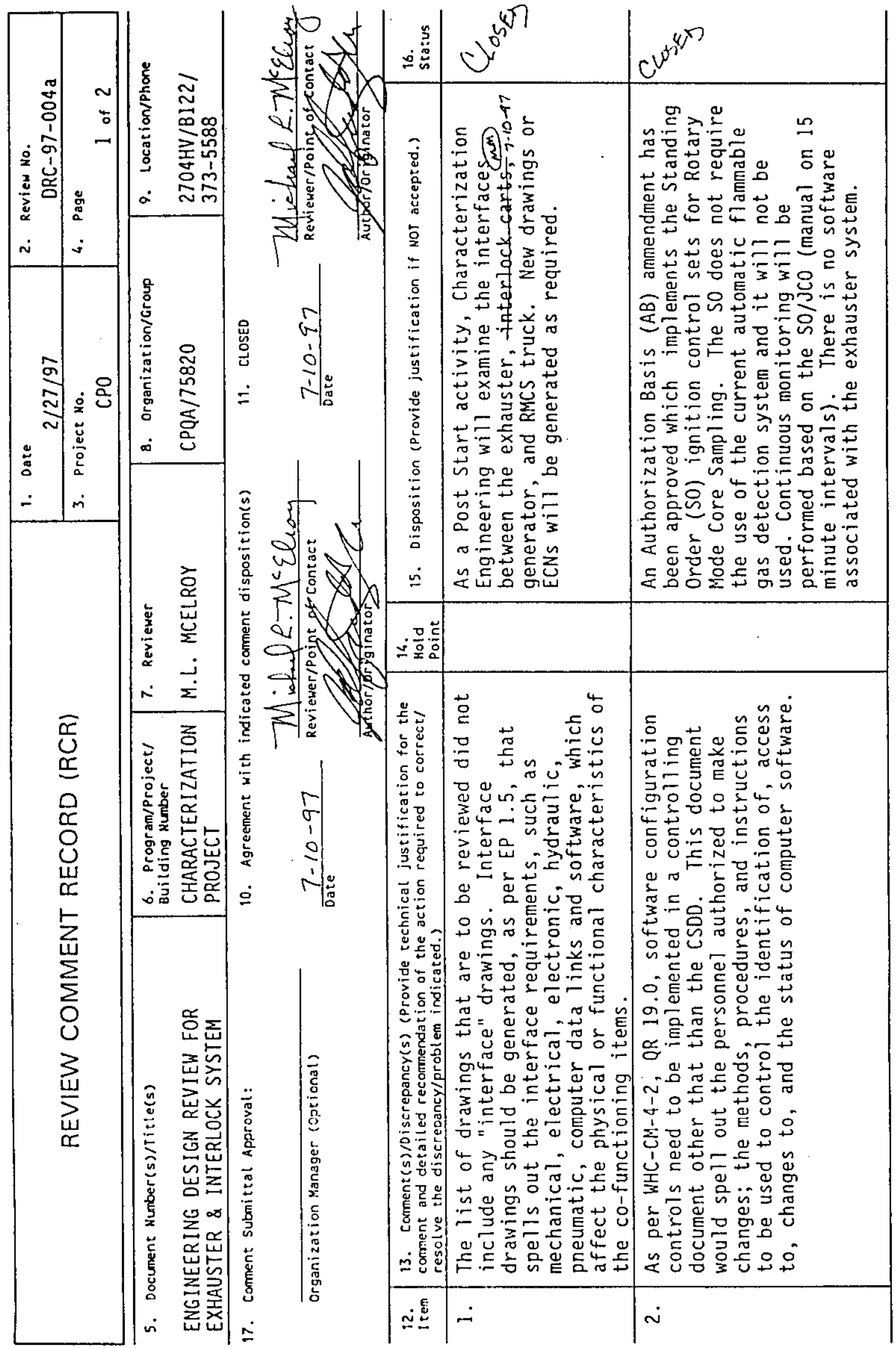

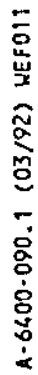

Page 5.4 - 2 
HNF-2369

Rev. 0

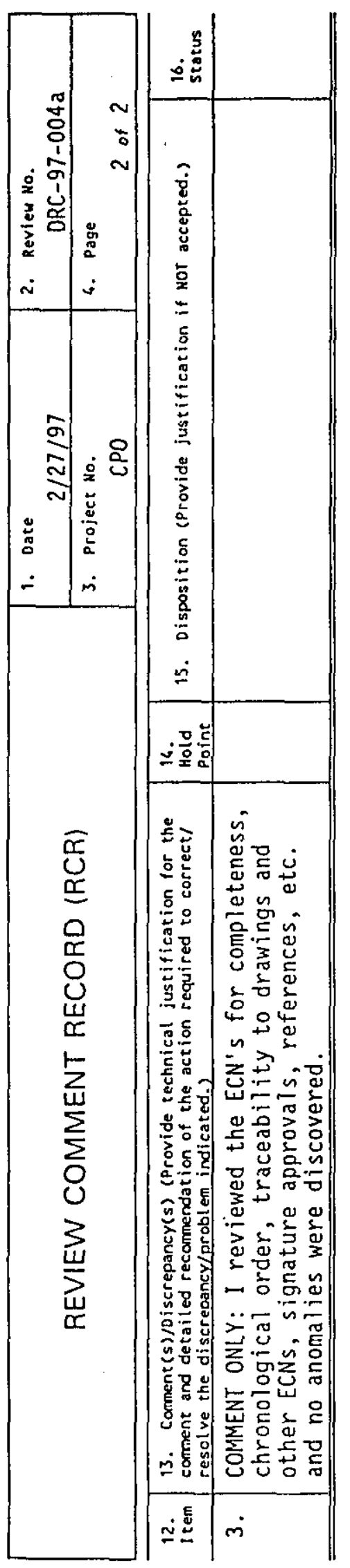

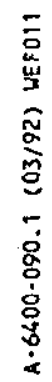

Page 5.4 - 3 


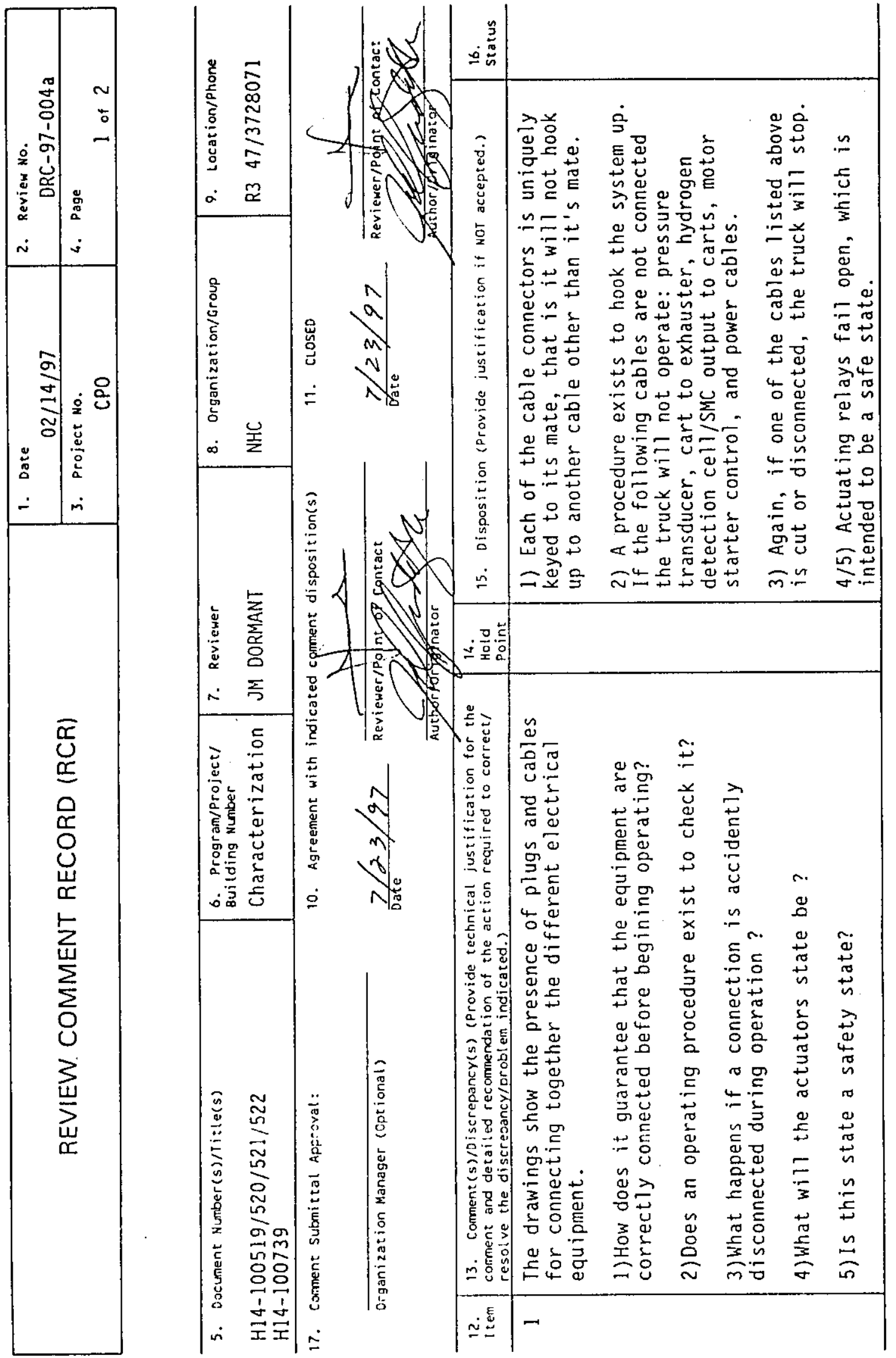

Page 5.4 - 4 


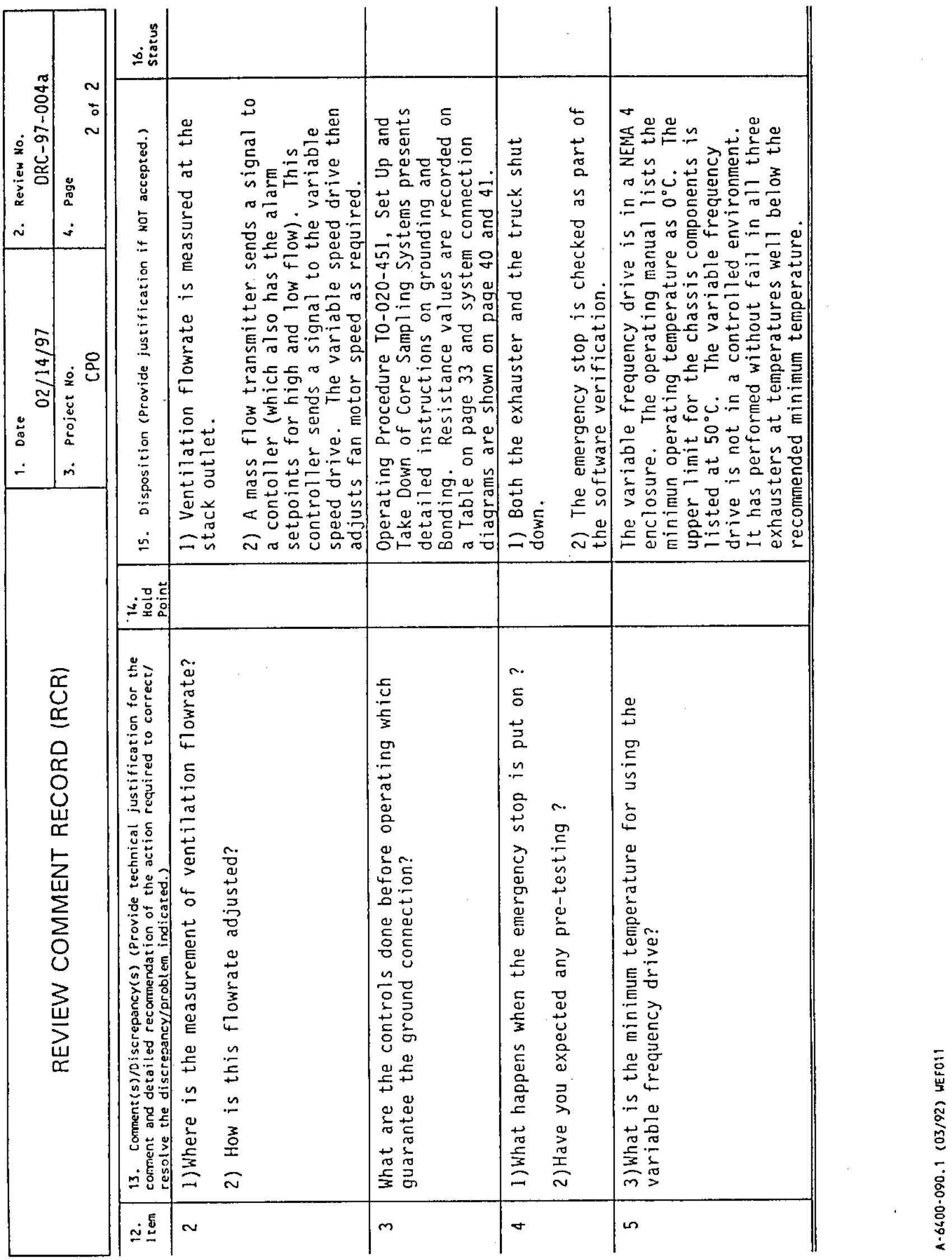




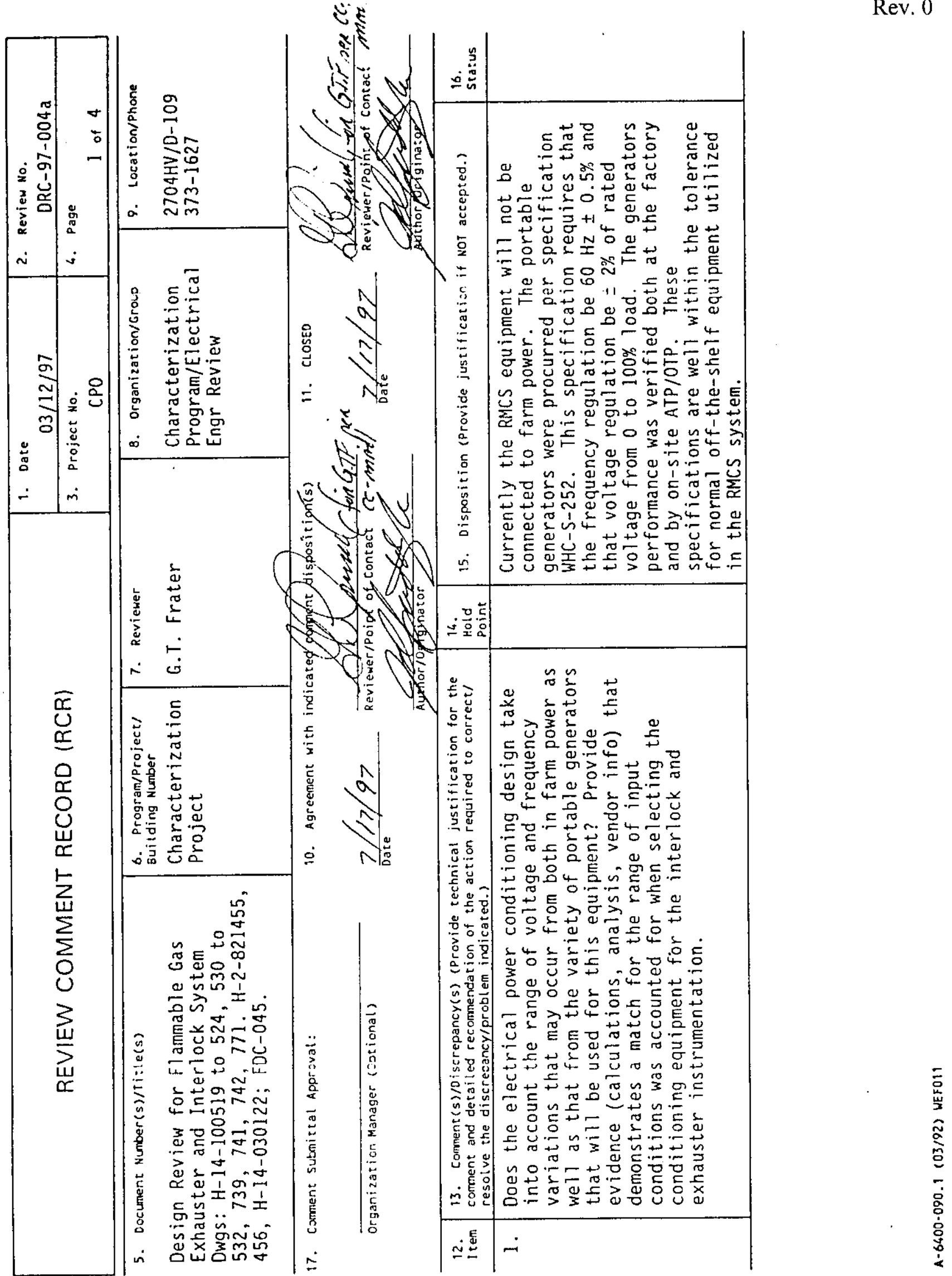

Page 5.4 - 6 


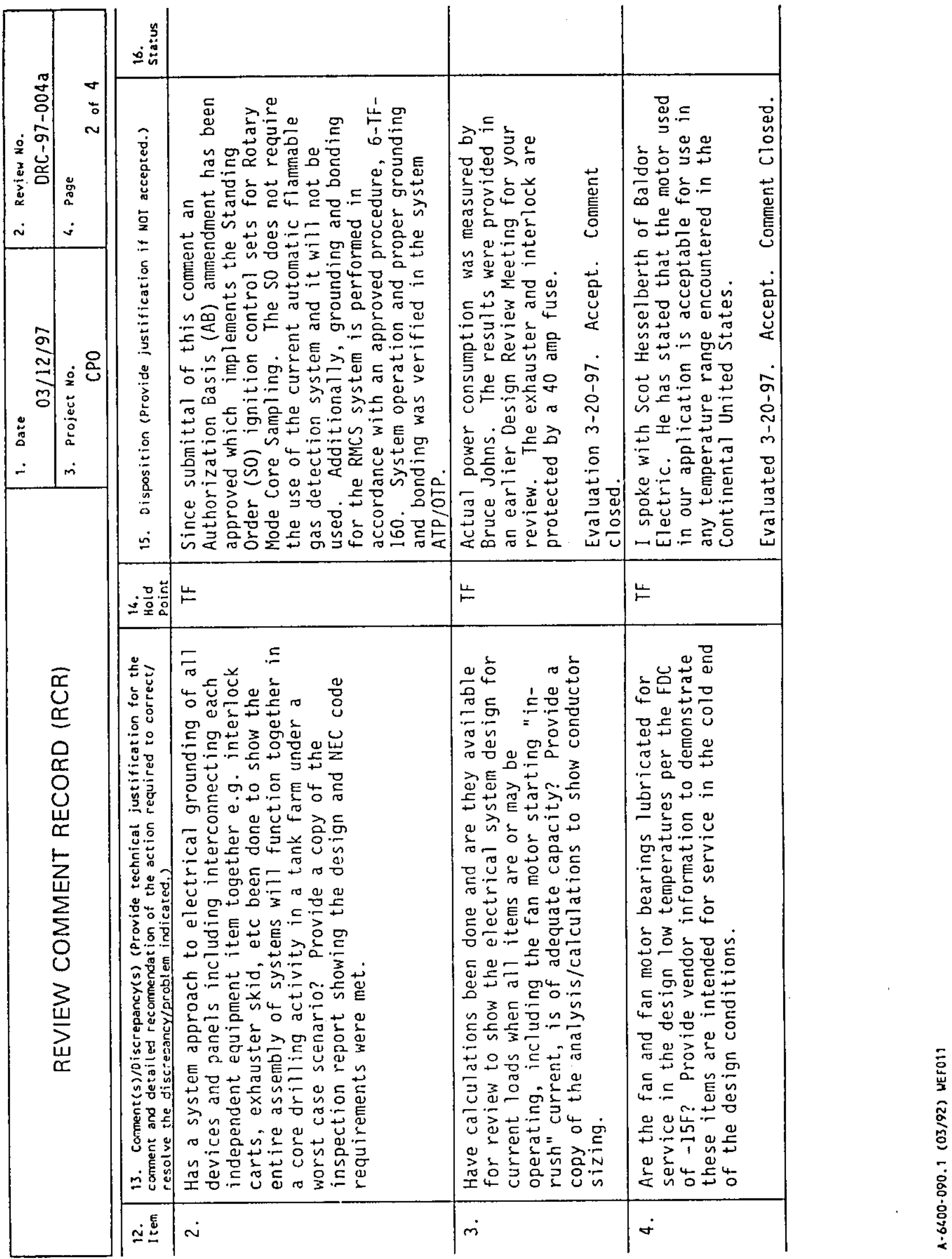




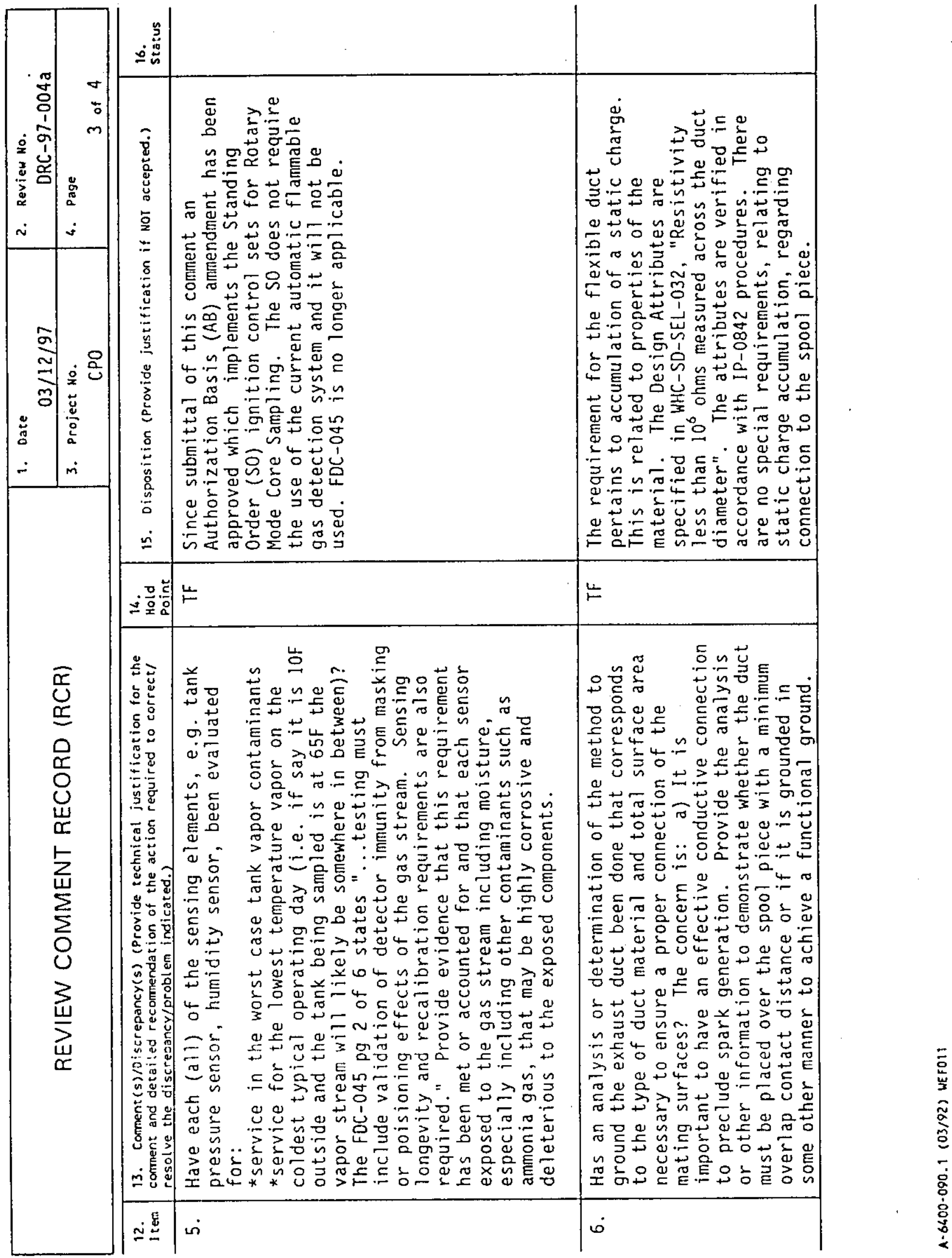


HNF-2369

Rev. 0

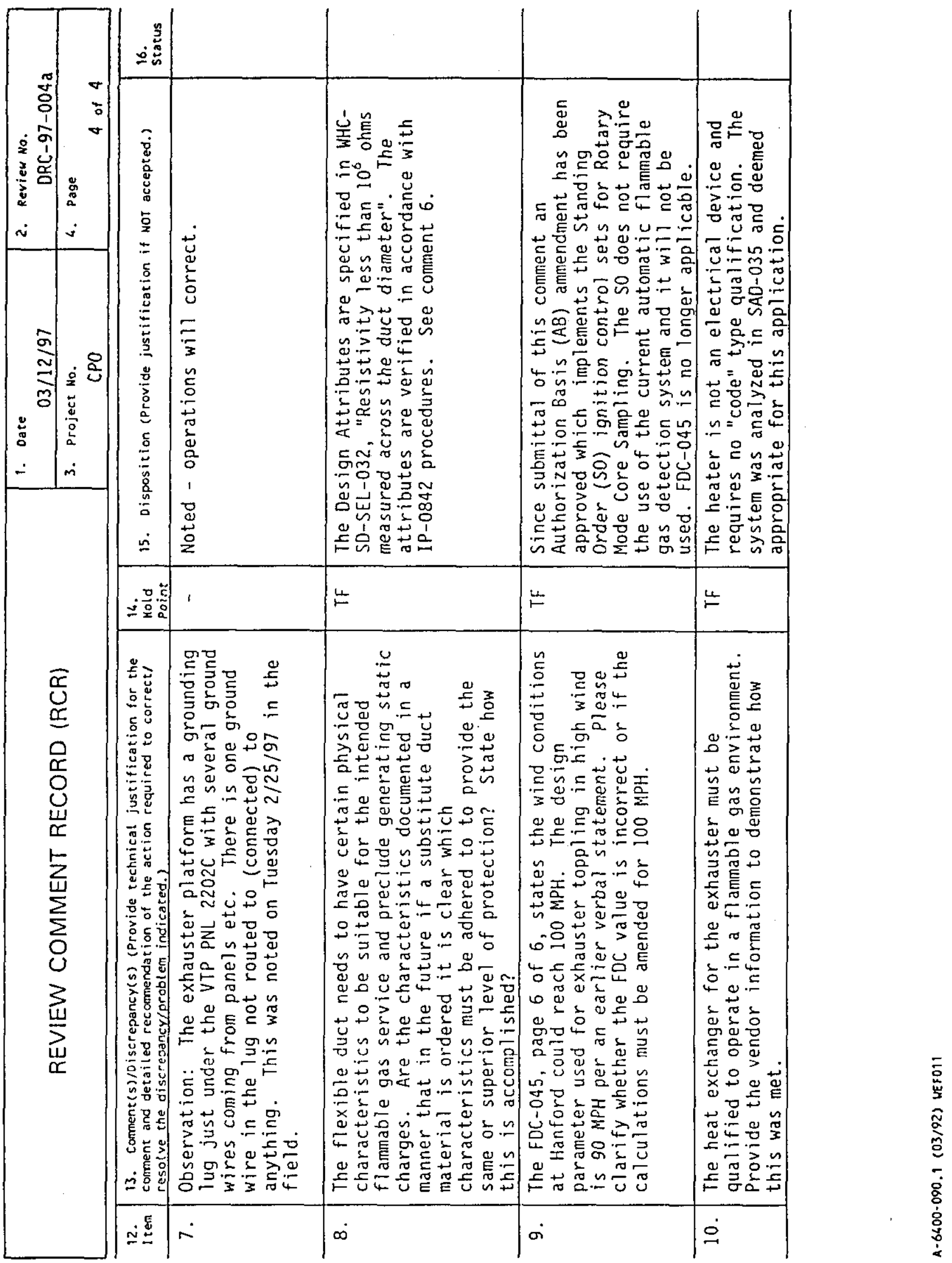

Page 5.4 - 9 
HNF-2369

Rev. 0

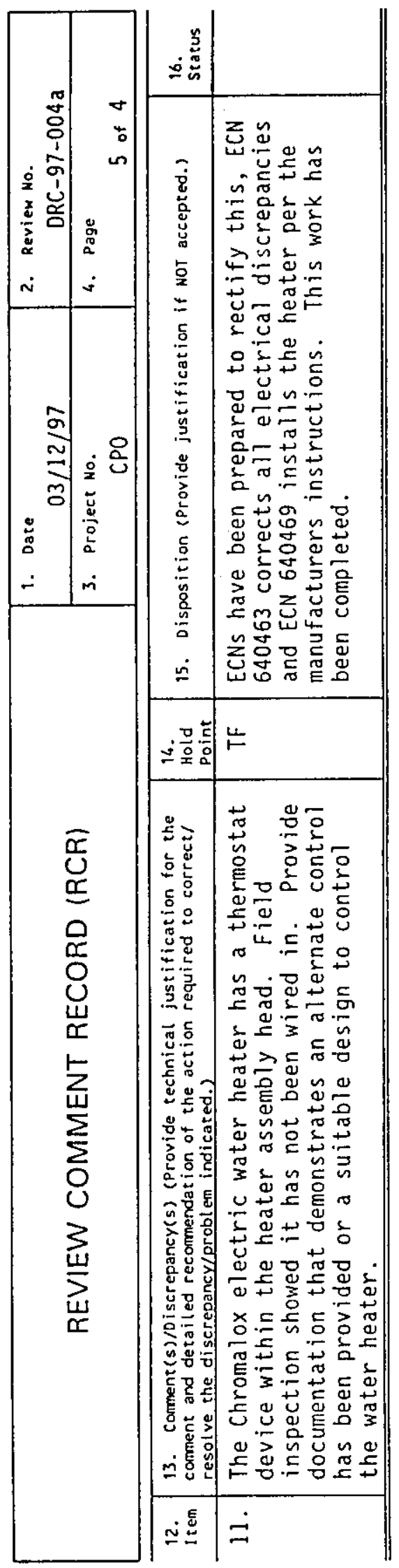




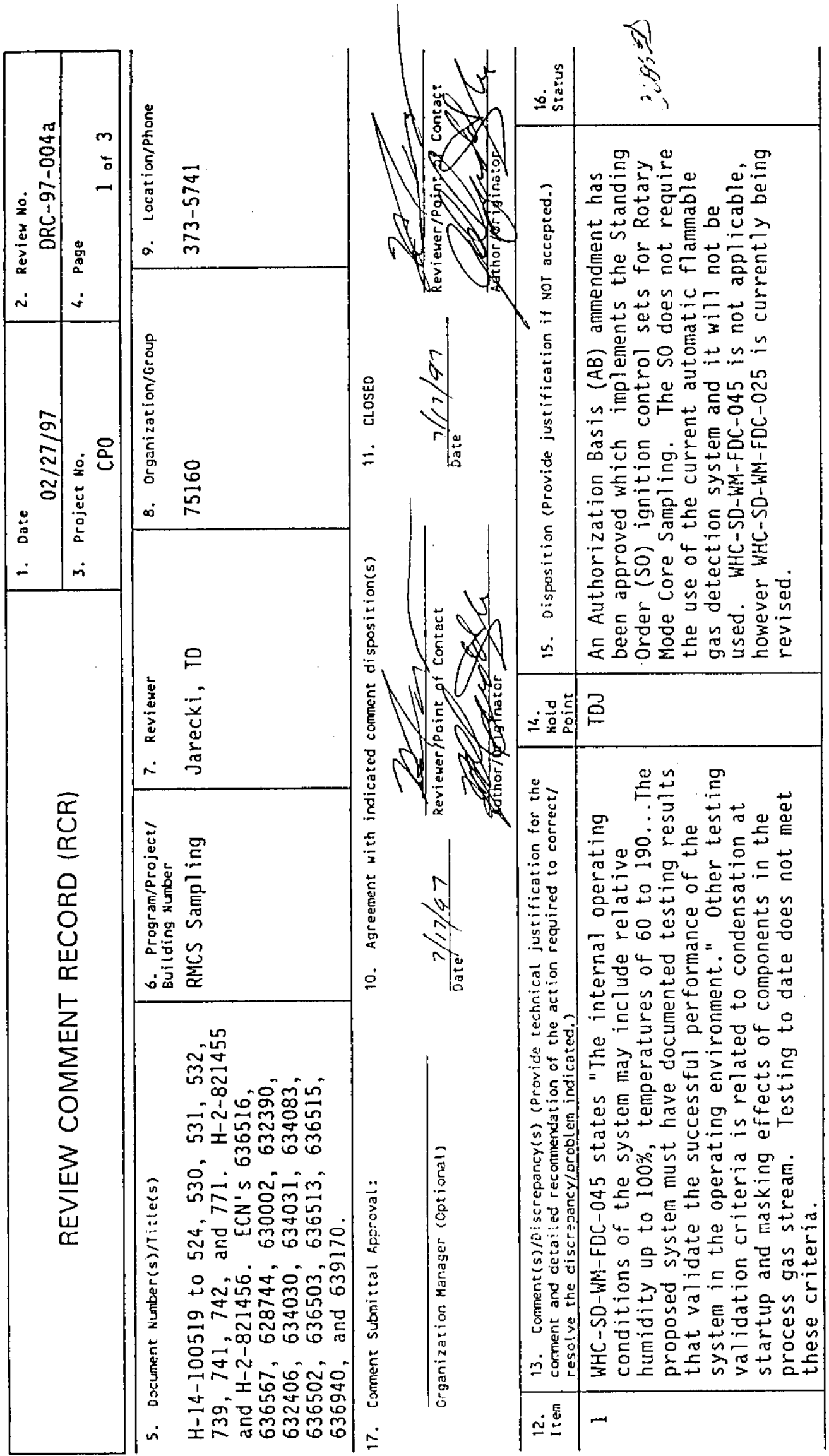

Rev. 0

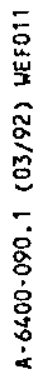




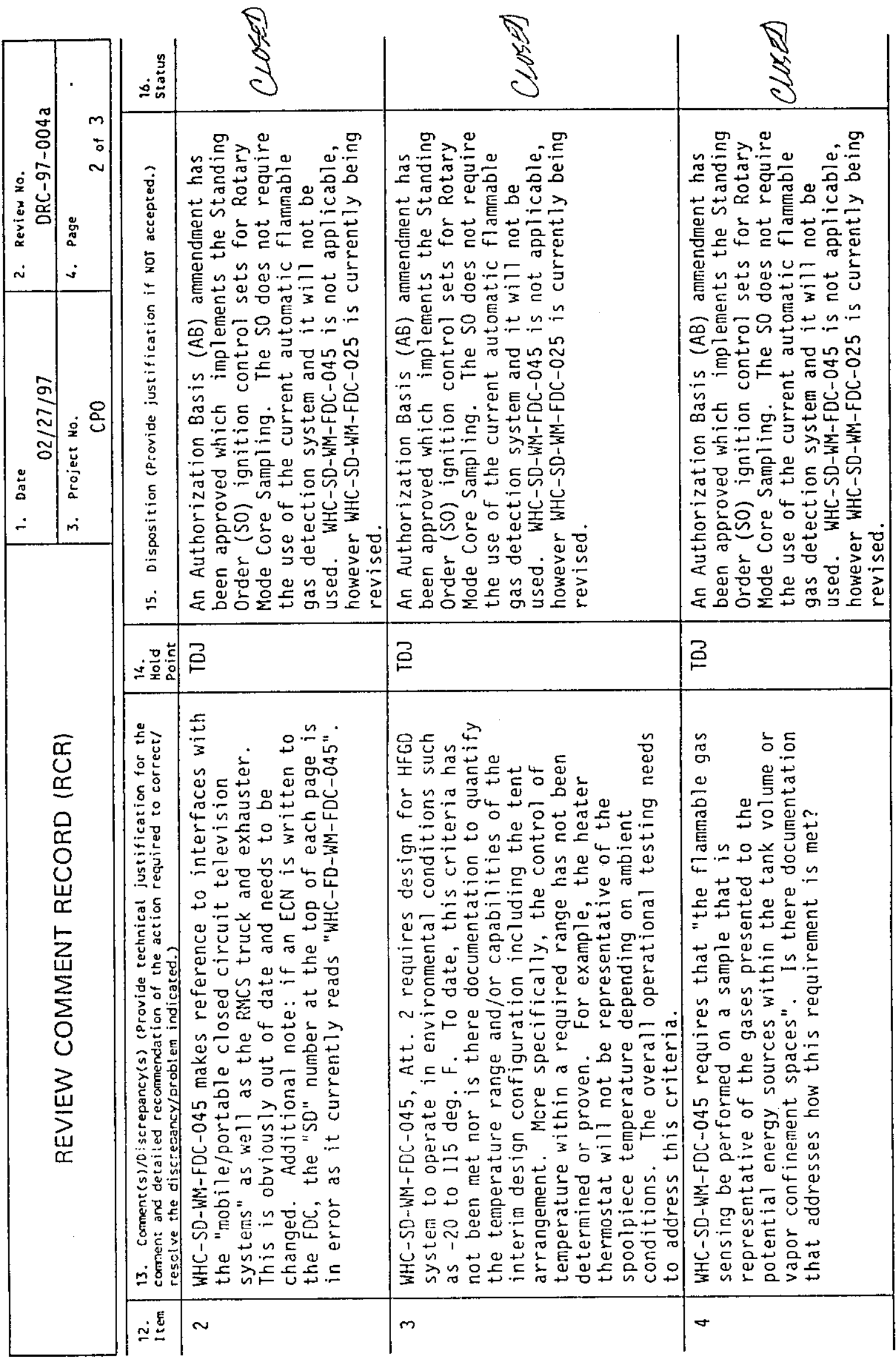


HNF-2369

Rev. 0

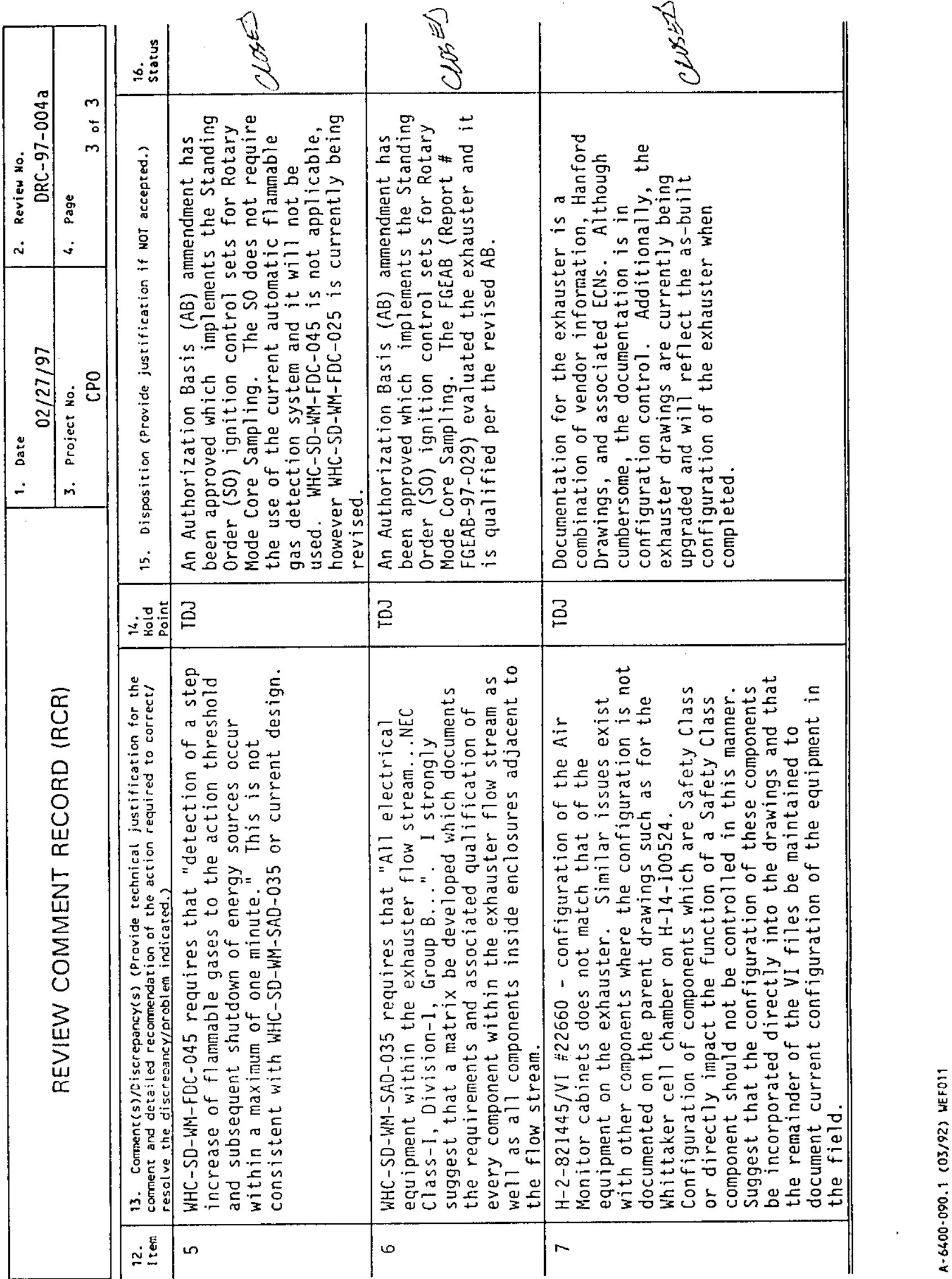


HNF-2369

Rev. 0

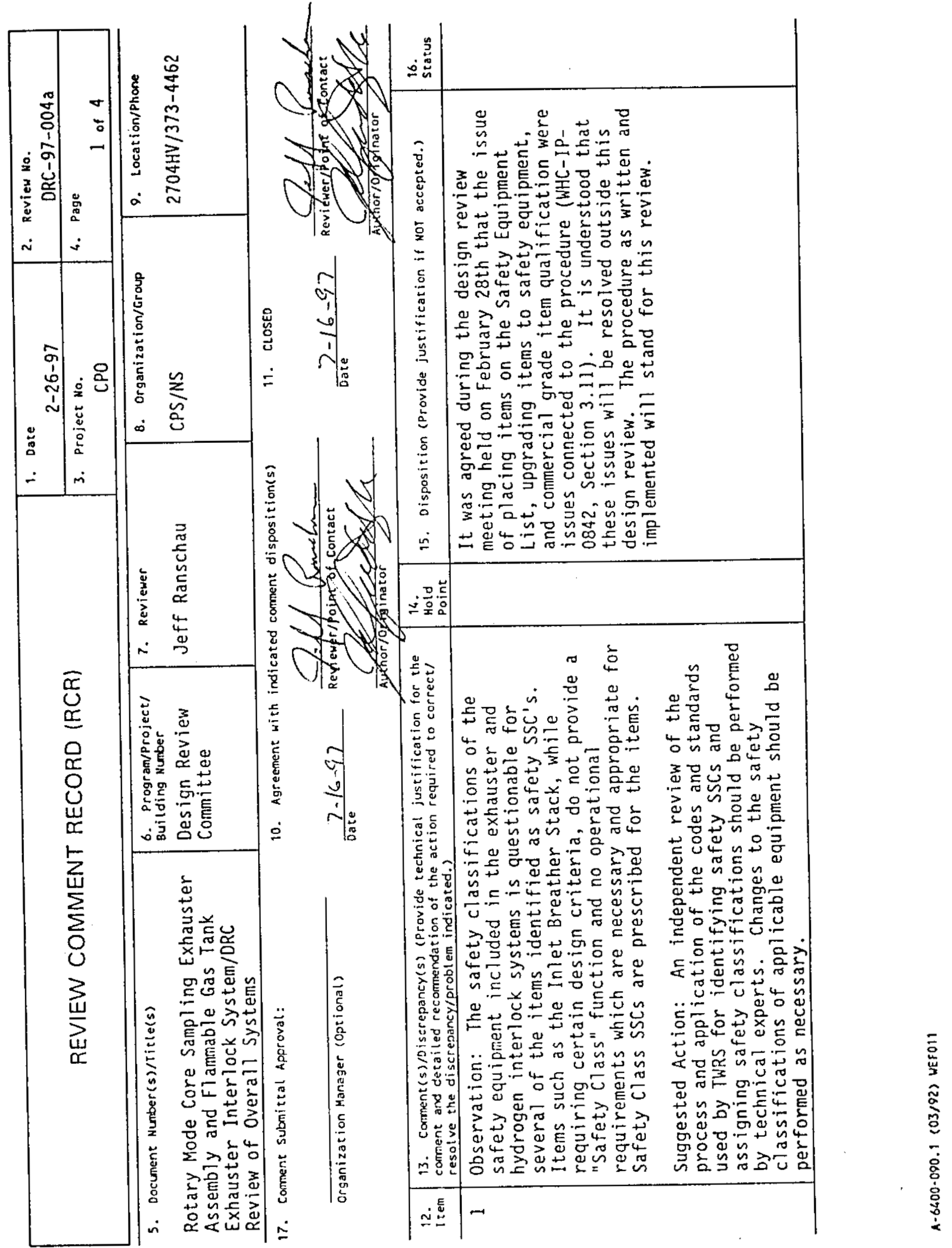

Page 5.4 - 14 


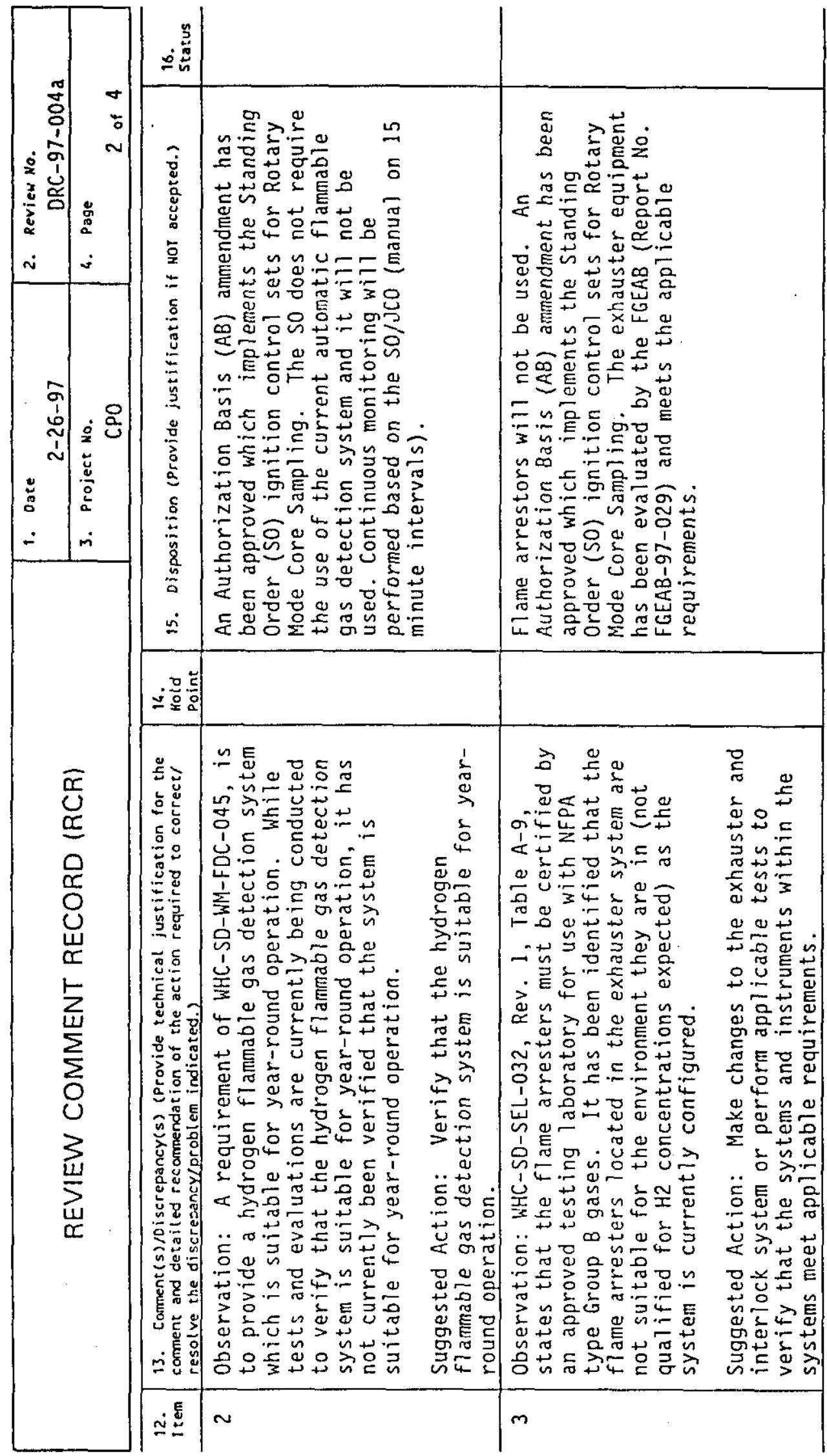


HNF-2369

Rev. 0

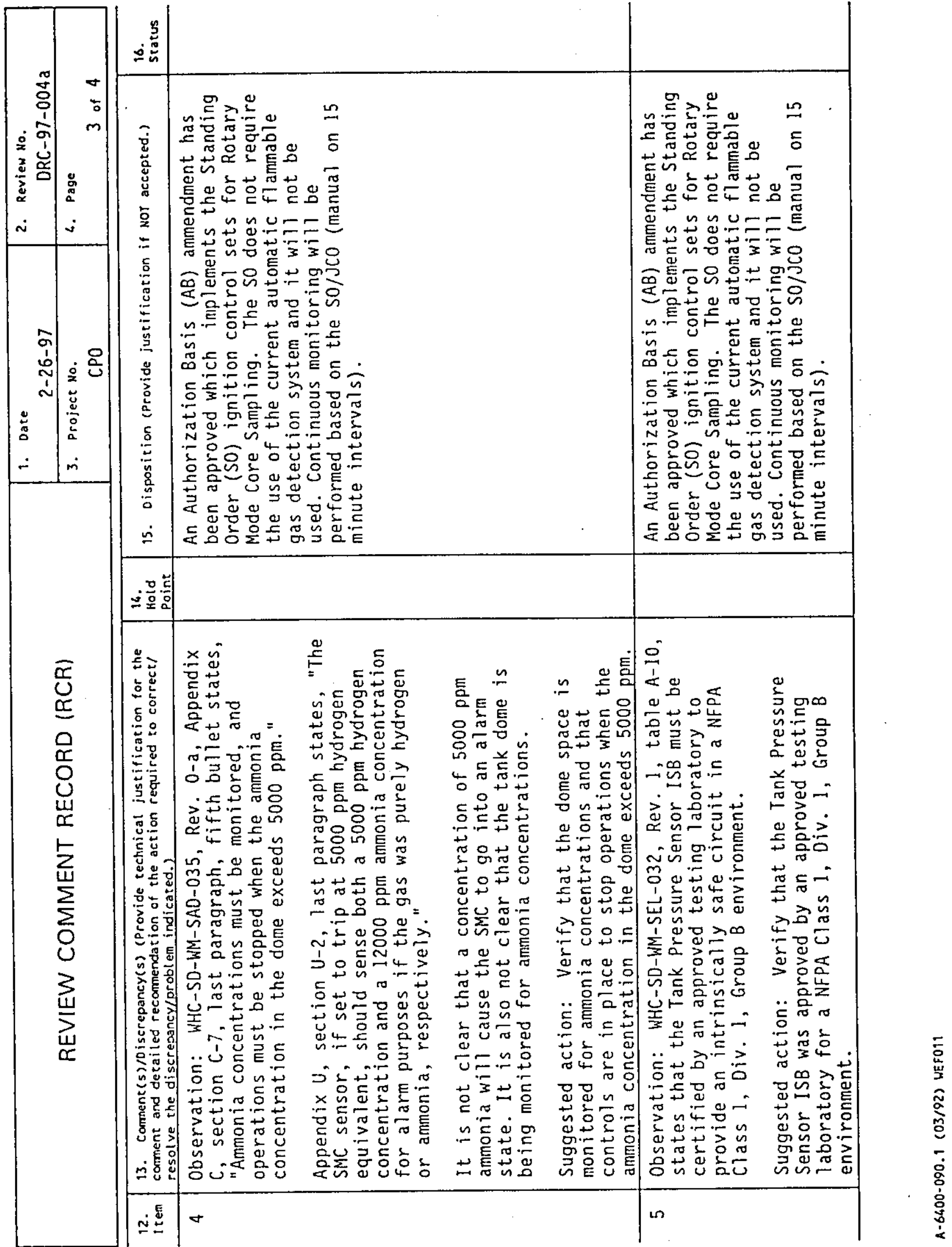

Page $5.4-16$ 


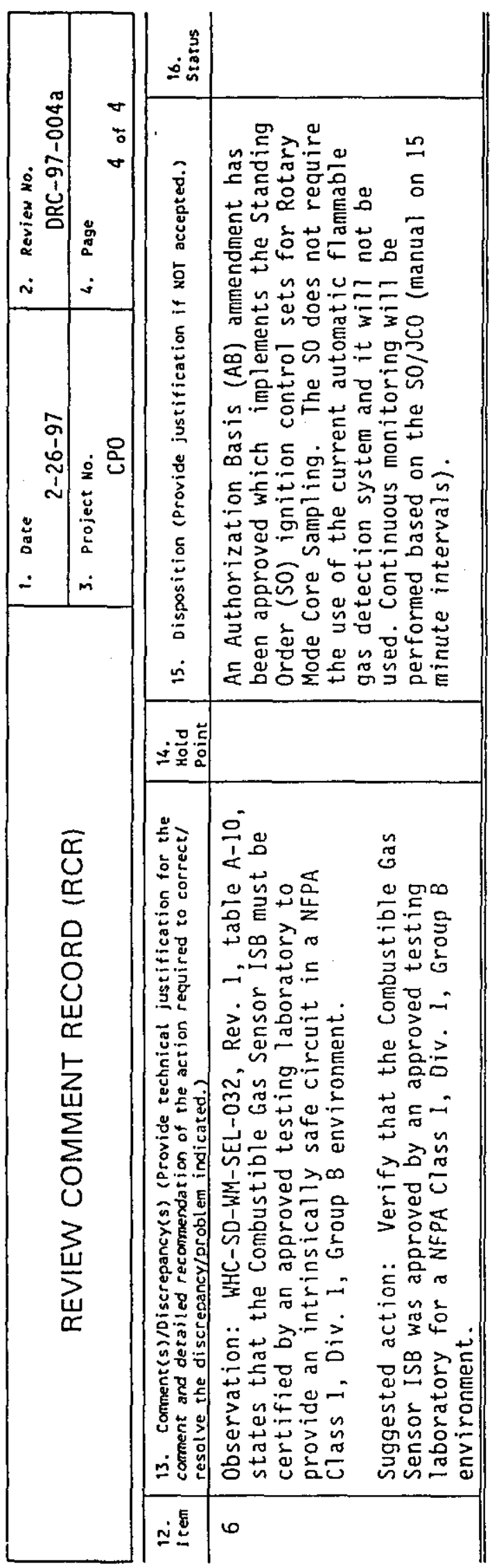


HNF-2369

Rev. 0

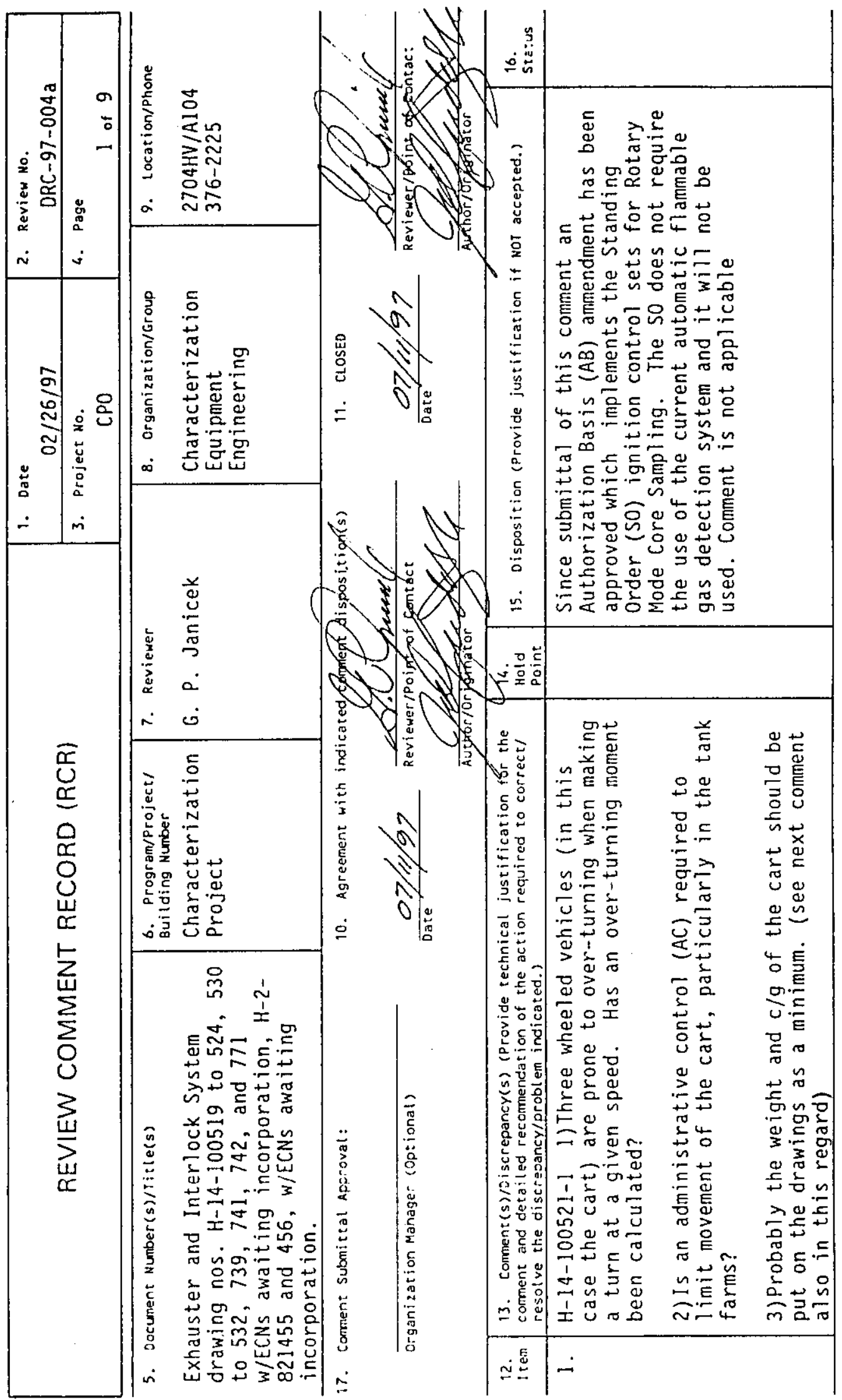


HNF-2369

Rev. 0

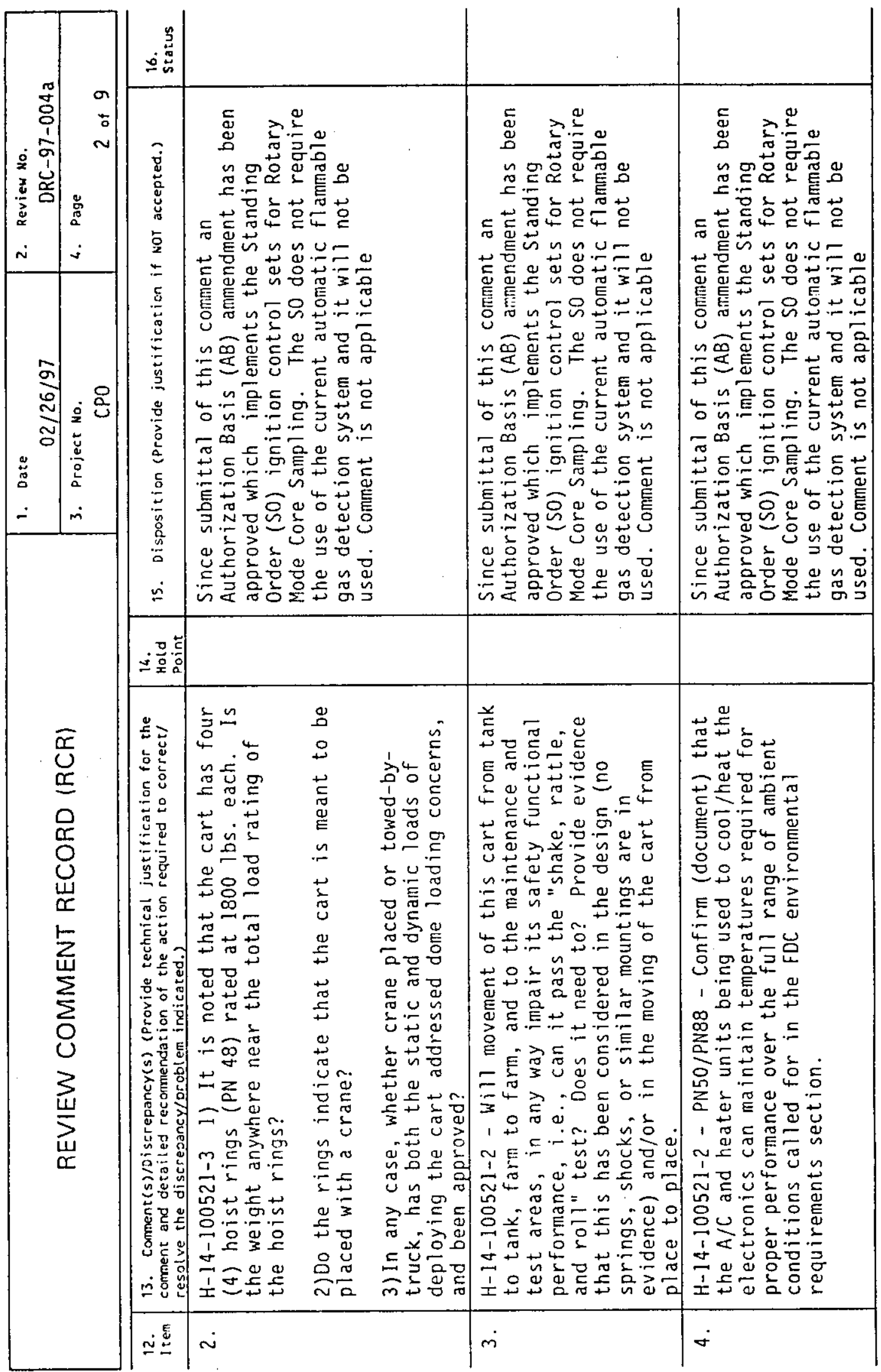

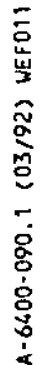


HNF-2369

Rev. 0

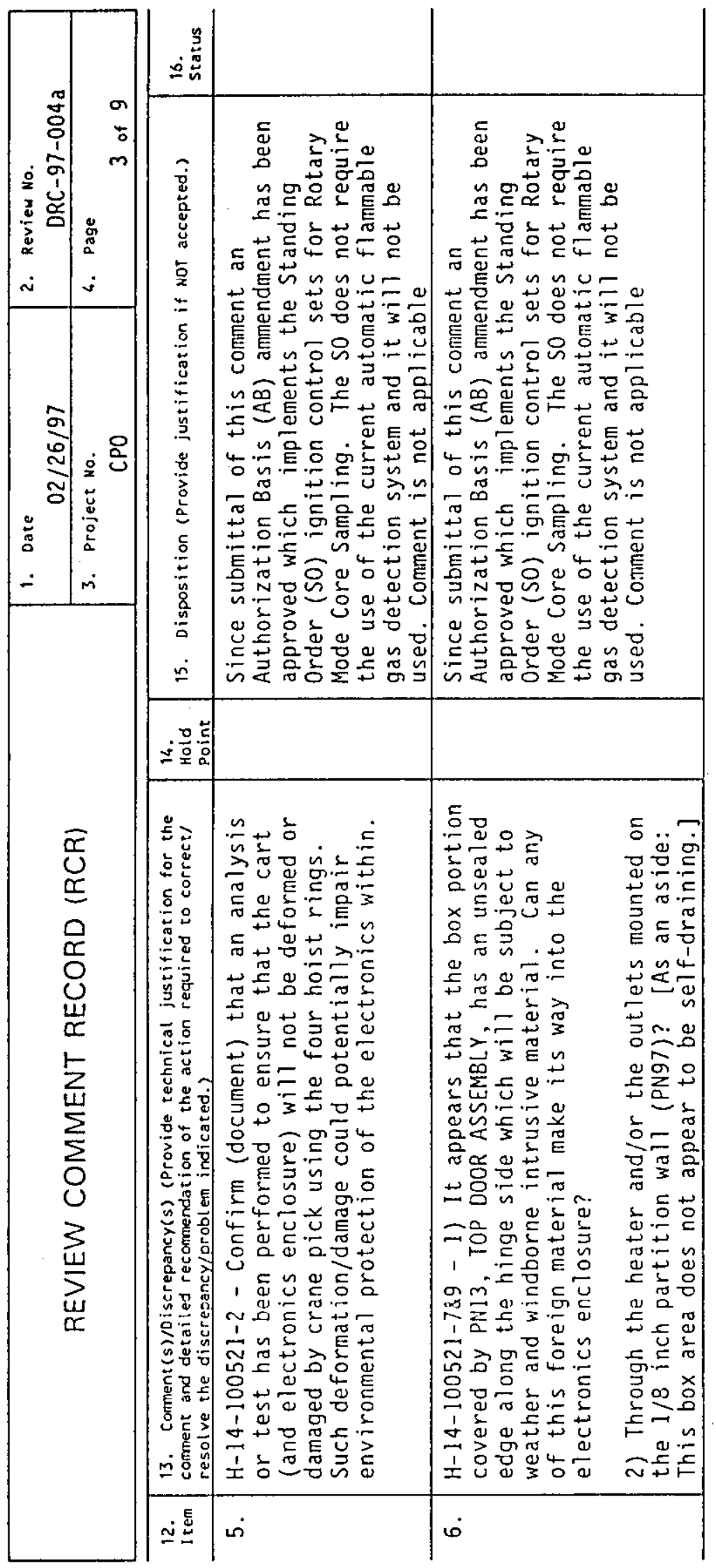




\begin{tabular}{|c|c|c|c|c|}
\hline & & 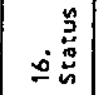 & & \\
\hline 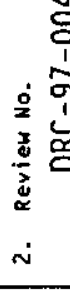 & $\begin{array}{l}\text { : } \\
\text { ฌू } \\
\text { : }\end{array}$ & 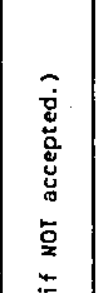 & 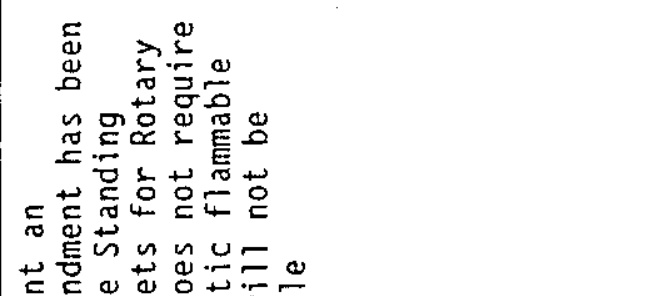 & 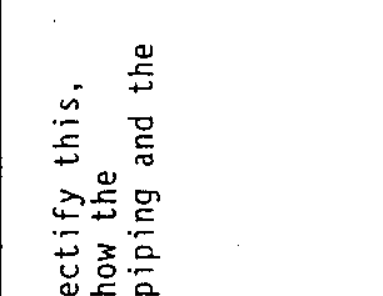 \\
\hline$\frac{\tilde{\sigma}}{\check{c}}$ & 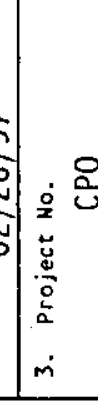 & 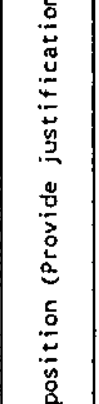 & 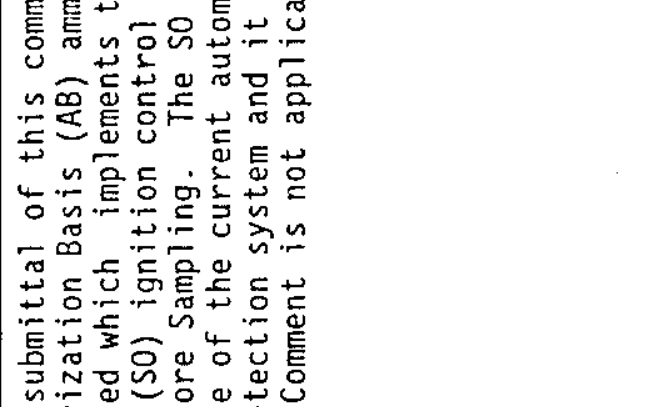 & 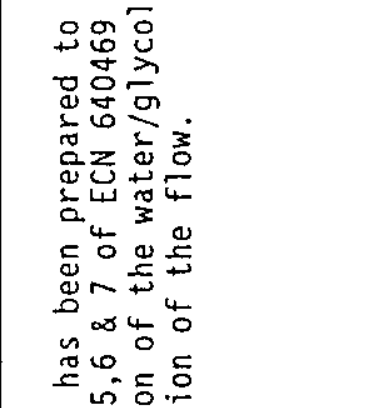 \\
\hline & \multirow{4}{*}{ 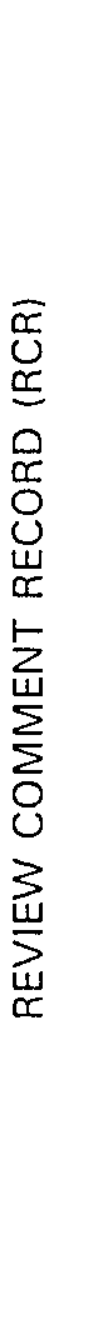 } & $\begin{array}{l}\frac{n}{a} \\
\dot{n}\end{array}$ & 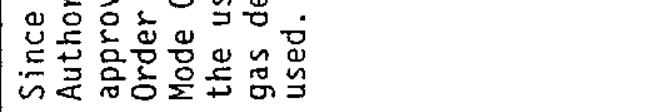 & 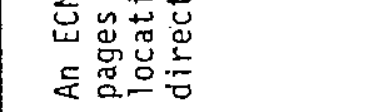 \\
\hline & & 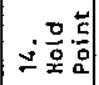 & & \\
\hline & & 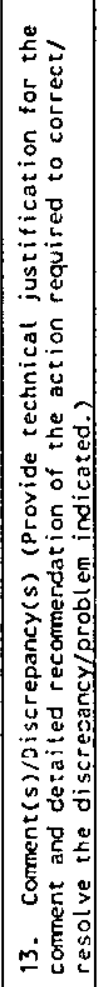 & 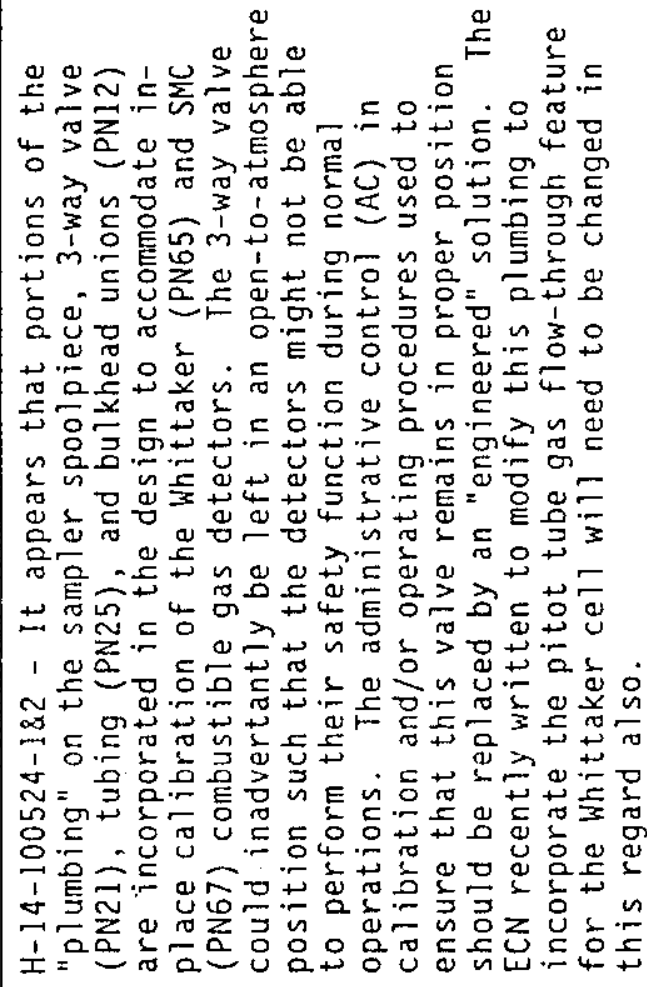 & 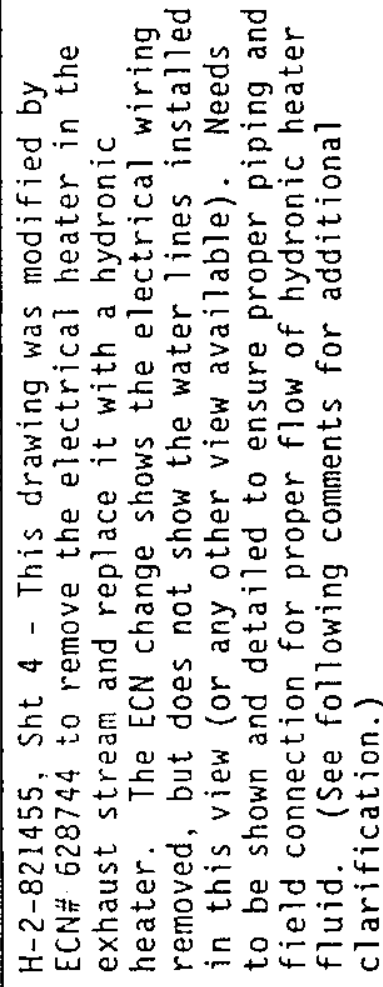 \\
\hline & & $\stackrel{\text { 量 }}{ }$ & 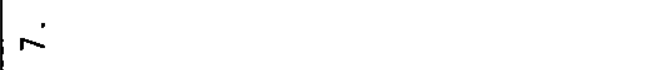 & $\infty^{\circ}$ \\
\hline
\end{tabular}




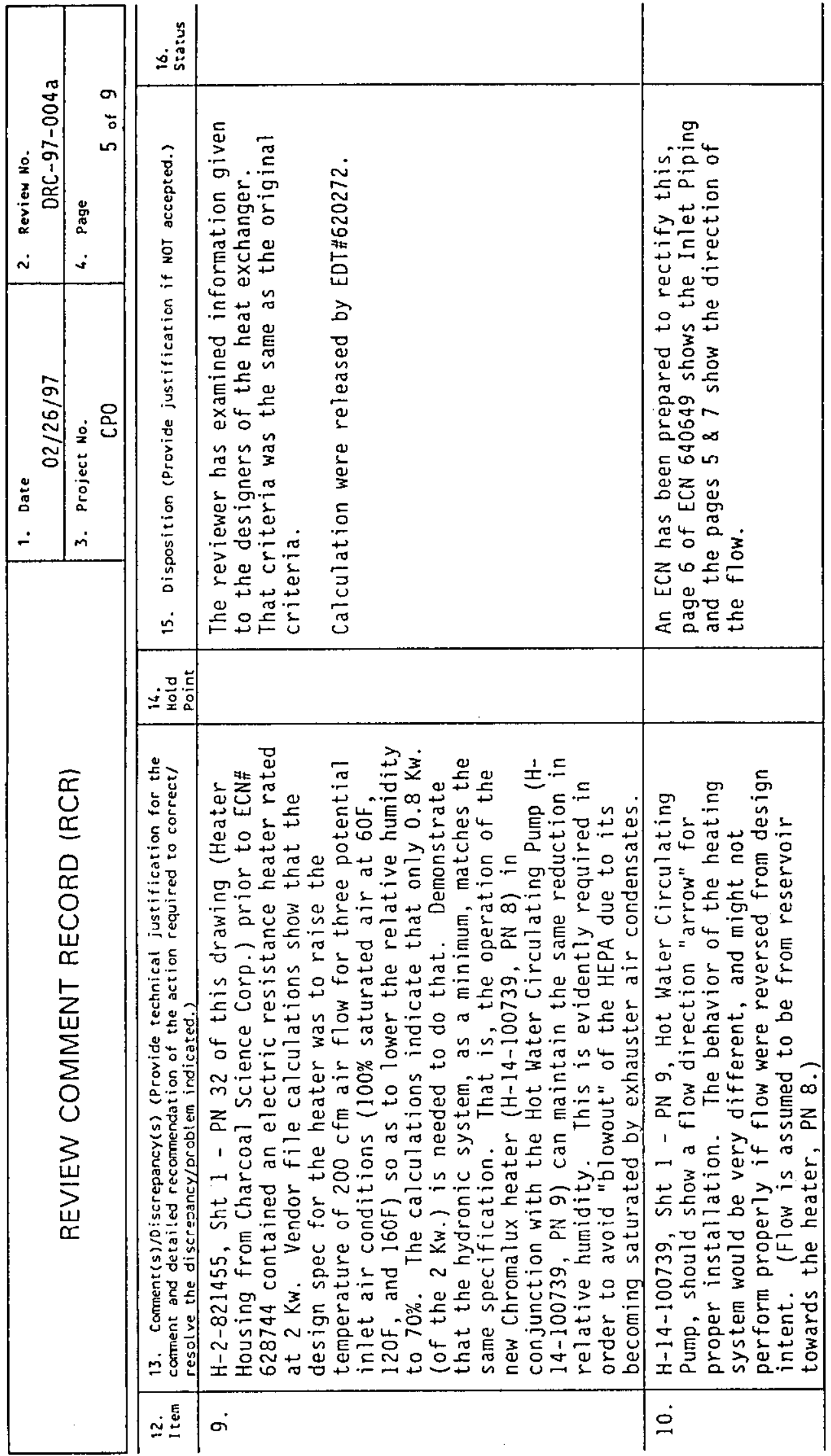




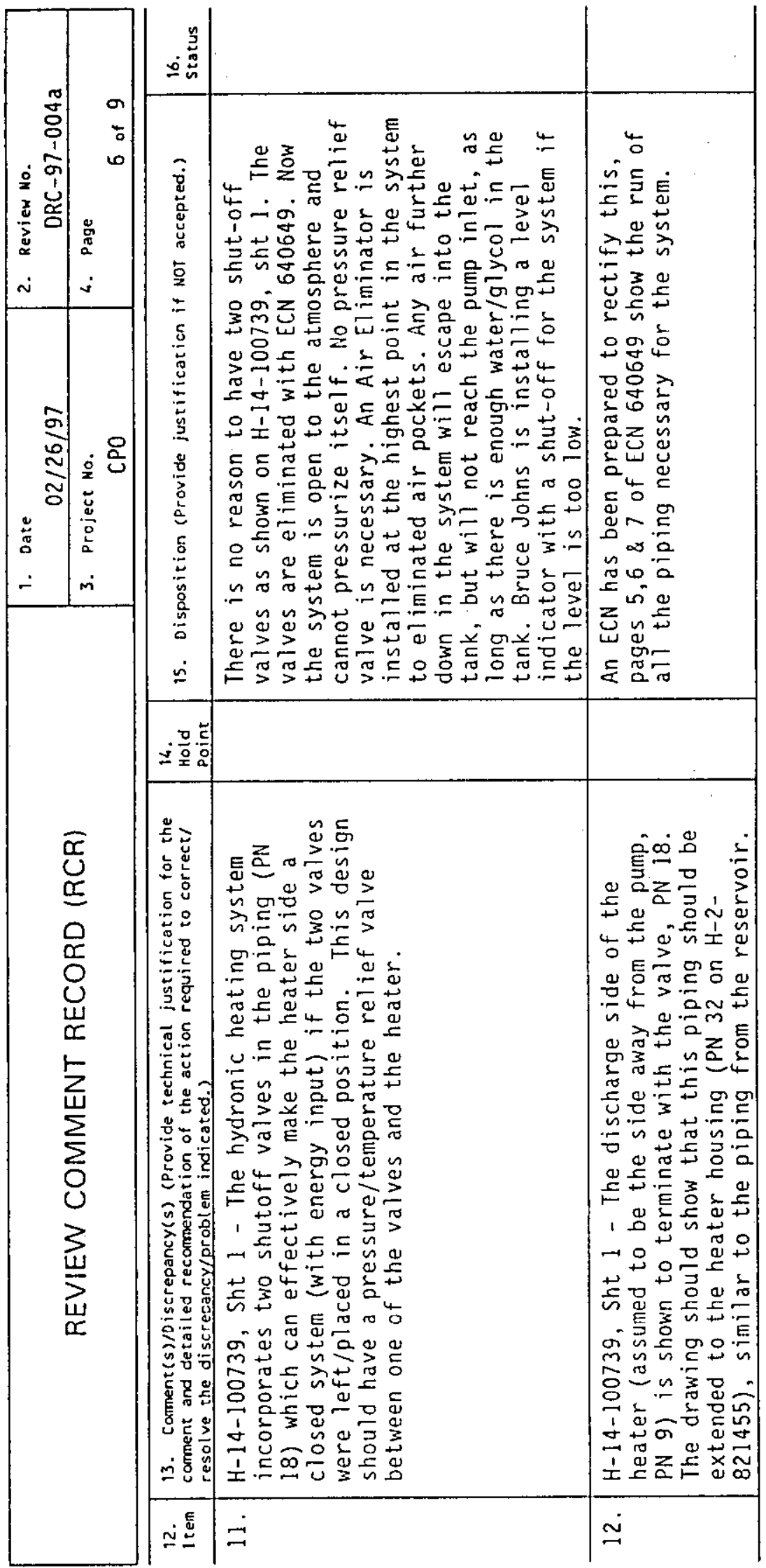




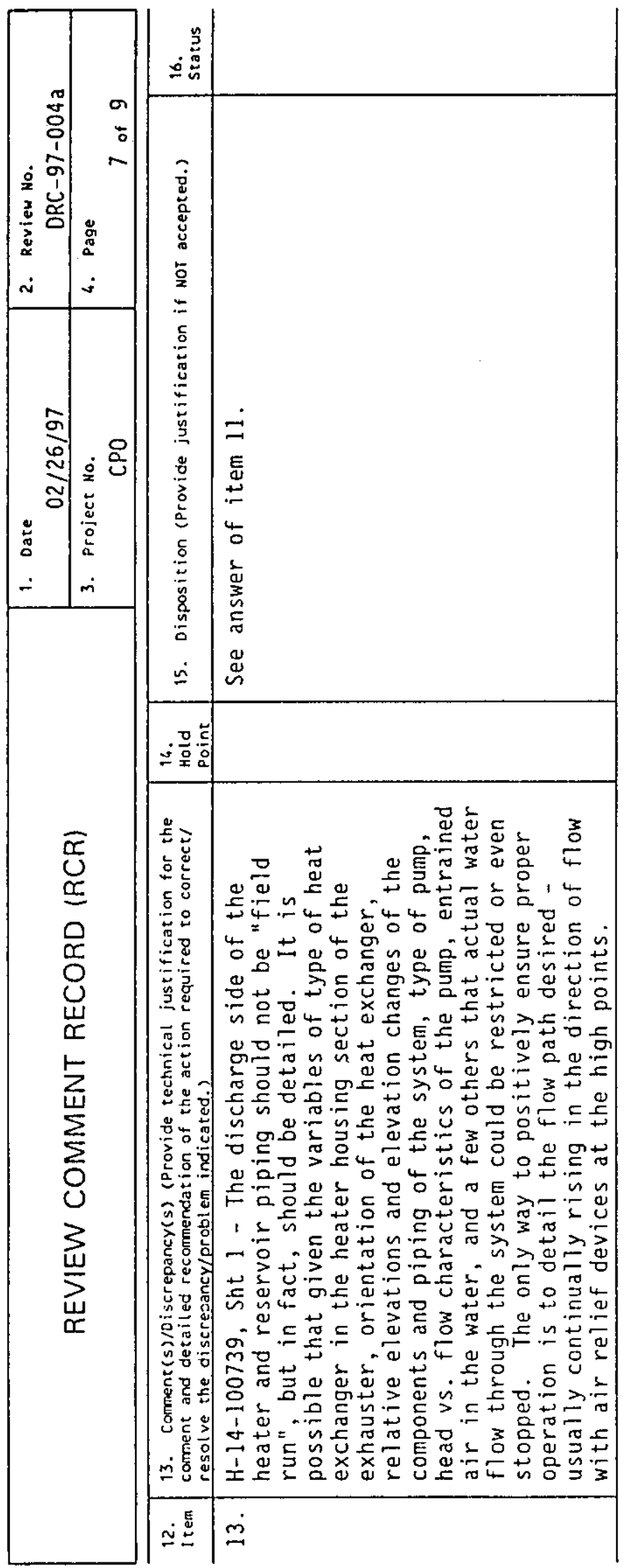




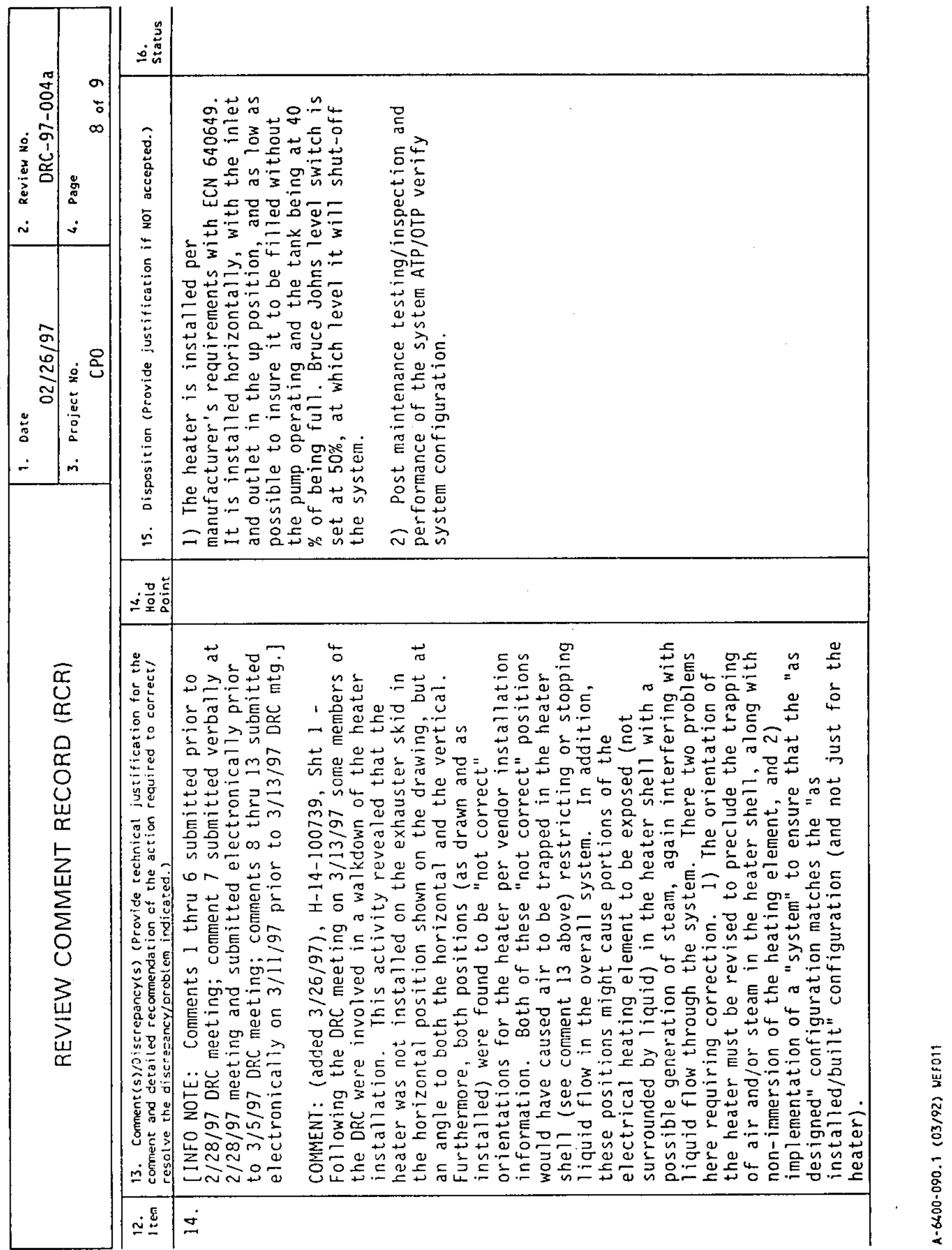




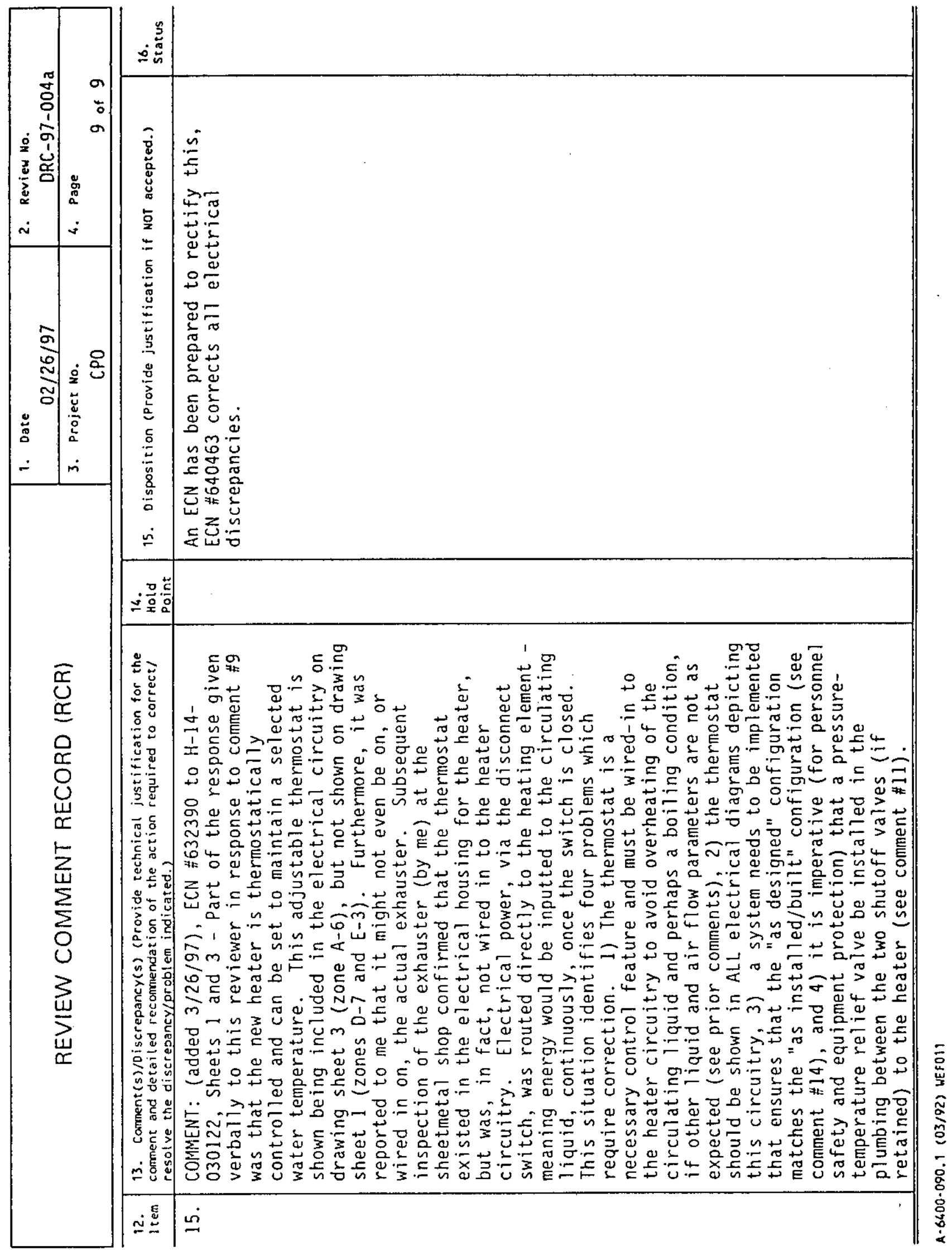


HNF-2369

Rev. 0

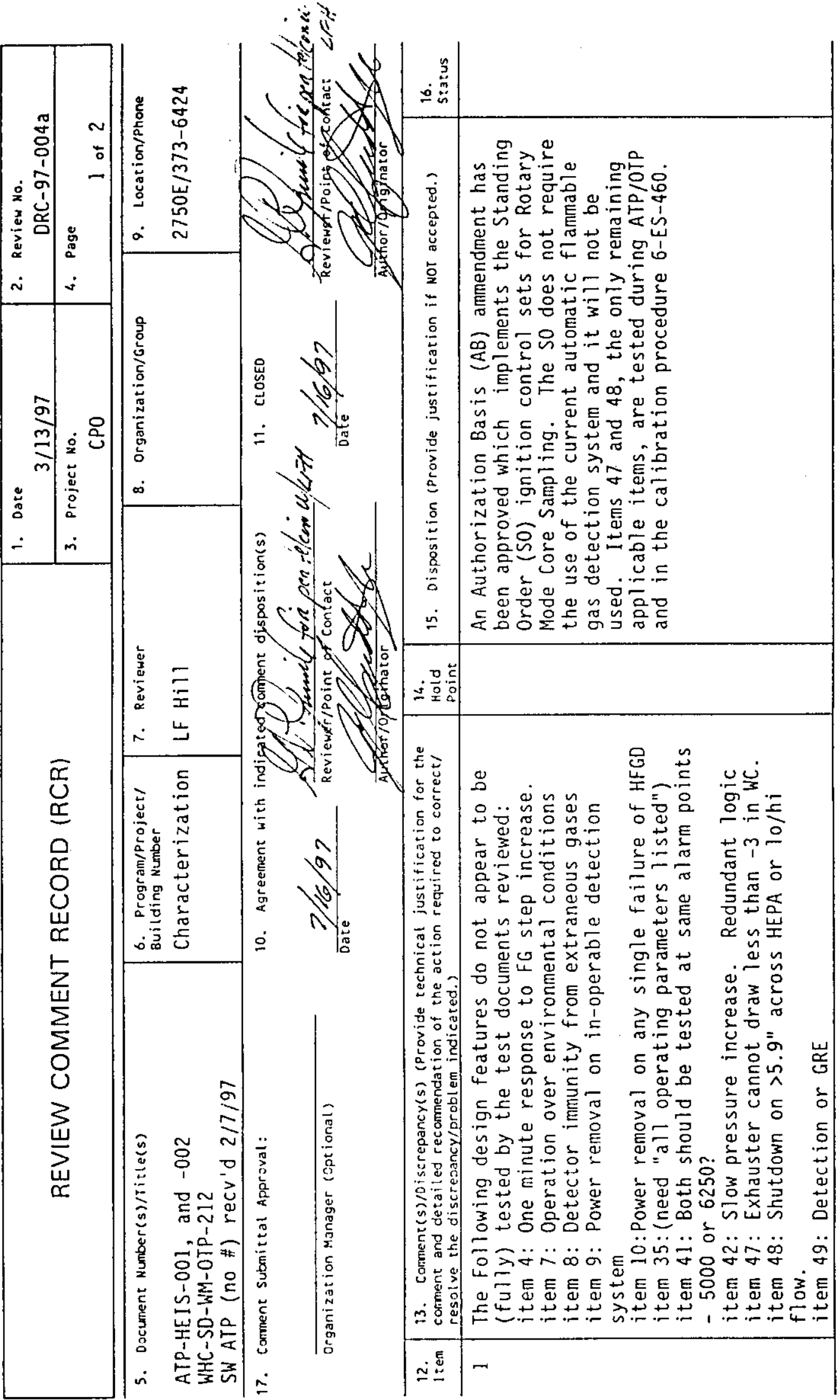

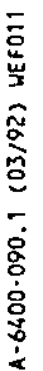

Page $5.4-27$ 
HNF-2369

Rev. 0

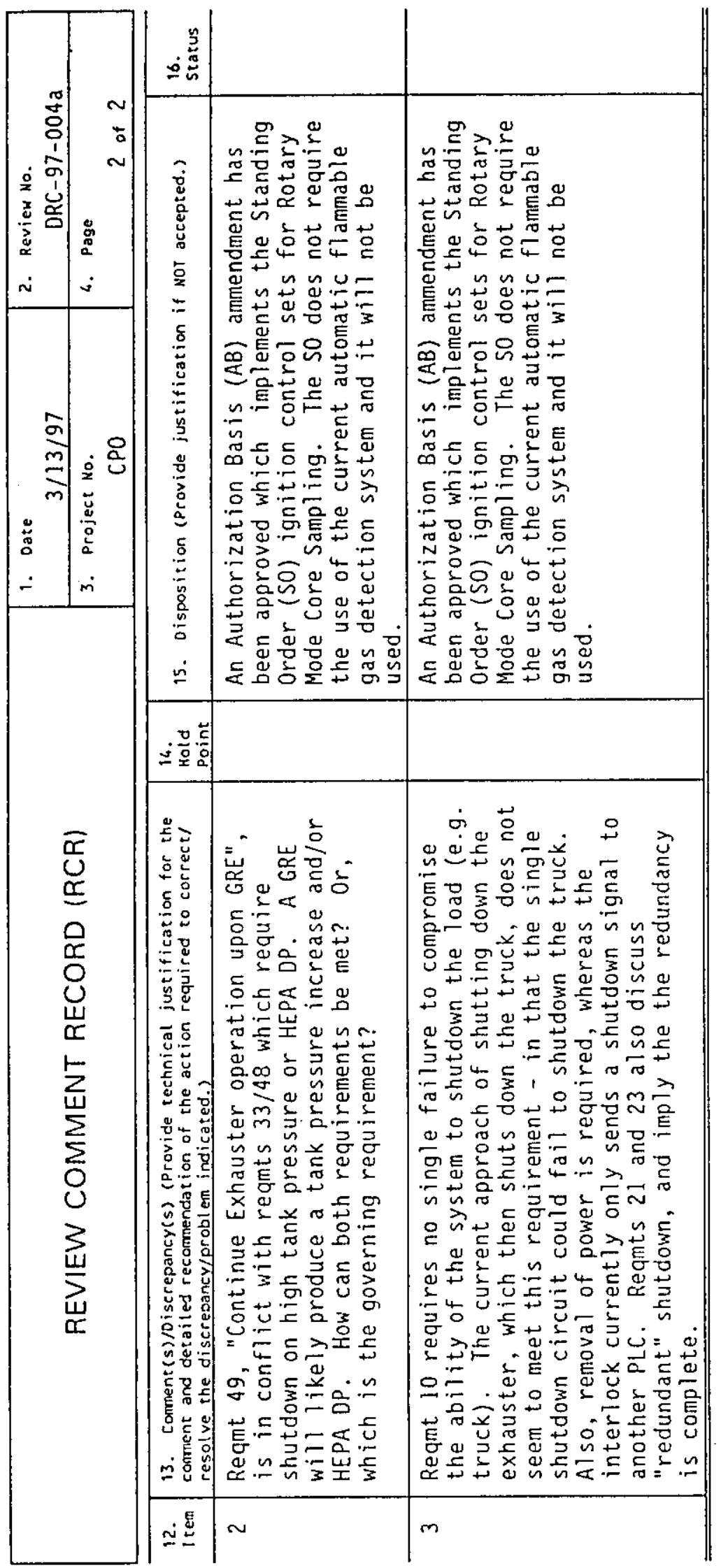




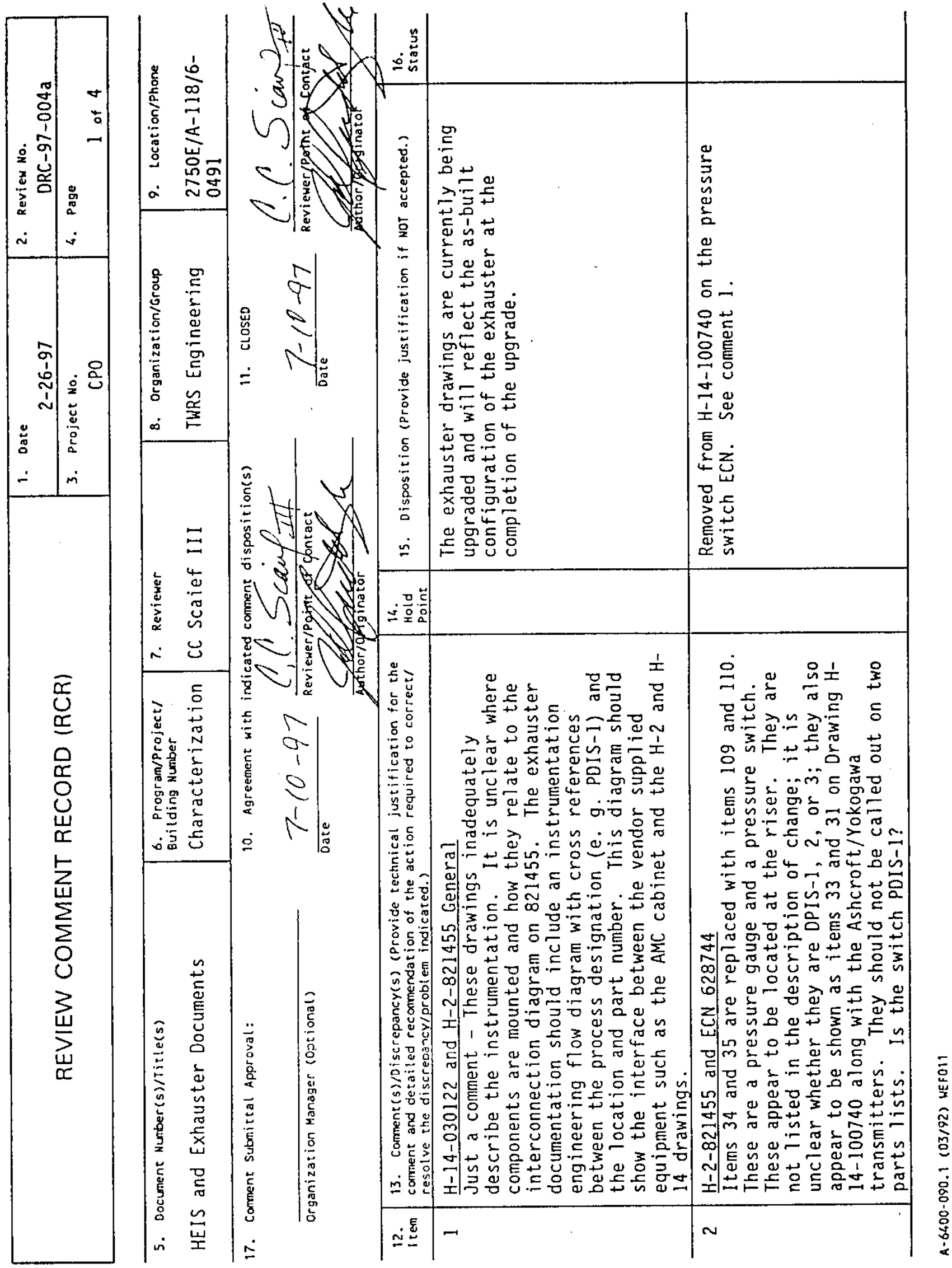


HNF-2369

Rev. 0

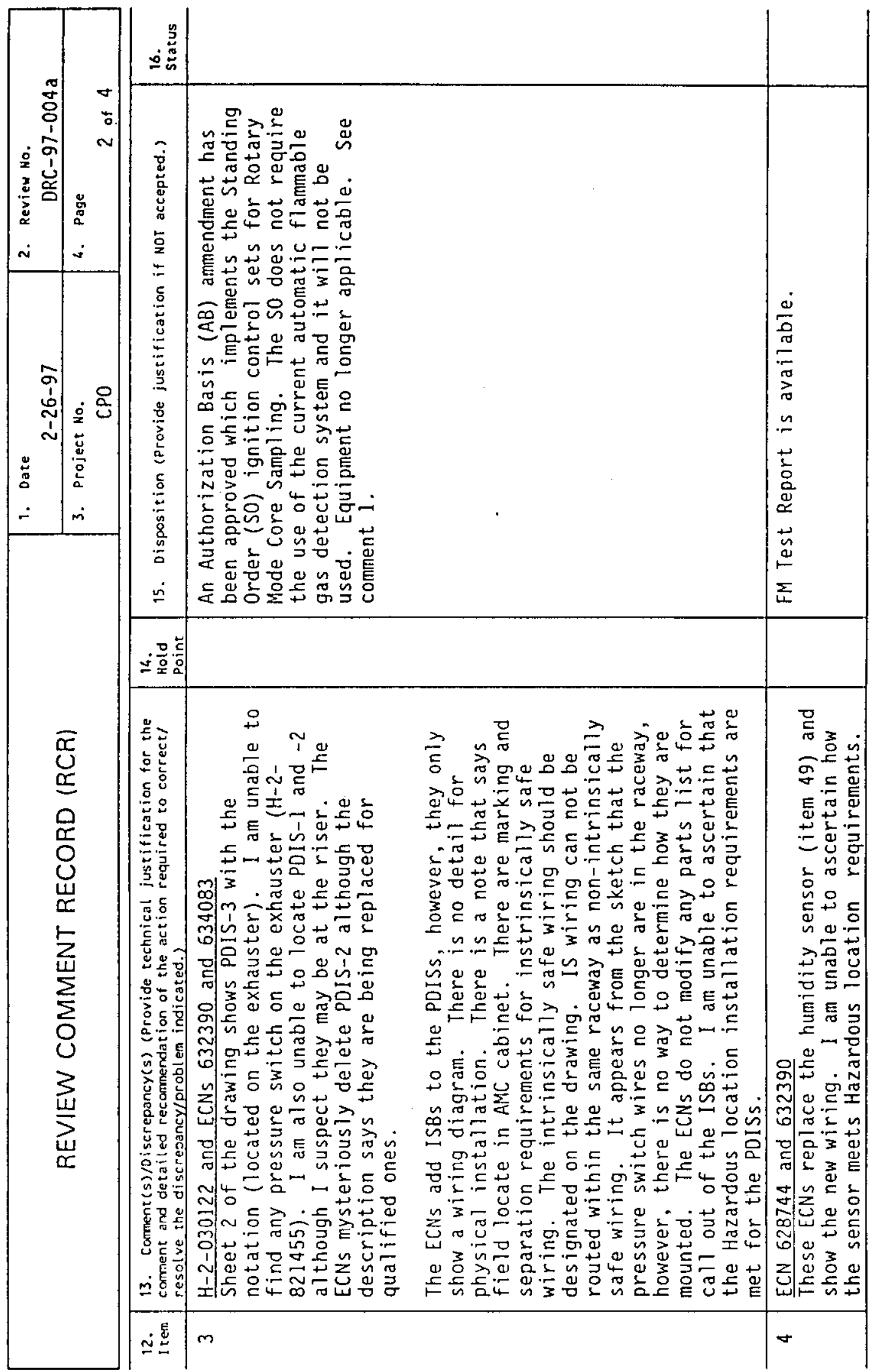




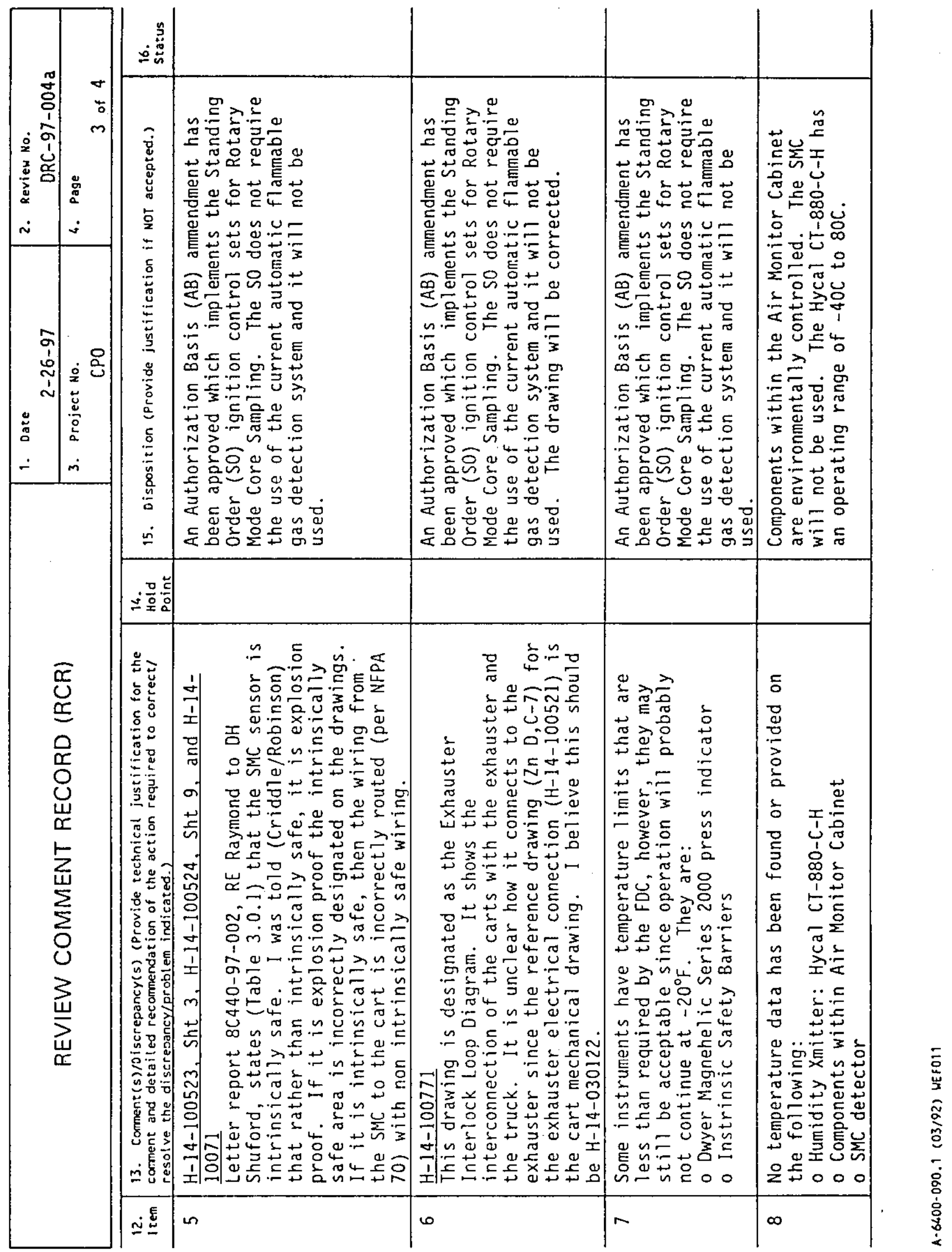




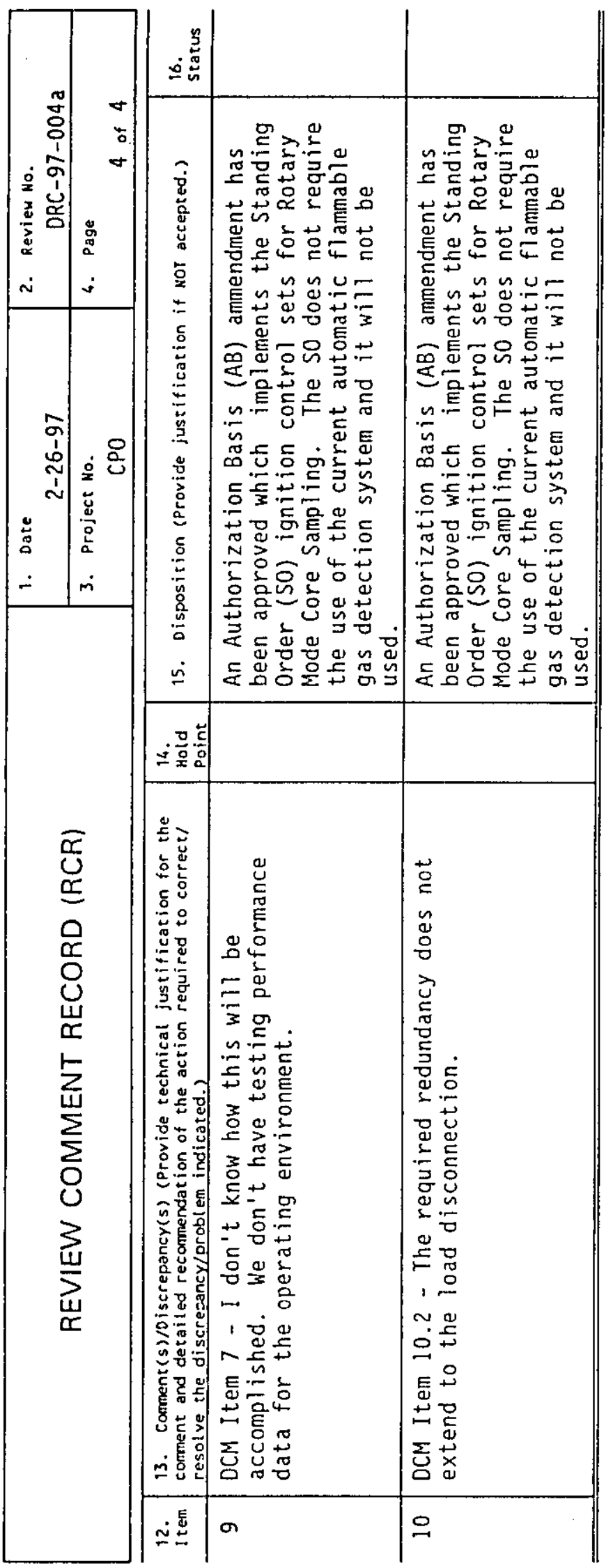


HNF-2369

Rev. 0

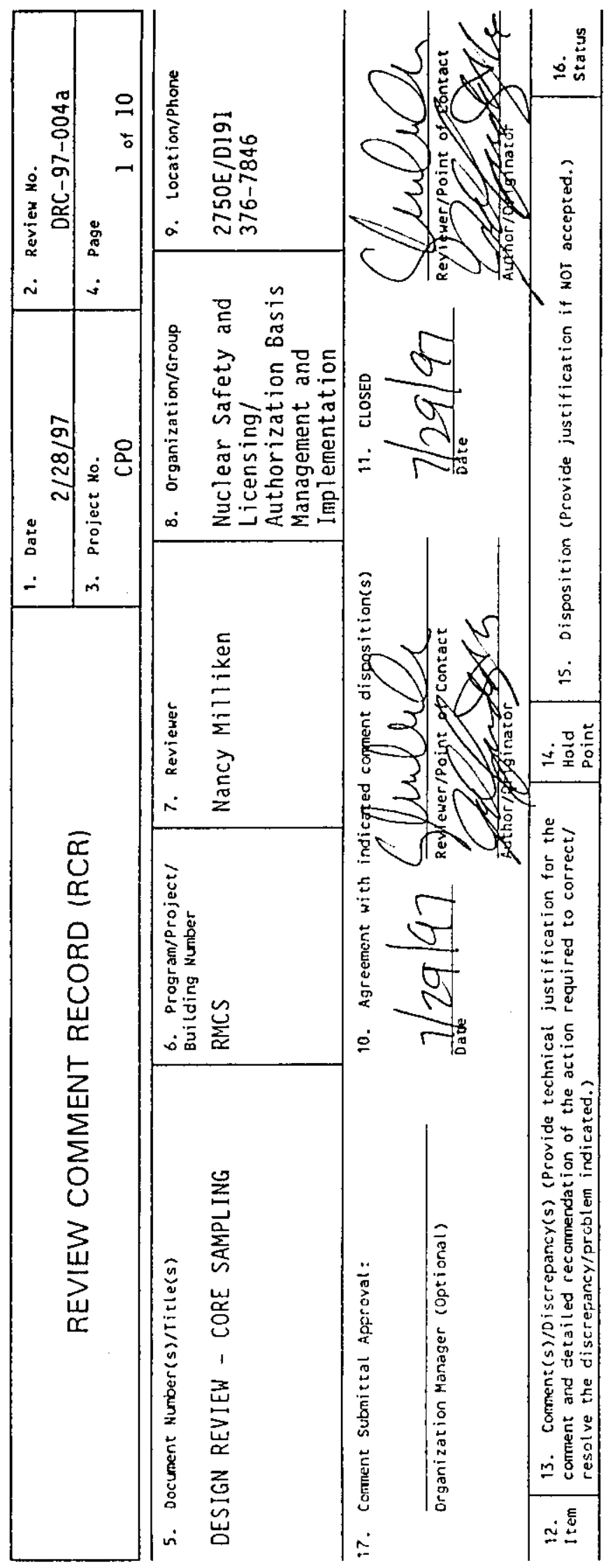

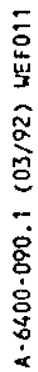

Page 5.4 - 33 
HNF-2369

Rev. 0

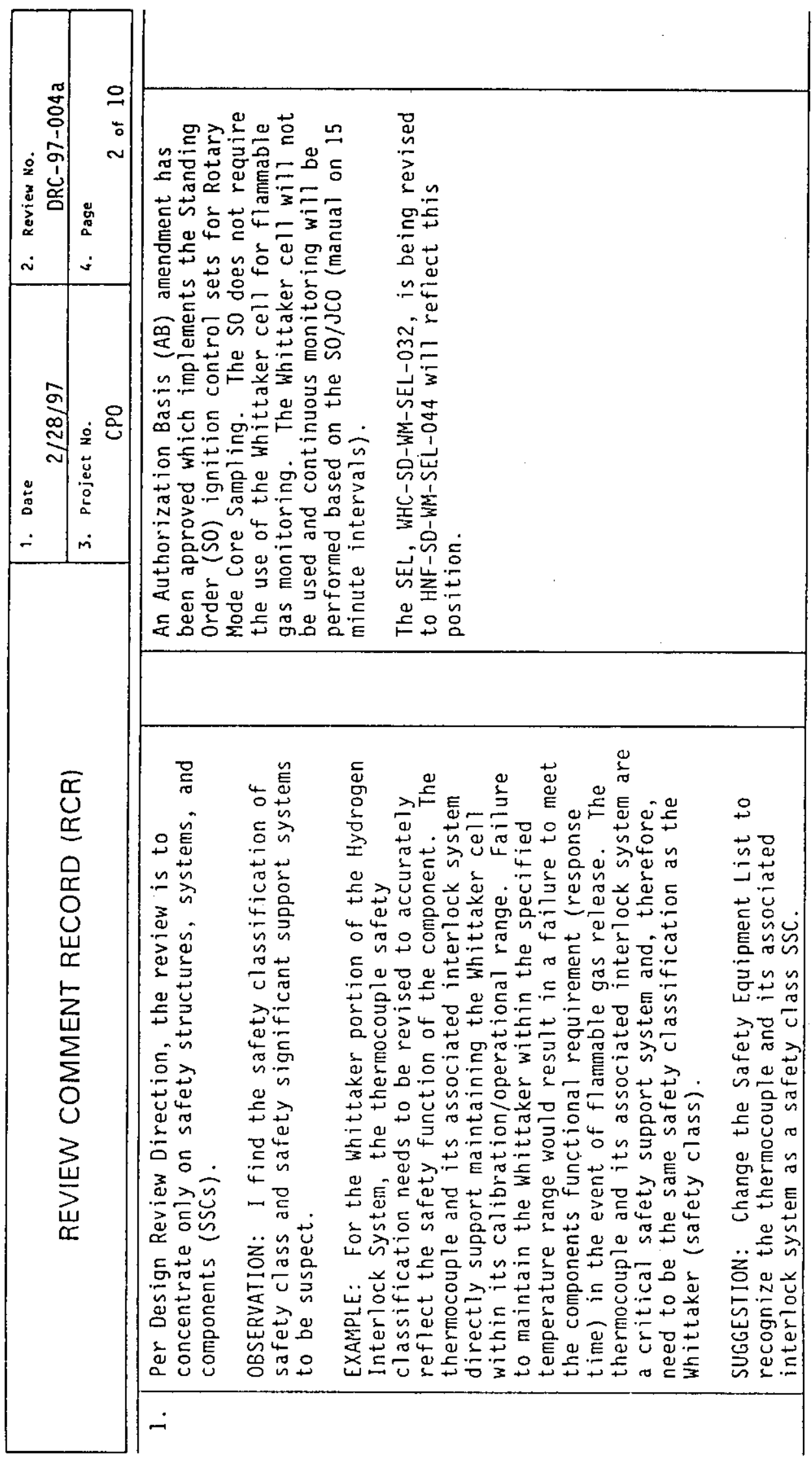


HNF-2369

Rev. 0

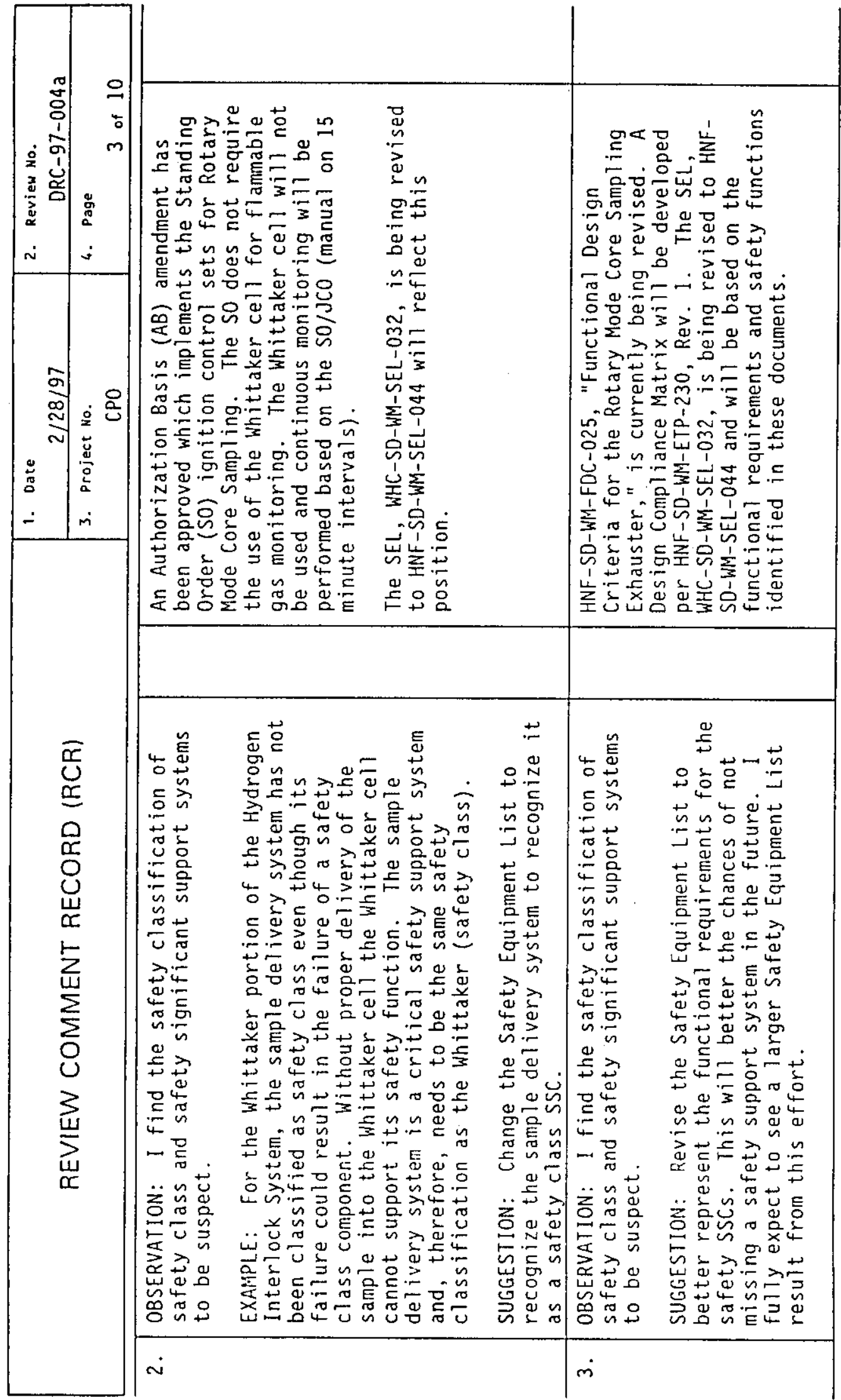


HNF-2369

Rev. 0

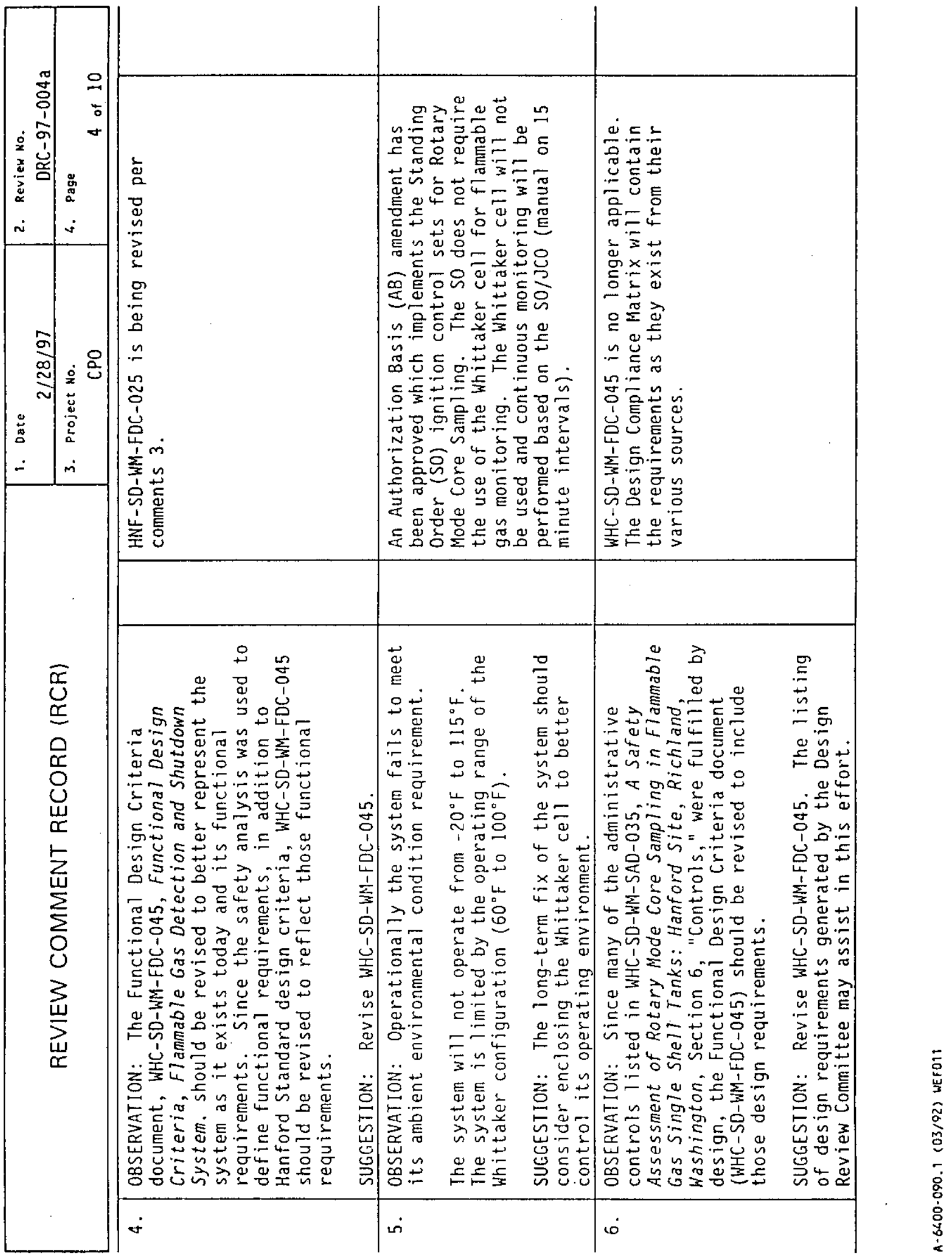

Page 5.4 - 36 


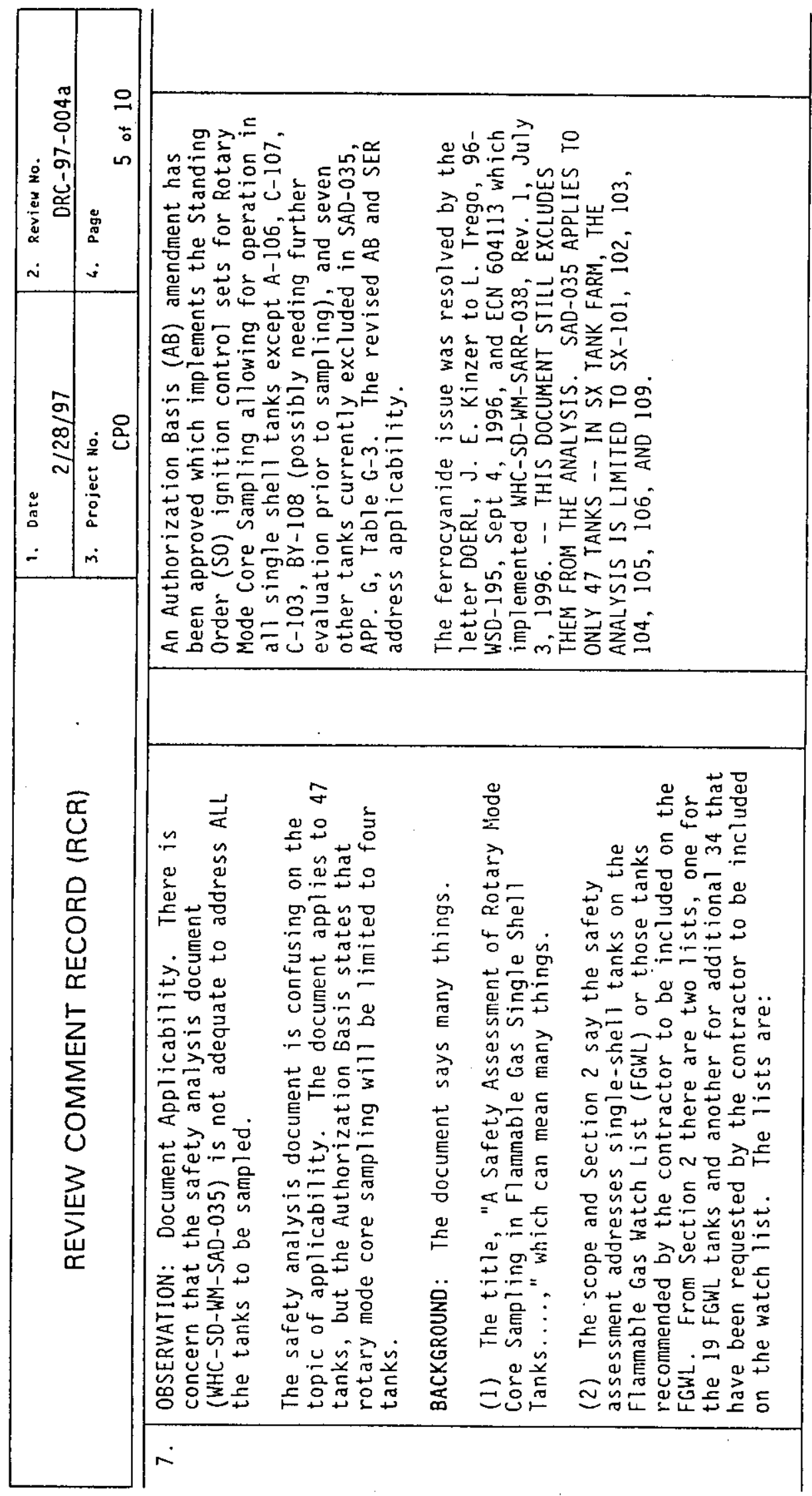




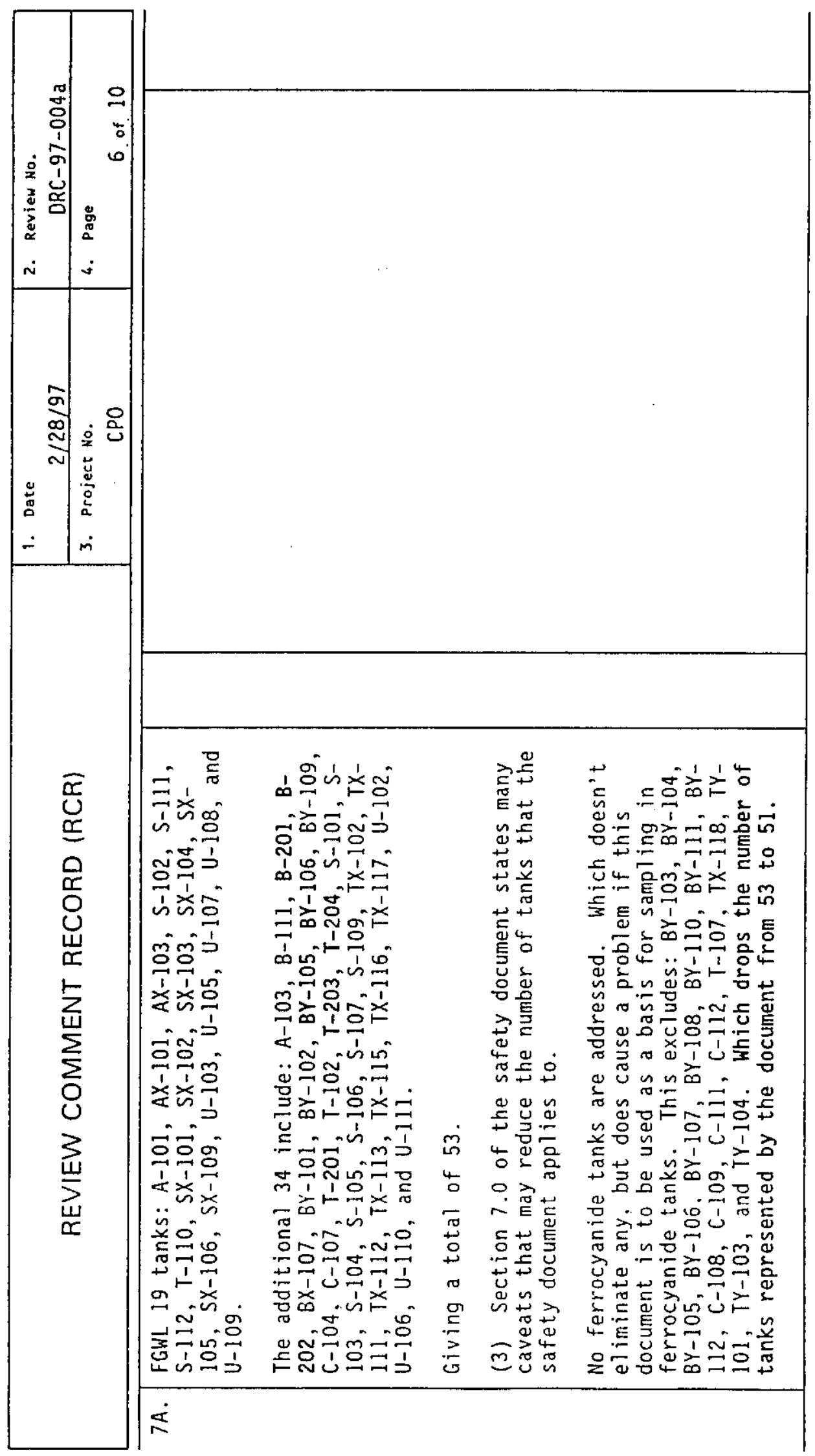




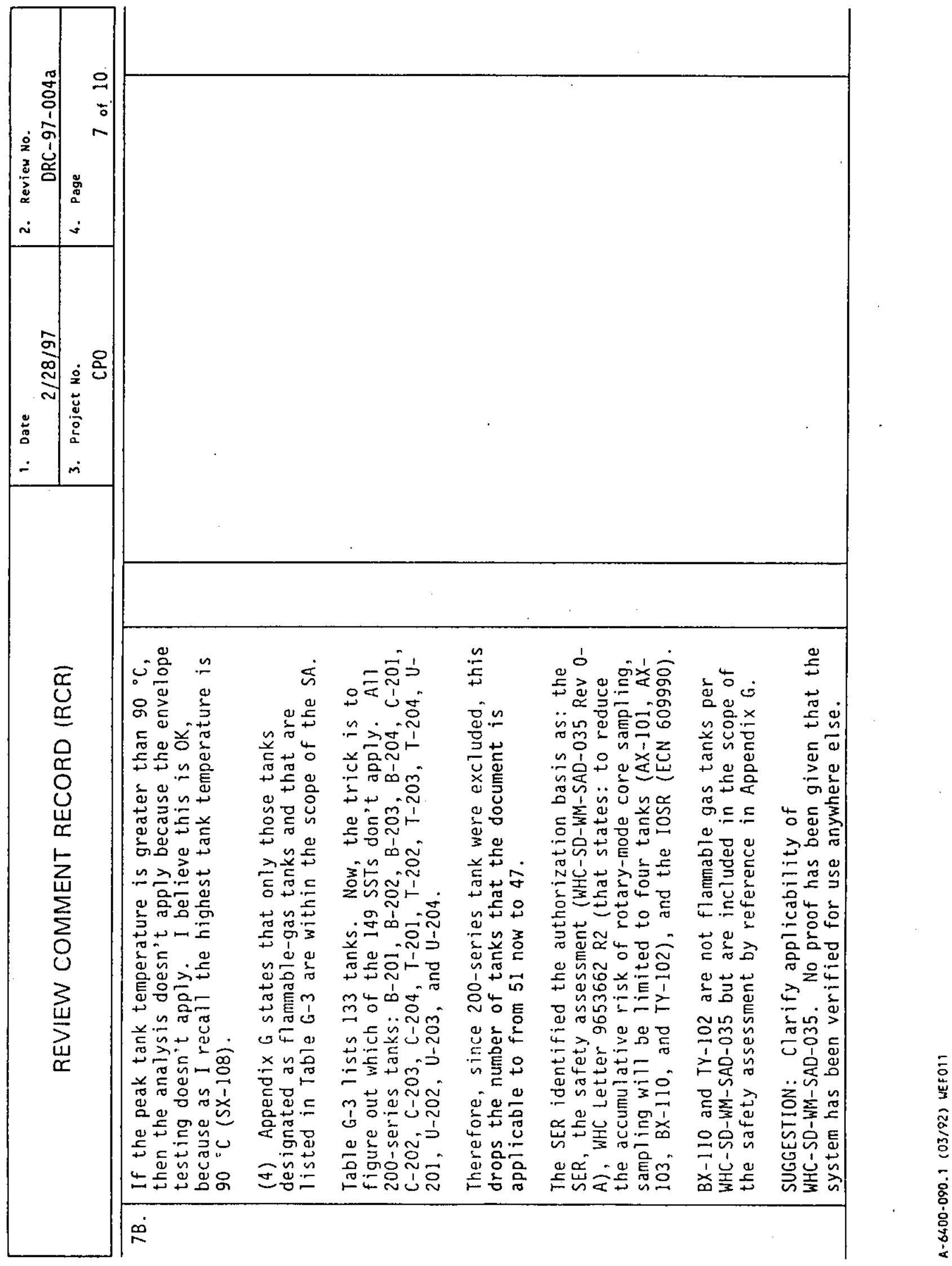

Page 5.4 - 39 


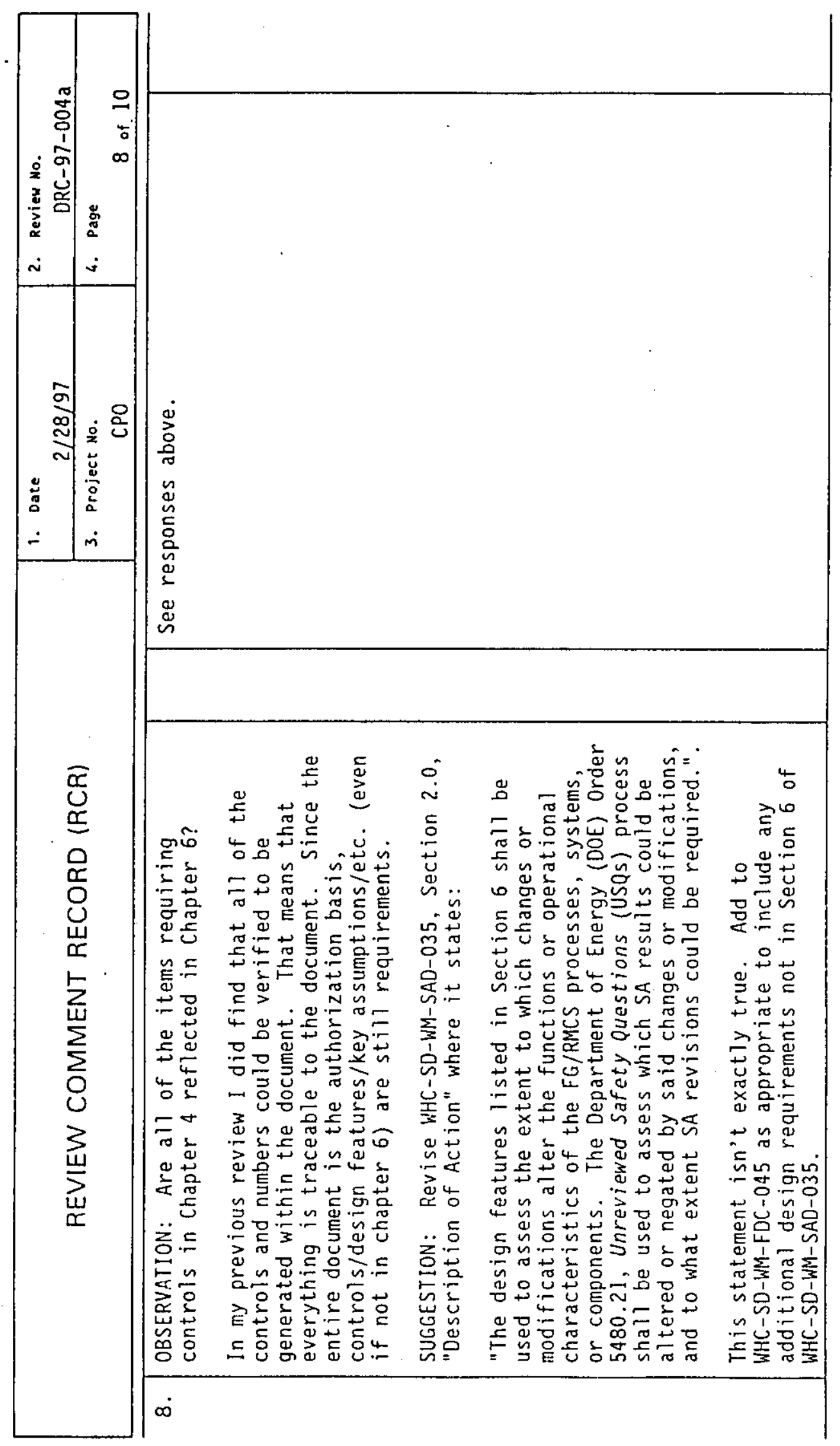


HNF-2369

Rev. 0

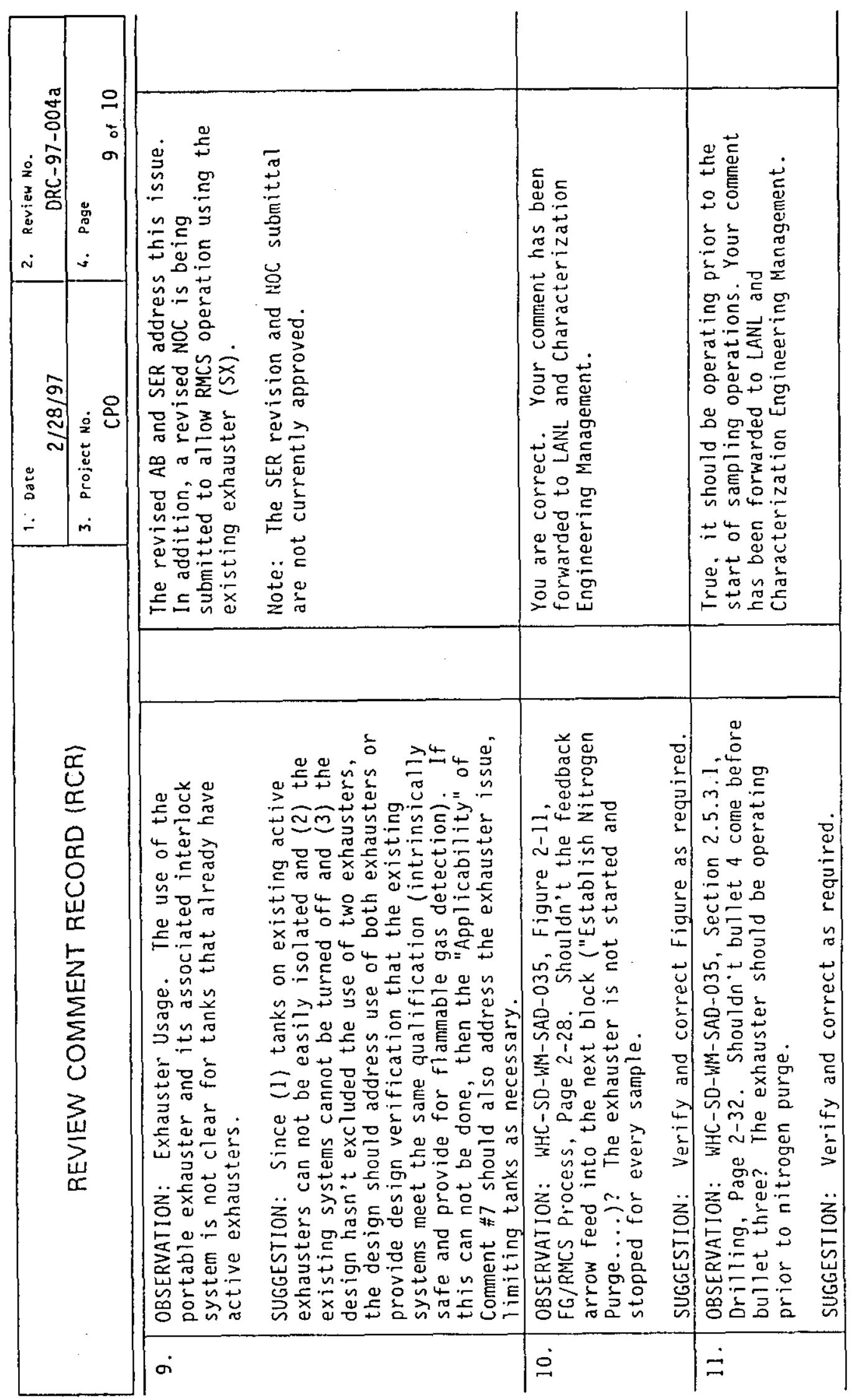

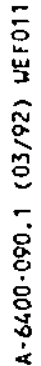


HNF-2369

Rev. 0

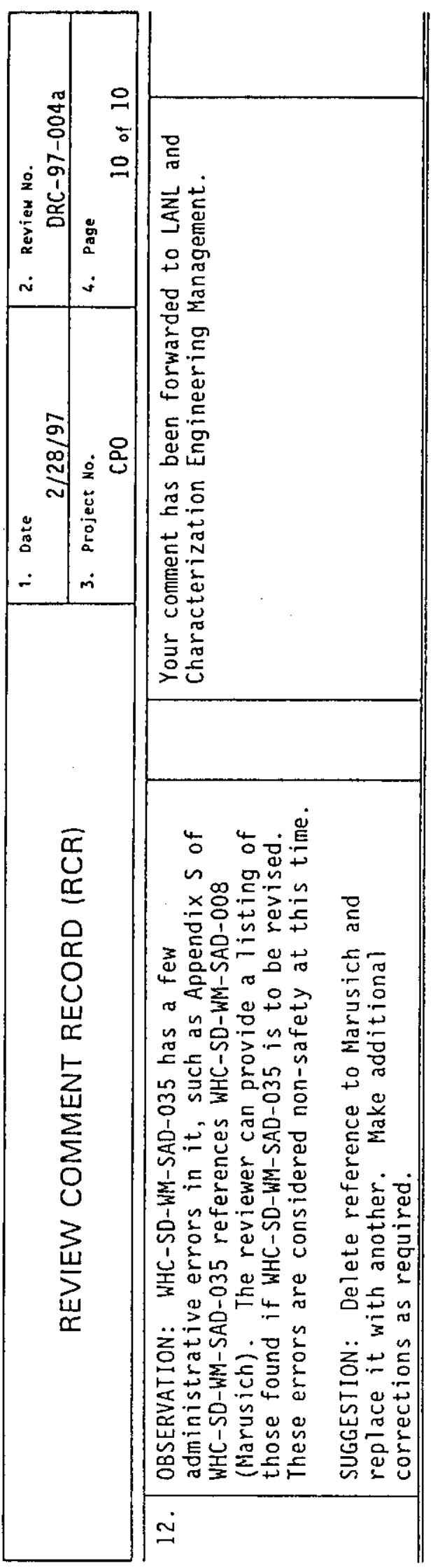




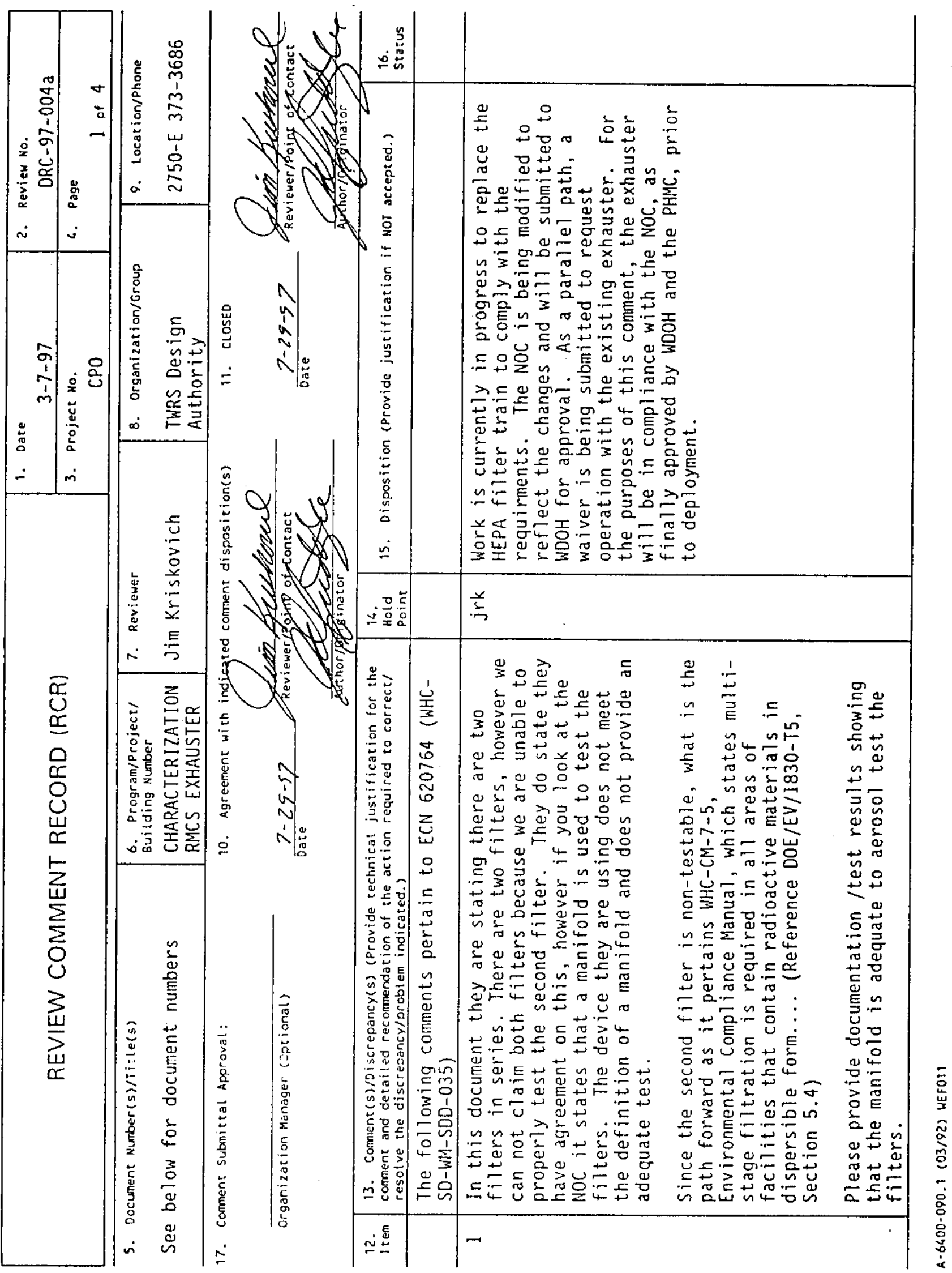




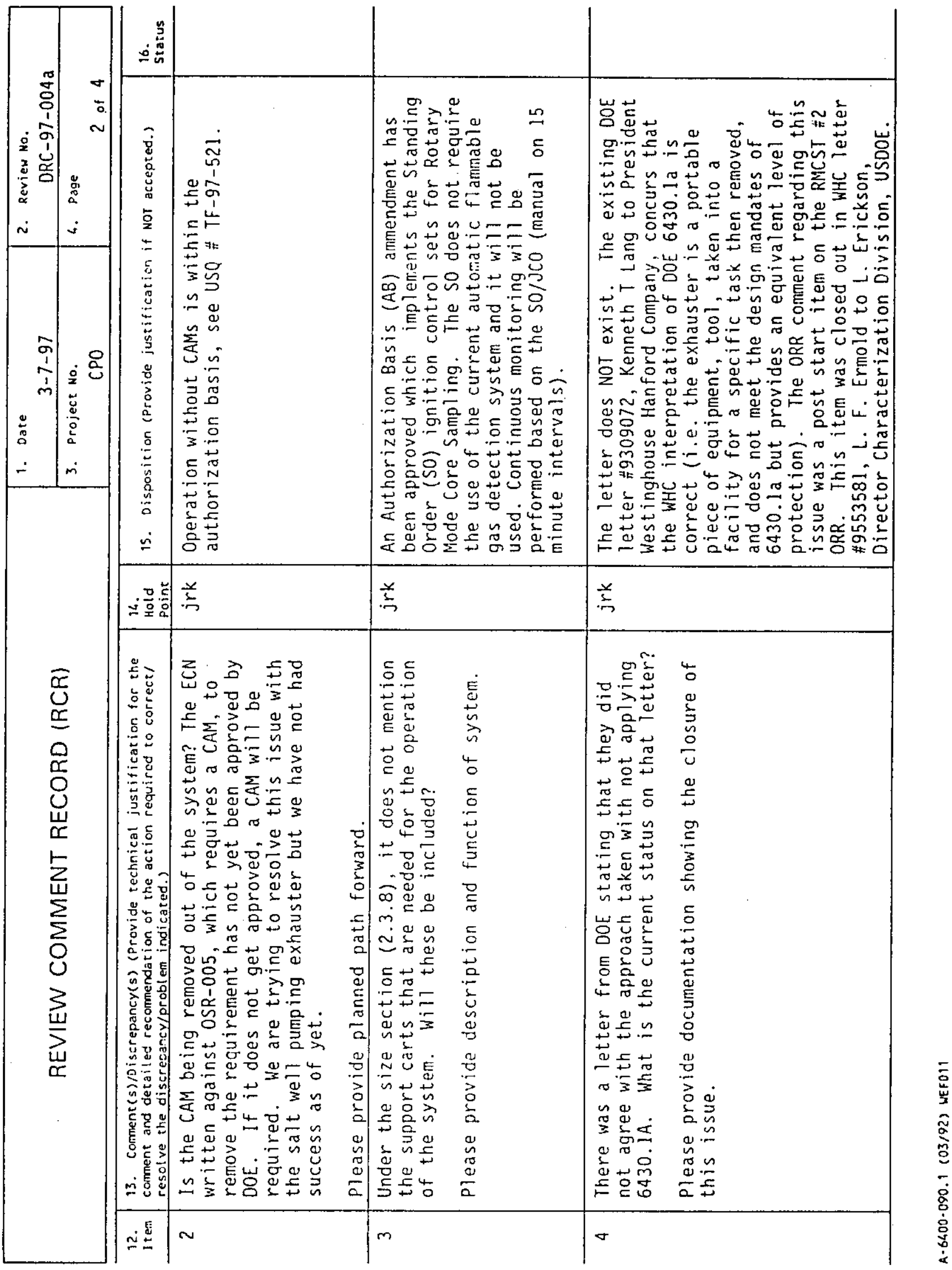


HNF-2369

Rev. 0

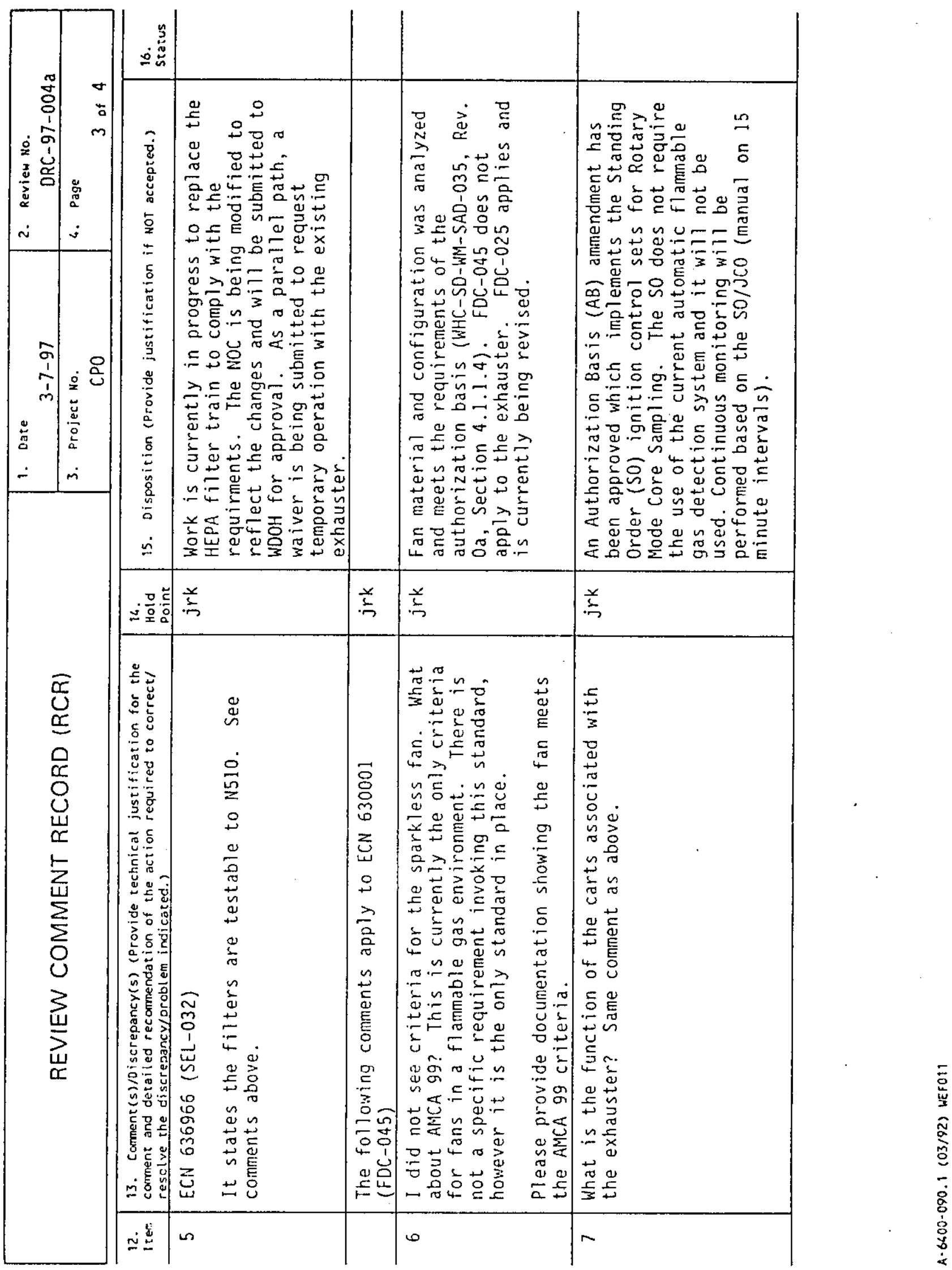

Page 5.4 - 45 
HNF-2369

Rev. 0

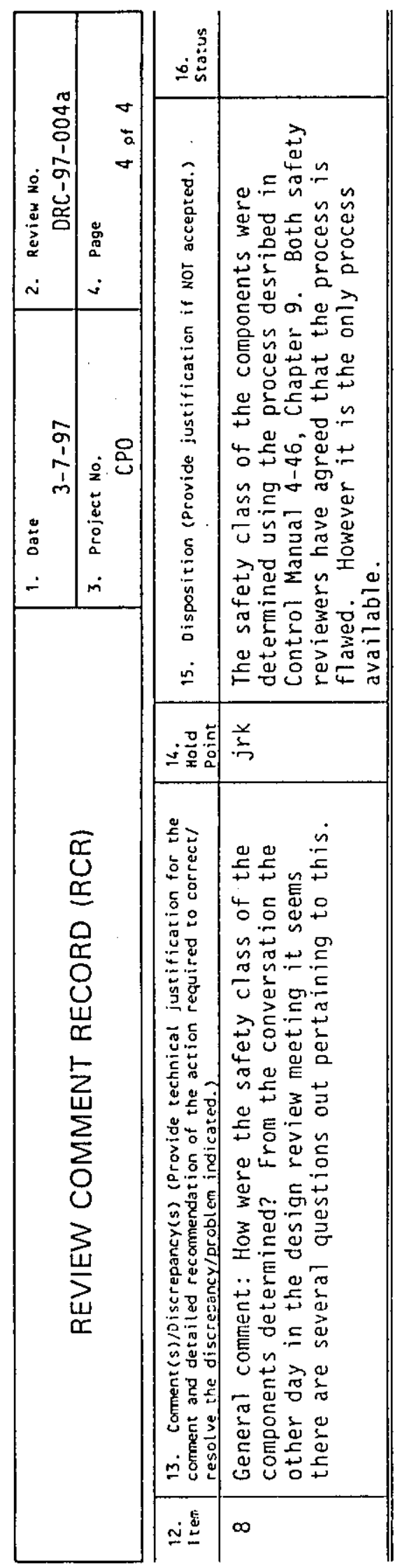


HNF-2369

Rev. 0

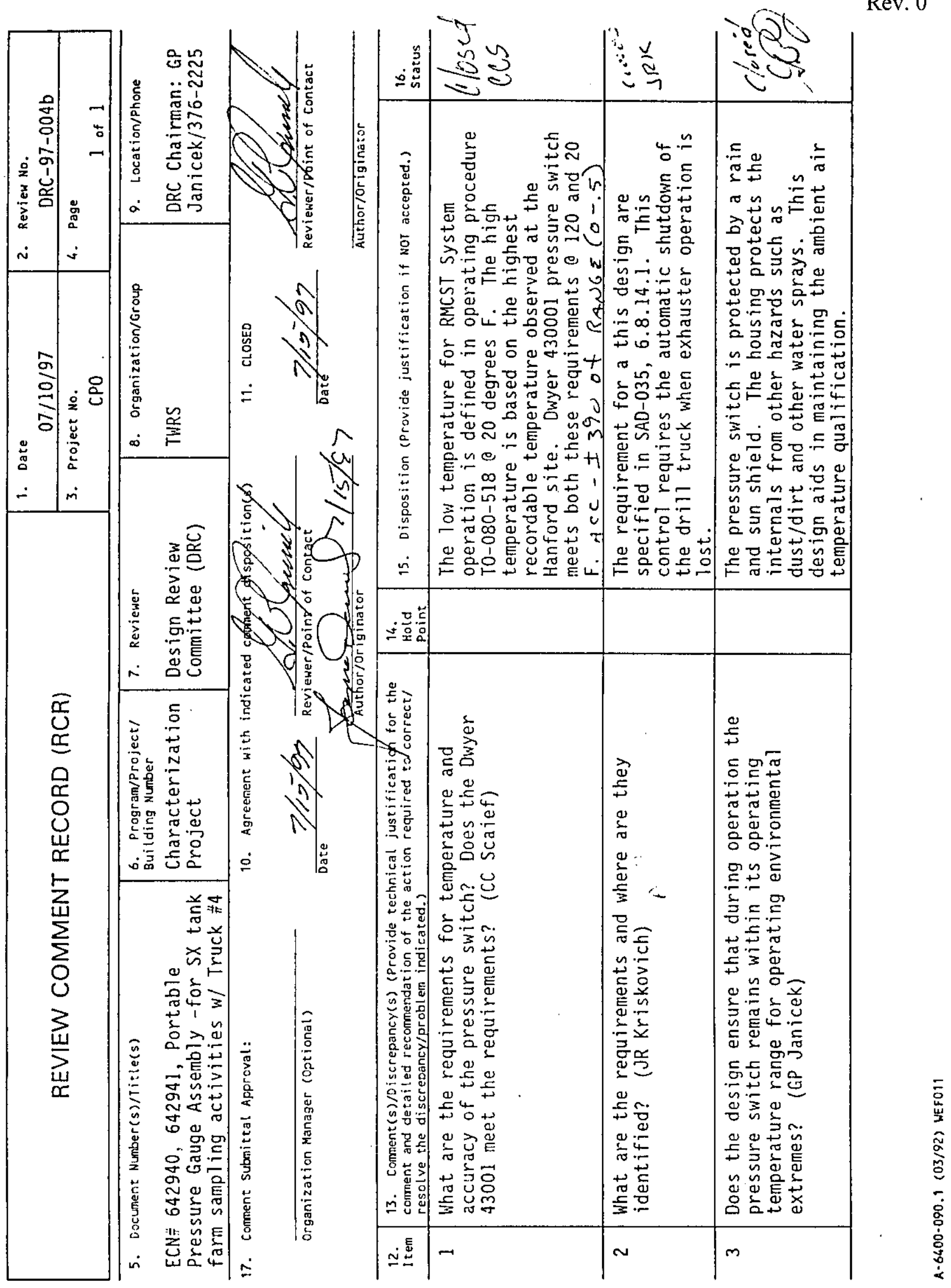




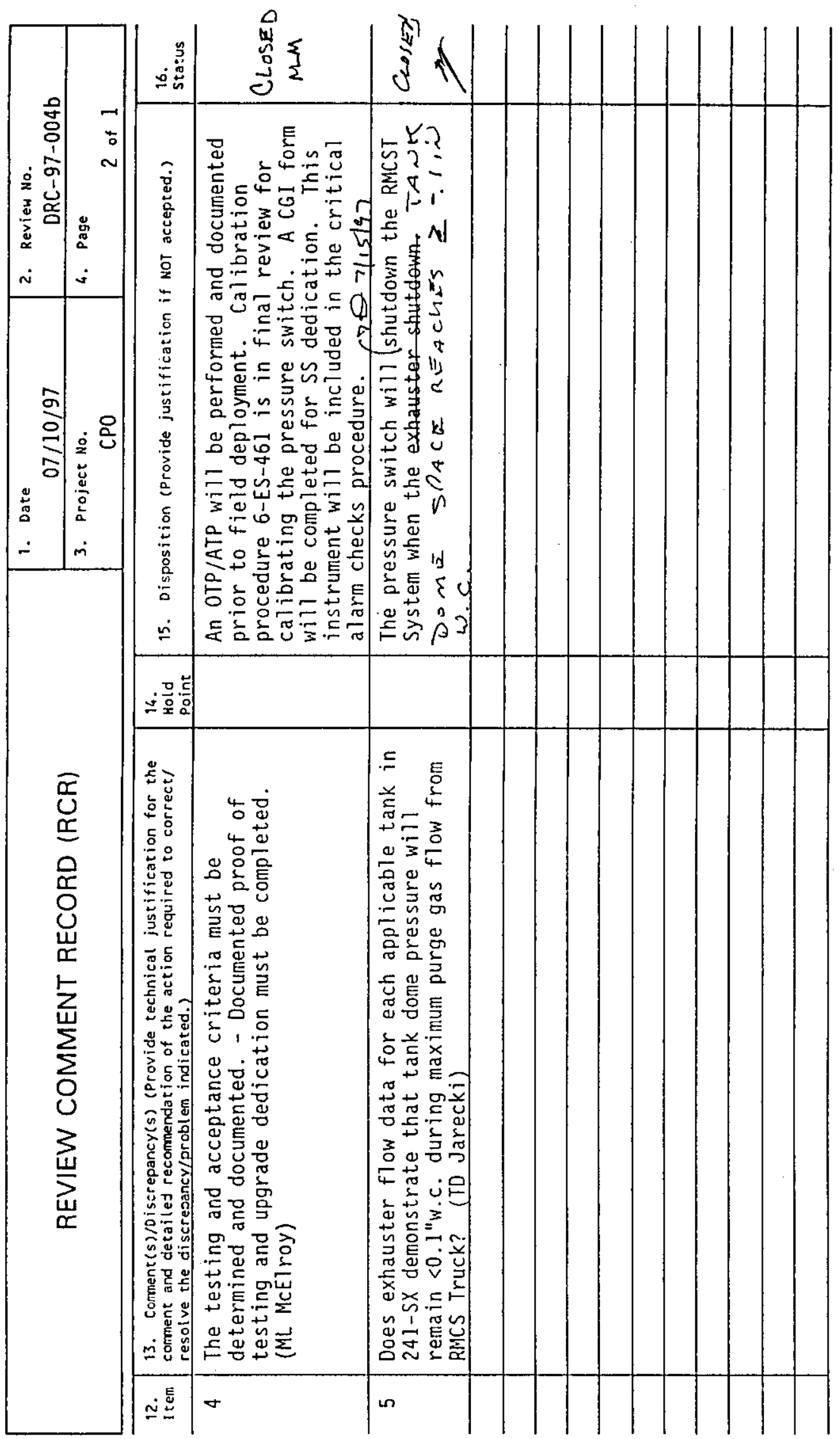

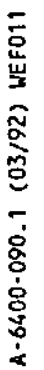




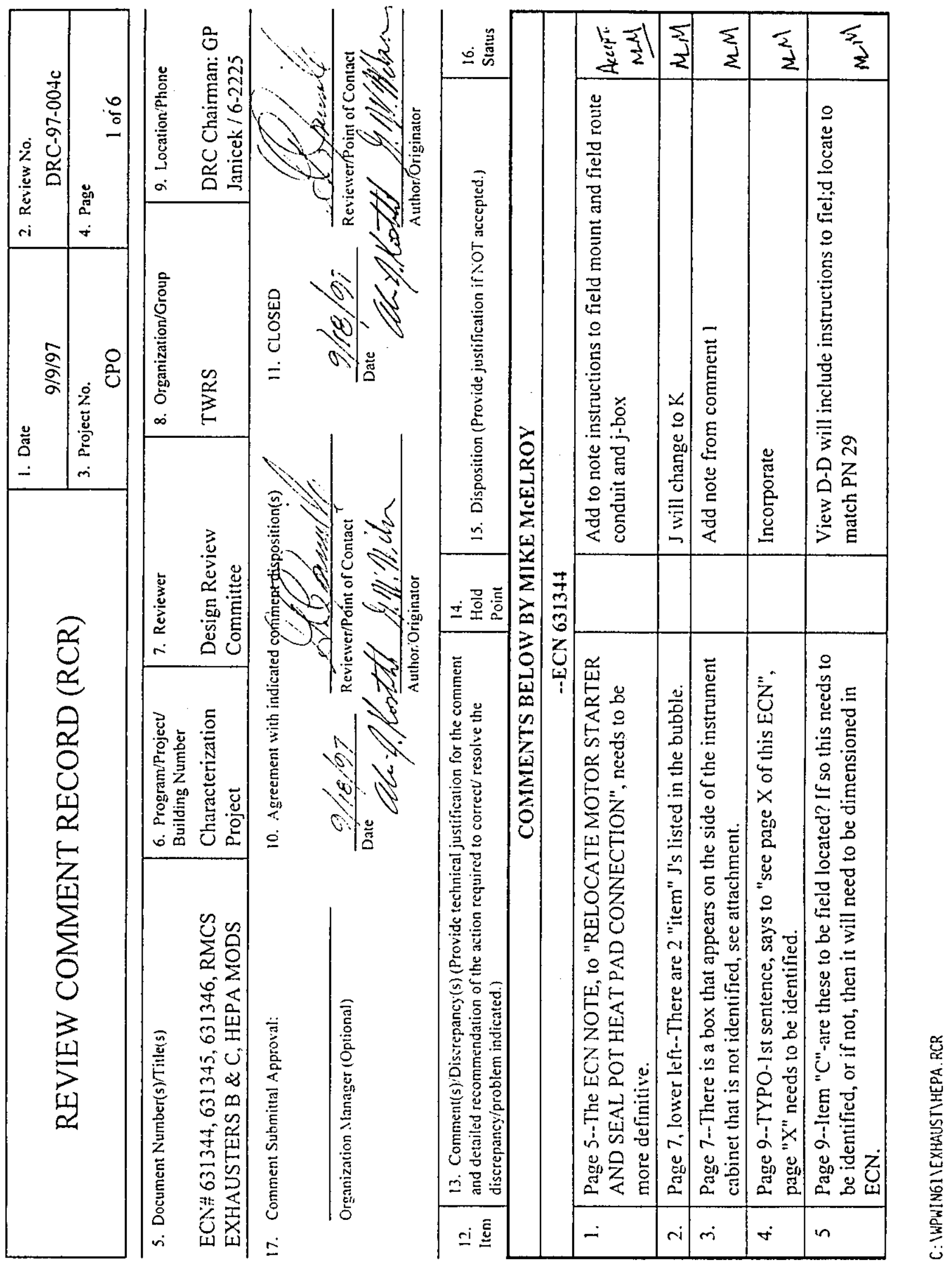




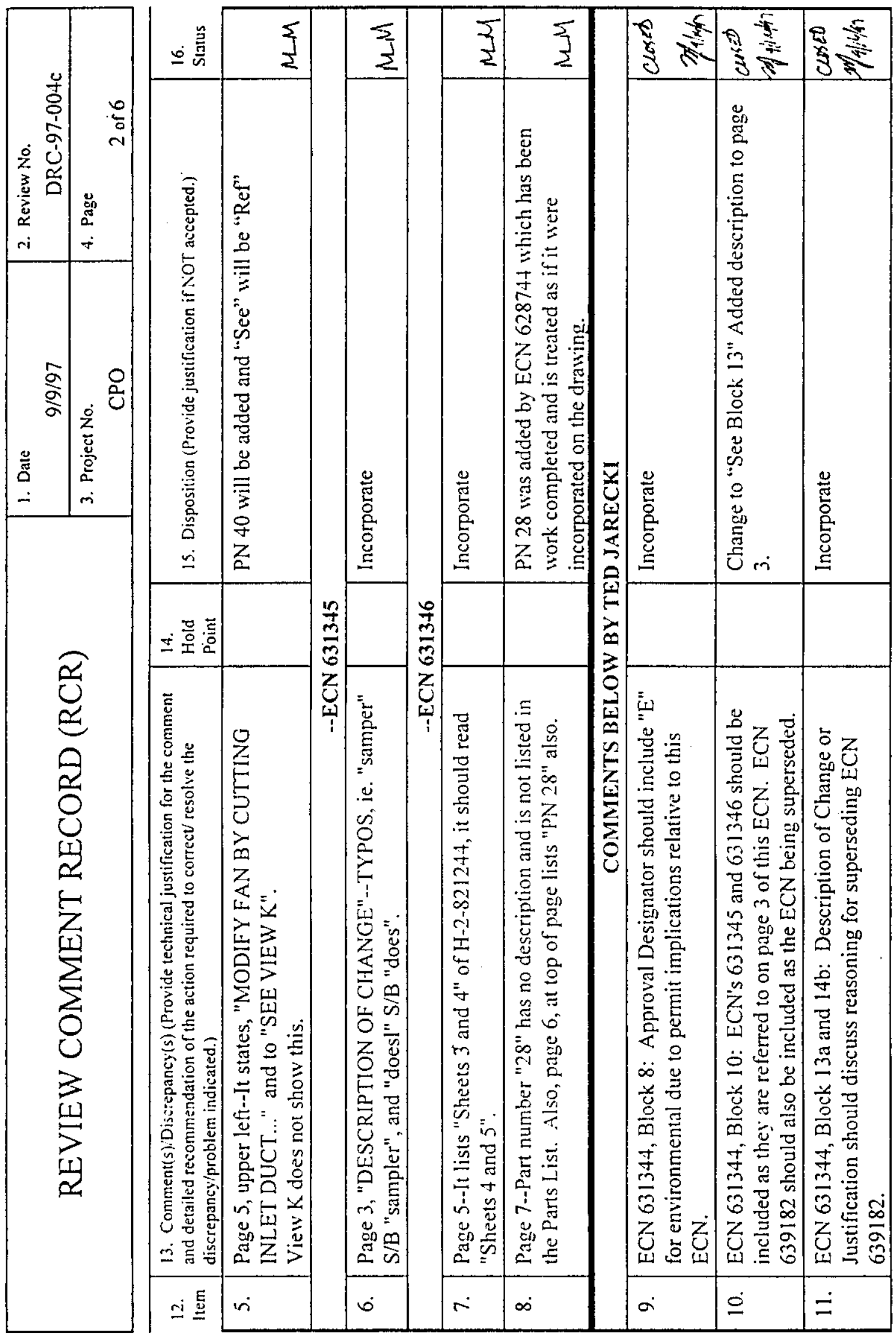

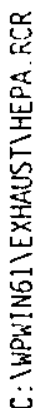


HNF-2369

Rev. 0

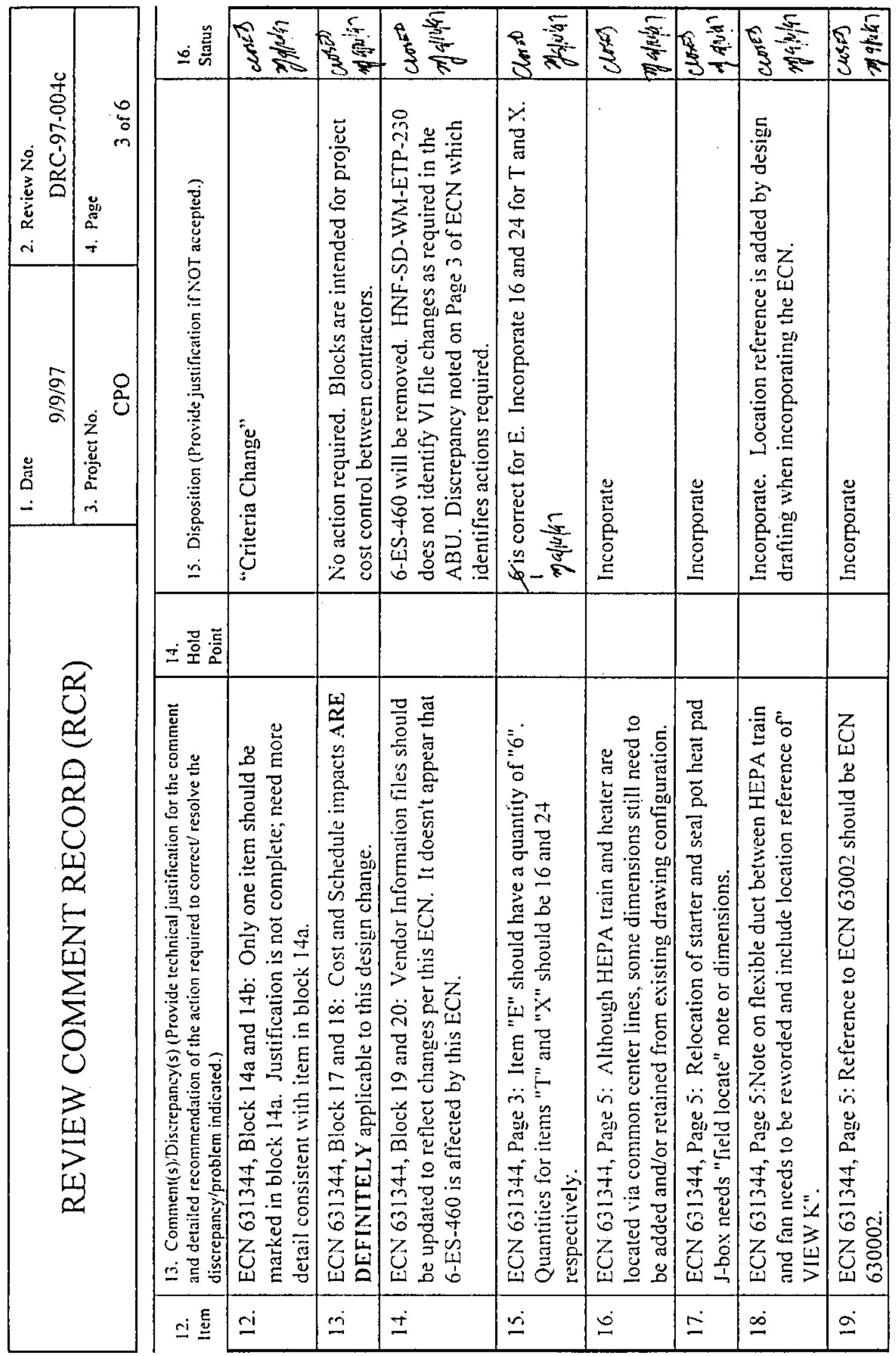

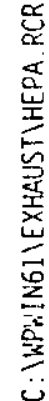




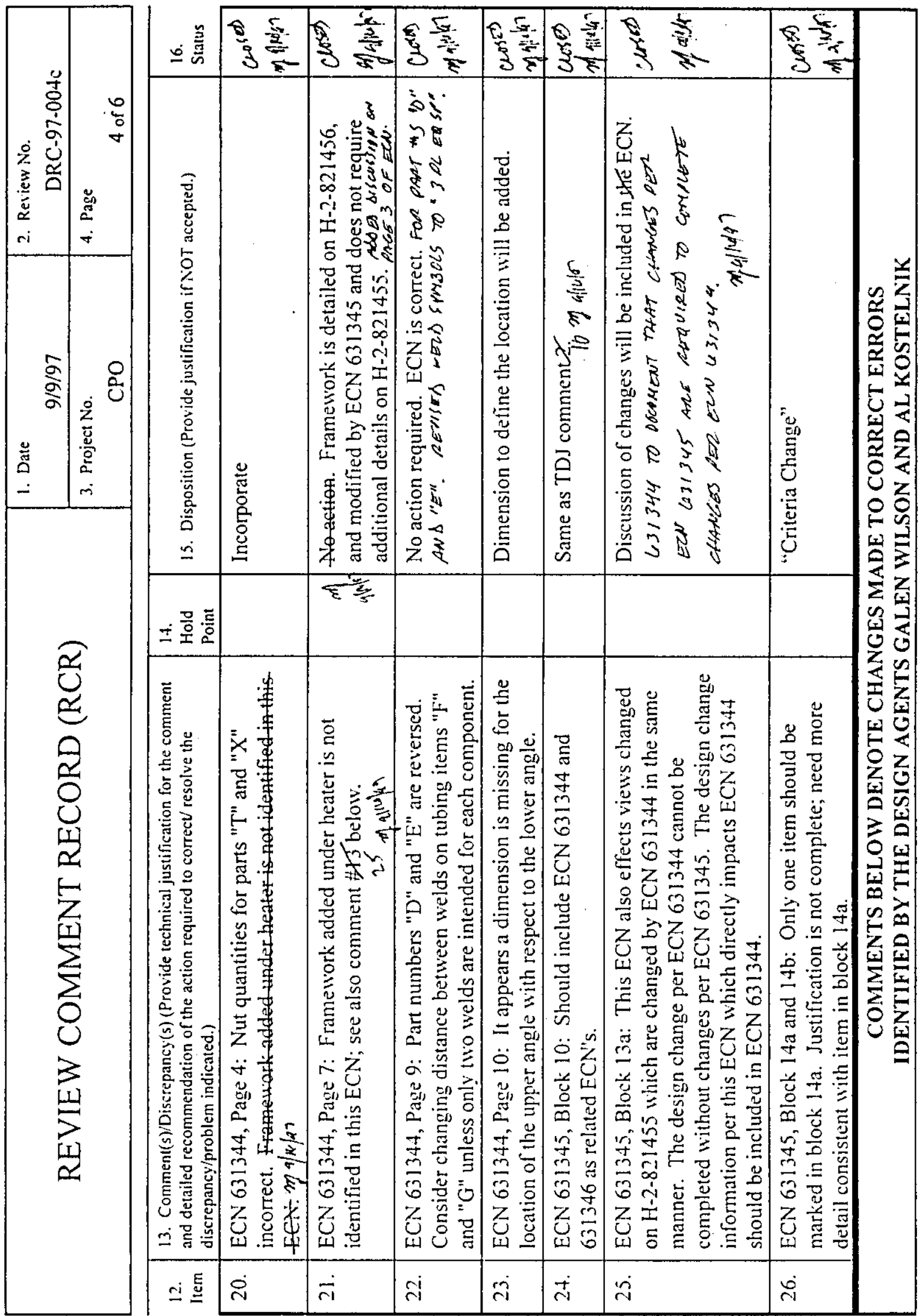




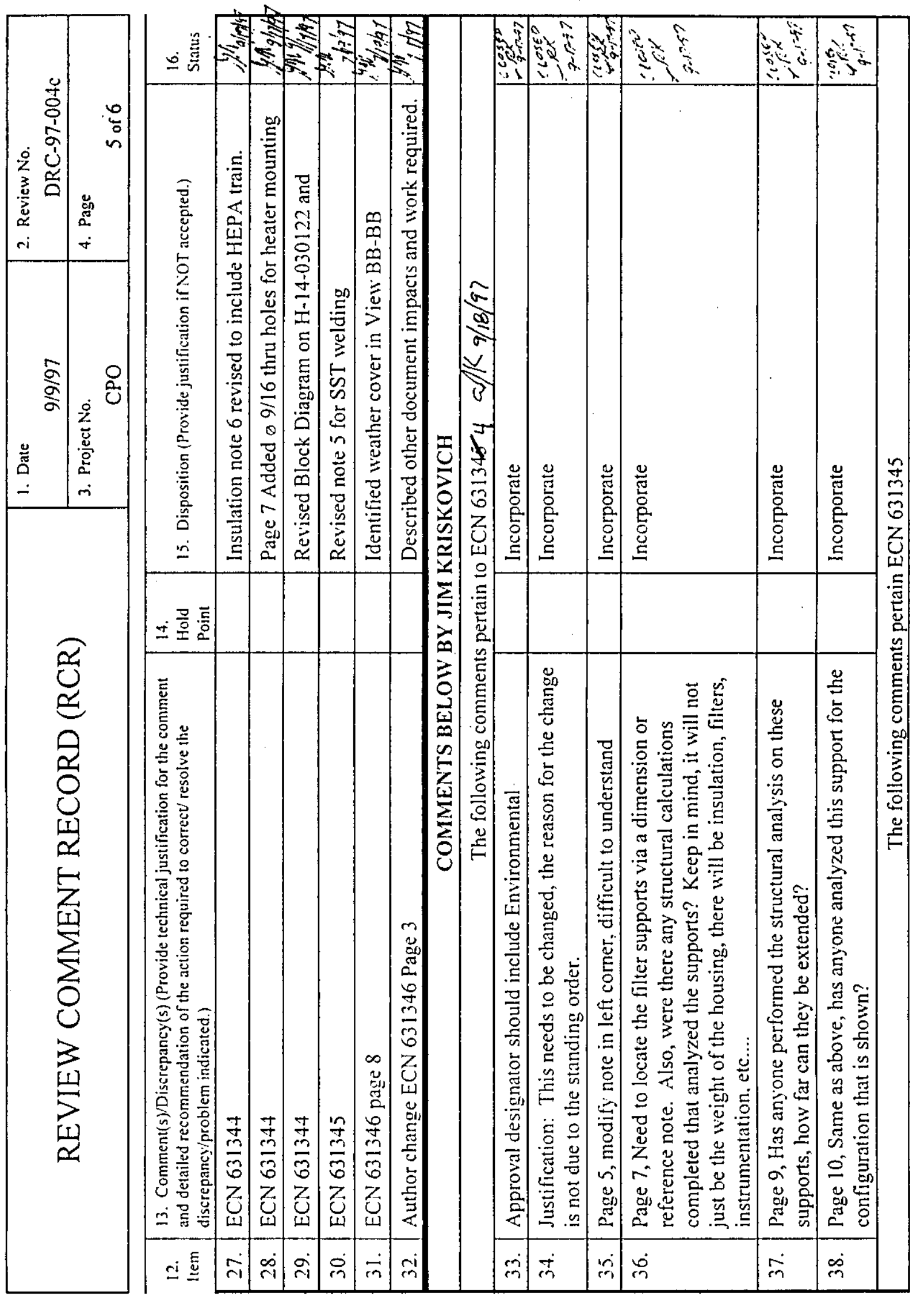

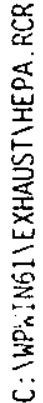


HNF-2369

Rev. 0

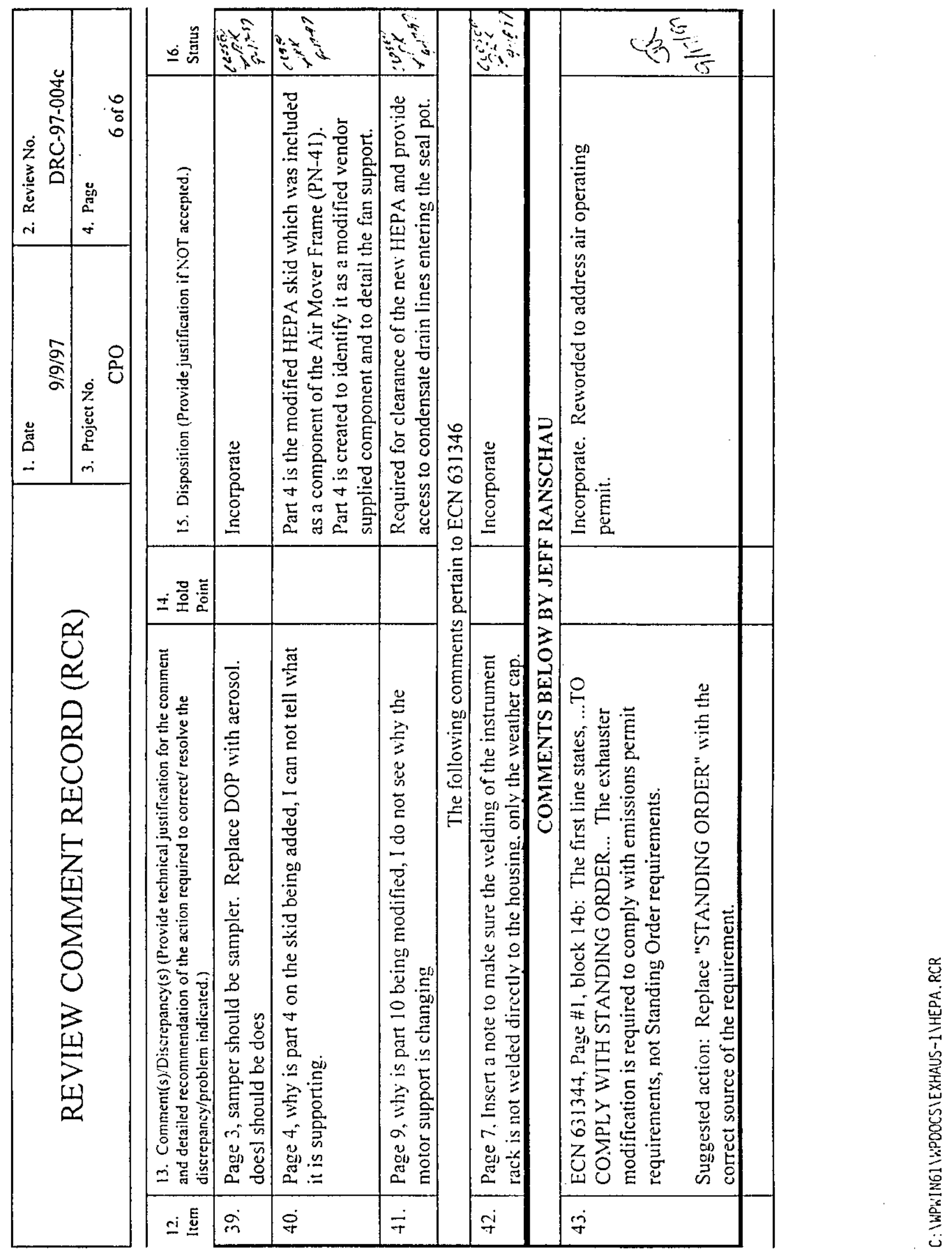

Page 5.4 - 54 


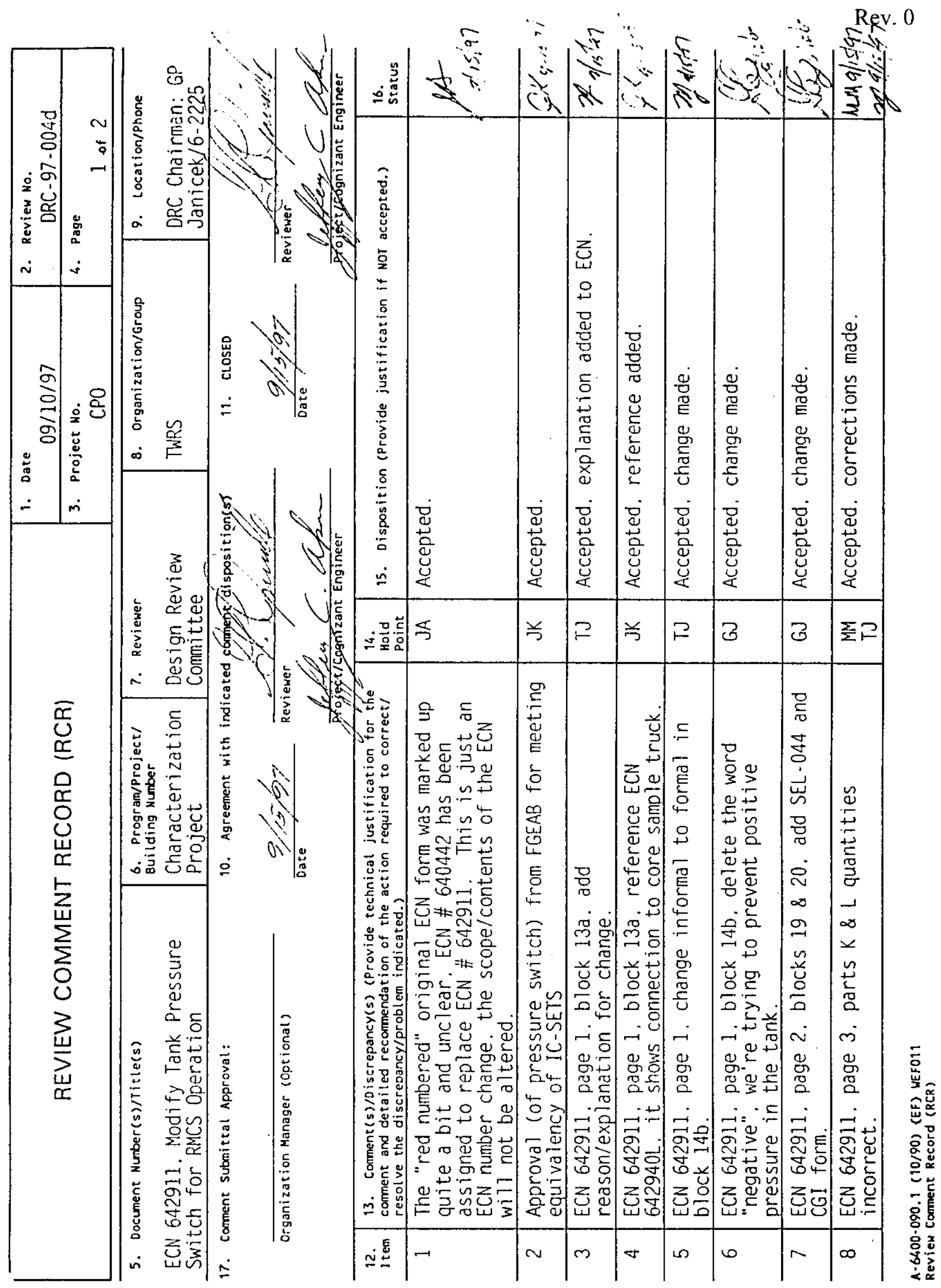

Page 5.4 - 55 


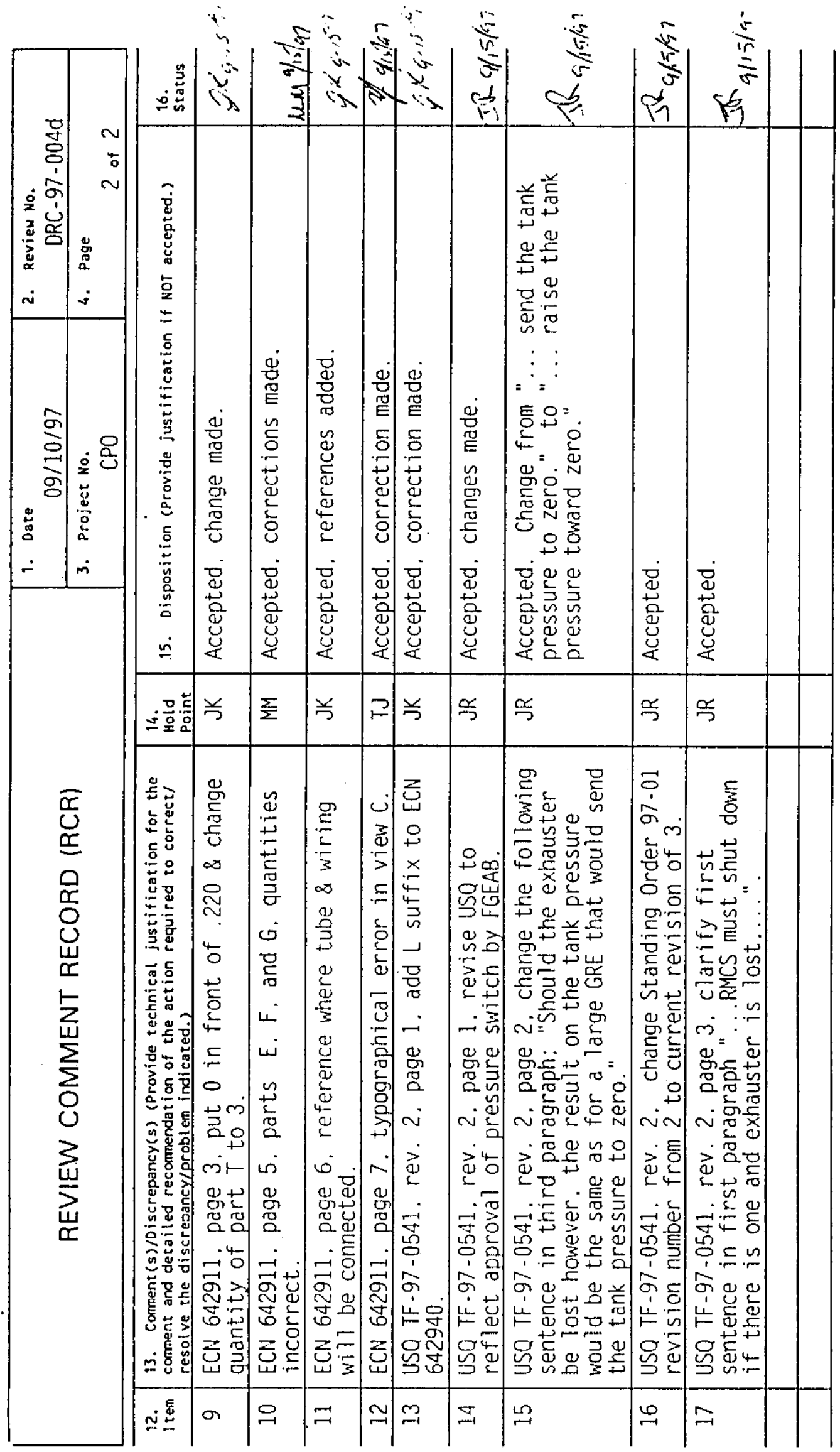




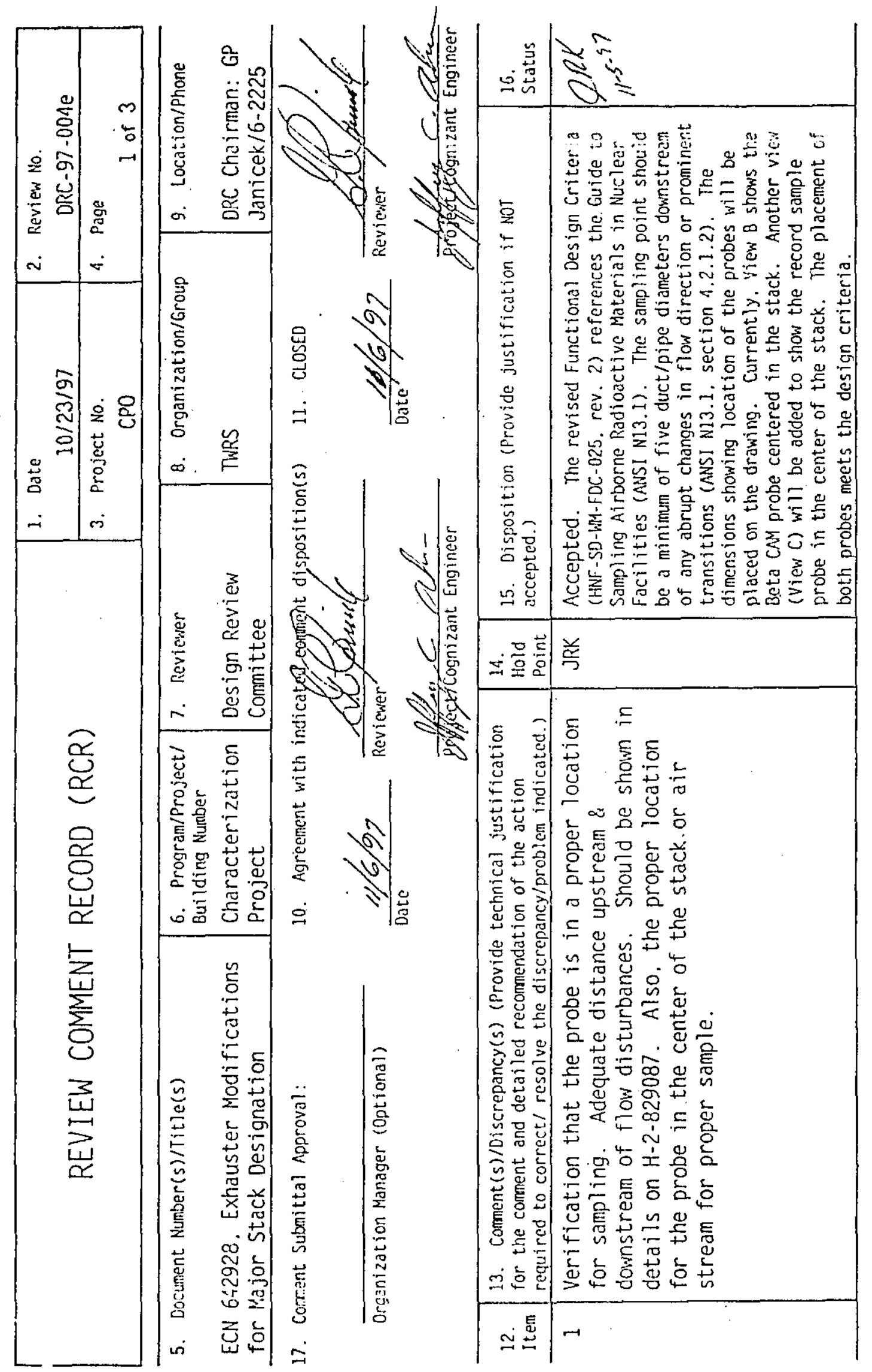

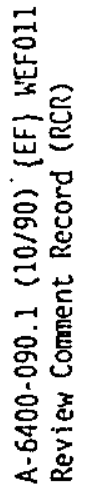


HNF-2369

Rev. 0

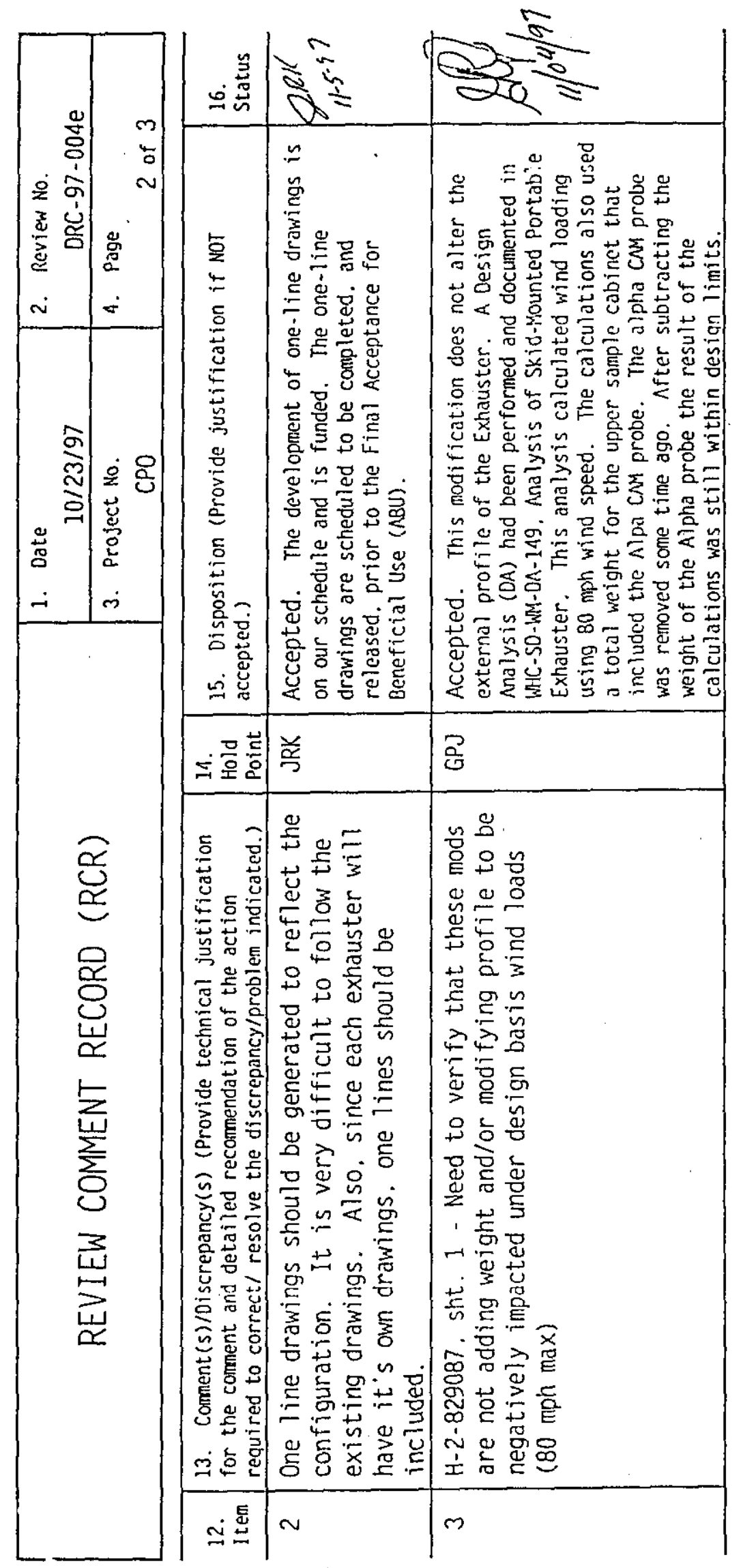

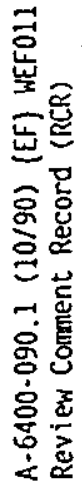

Page 5.4 - 58 


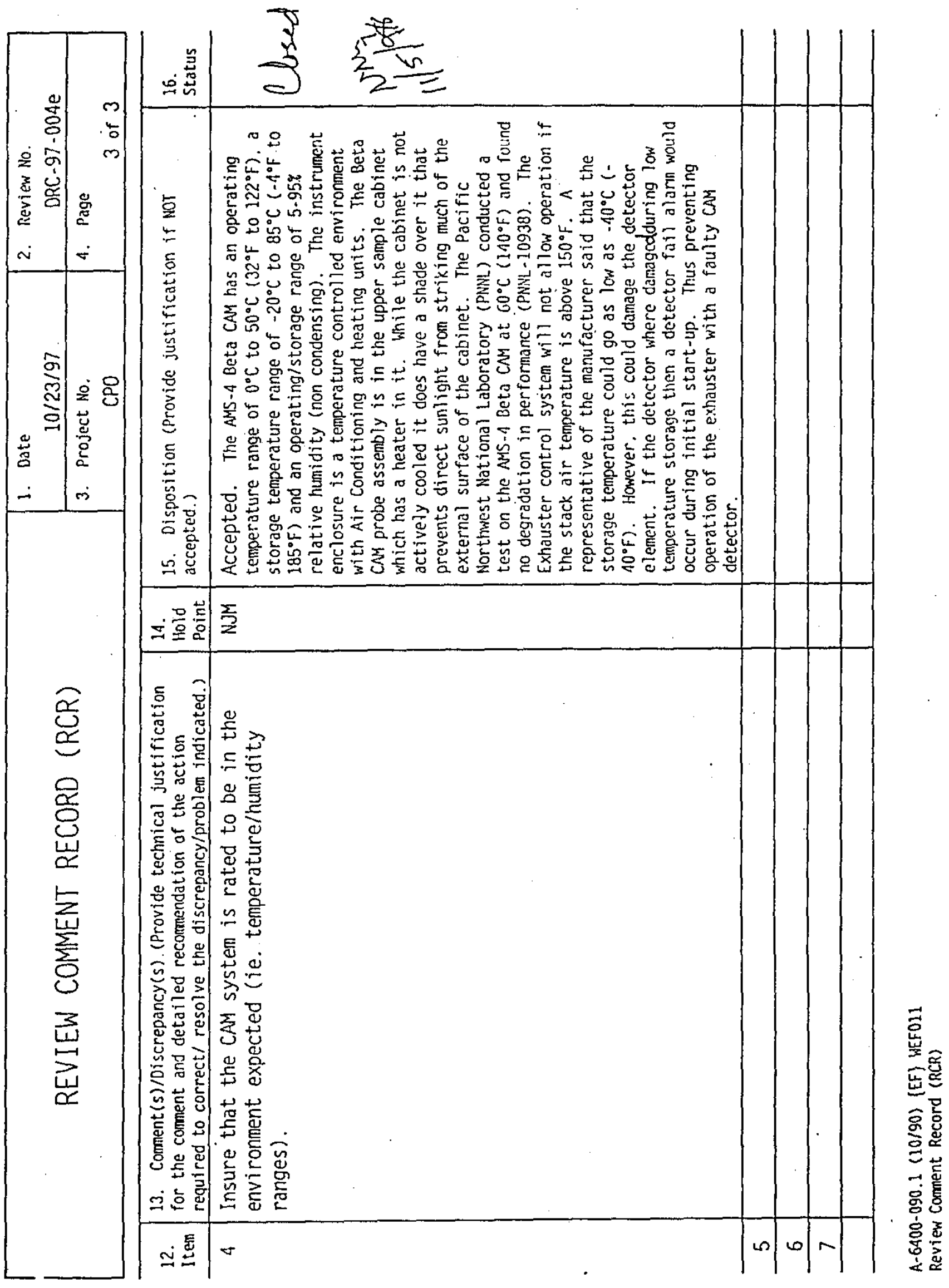

Page 5.4 - 59 
HNF-2369

Rev. 0

\subsection{DESIGN REVIEW COMMITTEE MEETING AGENDAS}

Page 5.5 - 1 
HNF-2369

Rev. 0

AGENDA

DESIGN REVIEW COMMITTEE MEETING

CHARACTERIZATION EQUIPMENT

FEBRUARY 3, 1997

MEETING MINUTES:

1. Read and approve 01/29/97 meeting minutes.

2. Actions to prior meeting minutes.

\section{CONTINUING ACTIVITIES:}

1. Review \#DRC-97-001 (ECN\# 639111, Exhauster system transmitter modification).

a. Checklist action items completed, final review, signoff.

b. Review Comment Record (RCR) dispositions complete, signoff.

c. Approve ECN.

2. Review \#DRC-97-002 (ECN\#636965, Nickel plated drill rod).
a. Review checklist.
b. Review RCR dispositions.
c. ECN approval status.

3. Review \#DRC-97-003 (ECN\# 639110, Revision to WHC-SD-WM-020, Flammable Gas Tank Exhauster Interlock (FGTEI) Computer Software Design Description).
a. Review RCR comments and disposition.
b. Review checklist.
c. ECN approval status.

\section{NEW ACTIVITIES:}

1. Briefing: Review \#DRC-97-004 (Exhauster Interlock System design).
a. Scope, schedule, personnel.
b. H-14 drawings with approved ECNs awaiting incorporation.
c. Review supporting documents.
d. Checklist review and assignments.

NEXT MEETING:

1. $02 / 05 / 97,2704 H V / G 229$.

a. $\quad 1: 00-2: 00 \mathrm{pm}$, Overview of SAD-035 (R. E. Raymond).

b. 2:00-4:00pm, DRC review continuation.

ACTION ITEM SUMMARY:

Page 5.5 - 2 
HNF-2369

Rev. 0

AGENDA

DESIGN REVIEW COMMITTEE MEETING

CHARACTERIZATION EQUIPMENT

FEBRUARY 5, 1997

MEETING MINUTES:

1. Read and approve 02/03/97 meeting minutes.

2. Actions to prior meeting minutes.

\section{CONTINUING ACTIVITIES:}

1. Review \#DRC-97-003 (ECN\# 639110, Revision to WHC-SD-WM-020, Fl ammable Gas Tank Exhauster Interlock (FGTEI) Computer Software Design Description).

a. Review RCR comments and disposition.

b. Review checklist.

c. ECN approval status.

2. Review \#DRC-97-002 (ECN\# 636965, Nickel plated drill rod).

a. Review RCR dispositions.

b. Review checklist.

c. ECN approval status.

3. Review \#DRC-97-004 (Exhauster Intertock System design).

a. Charter/Scope (design verification vs. ORR).

b. Additional review materials.

c. Review checklist and assignments.

d. Review aids (SAD-035 overview, requirements checklist).

e. RCR comments, questions, discussion:

NEW ACTIVITIES:

1. ECN Preview: Thermocouple mount on field-deployed Whittaker Cell. NEXT MEETING:

1. $02 / / 97,2704 \mathrm{HV} /$

ACTION ITEM SUMMARY: 
HNF-2369

Rev. 0

AGENDA

DESIGN REVIEW COMMITTEE MEETING

CHARACTERIZATION EQUIPMENT

FEBRUARY 10, 1997

MEETING MINUTES:

1. Read and approve $02 / 05 / 97$ meeting minutes.

2. Actions to prior meeting minutes.

\section{CONTINUING ACTIVITIES:}

1. Review \#DRC-97-003 (ECN\# 639110, Revision to WHC-SD-WM-020, Flammable Gas Tank Exhauster Interlock (FGTEI) Computer Software Design Description).

a. Review RCR comments and disposition.

b. Review checklist.

c. ECN approval status.

2. Review \#DRC-97-004 (Exhauster System design).

a. Requirements checklist.

b. Re-7ook at Design Review Checklist.

c. RCR comments, questions, discussion.

NEW ACTIVITIES:

1. ECN Preview: Thermocouple mount on field-deployed Whittaker Cell. (RR Bafus)

2. Walkthrough review of HNF-SD-WM-TC-073, "Flammable Gas Interlock Spoolpiece Flow Response Test Plan and Procedure". (TC Schneider)

NEXT MEETING:

1. $02 / 12 / 97,2704 \mathrm{HV} / \mathrm{Gl} 33,8: 30 \mathrm{am}-$ noon

\section{ACTION ITEM SUMMARY:}


HNF-2369

Rev. 0

\author{
AGENDA \\ DESIGN REVIEW COMMITTEE MEETING \\ CHARACTERIZATION EQUIPMENT \\ FEBRUARY 13, 1997
}

MEETING MINUTES:

1. Read and approve $02 / 10 / 97$ meeting minutes.

2. Actions to prior meeting minutes.

\title{
CONTINUING ACTIVITIES:
}

1. Review \#DRC-97-003 (ECN\# 639110, Revision to WHC-SD-WM-020, Fl ammable Gas Tank Exhauster Interlock (FGTEI) Computer Software Design Description).
a. Review RCR comments and disposition.
b. Review checklist.
c. ECN approval status.

2. Review \#DRC-97-005 (ECN\# 168908, Thermocouples on field deployed Whittaker Electrochemical Cell (WEC)).

a. Finalize Design Review Checklist.

3. Review \#DRC-97-004 (Exhauster fntertock System design).
a. Requirements checklist.
b. Re-look at Design Review Checklist.

NEW ACTIVITIES:

NEXT MEETING:

1. $02 / 14 / 97,2704 H V / G 229,8: 00 \mathrm{am}-4: 00 \mathrm{pm}$, Review \#DRC-97-005 (only). ACTION ITEM SUMMARY: 
HNF-2369

Rev. 0

\author{
AGENDA \\ DESIGN REVIEW COMMITTEE MEETING \\ CHARACTERIZATION EQUIPMENT \\ FEBRUARY 14, 1997
}

\title{
MEETING MINUTES:
}

1. Read and approve 02/13/97 meeting minutes.

2. Actions to prior meeting minutes.

\section{CONTINUING ACTIVITIES:}

1. Review \#DRC-97-003 (ECN\# 639110, Revision to WHC-SD-WM-020, Flammable Gas Tank Exhauster Interlock (FGTEI) Computer Software Design Description).

a. RCR comment disposition status report.

b. Spoolpiece/WEC H2 test update.

2. Review \#DRC-97-005 (ECN\#, Thermocouple mount on field deployed Whittaker Electrochemical Cell (WEC)).

a. Conduct/complete review of ECN.

3. Review \#DRC-97-004 (Exhauster System design).

a. --no activity planned--.

NEW ACTIVITIES:

NEXT MEETING:

1. TBD

ACTION ITEM SUMMARY: 
HNF-2369

Rev. 0

\author{
AGENDA \\ DESIGN REVIEW COMMITTEE MEETING \\ CHARACTERIZATION EQUIPMENT \\ FEBRUARY 18, 1997
}

MEETING MINUTES:

1. Read and approve $02 / 14 / 97$ meeting minutes.

2. Actions to prior meeting minutes.

\title{
CONTINUING ACTIVITIES:
}

1. Review \#DRC-97-003 (ECN\# 639110, Revision to WHC-SD-WM-020,

Flammable Gas Tank Exhauster Interlock (FGTEI) Computer Software Design Description).
a. New additions to ECN.
b. RCR comments and disposition.
c. Review checklist.
d. ECN approval status.

2. Review \#DRC-97-005 (ECN\# 168908, Thermocouples on field depioyed Whittaker Electrochemical Cell (WEC)).
a. Status of $E C N$.
b. Post review discussion.

3. Review \#DRC-97-004 (Exhauster fatertokstem design).
a. SDD distribution.
b. Requirements checklist.
c. Re-look at Design Review Checklist.

NEW ACTIVITIES:

a. ECN to modify WEC piping arrangement.

NEXT MEETING:

1. $02 / 20 / 97,2704 \mathrm{HV} / \mathrm{G}, 1: 00 \mathrm{pm}-4: 00 \mathrm{pm}$

ACTION ITEM SUMMARY:

Page $5.5-7$ 
HNF-2369

Rev. 0

\section{AGENDA \\ DESIGN REVIEW COMMITTEE MEETING \\ CHARACTERIZATION EQUIPMENT}

FEBRUARY 19, 1997

\section{MEETING MINUTES:}

1. Read and approve $02 / 14 / 97$ meeting minutes.

2. Read and approve $02 / 18 / 97$ meeting minutes.

3. Actions to prior meeting minutes.

\section{CONTINUING ACTIVITIES:}

1. Review \#DRC-97-003 (ECN\# 639110, Revision to WHC-SD-WM-020, Flammable Gas Tank Exhauster Interlock (FGTEI) Computer Software Design Description).

a. Continuation of $02 / 18 / 97$ discussion on acceptability of 1 ow

temperature setpoint for WEC in the software. Resolution.

b. RCR comments and disposition.

c. Review checklist.

d. ECN approval status.

2. Review \#DRC-97-004 (Exhauster System design).
a. SDD distribution. (completed 02/18/97)
b. Updated Admin. Control (AC) design requirements.
c. Requirements checklist. (partially completed 02/18/97)
d. Re-look at Design Review Checklist.
e. Next meeting - Scope.

NEW ACTIVITIES:

a. ECN to modify WEC piping arrangement.

NEXT MEETING:

1. $02 / 20 / 97,2704 \mathrm{HV} / \mathrm{G} 230,1: 00 \mathrm{pm}-4: 00 \mathrm{pm}$

ACTION ITEM SUMMARY:

Page $5.5-8$ 
HNF-2369

Rev. 0

AGENDA

\section{DESIGN REVIEW COMMITTEE MEETING}

CHARACTERIZATION EQUIPMENT

FEBRUARY 20, 1997

\section{MEETING MINUTES:}

1. Read and approve 02/14/97 meeting minutes.

2. Read and approve $02 / 18 / 97$ meeting minutes.

3. Read and approve $02 / 19 / 97$ meeting minutes .

4. Actions to prior meeting minutes.

\section{CONTINUING ACTIVITIES:}

1. Review \#DRC-97-003 (ECN\# 639110, Revision to WHC-SD-WM-020, Flammable Gas Tank Exhauster Interlock (FGTEI) Computer Software Design Description).
a. ECN approval.

2. Review \#DRC-97-004 (Exhauster \& Interlock System design).
a. Complete Requirements Checklist (to become Design Compliance Matrix (DCM)).
b. Re-look at Design Review Checklist.
c. RCR comment due date.
d. RCR comment resolution meeting.

NEW ACTIVITIES:

1. ---NONE---

NEXT MEETING:

1. $02 / 28 / 97,2704 \mathrm{HV} / \mathrm{G} ? ? ?, 8: 00 \mathrm{am}-4: 00 \mathrm{pm}$.

ACTION ITEM SUMMARY: 
HNF-2369

Rev. 0

\section{AGENDA \\ DESIGN REVIEW COMMITTEE MEETING \\ CHARACTERIZATION EQUIPMENT \\ FEBRUARY 28, 1997}

MEETING MINUTES:

1. Read and approve $02 / 18 / 97$ meeting minutes.

2. Read and approve $02 / 19 / 97$ meeting minutes.

3. Actions to prior meeting minutes.

\section{CONTINUING ACTIVITIES:}

1. Review \#DRC-97-004 (Exhauster \& Interlock System design).

a. Complete Requirements Checklist (to become Design Compliance Matrix (DCM)).

b. RCR comment resolution meeting.

NEW ACTIVITIES:

1. ---NONE---

NEXT MEETING:

1. -- TBD---

ACTION ITEM SUMMARY:

Page $5.5-10$ 
HNF-2369

Rev. 0

\section{AGENDA \\ DESIGN REVIEW COMMITTEE MEETING \\ CHARACTERIZATION EQUIPMENT \\ MARCH 5, 1997}

MEETING MINUTES:

1. Read and approve $02 / 28 / 97$ meeting minutes.

2. Actions to prior meeting minutes.

CONTINUING ACTIVITIES:

1. Review \#DRC-97-004 (Exhauster \& Interlock System design).
a. Action Items.
b. RCR comment status.

NEW ACTIVITIES:

1. Review \#DRC-97-006 (ECNs resulting from Review \#DRC-97-004)

a. ECN\# , Vacuum pump shutdown addition. Briefing, RCR
comments, coment resolution.

NEXT MEETING:

1. ---TBD---

ACTION ITEM SUMMARY: 
HNF-2369

Rev. 0

\section{AGENDA \\ DESIGN REVIEW COMMITTEE MEETING \\ CHARACTERIZATION EQUIPMENT \\ MARCH 13,1997}

MEETING MINUTES:

1. Read and approve 03/05/97 meeting minutes.

2. Actions to prior meeting minutes.

\section{CONTINUING ACTIVITIES:}

1. Review \#DRC-97-006 (ECNs resulting from Review \#DRC-97-004)

a. ECN\# 631342, Vacuum pump shutdown addition. Complete RCR comment resolution.

b. Design Review Checklist.

2. Review \#DRC-97-004 (Exhauster \& Interlock System design).
a. Action Items.
b. RCR comment resolution.
c. RCR comment status.
d. Design Compliance Matrix (DCM).
e. Design Review Checklist.

\section{NEW ACTIVITIES:}

1. ---none---

NEXT MEETING:

1. $-\cdots$ TBD-..

ACTION ITEM SUMMARY: 


\section{AGENDA \\ DESIGN REVIEW COMMITTEE MEETING \\ CHARACTERIZATION EQUIPMENT}

MARCH 20, 1997

\section{MEETING MINUTES:}

1. Read and approve 03/13/97 meeting minutes.

2. Actions to prior meeting minutes.

CONTINUING ACTIVITIES:

1. Cognizant Design Engineer change for Exhauster System.

2. Review \#DRC-97-006 (ECNs resulting from Review \#DRC-97-004)

a. ECN\# 631342, Vacuum pump shutdown addition. CANCELLED.

3. Review \#DRC-97-004 (Exhauster \& Interlock System design).
a. Action Items.
b. RCR comment resolution.
c. RCR comment status.
d. Design Compliance Matrix (OCM).
e. Design Review Checklist.

NEW ACTIVITIES:

1. ---none---

NEXT MEETING:

$1 . \quad--T B D---$

ACTION ITEM SUMMARY: 
HNF-2369

Rev. 0

\section{AGENDA \\ DESIGN REVIEW COMMITTEE MEETING \\ CHARACTERIZATION EQUIPMENT}

MARCH 27, 1997

MEETING MINUTES:

1. Read and approve 03/20/97 meeting minutes.

2. Actions to prior meeting minutes.

CONTINUING ACTIVITIES:

1. Meeting objectives (GP Janicek/CE Hanson)

2. Exhauster System design re-direction

a. Path-forward overview (CE Hanson)

b. Exh. Sys responsible design engineer(s) designation.

c. Re-direction details (resp. des. engr.)

3. Exhauster System open issues.

a. DRC overview (GP Janicek)

b. RCRs and specific issue areas (indiv. DRC members)

4. DRC review \#DRC-97-004 interim activities (housekeeping)

a. Action Items.

b. RCR comment resolution.

c. RCR comment status.

d. Design Compliance Matrix (DCM).

e. Design Review Checklist.

\section{NEW ACTIVITIES:}

1. ---none---

NEXT MEETING:

1. - - - TBD---

ACTION ITEM SUMMARY:

Page 5.5 - 14 
HNF-2369

Rev. 0

\section{AGENDA \\ DESIGN REVIEW COMMITTEE MEETING \\ CHARACTERIZATION EQUIPMENT}

JULY 10,1997

\section{MEETING MINUTES:}

1. Previously met on $03 / 27 / 97$ - dispense with meeting minutes. Distribute previous meeting agenda, in lieu of.

\section{CONTINUING ACTIVITIES:}

1. Meeting objectives (Janicek)

2. Exhauster System design re-direction (Criddle)

a. Authorization Basis.

b. Design impacts.

3. Existing \#DRC-97-004 RCR's.

a. Status. (Janicek)

b. DRC-97-004 vs. DRC-97-004a. (Criddle)

4. Review/Resolution/Approval of ECNs Ṕ42940, 642941. (Daniels)

5. Review/Resolution/Approval of DRC-97-004a RCRs. (Criddle)

NEW ACTIVITIES:

1. ECNs 942940,642941 per DRC-97-004b. (see item 4 above)

NEXT MEETING:

1. $\quad--T B D-\cdots$

\section{ACTION ITEM SUMMARY:}


HNF-2369

Rev. 0

\section{AGENDA \\ DESIGN REVIEW COMMITTEE MEETING \\ CHARACTERIZATION EQUIPMENT}

AUGUST 7, 1997

\section{MEETING MINUTES:}

1. Previously met on $07 / 10 / 97$ - dispense with meeting minutes. Distribute previous meeting agenda, in lieu of.

CONTINUING ACTIVITIES:

1. Meeting objectives - Design Review Closure (Janicek)

2. DRC-97-004a RCR's completed (Criddle)

3. Design Compliance Matrix completion (A11)

4. Design Review Checklist completion (All)

NEW ACTIVITIES:

1. Design Review Report (Janicek)

NEXT MEETING:

1. ---none---

ACTION ITEM SUMMARY:

Page 5.5 - 16 
HNF-2369

Rev. 0

AGENDA

DESIGN REVIEW COMMITTEE MEETING

CHARACTERIZATION EQUIPMENT

SEPTEMBER 9, 1997

\section{MEETING MINUTES:}

1. Previously met on $08 / 07 / 97$ - dispense with reading of meeting minutes. DSI, GP Janicek to DH Shuford on "Closure of Exhauster "C" Formal Design Review", dated 08/08/97, attached.

CONTINUING ACTIVITIES:

1. N.0.C. Status, RMCS Exhauster \& SX Farm Exhauster. (Janicek)

2. Meeting objectives - Approve new ECNs. (Janicek)

3. DCM - 2nd Unapproved Draft. (Janicek)

4. Review/Resolution/Approval of ECNs, $631344,45,46$.

\section{NEW ACTIVITIES:}

1. - - TBD---

NEXT MEETING:

1. - --TBD---

ACTION ITEM SUMMARY: 
HNF-2369

Rev. 0

AGENDA

DESIGN REVIEW COMMITTEE MEETING

CHARACTERIZATION EQUIPMENT

SEPTEMBER 10, 1997

\section{MEETING MINUTES:}

1. Previously met on $09 / 09 / 97$ - No minutes. Continuation of $09 / 09 / 97$ DRC meeting to be documented by same set of minutes.

\section{CONTINUING ACTIVITIES:}

1. Continue review/resolution/approval of ECNs, $631344,45,46$, review \#DRC-97-004c. (Wilson, Kostelnik)

2. Close Design Compliance Matrix checklist for DRC-97-004c. (DRC)

NEW ACTIVITIES:

1. Review/resolution/approval of ECN 642911, review \#DRC-97-004d. (Akers)

NEXT MEETING:

1. ---TBD---

ACTION ITEM SUMMARY: 
HNF-2369

Rev. 0

AGENDA

DESIGN REVIEW COMMITTEE MEETING

CHARACTERIZATION EQUIPMENT

OCTOBER 23, 1997

\section{MEETING MINUTES:}

1. Previously met on $09 / 10 / 97$ - Review/Comment Resolution for ECNs $631344,45,46$, and 642911 .

\section{CONTINUING ACTIVITIES:}

1. --none-r-

\section{NEW ACTIVITIES:}

1. Meeting scope. (GPJ)

2. Overview of changes necessitated by "Major Stack" designation. (Criddle)

3. Exhauster "Major Stack" Mods - Review/comment resolution/approval of ECN 642928. (Akers/Wilson)

4. DCM checklist verification. (All)

NEXT MEETING:

1. ---TBD---

ACTION ITEM SUMMARY: 
HNF-2369

Rev. 0

\subsection{DESIGN REVIEW COMMITTEE MEETING MINUTES}

Page 5.6 - 1 
MEETING MINUTES

Subject: Formal Design Review

TO: Distribution

BUILDING $2704 \mathrm{HV} / \mathrm{G} 230$

FROM: G. Tom Frater, 373-1627

Secretary

CHAIRMAN G. P. Janicek, 376-2225

Department-0peration-

Component

Characterization Equipment

Engineering Projects

Area Sumber

200E Day February 20, $1997 \quad 7$

Attendees:

$\begin{array}{llllll}\text { M. L. McElroy (LMHC) } & \text { S7-07 } & \text { C. C. Scaief } & \text { (LMHC) } & \text { R1-56 } \\ \text { J. A. Ranschau (LMHC) } & \text { R1-56 } & \text { T. D. Jarecki } & \text { (LMHC) S7-03 } \\ \text { G. T. Frater (LMHC) } & \text { S7-16 } & \text { G. P. Janicek } & \text { (LMHC) S7-12 } \\ \text { J. D. Robinson (SESC) } & \text { S7-12 } & & & \end{array}$

Approved Meeting Minutes? ay thas than

The meeting was called to order by George Janicek at 12:35 pm.

Meeting minutes from the previous meeting are not yet available will be reviewed and approved after they are brought in later during this meeting.

$\mathrm{Jim}$ Robinson is present to obtain approval signatures on direct revision ECN 639110, to WHC-SD-WM-CS-DD-020, Rev 1. George Janicek and Mike MCElroy signed the ECN.

Questions presented to Jim Robinson since he was present and available to respond.

Question: Will the Allen Bradley (Vendor) variable frequency drive for the exhauster fan withstand the ambient operating conditions outside i.e. $-20 \mathrm{~F}$ to $115 \mathrm{~F}$ at Hanford. Jim said the device is installed in a NEMA IV cabinet and is rated by the vendor for $32 \mathrm{~F}$ to $110 \mathrm{~F}$. Also the exhausters with this same drive unit have already operated for several years at Hanford demonstrating successful year around service in ambient conditions. To provide further assurance for qualified operation Chuck Scaief provided a suggestion on how to qualify the device for the full temperature range with standard formulas for heat transfer available in a manufacturers catalog which chuck named.

Discussion on whether the humidity instrument and a pressure switch are explosion proof. No actions assigned.

ACTION: Jim Robinson agreed to talk to Ron Bafus (COG) for the wording in the calibration procedure on temperature value for the WEC.

Chuck Scaief responded to an earlier action to present the conductivity value for the duct material connecting the spool piece and the tank riser. Chuck said it is drainable provided volume resistivity is less than $10^{12}$ ohms-sq or surface resistivity is less than $10^{12}$ ohms per sa as it relales lo an electrical charge accumulation. Follow up action for this subject will be covered by the upcoming scheduled design review.

Page $5.6-2$ 
George presented a comment from Will Pickett. The water heater circulation pump has an apparent limitation for indoor service?

Jim Robinson said that the pump and motor are rated for outside service but the electrical power connection box is not rated for outdoor use so an ECN to fabricate a protection shield for the connection box is now in progress.

We are committed to begin the design review on the exhauster and the interlock carts. RCR comments are due to the secretary by COB on Wednesday 2-26-97. An all day design review meeting will be held on Friday 2-28-97.

A question was raised before Jim Robinson was to leave. Chuck asked how many portable exhausters exist at Hanford (like the one modified for truck \#4) to be used for tank service?

Jim answered that there are 3 total exhausters in Characterization and 1 interlock that is completed. Another interlock system is planned for fabrication at H\&N electric in Pasco, with some of the equipment items located at Los Alamos. Merrick is the contractor but the task is on hold pending approval/funding issues to be resolved. of the 3 total exhausters 1 exhauster is located/on loan at 244 AR Vault.

Exhauster "A" (for truck \#2) is at 244 AR Vault.

Exhauster "B" (for truck \#3) is yet to be modified.

Exhauster "C" (for truck \#4) is modified.

The drawings for \#3 and \#4 exhauster modifications are identical.

George handed out the insert pages, with changes made, for the Design Requirements list produced by Nancy Milliken. We reviewed the list starting on page 7 . Revised copies will be distributed to committee members electronically.

Determined that the SEL should be reviewed separately i.e. independently of the charter we are currently adhering to. We agreed for now to accept the SEL as is and later recommend a later review.

George Janicek handed out the one page list of individual responsibilities for the upcoming design review. Changes were noted and George agreed to make them and redistribute the list Friday 2-21-97.

A discussion of the $90 \mathrm{MPH}$ requirement for the exhauster stack is not in the SAD-035 but was added by engineering to protect nearby equipment in the tank farm if the exhauster should topple during a wind storm.

Read the meeting minutes from the previous meeting on 2-14-97. Marked a number of editorial changes to be made by the secretary. Will resubmit the minutes at the next meeting for approval.

Next meeting is February 28, 1997, 8 am to $4: 30 \mathrm{pm}$, location per LANCAL.

Meeting was adjourned at $3: 35 \mathrm{pm}$.

ATTACHMENTS (1): Attendance Roster

Page $5.6-3$ 
HNF-2369

Rev. 0

$2 \cdot 20 \cdot 97$

12:30/Room 6-230

NAME

Michael L. MSElroy

Jeff Ranschau

Tom Frater

Jim Robinson

Chuck Scaief

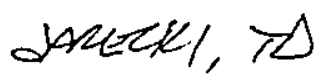

GPotionicotí
org/Co.

CPQA/LMHC

CPS/LMHC

c Poffice/ LmHC

SESC/ CEF

LMNC

cmre

CMHC
Phone

$373-5588$

$373-4462$

5731627

$6-4717$

$6-0491$

3.5741

c-2225

Page 5.6- 4 


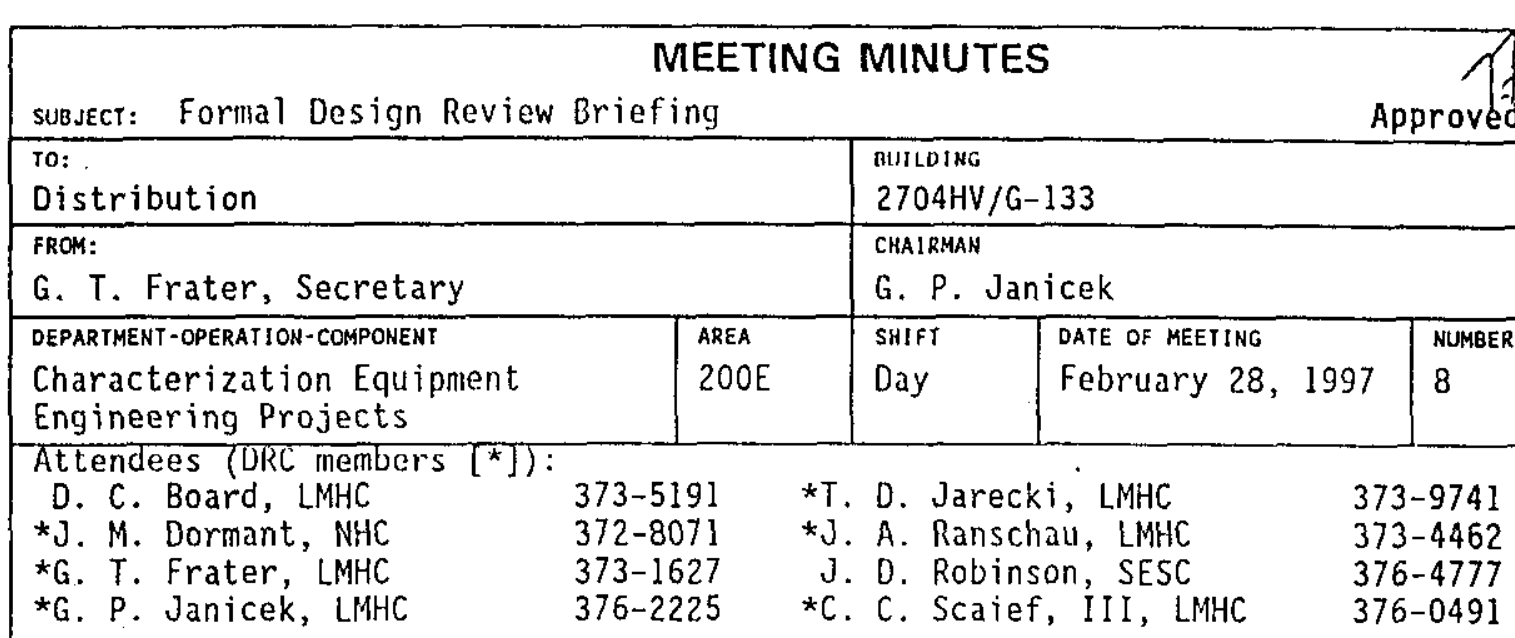

Members absent: J. R. Kriskovich, M. L. McElroy, N. J. Milliken

The meeting was called to order by George Janicek at 8:10 am. The agenda for today's meeting was distributed.

1. Handed out the meeting minutes from previous meetings, 2-18-97 and 2-19-97, for review and approval. Meeting minutes from 2-18-97 were approved with comments and the minutes from 2-19-97 were approved as written.

2. Handed out a copy of the Excel file for a draft "Design Compliance Matrix" titled DCM-Exhauster System. This is a checklist developed to meet one of the recommendations from the Review of Characterization Engineering, Hydrogen Exhauster Interlock System Design Process Final Report. This matrix will ensure each requirement is addressed and will document the evidence that each item was reviewed.

3. We went through each numbered item on the matrix and assigned closure responsibility. Two of the matrix columns, "Engineering Evaluation Description" and "Verified By", will document how each criteria was met or how the condition or requirement is achieved.

4. Assigned each item to a responsible primary person. Those assignments will be added to the Excel table by George Janicek.

5. Decided to have, as a minimum, a primary and secondary name responsible for each requirement.

6. Jim Robinson was asked to get a copy of DOE Order 6430.1A interpretation letter for the file. This is an interpretation to exclude the design from DOE order $6430.1 \mathrm{~A}$ requirements as not applying to the portable exhauster design. Jim brought a copy of the letter to the meeting after the first break.

7. Jim Robinson's presentation, "RCR Comments and Preliminary Resolution"

First topic: Flame Arresters, purpose is to bring the committee up to date. Air Monitor Corporation. (CVI) drawing system schematic shown on overhead.

Vacuum pumps and 2 pressure switches (NFPA 69) are unprotected.

Chuck Scaief made a suggestion to add a block or isolation valve ahead of the vacuum pump tubing to serve as a barrier. Jim Robinson will pursue (liked the idea). 
HNF-2369

Started RCR comments and proposed resolution:

1. Jeff Ranschau

Note: Comment \#3, Jeff is to add the source of information that led to making the comment i.e. the source of the requirements

2. George Janicek comments

Discussion notations made by Jim Robinson; will be dispositioned.

3. Mike McElroy

Could not disposition \#1; need further information (Don Board representing QA;

Mike McElroy was not present.).

4. Tom Frater comments

Note: FDC addresses the tank contaminants, see appendix.

5. Chuck Scaief comments; will be dispositioned.

General Comments" listing, no need to respond by the DRC. For information, will include in the Design Review Report.

6. Ted Jarecki comments; will be dispositioned.

7. Nancy Milliken comments (Nancy not present today.)

Jim Robinson to meet with Nancy Milliken to resolve comments since some of them require her participation. Jim to share the comments with Jim Kriskovich, for his input and participation.

8. Jean Marc Dormant comments; will be dispositioned.

If variable frequency drive is subject to operating conditions in a non-conditioned enclosure exceeding the recommended vendor operating range, it could fail. Rewrite the RCR comment to ask this question. ACTION: Jean Marc Dormant is to submit this rewritten RCR comment. Jim would like a list (or help with identifying activities or actions resulting from the Design Review to be labeled as "pre-start" or "post-start." Specifically, Jim Robinson asks for help with doing so. George Janicek says not our call; however, previous direction from Rick Raymond has been all activities are "prestart" until otherwise directed.

ACTION: Jim Robinson is to obtain single point failure analysis to Chuck scaief and Tom Frater

ACTION: Jim Robinson to obtain CVI drawings, CVI \#22660 specifically flow diagrams for items in contact with exhauster gas flow.

ACTION: Ted Jarecki is to obtain a copy of the OTP.

Jim Robinson needs 1 full day following receipt of RCR comments to properly address them.

George Janicek to DRC, ACTION: ALL committee members

Send conments as they are generated in groups, i.e. several, to minimize the impact on Jim Robinson by Wednesday of next week 3-5-97.

George Janicek asked each member to determine the number of actual hours to complete the overall review and a calendar date for completion.

ECNs pending review:

- Spool piece

- Drawing changes for clarification (not required)

- Block valve flow from vacuum pumps

George Janicek adjourned the meeting at 1:45 p.m.

Attached is a list of hours to complete and the completion date. 
HNF-2369

Rev. 0

ATTACHMENT to Meeting Minutes, February 28, 1997

Formal Design Review Briefing

Page 5.6 - 7 
HNF-2369

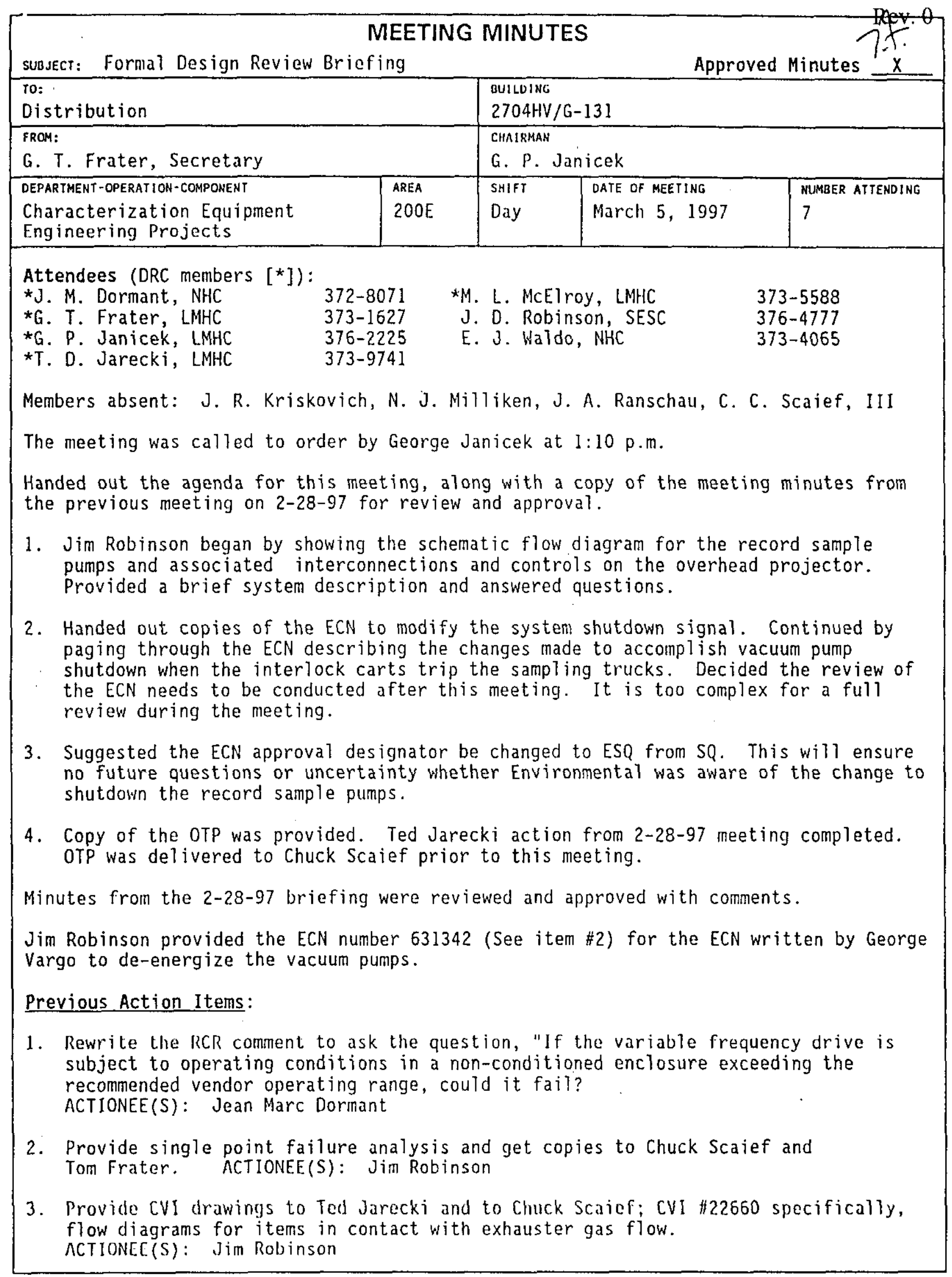

$A \cdot 3000 \cdot 680(10 / 9 / 4)$ CEEF011

Page 5.6 - 8 


\section{Previous Action Items (cont.):}

4. Provide a copy of the OTP. ACTIONEE(S): Ted Jarecki

DUE DATE: COMPLETE

5. Send comments as they are generated in groups, i.e. several comments. Don't hold all comments until the last day in order to minimize the impact on Jim Robinson. ACTIONEE(S): All comititee members DUE DATE: $3 / 5 / 97$

6. George Janicek asked each committee member to determine the number of actual hours to complete the overall review and a calendar date for completion.

\section{New Action Items:}

Reminder from George Janicek to complete remaining open action items from the 2/28/97 meeting.

ACTIONEE(S): Committee members with listed actions.

Next Meeting: TBD

Meeting adjourned at 2:01 p.m. 


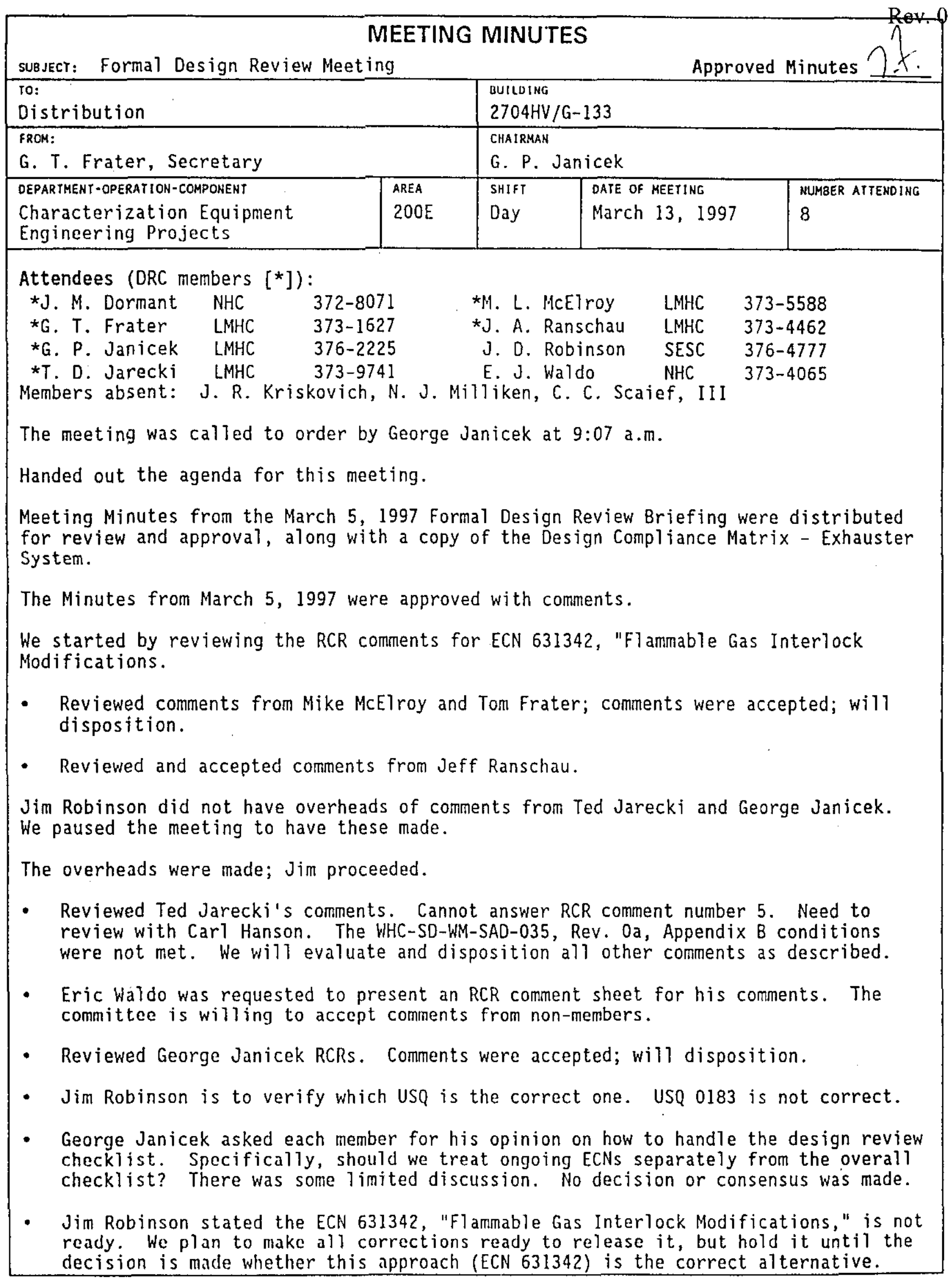


HNF-2369

Rev. 0

MEETING MINUTES (Continued)

Page 3 of 3

New Action Items:

1. Send a copy of all RCR comments to the members that could not be present for this meeting.

ACTIONEE(S): Tom Frater DUE DATE:

2. Provide the ECN for the overall water heater system to the committee. ACTIONEE(S): Jim Robinson DUE DATE:

Meeting adjourned at 11:45 a.m.

Next meeting: TBD

Attachment: Design Compliance Matrix - Exhauster System 
MEETING MINUTES

subject: Formal Design Review Meeting

\begin{tabular}{|c|c|c|c|c|c|c|}
\hline \multicolumn{3}{|l|}{$\begin{array}{l}\text { TO: } \\
\text { Distribution }\end{array}$} & \multicolumn{4}{|c|}{$\begin{array}{l}\text { BUILDING } \\
2704 \mathrm{HV} / \mathrm{G}-108 \mathrm{~A}\end{array}$} \\
\hline \multicolumn{3}{|c|}{$\begin{array}{l}\text { FROM: } \\
\text { G. T. Frater, Secretary }\end{array}$} & \multicolumn{4}{|c|}{$\begin{array}{l}\text { CHAIRMAN } \\
\text { G. P. Janicek }\end{array}$} \\
\hline \multicolumn{2}{|c|}{$\begin{array}{l}\text { DEPARTMENT-OPERATION-COMPONENT } \\
\text { Characterization Equipment } \\
\text { Engincering Projects }\end{array}$} & $\begin{array}{l}\text { AREA } \\
200 E\end{array}$ & $\begin{array}{l}\text { SHIFT } \\
\text { Day }\end{array}$ & \multicolumn{2}{|c|}{$\begin{array}{l}\text { DATE OF MEETING } \\
\text { March } 20,1997\end{array}$} & $\begin{array}{l}\text { NUMBER } \\
11\end{array}$ \\
\hline \multicolumn{7}{|c|}{ Attendees (DRC members $\left[{ }^{\star}\right]$ ): } \\
\hline *J. M. Dormant & $\mathrm{NHC}$ & $372-8071$ & $\star J$ & inschau & LMHC & $373-446$ \\
\hline${ }^{*}$ G. T. Frater & LMHC & $373-1627$ & J. & binson & SESC & $376-477$ \\
\hline *G. P. Janicek & LMHC & $376-2225$ & ${ }^{*} \mathrm{C}$. & aief & LMHC & $376-049$ \\
\hline *J. R. Kriskovich & LMHC & $373-9741$ & G. & irgo & SESC & $376-5387$ \\
\hline *M. L. McElroy & LMHC & $373-5588$ & E. & 1 do & $\mathrm{NHC}$ & $373-4065$ \\
\hline
\end{tabular}

*N. J. Milliken DESH 376-7846

Members absent: T. D. Jarecki

The meeting was called to order by George Janicek at 1:04 p.m.

Handed out the agenda for this meeting and Meeting Minutes from the last meeting on March 13, 1997 for review and approval.

Meeting Minutes from the March 13, 1997 Formal Design Review Briefing were approved with one change as a result of the departure of Jim Robinson to a new job offsite. Action item \#2 (See "New Action Items") is to be reassigned to Will Pickett.

Continuing Activities

Item 1: Jim Robinson stated that George Vargo is to assume some of his immediate responsibilities, eg., the ECN for the short term fix for the vacuum pumps that collect the record samples from the stack. Another ECN is on its way for review: change the water heater to a vertical orientation to match vendor's mounting recommendations. The water heater is located on the exhauster to preheat vapor stream passing through the exhauster HEPA filters.

Item 2: The ECN 631342, "Flammable Gas Interlock Modifications" design has been cancelled. To be replaced with a new approach with ECN under development by George Vargo with an estimated 90-day completion schedule.

Item 3: Review DRC-97-004 (Exhauster and Interlock System Design)

a. Reviewed Action Items due.

b. Discussed RCR Comment resolution.

Read some comments from Jeff Ranschau.

Read comments from Tom Frater.

Motor bearings are factory sealed. Calculations for wire sizing, in particular, the fan motor, including in-rush current sized properly. Jim Robinson said no codes but field measurements made are 22, 15, 22 amps each leg, as of the field trip on August 1996. Tom Frater asked about request for NEC code inspections. Jim realized he was working from an old version of the RCR. Need to get the current revision.

Reviewed Nancy's comments. Seven of twelve are closed and 5 remain open. Reviewed Jim Kriskovich RCR Comments. Discussion on interpretation of rafarancad documentation 
HNF-2369

George Janicek stated that he wants to close all possible RCR comments that each author and $\operatorname{cog}$ engineer Jim Robinson agree on. The question was asked, "Who will be responsible to close the remaining open items?" Jim Robinson said he will talk to Carl Hanson about this assignment and will make a copy of all his (Jim Robinson's) responses to RCR comments and forward to Tom Frater before he leaves the company.

Agreed we cannot yet close out the design review.

Jim Robinson made changes to some RCR comment resolutions. Presented these to the originators in order to close out the items that are in agreement.

Each member with remaining open RCR items will add any notations and send electronic copies to Tom Frater.

\section{Previous Action_Items:}

1. Provide CVI drawings to Ted Jarecki and to Chuck Scaief; CVI \#22660 specifically, flow diagrams for items in contact with exhauster gas flow.

ACTIONEE(S): Jim Robinson DUE DATE: COMPLETED

2. Provide a copy of the OTP. ACTIONEE(S): Ted Jarecki

DUE DATE: COMPLETED

3. Rewrite the RCR comment to ask the question, "If the variable frequency drive is subject to Hanford operating conditions, installed a non-conditioned enclosure exceeding the recommended vendor operating range, could it fail? ACTIONEE(S): Jean Marc Dormant

4. Provide single point failure analysis and get copies to Chuck Scajef and Tom Frater. ACTIONEE(S): Jim Robinson

5. Send comments as they are generated in groups, i.e. several comments. Don't hold all comments until the last day in order to minimize the impact on Jim Robinson. ACTIONEE(S): AII committee members

6. George Janicek asked each committee member to determine the number of actual hours to complete the overall review and a calendar date for completion. This was obtained per telecon. ACTIONEE(S): All committee members

7. Reminder from George Janicek to complete remaining open action items from the 2/28/97 meeting. ACTIONEE(S): Committee members with listed actions.

8. Send a copy of all RCR comments to the members that could not be present for this meeting.

ACTIONEE(S): TOM Frater DUE DATE:

9. Provide the ECN for the overall water heater system to the committee. ACTIONEE(S): Jim Robinson DUE DATE:

New Action Items:

None

Next meeting: TBD 
HNF-2369

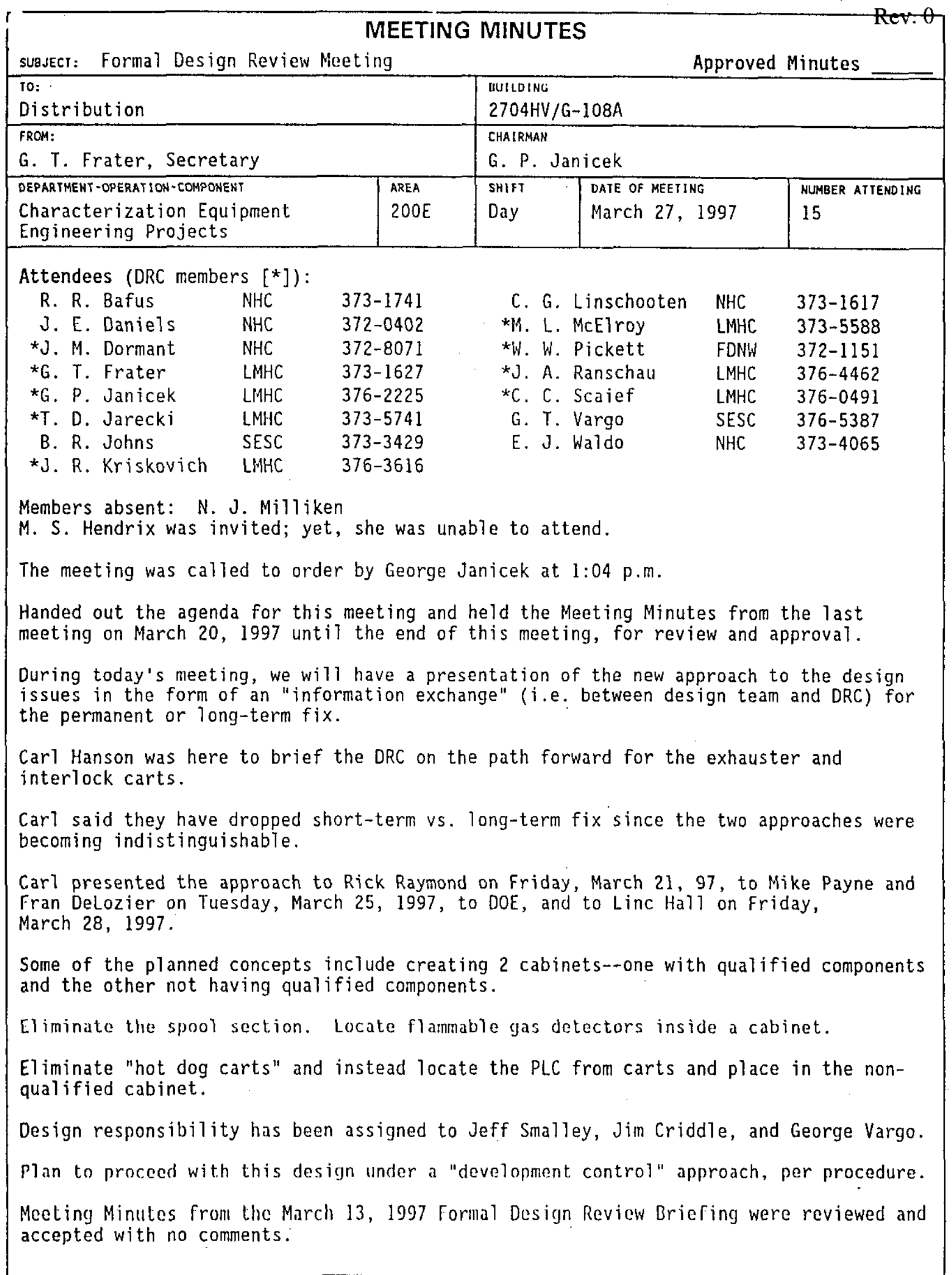


HNF-2369

Rev. O

Remaining individuals that owe their final and best RCRs with disposition "accepted" or "not accepted" are Jim Kriskovich and Jeff Ranschau.

Plan to publish an interim status for the design review committee, representing where we are as of this juncture.

Committee remains intact with all existing members. We will be "on hold" pending a decision on which direction the design team will proceed. There are scveral

al ternatives under consideration.

Meeting adjourned at 2:28 p.m.

New Action Items:

Send copies of Ted Jarecki RCRs to each of the design engineers present (9): $R$. R. Bafus (didn't keep), J. D. Criddle, Jr., J. E. Daniels, B. R. Johns, A. J. Kostelnik, C. G. Linschooten, J. L. Smalley, G. F. Vargo, and E. J. Waldo. ACTIONEE(S): TOM Frater

\section{Previous Action Items:}

1. Rewrite the RCR comment to ask the question, "If the variable frequency drive is subject to Hanford operating conditions, installed a non-conditioned enclosure exceeding the recommended vendor operating range, could it fail?

ACTIONEE(S): Jean Marc Dormant DATE DUE: COMPLETED

2. Provide single point failure analysis and get copies to Chuck Scaief and Tom Frater. ACTIONEE(S): George Vargo

3. Send a copy of all RCR comments to the members that could not be present for this meeting.

ACTIONEE(S): Tom Frater DUE DATE: COMPLETED

4. Provide the ECN for the overall water heater system to the committee.

ACTIONEE(S): Jim Robinson DUE DATE: ON HOLD

Next meeting: TBD 


\begin{tabular}{|c|c|c|c|c|c|}
\hline \multicolumn{6}{|c|}{ MEETING MINUTES } \\
\hline \multicolumn{3}{|c|}{$\begin{array}{l}\text { Do: } \\
\text { Distribution }\end{array}$} & \multicolumn{3}{|c|}{$\begin{array}{l}\text { BUILDING } \\
2704 \mathrm{HV} / \mathrm{AlO}\end{array}$} \\
\hline \multicolumn{3}{|l|}{$\begin{array}{l}\text { FROM: } \\
\text { G. P. Janicek, } 376-2225\end{array}$} & \multicolumn{3}{|c|}{$\begin{array}{l}\text { CHAIRMAN } \\
\text { G. P. Janicek, 376-2225 }\end{array}$} \\
\hline \multicolumn{2}{|l|}{$\begin{array}{l}\text { DEPARTMENT-OPERATION-COMPONENT } \\
\text { Characterization Project } \\
\text { Characterization Engineering }\end{array}$} & AREA & $\begin{array}{l}\text { SHJFT } \\
\text { Day }\end{array}$ & $\begin{array}{l}\text { DAIE OF MEETING } \\
\text { August } 14,1997\end{array}$ & $\begin{array}{l}\text { NUMBER ATTENDING } \\
6\end{array}$ \\
\hline \multicolumn{6}{|c|}{ 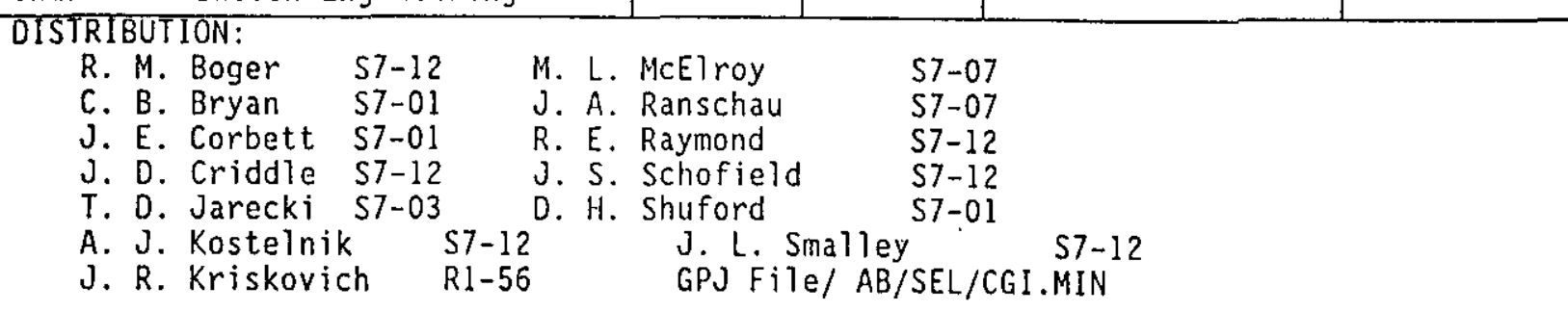 } \\
\hline \multicolumn{6}{|c|}{ 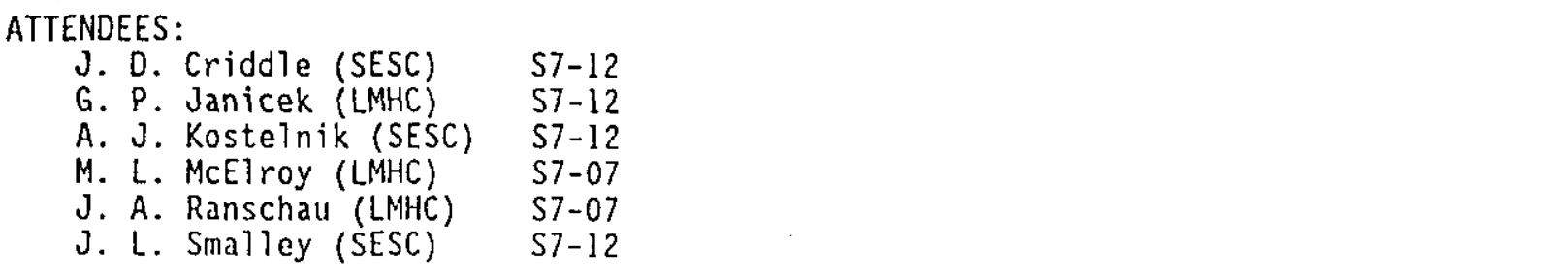 } \\
\hline \multicolumn{6}{|c|}{$\begin{array}{l}\text { Meeting scheduled by GP Janicek (meeting notice attached). Meeting convened at 8:40 } \\
\text { am. }\end{array}$} \\
\hline \multicolumn{6}{|c|}{ MEETING PURPOSE } \\
\hline \multicolumn{6}{|c|}{$\begin{array}{l}\text { The purpose of the meeting was to reconcile that the revised AB controls were fully } \\
\text { design implemented by a necessary and sufficient set of safety SSCS as identified in } \\
\text { the new SEL, and had proper CGI dedication documentation. Reconciliation was planned } \\
\text { and felt to be necessary due to the fact that the three activities of AB changes, SEL } \\
\text { revision (new), and CGI documentation are normally performed in series, but, in this } \\
\text { instance had been performed, in the interest of schedule, in parallel. } \\
\text { PROCESS }\end{array}$} \\
\hline \multicolumn{6}{|c|}{$\begin{array}{l}\text { The first item of business was to decide on the process to use for determining } \\
\text { AB/SEL/CGI reconciliation. The group consensus was to not rely on individuals having } \\
\text { performed their respective tasks correctly, although in parallel, even though little } \\
\text { changed between inception and completion of tasks in } A B \text { understanding. Instead, it was } \\
\text { decided to walk through the actual } A B \text { changes, the old and new SEL, and the old and new } \\
\text { documentation of commercial grade items for the designated set of safety SSCs. } \\
\text { The documents examined, and the process used, is depicted in the attached diagram: } \\
\text { The old } A B \text {, SAD-035 (LANL), was used to revise SEL-032, and the CGI } \\
\text { dedication/classification for these safety SSCs was accomplished through a } \\
\text { combination of closed NCRs and safety class procurements PRs. The process assumed } \\
\text { that these previous documents were, themselves, fully reconciled. }\end{array}$} \\
\hline
\end{tabular}

$A \cdot 3000-480(10 / 94)$ GEFO 11 
- ECN revised the $A B$ from SAD-035 (LANL) in its entirety to SAD-035 (LMHC), 0SR-005, $B I 0 / J C 0$, and TSR-006. The process assumed that the BIO/JCO was frozen as of the meeting date.

SEL-044 consists of a combination of new safety SSCS derived from the new AB plus a residual set of safety SSCS identified in SEL-032 representing the non-flammable gas controls originally derived from SAD-035. Some controls which could not be implemented directly were determined to be met or have equivalency by FGEAB rulings.

Out of the four documents establishing the new $A B$, only TSR-006 does not drive safety SSC classification in SEL-044.

The full set of safety SSCS requiring new CGI dedication/classification consists of a portion of the previous NCR'd items and new items derived from SEL-044 directiy. Thus, for RMCS Truck \#4, the set of items originally procured as Safety Class, the set of NCR's remaining after some have been converted to CGIs, together with the new CGIs encompass the full set of safety SSCs identified in SEL-044.

The four documents comprising the new $A B$ also generate SLS, LCOS, and ACs which must be picked up in operations procedures and maintenance procedures. It was assumed that the $A B$ Compliance Matrix preparation activity adequately addressed and reconciled operating procedures and procedure revisions required. Maintenance procedures, specifically calibration procedures (PMS) were reconciled within this process.

ACTIONS ASSIGNED (see attached diagram)

RANSCHAU - Compare ECN to SEL-032. Determine discarded and residual portions of SEL-032. Reconcile residual portion of SEL-032 and FGEAB reports with new SEL-044.

CRIDDLE - Reconcile ECN/OSR-005 with FGEAB reports and SEL-044.

SMALLEY, KOSTELNIK, CRIDDLE - Reconcile ECN/SAD/BIO/JCO with FGEAB reports and SEL044.

JARECKI - Reconcile SEL-044 with PMs.

MCELROY, JANICEK - Reconcile NCRs/PRs/CGIs with SEL-044.

NEXT MEETING

Attendees were requested to reconvene at $3: 00 \mathrm{pm}$ to ascertain action item status.

Initial meeting session adjourned at 10:15 am.

3:00 PM SESSION $(08 / 14 / 97)$

Meeting reconvened at $3: 00 \mathrm{pm}$. Previous session attendees all present. Process diagram revised slightly to that depicted in attachment and described previously. Individual actions statused. Actions incomplete. Will reconvene tommorrow at 11:00 am.

$A-3000-480(10 / 94)$ GEF 011 
$3: 00 \mathrm{pm}$ session adjourned at 4:00 pm. [Chairman's note: JARECKI informed of action item following this session]

\section{1:00 AM SESSION $(08 / 15 / 97)$}

Meeting reconvened at 11:00 am. Previous session attendees all present, except A. J. Kostelnik and M. L. McEiroy. J. R. Kriskovich attended briefly. J. E. Corbett attended for T. D. Jarecki.

Ranschau had list of open items needing clarification, which Smalley satisfactorily addressed. Attendees individually described and statused their action items. Some indiduals were asked to submit [for file purposes] reconciliation backup material (Ranschau, Corbett, Janicek). Agreement of all present that AB/SEL/CGI waS satisfactorily reconciled.

11:00 am session adjourned at 12:00 noon.

REFERENCES

SAD-035 WHC-SO-WM-SAD-035, A SAFETY ASSESSMENT OF ROTARY-MODE CORE SAMPLING IN FLAMMABLE-GAS SINGLE SHELL TANKS: HANFORD SITE, RICHLAND WASHINGTON.

OSR-005 WHC-SD-WM-OSR-005, REV OG, SINGLE SHELL TANK INTERIM INTERIM OPERATIONAL SAFETY REQUIREMENTS.

BIO/JCO WHC-SD-WM-BIO-001, REV G, TANK WASTE REMEDIATION SYSTEM BASIS FOR INTERIM OPERATION.

TSR-006 WHC-SD-WM-TSR-006, REV J, TANK WASTE REMEDIATION SYSTEM TECHNICAL SAFETY REQUIREMENTS.

ECN ECN \#173679, ROTARY MODE CORE SAMPLING AUTHORIZATION BASIS AMENDMENT, $08 / 08 / 97$.

SEL-032 WHC-SO-WM-SEL-032, ROTARY MODE CORE SAMPLING SAFETY EQUIPMENT LIST, 1994.

SEL-044 WHC-SD-WM-SEL-044, REV 0, A SAFETY EQUIPMENT LIST FOR ROTARY MODE CORE SAMPLING SYSTEMS OPERATION IN SINGLE SHELL FLAMHABLE GAS TANKS, 1997. 
HNF-2369

Rev. 0

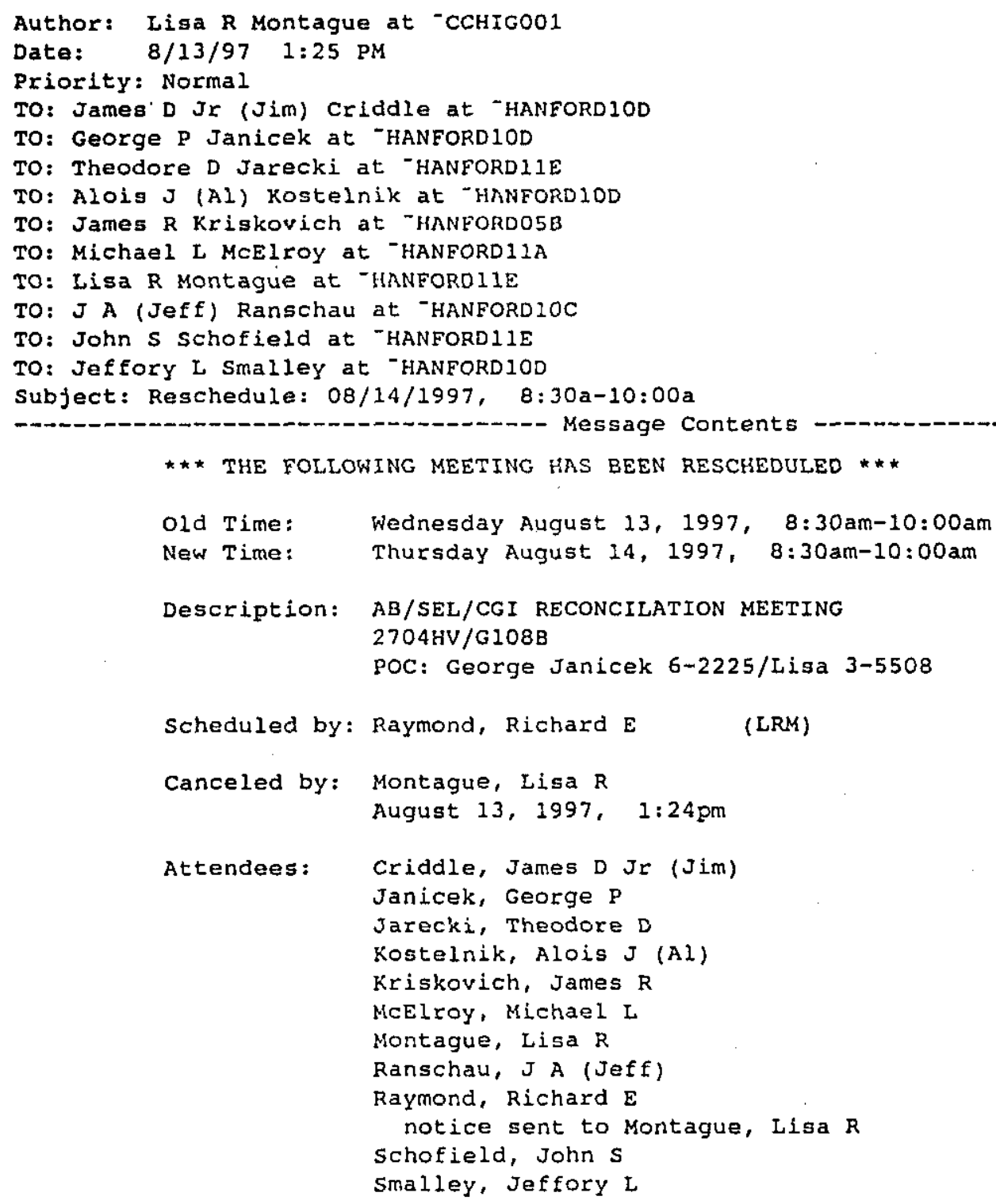


HNF-2369

Rev. 0

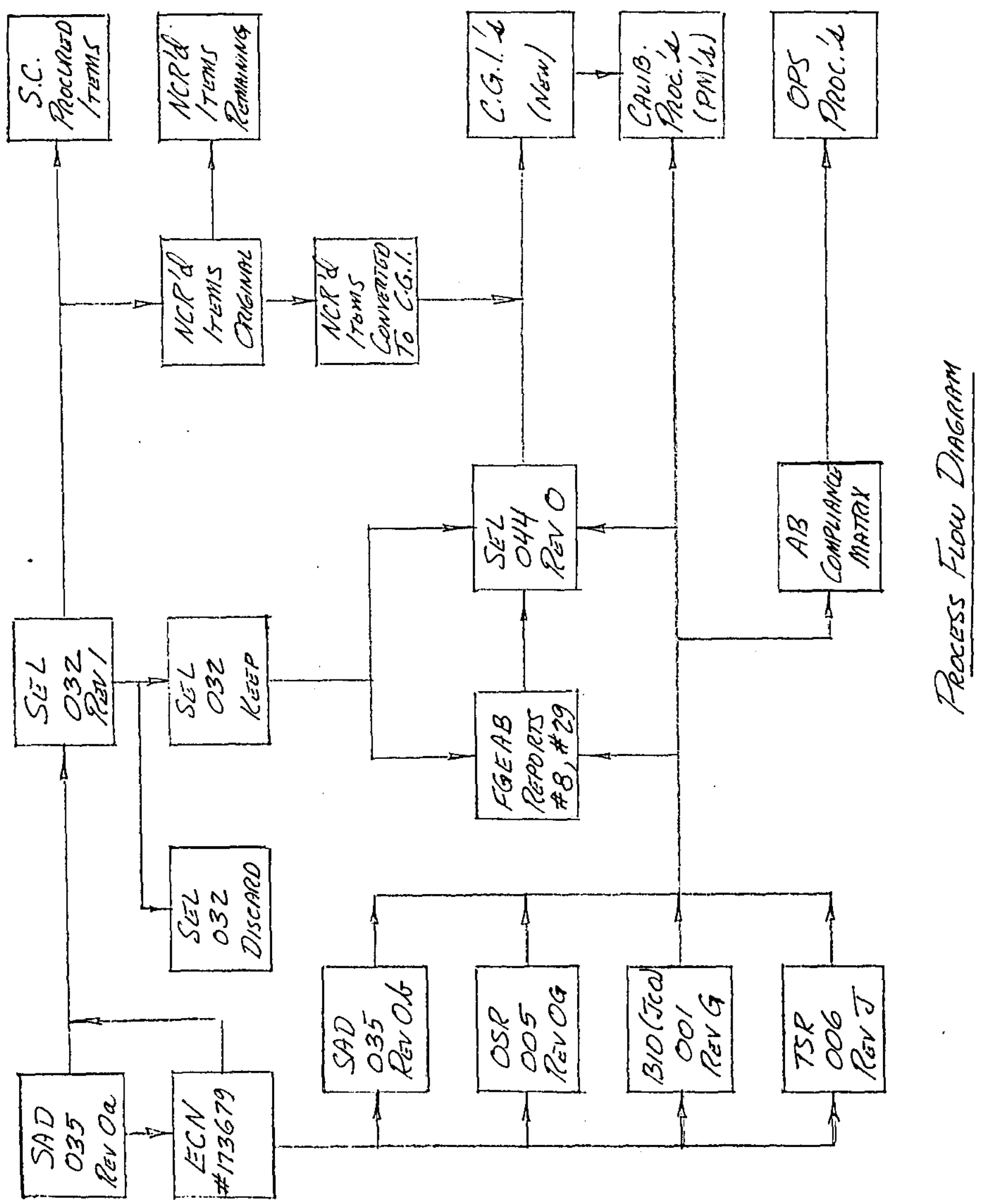

Page 5.6 - 20 


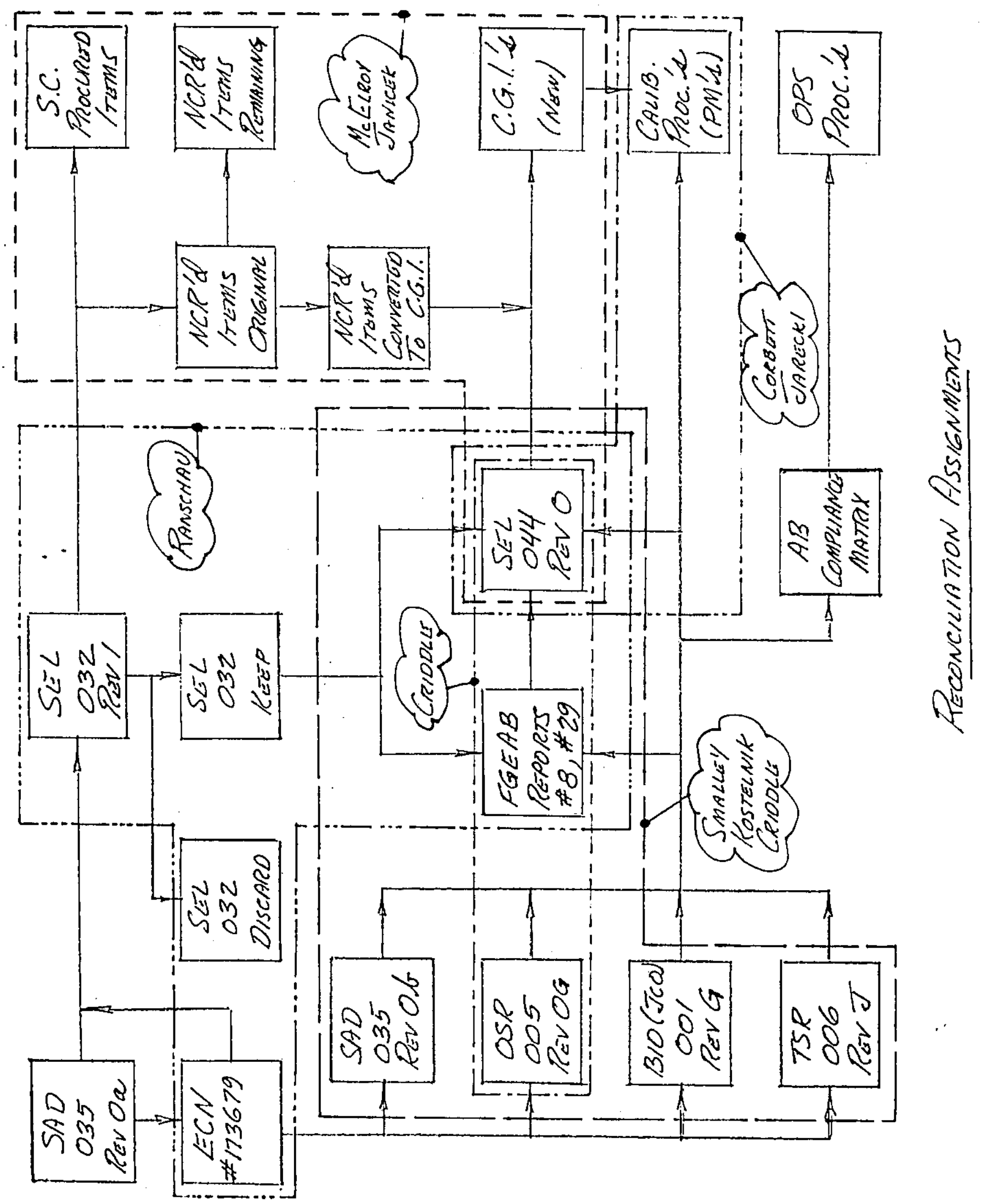

Page 5.6 - 21 


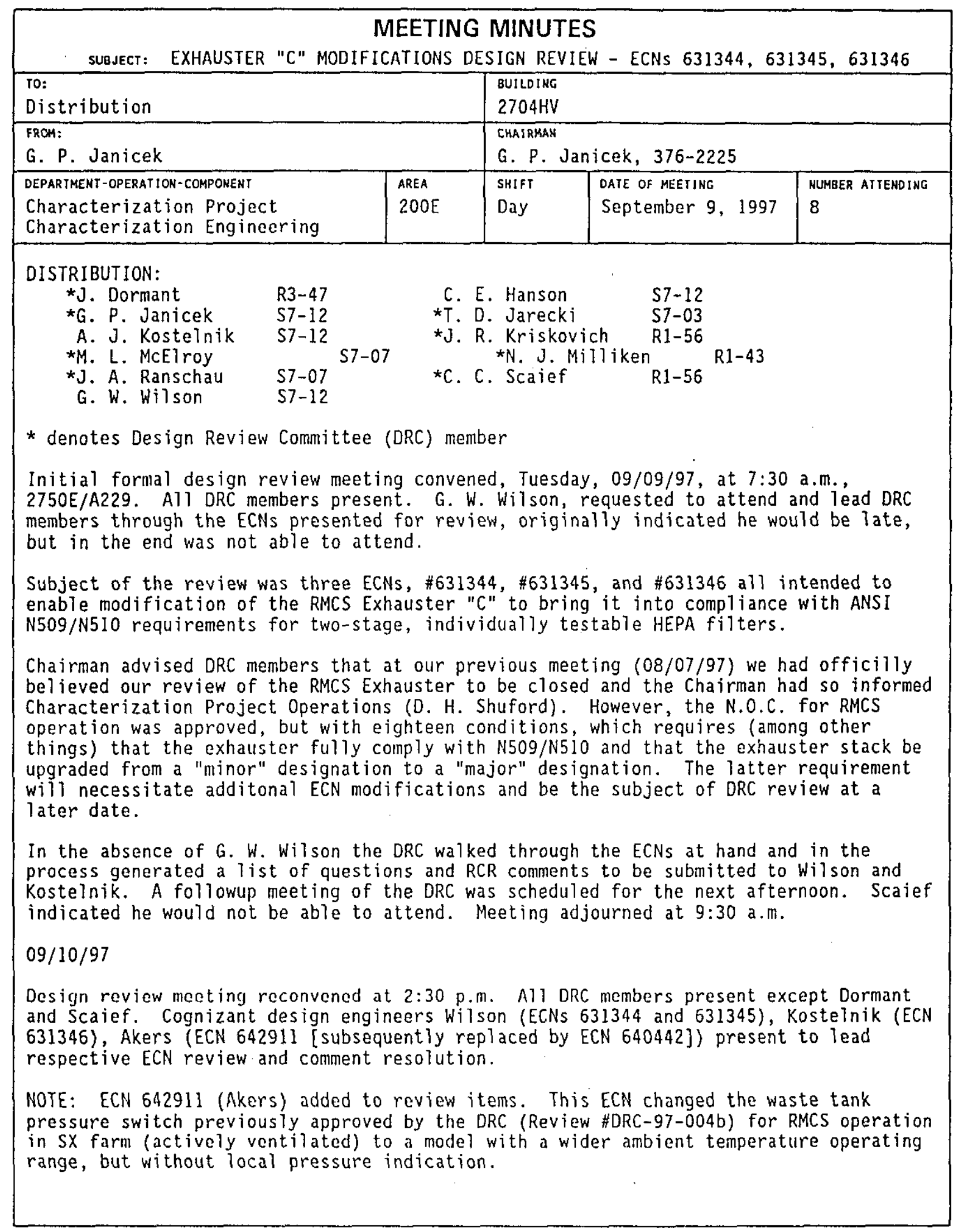

A-3000-480 (10/94) GEF011 
DRC members submitted RCR comments to Wilson/Kostelnik based on previous day's review. Additional comments were generated and submitted in writing at the meeting. Disposition to all comments was agreed to between submitters and cog design engineers. For the Wilson/Kostelnik ECNs, 37 comments were submitted by the DRC and 6 by the cog design engineers themselves.

Akers walked through ECN 642911, and hand recorded DRC comments with agreed-to dispositions on a blank RCR form. Sixteen comments were so submitted and dispositioned.

NOTE: A number of RCR comments had to do with the mechanics of the ECN form itself, a few had to with wording in the USQ accompanying the ECNs.

The cog design engineers agreed to make the necessary ECN changes and get back with the DRC for RCR comment closure by Friday $(09 / 12 / 97)$.

Meeting adjourned at 5:15 p.m.

$09 / 16 / 97$

Akers able to meet with each DRC member submitting comments and obtain comment closure approval. All closed RCR comments are compiled on a single RCR form designated as Review No. DRC-97-004d. Due to the large number of comments and inability to make all changes on the original ECN form numbered 642911, the ECN was redone as ECN \#640442. ECN \#640442 was issued this date.

RCR comment closure for ECNs 632344,45 , and 46 still require Kriskovich and Ranschau approval. Neither was available this date.

$09 / 17 / 97$

$x \times x$ 
5.7 DESIGN REVIEW CLOSURE CORRESPONDENCE W/BACKUP DATA

Page 5.7 - 1 
DON'T SAY IT .... Write It!

TO: $\mathrm{OH}$ Shuford

S7-01

cc:

$\begin{array}{ll}\text { CB Bryan } & \text { S7-01 } \\ \text { RE Raymond } & \text { S7-12 } \\ \text { GPJ File/LB } & \end{array}$

DATE: $08 / 08 / 97$

FROM: GP Janicek

Telephone:

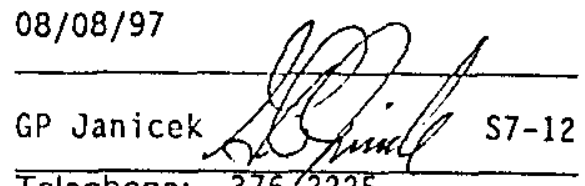

$376-2225$

\section{SUBJECT: Closure of Exhauster "C" Formal Design Review}

The purpose of this DSI is to inform you that the Design Review Committee (DRC) has conpleted its formal design review of Exhauster "C" Safety SSCS, based upon changes being made to the Authorization Basis (AB) for Rotary Mode Core Sampling (RMCS) operation as defined by ECN\# 173679. A few punchlist items remain to be fulfilled, however, prior to exhauster " $C$ " being able to be used for flammable gas RMCS operation, and are enumerated herein.

It is appropriate that the scope of the DRC review be understood. The DRC was initially commissioned to conduct design verification activities on the Hydrogen Exhauster Interlock System (HEIS) with "particular emphasis on Safety Class systems, structures, and components and their performance requirements." The scope was later extended to the complete exhauster system, and subsequent to that the HEIS was eliminated as a consequence of the $A B$ change. The DRC added Safety Significant SSCs to its scope in the course of conducting its review. The review scope did not, and does not, include SSCs classified as General Service.

The DRC closed all member RCR comments as of $07 / 29 / 97$. A final verification of the exhauster safety SSCs design against the Design Compliance Matrix (DCM), in effect the design review checklist for the review, was initiated at a meeting of the DRC on $08 / 07 / 97$ and was completed (initialed by responsible DRC members) this morning.

\section{PUNCHLIST ITEMS: (categorical)}

1. The DCM used to conduct the review is a draft document. The DCM for the exhauster will require review/approval/issuance and a subsequent reconciliation check with the draft DCM used during review.

2. The draft $D C M$ is predicated on compliance with $N 509 / N 510$ or with the current N.O.C. The current design complies with neither. Reconciliation requires that the exhauster design be in compliance with one or the other.

3. Procedures used for operation/calibration must reflect control limits established in requirements documents. $D C M$ to $A B$ Compliance Matrix reconciliation check required.

4. Multiple crrors noted in draft DCM with regard to source references and design attributes. These will need to be corrected in approved/issued DCM (for exhauster). 
HNF-2369

Rev. 0

DON'T SAY IT --- Write It!

TO: DH Shuford

S7-01

$\begin{array}{llr}\text { cc: } & \text { RM Boger } & \text { S7-12 } \\ \text { RS Popielarczyk } & \text { S7-01 } \\ \text { GPJ File:DRC-SXPS.DSI }\end{array}$
DATE: $11 / 13 / 97$

FROM: GP Janicek $\quad \$ 7-12$

SUBJECT: Closure of Formal Design Review for RMCS Deployment in SX Farm

The purpose of this DSI is to inform you that, although the formal design review conducted by the Design Review Committee for the RMCS portable exhausters has not been formally closed (owing to required document reconciliations), it IS CLOSED with respect to safety SSCS required for RMCS deployment in SX Tank Farm.

Sampling operations in SX Farm tanks, being actively ventilated, does not require a portable exhauster. Instead, a Safety Class PRESSURE SWITCH (PS) is utilized to monitor tank pressure and cause shutdown of RMCS operations if necessary. This PS underwent formal design review as part of the same review for the portable exhauster, but as a separate activity. (Review DRC-004d of ECN\# 640442 and 640499). All Review Comment Record (RCR) items have been satisfactorily addressed and closed. There are no outstanding checklist items constraining use of the PS.

For your information, Work Package ES-97-501 was supposed to calibrate two pressure switches for eventual RMCS use in $5 X$ Farm. As of this date, I have only seen, and partially closed the CGI form in that WP, for one of those units, i.e., pressure switch VTP-PS-2203-A. 


\section{Janicek, George P}

From:

Sent:

To:

Subject:
Jeffery C Akers

Friday, September 12, 1997 4:32 PM

George P Janicek; Carl E Hanson

Report 029 Revision for Pressure Switch installation

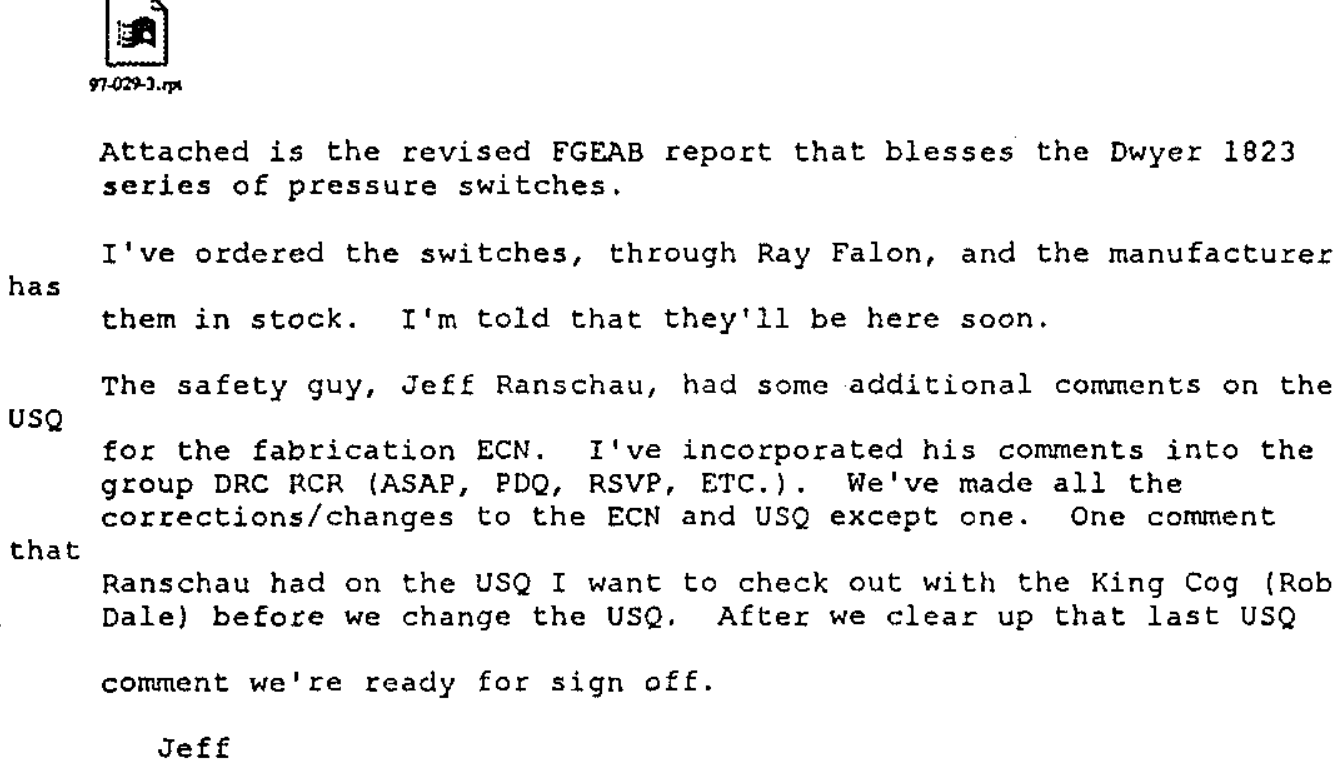

Attached

Dave Smet 


\section{FLAMMABLE GAS EQUIPMENT ADVISORY BOARD INTERPRETATION/RECOMMENDATION REPORT}

Date: September 12. 1997

Report No: FGEAB-97-029, Rev. 3

\begin{tabular}{ll}
\hline Board Members at Hearing: \\
$\begin{array}{ll}\text { R. A. Huckfeldt } & \text { R. L. Schlosser } \\
\text { D. B. Smet } & \text { R. A. Wahlquist } \\
\text { C. C. Scoief III } & \text { J. R. Kriskovich }\end{array}$
\end{tabular}

Requestor/Presenters: J0 Criddle Jr., Jeff Smalley, George Janicek

Problems/Issue Statement: Rotary Mode Core (Truck 4) Drilling Exhauster. Revision 1 addresses the Drill String. Sampler Assembly and Process. Revision 2 corrects wording of Drill String and adds evaluation of the pintle rod to the Sampler Assembly and Process. Revision 3 adds evaluation of the Dwyer of Series 1823 switches.

Equipment/Activity Description: Use of gas sample monitoring equipment in the Air Monitor Corporation cabinet with regard to requirements of Standing Order 97-01. Evaluate the use of the drill string and sampler assembly/process for compliance or equivalence to the Standing Order and $\mathrm{JCO}$.

Applicable Authorization Basis: Standing Order 97-01. Rev. 2 Dated: May 5. 1997

"Flammable Gas/Siurry Growth Unreviewed Safety Question: Justification for Continued Operation for the Tank Fams at the Hanford Site." HNF-SD-WM-JCO-007. Rev. 1

Does Equipment/Activity Comply with the AB Ignition Control Requirements?

[]Yes []No [x]other

If No. Does Equipment/Activity Provide Equivalent Design/Measures/Controls?

$[x]$ Yes [JNo []Other

Explanation/Justification:

The equipment reviewed is illustrated on Air Monitor Corporation drawings W21590AA. Revision 2 and W21590GA. Revision 1. Only the equipment exposed to the sample gas stream is in an ignition control area. All other components within the cabinet are in a non-intrusive area. The following is a description of the equipment:

\section{Masstron Flow Transmitters}

The Masstron (Air Monitor Corporation) flow transmitters FT-1. -2, -3, and -4 have previously been reviewed (FGEAB-97-012) and meet ISC 2 requirements for components exposed to the vapor stream.

4 Vel anmysst foretigasb. r pt 


\section{FLAMMABLE GAS EQUIPMENT ADVISORY BOARD INTERPRETATION/RECOMMENDATION REPORT}

Date: September 12, 1997

Report No: FGEA8.97.029. Rev. 3

Explanation/Justification: (continued)

Veltron Vacuum Transmitter

The veltron is identical to the Masstron except that it uses one less pressure transmitter and somewhat different electronics. All components exposed to the vapor stream meet ISC 2

requirements.

Electric Valves

Solenoid valves FCV -2. -3 . and -4 and ICV- 6 do not have any normally sparking components and electrical components are isolated from the vapor stream. Flow control valve $\mathrm{FCV}-5$ is a motor actuated modulating ball valve. The motor and wiring are not exposed to the vapor stream. All these valves meet ISC 2 requirements for components exposed to the vapor stream.

\section{Pressure Switch}

Pressure switches PS-1 and PS-2 are Dwyer Model 1823-40. The low port is connected to the process vapor and the high port is vented to atmosphere. The electrical switch is isolated from the vapor stream by a diaphragm. The FGEAB has evaluated the $1823 \cdot \mathrm{XX}$ Series switches $(00$ to 80$)$ and has determined that they all meet ISC 2 requirements for use with the vapor stream on the low pressure port side (snap switch on the high pressure or atmosphere side.

Owyer Capsu-Photohel ic Switch/Gage Series 43000 will be used when sampling tanks in the SX Farm to monitor and shutdown upon sensing of tank pressurization. This device meets ISC 2

requirements for Dome Intrusive equipment as all ignition sources within the switch/gage are isolated form the vapor space by the silicon rubber diaphragm.

Vacuum Pump

The EG\&G Rotron Blowers meet Type B Spark Resistant construction intent under AMCA Standard 99 . 0401-86. and thus are evaluated to be compliant with ISC 2 requirements for Dome Intrusive equipment.

\section{Interpretation of Shutdown System Requirements for Dome Intrusive Equjoment}

The FGEAB has been requested to document that. per the current Flammable Gas USQ Authorization Basis. no automatic electrical shutdown system is required for Dome Intrusive equipment that is evaluated to meet ISC 2 controls (normally non-sparking). This clarification specifically addresses gas detection type shutdown systems.

it should also be noted that gas detection systems. per the $A B$. are not allowed to be used as primary ignition control interlocks in Dome Intrusive regions. They are only allowed as primary controls in Ex-Tank regions. This does not preclude them from being used for defense-in-depth configurations. 


\section{FLAMMABLE GAS EQUIPMENT ADVISORY BOARD INTERPRETATION/RECOMMENDATION REPORT}

Date: September 12, 1997

Report No: FGEA8.97-029, Rev. 3

Explanation/Justification: (continued)

RMCS Drill String

Three ignition source modes were evaluated - 1) frictional heating by the waste intruding portion of the string. 2) torsional break of the string in the dome space and 3) mechanical sparks caused by inadvertent impact of carbon steel to carbon steel when assembling or dismanting the drill string in the ex-tank area. The following is the Board's decision for each of these scenarios:

1) The drill string design precludes rotation at greater than $55 \mathrm{rpm}$. The drill string is also purged with nitrogen. which provides additional cooling of waste intrusive region. Tests have shown that this design does not exceed the waste contacting temperature limit of 160 degrees Celsius. This is in compliance with ISC 1.

2) A torsional or shear break of the drill string could occur at its weak point if the drill bit becomes bound in the waste. This has occurred in the past when the Push Mode system was used in the rotary mode. The string's weak point would be at the sectional joint 0 ring grooves somewhere in the middle of the string (highest stress point under this condition). The region within the drill string is nitrogen purged and interlocked. thus meeting ISC I conditions. The criterion for dome space controls rely primarily on normally non-sparking design of which this meets. Under the applied conditions of the drill string. it is a nomaily non-sparking piece of equipment and thus meets ISC 2 requirements.

3) Impact between two non spark-resistant materials when assembling or dismantling the drill string creates no more risk than the acceptable routine handling of any equipment that is made of carbon steel material. Controls for minimizing this risk are routinely installed in the work packages. In this case. it is evaluated that mechanical sparking with sufficient energy to combust hydrogen is not a 'normal use' scenario. but is 'failure' mode and thus compliant with ISC 2. However. due to the proximity of the ISC 1 region (interior of the drill string). the board requires that monitoring for flammable gases be performed at least once per hour during any phase of the assembly or dismantling activities if the drill string has been left in place without purge or inerting gas at hydrostatic head condition. The basis for the on hour comes from SAD-035 andlys is. which establishes a 180 minute time frame before the LFL of flamable gas could actually accumulate within the drill string. 


\section{FLAMMABLE GAS EQUIPMENT ADVISORY BOARD INTERPRETATION/RECOMMENDATION REPORT}

Date: September 12. 1997

Explanation/Justification: (continued)

Sampler Assembly and Process

The sampler assembly is used to obtain and retrieve waste samples. It is mechanically operated and consists primarily of stainless steel components. There may be several carbon steel

components (can't be verified without a destructive test) that actuate in a "snap action" during the sample capture process or may drop due to a single failure:

however. as outlined below. the nitrogen purge system process ensures inerting of the environment inside of the sampler when the sampler is being operated. meeting ISCl requirements.

The steps for operation of the nitrogen purging system for rotary mode core sampling. excluding the z-purge and riser liner purge. starting with connecting the quill rod to comence drilling is as follows:

Note: The configuration of the system would be that the drill string is open ended at the top (ie. the change out assembly has just been removed) and a sampler. with a one way chevron seal. is latched in place in the core barrel. The bottom end of the drill string with the core barrel and bit are embedded in the waste.

1) The core sample truck rotating platform is positioned so that the quill rod is over the open ended drill string and the quill rod is lowered and connected to the drill string.

2) The operator initiates purge gas flow down the drill string by turning on the Purge Gas Isolation Valve and adjusting flow with a needle vaive. The flow is kept to a minimal amount to avoid disturbing the waste. The flow is verified by checking that the pressure in the drill string is at least 0 to $.5 \mathrm{psig}$ above the hydrostatic head pressure that was recorded during recovery of the previous sampler.

3) The operator then lowers the sample actuator (grapple) into the drill string to attach it to the pintle rod on the universal sampler.

4) After the grapple has been lowered the operator starts rotary mode core sampling for the current sample segment by increasing the purge gas flow rate to a minimum of $30 \mathrm{scfm}$ using the needle valve. and initiating drill bit rotation. (note: the purge gas flow rate is measured by redundant turbine flow meters which have a calibrated range of 20 to $130 \mathrm{scfm}$ )

5) When the current sample segment is complete the operator reduces the purge gas flow to a minimal rate using the needle valve while verifying the pressure is at least 0 to .5 psig above the hydrostatic head pressure that was recorded during recovery of the previous sampler.

6) The operator raises the sample actuator into the quill rod which activates the sampler valve closure mechanism. then closes the Purge Gas Isolation valve which 


\section{FLAMMABLE GAS EQUIPMENT ADVISORY BOARD INTERPRETATION/RECOMMENDATION REPORT}

Date: September 12. 1997

Report No: FGEAB-97-029. Rev. 3

Explanation/Justification: (continued)

Switches the Vent Line Isolation valve position to vent the grapple box and the drill string to the tank dome space. (If the upper limit proximity sensor fails to detect the raised position, the grapple will reach the physical stop. disengaging the pintle rod. The pintle rod will drop. impacting the sample chamber or drill string. a potential spark source.)

7) The quill rod is separated from the drill string and the cable spray washer and change out assembly are added (note: the change out assembly is an isolation ball valve that is used to provide containnent of the drill string when the quill rod or shielded receiver is not attached. Also. the change out assembly has a nitrogen addition port below the isolation valve that is used to provide hydrostatic head gas to the drill string during sampler change out). The Pressurized Drill String line is attached to the change out assembly, the Pressurize Orill String isolation valve is turned on. and the Orill String Hydrostatic Head Flow ball valve is opened which initiates flow through the change out assembly. down the drill string. and out the face of the bit at approximately .3 to 8 scfm.

8) The rotating platform is positioned so that the shielded receiver assembly is positioned over the change out assembly and the shielded receiver is lowered and attached to the change out assembly.

9) The shielded receiver ball valve is opened (note: this valve is used to maintain containment of the shielded receiver and sampler hoist box when the shielded receiver is not connected to the drill string) and the Pressurize Shielded Receiver Isolation valve is turned on. The shielded Receiver Hydrostatic Head Flow ball valve is opened which initiates flow into the sampler hoist box and shielded receiver at approximately 0.3 to 8 scfm.

10) When the pressure in the shielded receiver equals the pressure in the drill string. the change out assembly valve is opened and the remote latch unit lowered to

11) The remote latch unit with the sampier attached is raised into the shielded receiver and the change out assembly vaive is closed (note: the drill string still has nitrogen flow from the Pressurize Drill String line).

12) The Pressurize Shielded Receiver Isolation valve is turned off which vents the sampler hoist box and shielded receiver to tank dome space through the Vent Isolation valve.

13) The shielded receiver ball valve is closed. the shielded receiver is disconnected from the change out assembly. the rotating platform is positioned to deposit the sampler a cask and a pick up new sampler.

14) The rotating platform is positioned so that the shielded recciver assembly is positioned over the change out assembly and the shielded receiver is lowered and attached to the

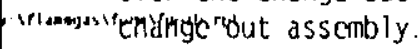




\section{FLAMMABLE GAS EQUIPMENT ADVISORY BOARD INTERPRETATION/RECOMMENDATION REPORT}

Date: September 12, 1997

Report No: FGEAB-97-029. Rev. 3

Explanation/Justification: (continued)

15) The shieided receiver ball valve is opened and the Pressurize Shielded Receiver Isolation valve is turned on and fiow is established in the sampler hoist box and shielded receiver at approximately .3 to $8 \mathrm{scfm}$.

16) When the pressure in the shielded receiver equals the pressure in the drill string. the change out assembly valve is opened and the remote latch unit lowered to deposit the new sampler.

17) The remote latch unit without the sampler attached is raised into the shielded receiver and the change out assembly valve is closed.

18) The Pressurize Shielded Receiver Isolation valve and Pressurize Drill String Isolation valve are turned off which vents the sampler hoist box and shielded receiver to tank dome space through the vent Isolation valve.

19) The Crossover Vent Isolation ball valve is opened which allows the Pressurize Drill String line to vent to the tank dome space.

20) The shielded receiver ball valve is closed and the shielded receiver is disconnected from the change out assembly.

21) The change out assembly and cable spray washer are removed from the drill string and a new 19 inch section of drill rod is added.

22) The process is then repeated from step 1.

If Not Equivalent. What Changes are Necessary to Comply or Provide Equivalency?

FGEAB INTERPRETATION/RECOMMENOATION:

\begin{tabular}{|c|c|c|c|c|c|}
\hline $\begin{array}{c}\text { Equipment. Materials } \\
\& \text { Work Practices } \\
\text { (1) }\end{array}$ & $\begin{array}{l}\text { Location } \\
\text { (2) }\end{array}$ & $\begin{array}{l}\text { Ignition } \\
\text { Control } \\
\text { Set } \\
\text { (3) }\end{array}$ & $\begin{array}{l}1 C \text { Set } \\
\text { Met } \\
\text { (4) }\end{array}$ & $\begin{array}{l}\text { FGEAB Sofety } \\
\text { Equivalence } \\
\text { Ruling } \\
\text { (5) }\end{array}$ & $\begin{array}{l}\text { Approved } \\
\text { Exception } \\
\text { (ध) }\end{array}$ \\
\hline $\begin{array}{l}\text { Masstron Flow } \\
\text { Transmitter }\end{array}$ & $\begin{array}{c}\text { Dome } \\
\text { Intrusive }\end{array}$ & ISC 2 & No & $\begin{array}{c}\text { Yes } \\
\text { FGEAB-97-012 }\end{array}$ & \\
\hline $\begin{array}{l}\text { Veltron Vacuum } \\
\text { Transmitter }\end{array}$ & $\begin{array}{c}\text { Dome } \\
\text { Intrusive }\end{array}$ & ISC 2 & No & Yes & \\
\hline Electric Valves & $\begin{array}{c}\text { Dome } \\
\text { Intrusive }\end{array}$ & ISC 2 & No & Yes & \\
\hline
\end{tabular}

Page $5.7-10$ 


\section{FLAMMABLE GAS EQUIPMENT ADVISORY BOARD INTERPRETATION/RECOMMENDATION REPORT}

Date: September 12, 1997

Report No: FGEAB-97-029. Rev. 3 
HNF-2369

Rev 0

\section{FLAMMABLE GAS EQUIPMENT ADVISORY BOARD INTERPRETATION/RECOMMENDATION REPORT}

Oate: September 12, 1997

Report No: FGEAB-97-029, Rev. 3

FGEAB INTERPRETATION/RECOMMENDATION: (continued)

\begin{tabular}{|c|c|c|c|c|c|}
\hline $\begin{array}{l}\text { Equipment. Materials } \\
\text { \& Work Practices } \\
\text { (1) }\end{array}$ & $\begin{array}{l}\text { Location } \\
\text { (2) }\end{array}$ & $\begin{array}{l}\text { Ignition } \\
\text { Control } \\
\text { Set } \\
\text { (3) }\end{array}$ & $\begin{array}{l}\text { IC Set } \\
\text { Met } \\
\text { (4) }\end{array}$ & $\begin{array}{l}\text { FGEAd Safety } \\
\text { Equivalence } \\
\text { Ruling } \\
\text { (5) }\end{array}$ & $\begin{array}{l}\text { Approved } \\
\text { Exception } \\
\text { (6) }\end{array}$ \\
\hline $\begin{array}{l}\text { Pressure Switches } \\
\text { Dwyer 1823-xx Series } \\
(00 \text { to } 80) \text { : Dwyer } \\
\text { Capsu-Photohelic } \\
\text { Series } 43000\end{array}$ & $\begin{array}{c}\text { Dome } \\
\text { Intrusive }\end{array}$ & ISC 2 & No & Yes & \\
\hline $\begin{array}{c}\text { Vacuum Pumps } \\
\text { EG\&G EN } 523 \text { Rotron } \\
\text { Blower }\end{array}$ & $\begin{array}{c}\text { Dome } \\
\text { Intrusive }\end{array}$ & ISC 2 & Yes & N/A & \\
\hline RMCS Drill String & $\begin{array}{l}\text { Waste } \\
\text { Intrusive } \\
\text { Dome Space } \\
\text { Ex-Tank }\end{array}$ & $\begin{array}{l}\text { ISC } 1 \\
\text { ISC2 } \\
\text { ISC } 2\end{array}$ & $\begin{array}{l}\text { Yes } \\
\text { Yes } \\
\text { Yes }\end{array}$ & $\begin{array}{l}\text { N/A } \\
\text { N/A } \\
\text { N/A }\end{array}$ & \\
\hline $\begin{array}{l}\text { Sampler } \\
\text { Assembly/Process }\end{array}$ & $\begin{array}{l}\text { Waste } \\
\text { Intrusive }\end{array}$ & ISCI & Yes & $N / A$ & \\
\hline
\end{tabular}

General Application of Finding, If Any:

FGEAB Representative: R.L. Schlosser Date: 9-12-97

Reviewer Signature: $\quad$ D. B. Smet Date: $\underline{9-12-97}$ 
HNF-2369

Rev. 0

Janicek, George P

From:

Sent:

To:

Cc:

Subject:
George P Janicek

Tuesday, September 30, 1997 1:56 PM

Theodore D Jarecki; Nancy J Milliken; C C III (Chuck) Scaief; Michael L McElroy; J A (Jeff)

Ranschau; James R Kriskovich

George $P$ Janicek

ECN 642991 (640442) Revision

DRC members,

The subject ECN we recently reviewed (DRC Review Meeting of $09 / 10 / 97)$

this

in draft form as $\# 642991$ and approved as $\# 640442$. As a reminder,

ECN changed out the waste tank pressure switch for sampling operations

the

in SX farm. It turns out that some of the parts required to mount

PS are difficult to obtain or obtain in a timely fashion.

Therefore a

Change ECN, \#640499, was written to enable using fasteners and MCElroy.

connectors CPO has on hand in order to expedite fabrication.

Ranschau, and I have reviewed and approved the change ECN in our individual capacities. The remainder of you I could not reach by phone today to obtain a beforehand OK to approve the ECN as DRC chairman. I believe that to be necessary due to the initial ECN and having undergone formal design review. In any case, I went ahead

a

approved the ECN and am asking for your OK after the fact. Either your

if

positive response or a non-response to this message will indicate

approval of my action. Also, a copy of the change ECN is available

you want one for your files.

Thanks,

GPJ 
HNF-2369

Rev. 0

DON'T SAY IT --- Write It!

TO: DH Shuford

S7-01

cc:

$\begin{array}{ll}\text { RM Boger } & 57-12 \\ \text { JE Corbett } & 57-01 \\ \text { JC Criddle } & 57-12 \\ \text { CE Hanson } & 57-12 \\ \text { JR Kriskovich } & \text { RI-56 } \\ \text { RS Popielarczyk } & 57-01 \\ \text { JS Schofield } & 57-12\end{array}$

DATE: $03 / 27 / 98$

FROM: GP Janicek

$\$ 7-12$

Telephone: $376-2225$

SUBJECT: Exhauster "C" Formal Design Review / NOC Reconciliation

REFERENCE: DSI, GP Janicek to DH Shuford, "Closure of Exhauster "C" Formal Design Review", dated 08/08/97.

A meeting was held on Monday, March 23, 1998 to ascertain if the recently approved Notice of Construction (No. NWP 95-RMCS(3)), for RMCS had changed in any way the basis for the Exhauster " $C$ " formal design review as presented in the Design Compliance Matrix (DCM) checklist used for the review. Meeting attendees included Mssrs. JC Criddle, CE Hanson, JR Kriskovich, and myself. It was agreed that the $D C M$ and NOC were fully reconciled.

The reference DSI had originally informed you that the formal design review was closed pending completion of four (4) punchlist items. Items \#1 and \#4 of that punchlist had to do with assuring that the final approved DCM was reconciled with the "draft" version used during the review. This was accomplished during the review and approval of the document (HNF-SD-WM-CR-062, BASELINE DESIGN COMPLIANCE MATRIX FOR THE RMCS SYSTEM), issued December 12, 1997. Item \#2 of the punchlist had to do with reconciliation of the DCM with N509/N510/NOC and was accomplished in conjunction with the meeting described above. Punchlist item \#3 had to do with ensuring that the $A B$ control limits, incorporated in the DCM and used as part of the basis for review, were indeed implemented. My understanding is that this will be accomplished by the $A B$ Compliance Matrix which is item \#1 on a separate readiness checklist for Exhauster " $C$ " which you are maintaining.

In conclusion, as chairman of the design review committee, I consider the formal design review for Exhauster "C" closed. I have a remaining responsibility to issue a Design Review Report (HNF-2369), and hope to accomplish this in the very near future.

If you have any questions, please call me.

Thank you.

GP Janicek 
$N 4 H<D$

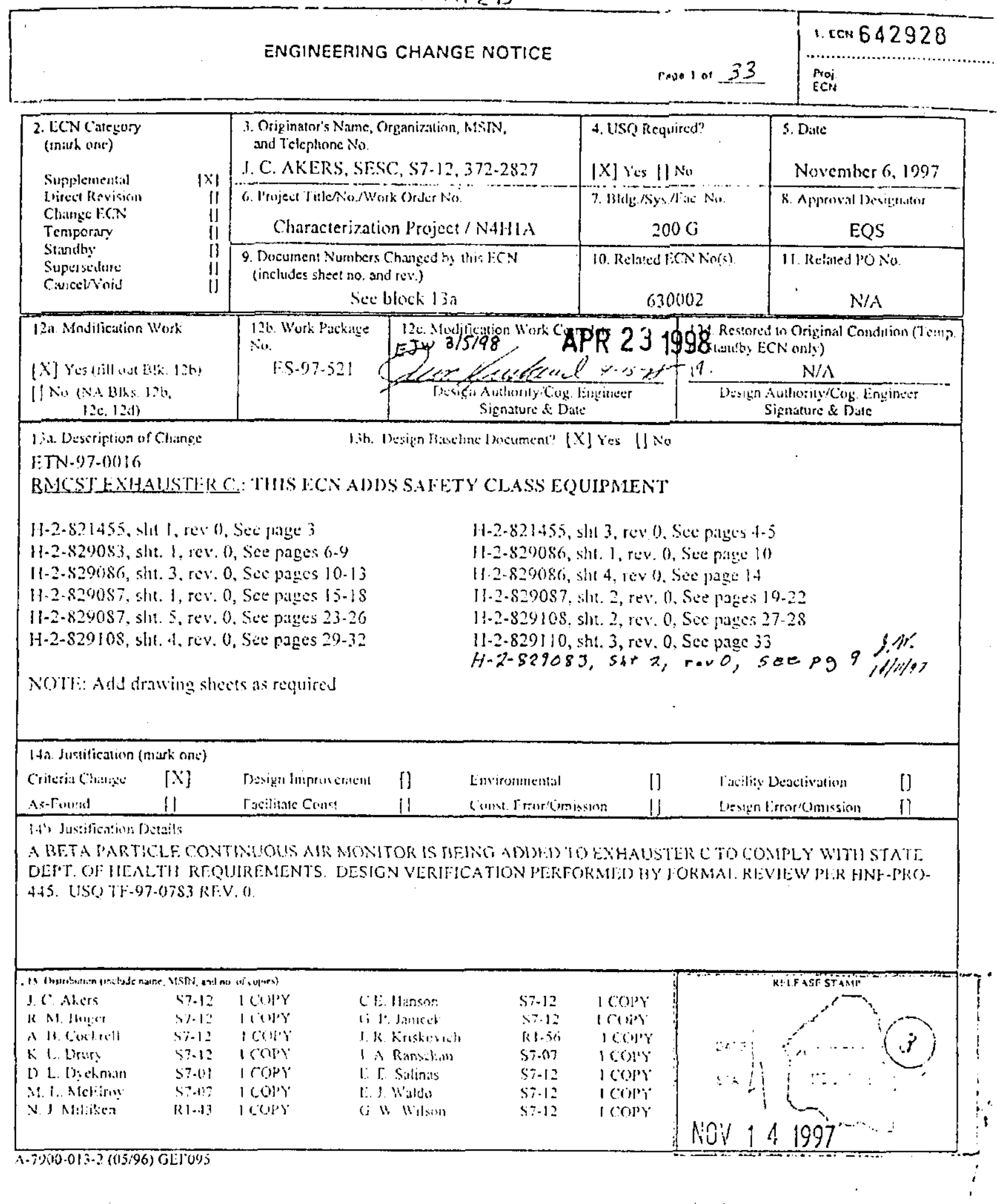




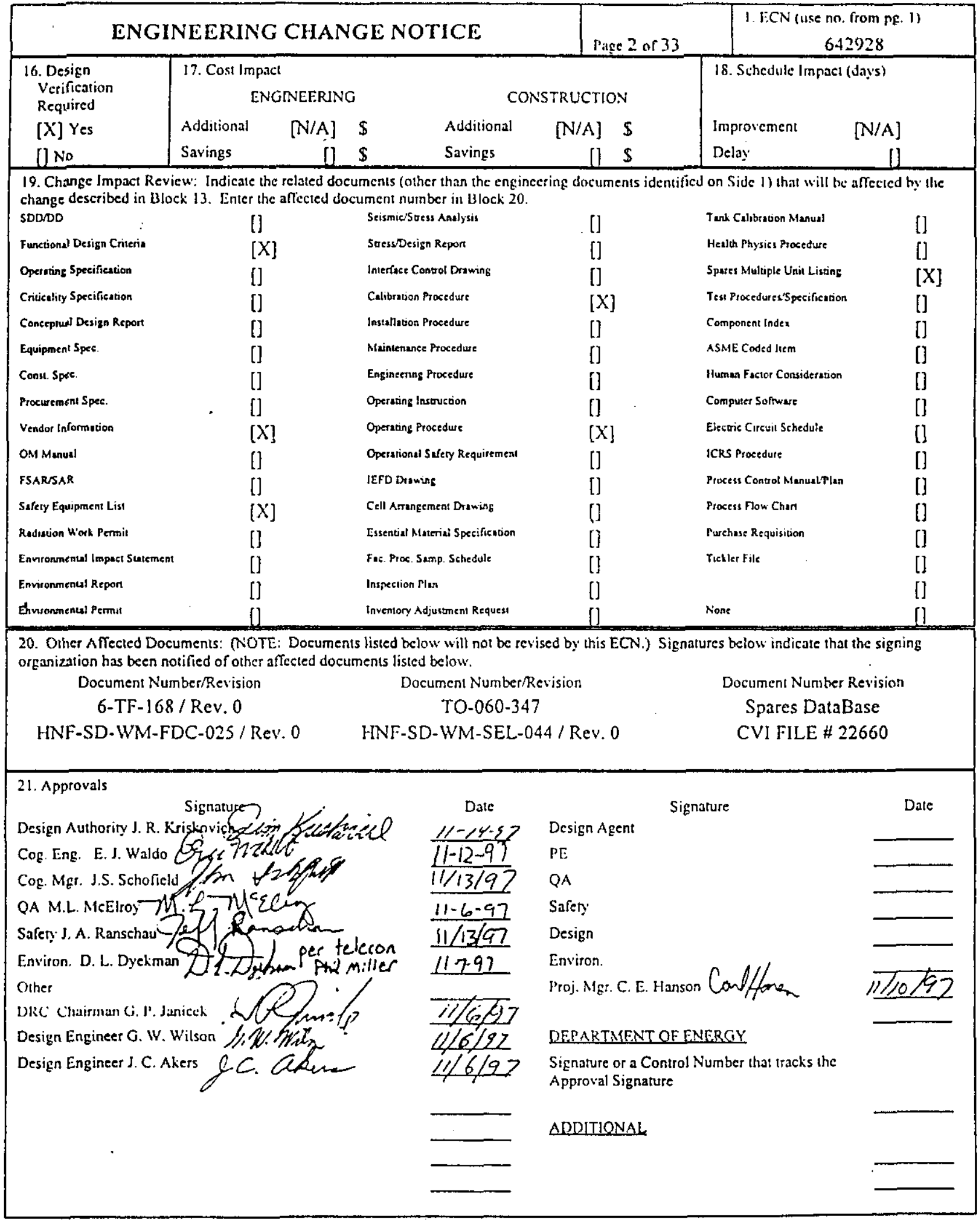

\footnotetext{
A-7900-013-3(05/96) GEF096
} 